Historic, Archive Document

Do not assume content reflects current scientific knowledge, policies, or practices. 



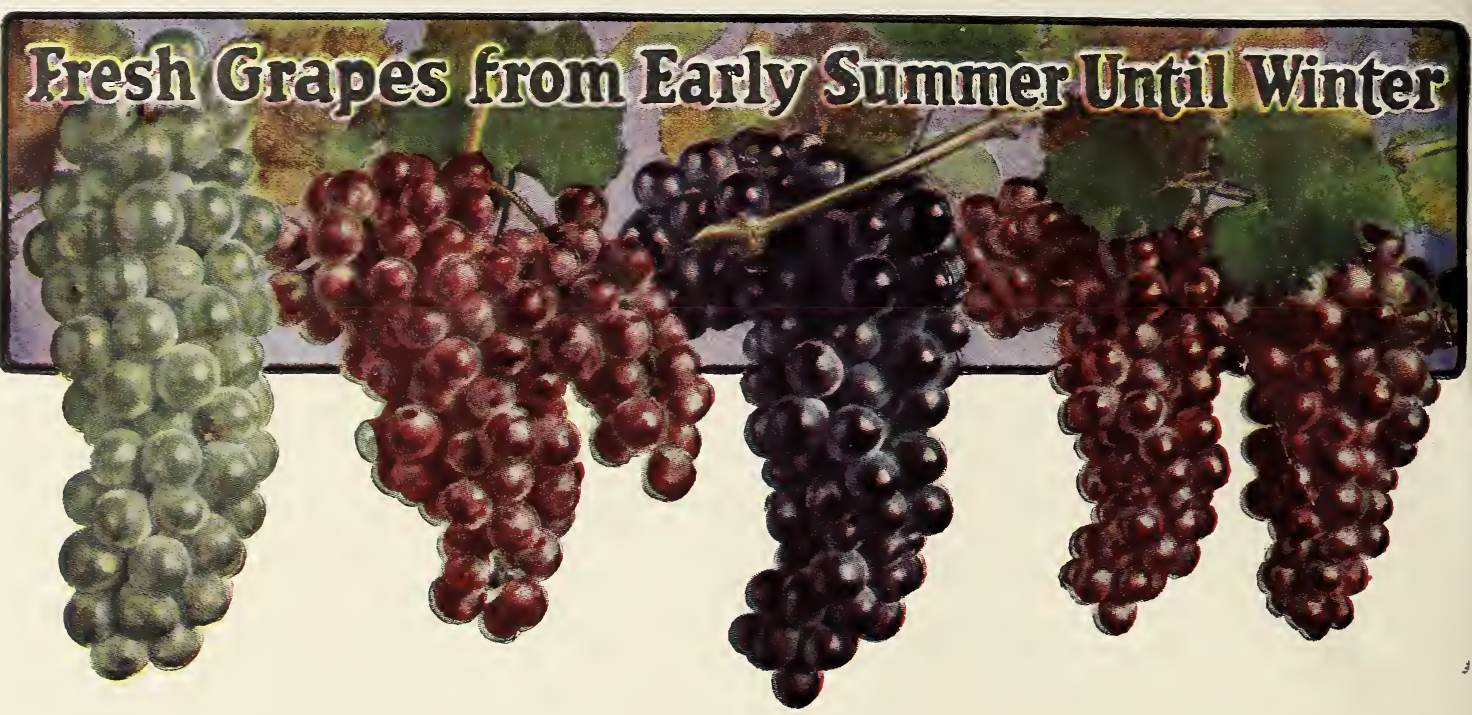

\section{Big Bargains in Grape Vines-See these Prices}

Four Choice Grape Vines (your selection of rarieties) $\$ 1.00$; 10 Choice Vines (one of each kind, or your selection of varieties) $\$ 2.00$; $2 \tilde{0}$ for $\$ 1.50 ; \tilde{0}$ for $\$ 8.00 ; 100$ for $\$ 15.00$, delivered, prepaid, anywhere in the United States.

The Grape is one of the easiest fruits to grow. There is scarcely a country or city yard or garden so small that space cannot be found to plant one or more Grape Vines. Grapes will thrive anywhere, in any climate or soil. Will do well on soil too poor to raise a crop of grain or other fruit. A Grape vineyard represents a permanent investment that will pay big dividends every year for a lifetime. We have a fine stock of the following varieties:

AGAWAM. Dark red; large bunch and berry; rich, sweet, aromatic flavor. Ripens closely following Concord. An excellent keeper that may be kept in common storage until January. 3ãc each, postpaid.

BRIGHTON. Sweet and delicious red Grape. Should be grown in every home garden. Not generally recommended as a commercial variety, as it will not ship to distant markets. Vigorous; productive; ripens two weeks ahead of Concord. 35c each, postpaid.

CAMPBELL's EARLX. Black, with purple bloom; large bunch and berry. Juicy, with rich, sweet flavor; hardy; vigorous. Two weeks earlier than Concord. Fruit hangs on vines sound and perfect for ten weeks or more after ripening. 35. each, postpaid.

CATAVIB. Purplish red, bunch large, berries of medium size; rich vinous flavor, of best auality for table and e. Late; ripens here the last oì September. The best keeper, lasting until March or later. 35c each, postpaid. ost widely grown variety. A large, blue-black Grape, ripening about the middle of September in and year

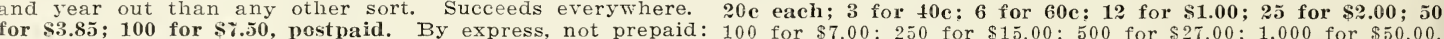

DELATIRE is the small, red Grape shown above. No American Grape has more delicate flavor or more pleasing aroma. Ripens with Concord. Brings from 50 to 100 per cent more on the market than other varieties. A hardy, igorous vine; succeeds both North and South. 3ac each, postpaid.

MOORE'S DIAMOND. The best early white Grape for the home garden. ripening about a week before Niagara, White, with rich yellow tinge; unsurpassed in quality and beauty; sweet, juicy, few seeds. Vine hardy, vigorous and productive. 35c each, postpaid.

MOORE'S EARLY. Similar but larger than Concord and ripens 2 or 3 weeks earlier, the last fruits of it being sent to market before those of the Concord are picked. Vines hardy, vigorous and moderately productive. Its size and earliness make it desirable for early market and home use. 35e each, postpaid.

NIAGARA. The leading white Grape throughout the country. Ranlis with Concord in vigor and productiveness, and ripens at the same time. Bunch and berry large and handsome. Tender, sweet, juicy and excellent flavor. 35c each, postpaid.

WORDEx. Larger berries and bunches than Concord, sweeter, better quality and ripens a week earlier. Fine for the local market and the home garden, but not a good shipper on account of its thin skin. 35c each, postpaid.

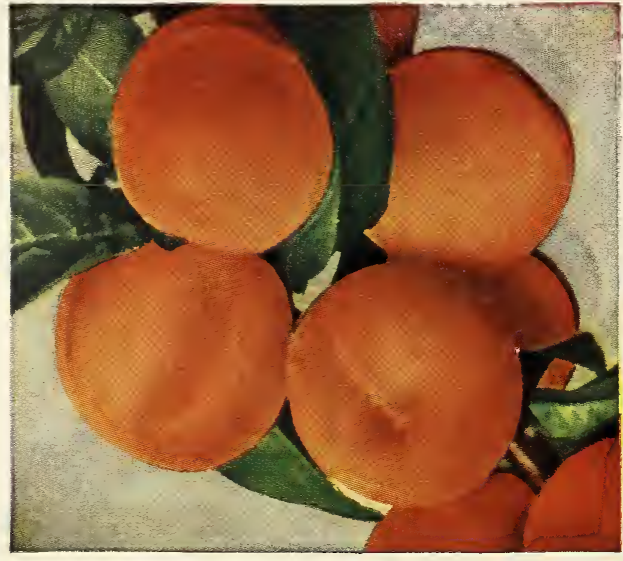

Superb Apricot

\section{Hardy Superb Apricot}

Highly Ornamental and Valuable Fruit Tree

Superb is a hardy Russian variety, the best flavored and the most productive hardy Apricot. The fruit ripens a month earlier than early Peaches. As hardy as the hardiest Peach, and usually begins to bear two years after planting. It is very productive. In shape and color it resembles the Peach, but in texture and smoothness of its skin, it is more like the plum. The Superb has a most delicious flavor and, in addition to being very desirable for eating fresh, is much prized for canning and drying. The Apricot is a delightful addition to any home planting. not only because of the delicious rruit, but for the exquisite beauty of the blossoms. Considered as an ornamental tree alone, the Apricot is unsurpassed.

Our fine, large, thrifty, Northern grown Apricot trees are budded on plum roots and are much hardier than Southern grown stock and are longer lived than Apricots that are budded on peach. Trees grown as we produce them may cost you a little more, but they are the best for both the North and the South. We cannot ship Apricot
trees to Arizona, California, Idaho, Oregon, Washington, or Canada. PRICES: By express. not propaid. \$1.00 each; 3 for \$2.75; 5 for $\$ 4.25$; or 10 or more at 80 e each. 


\section{Burgess' Seed and Nursery Book for 1929}

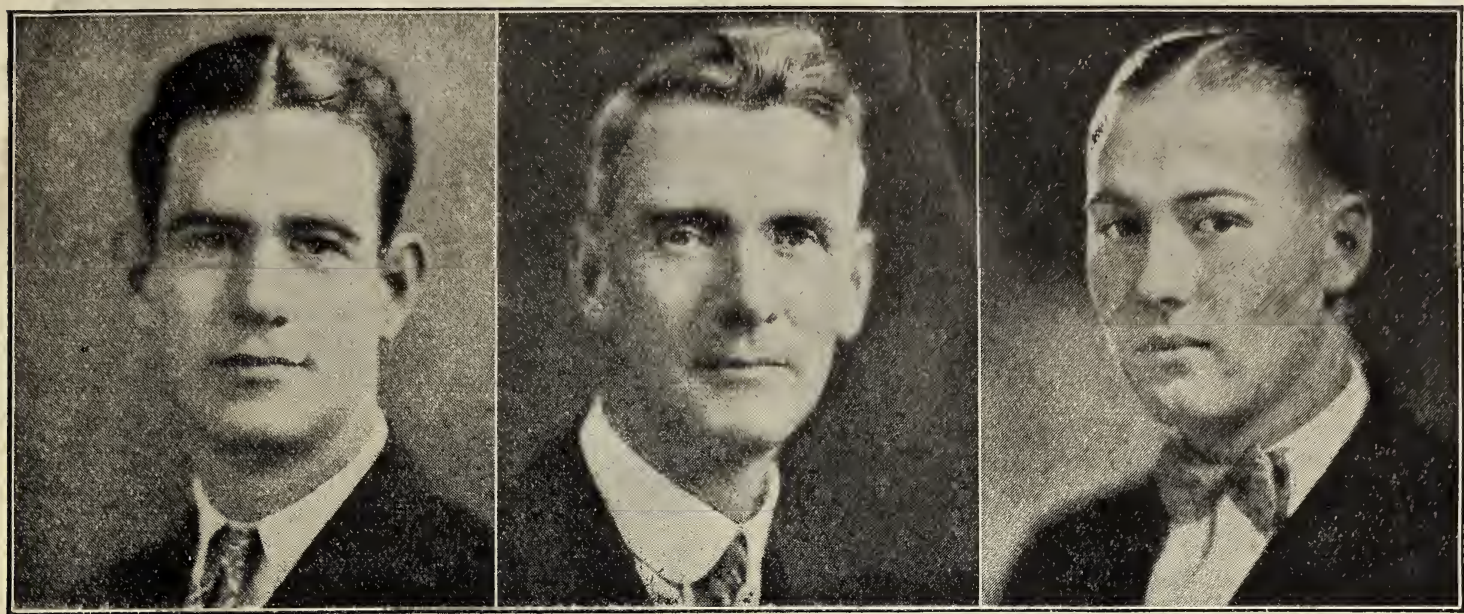

E. H. BURGESS

H. W. BURGESS

D. E. BURGESS

\section{The Burgess Guarantee of Satisfaction}

We positively guarantee all seeds and plants sold by us to be exactly as described in this catalog, and free from disease and insect pests. We also guarantee them true-to-name, and will replace, free of charge, any that may prove otherwise through a possible error.

While we guarantee all seeds and plants to reach you in good growing condition, we do not guarantee crop, and cannot be held responsible if later the plants fail. The life of a plant after it reaches the planter in good condition depends entirely upon conditions over which we have no control. A tree, shrub or other plant is a living organism, as much as a cow, horse or man. It breathes, drinks and feeds, and is subject to attacks of disease and insects. Even with Burgess' superior quality seeds and plants, success depends largely upon cultivation, soil and weather conditions, so it is therefore agreed that in no case shall the Burgess Seed \& Plant Co. be liable for more than the original purchase price.

\section{What Our Bankers Say About Us}

Galesburg State Bank Galesburg,Michigan

November 12,1926

To Whom 1t May Concern.

We take pleasure in stating that the Burgess seed plant co. We valued depositors of ours and with whom wo have Plant co. are valued depositors or ours and fourteen years. had pleasent business deallngs for the past rourtean yoars. No one need hesitate about sending money to them, apright and stralghtforward in all their dealings.

GATBSBURG STATB BANR

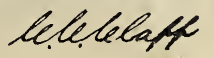

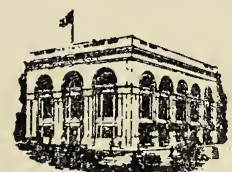

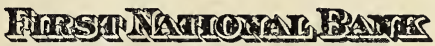

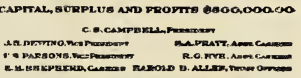

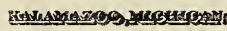

November 8, 1926
To thon It May Concern:

Ve are pleased to ats te that the Burgeas Seed \& Plant Co. of Galesburg, Michigan las carried a very eetiofactory account with ue during tho psot three years. Iho manegement 10 capablo and conoervative. They are well financod and 1 . vublic.

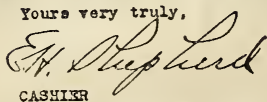




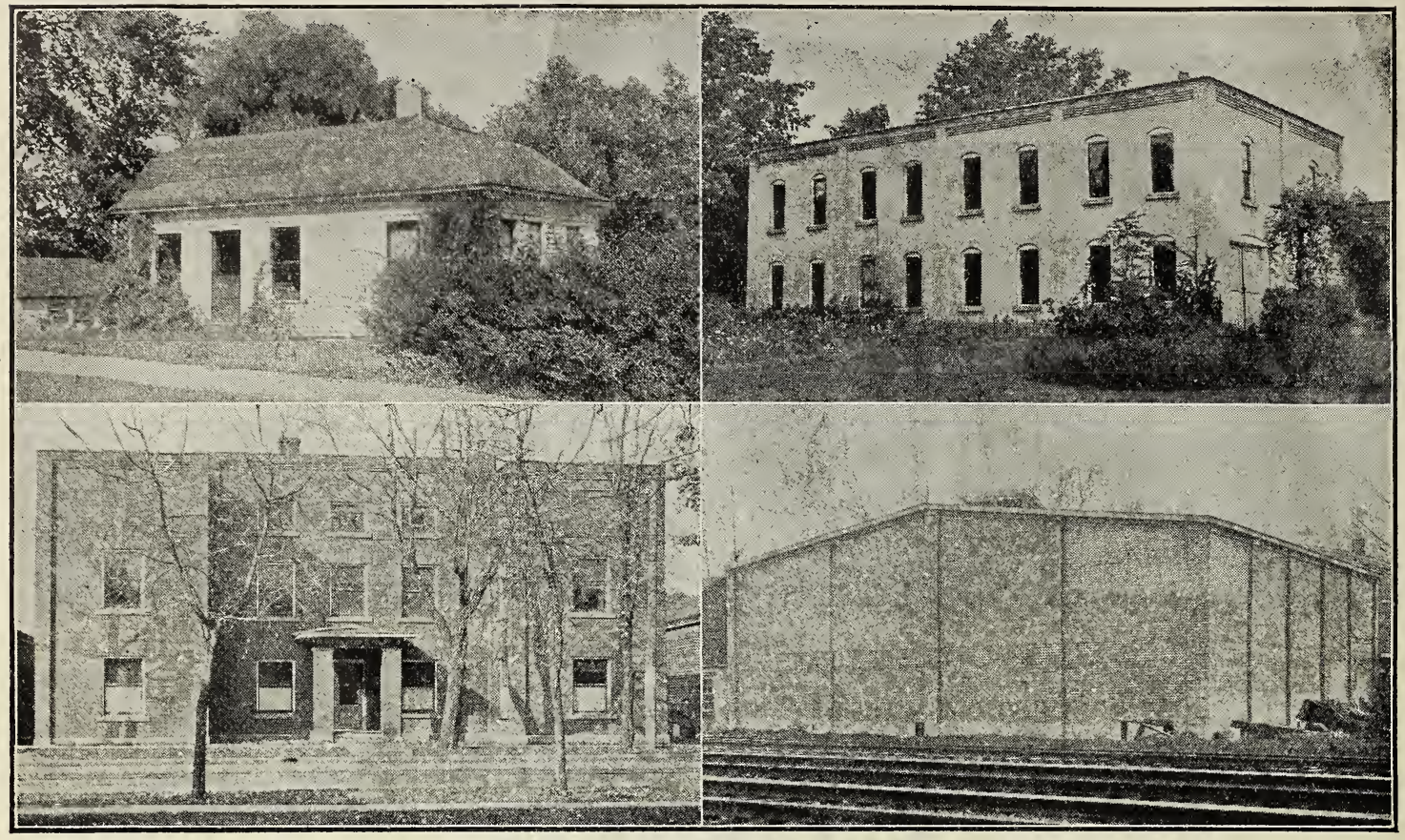

The buildings shown above will give you some idea of the rapid growth of the Burgess Seed and Plant Co. The first year our business was transacted from a room in our residence. The following season we put up seed house No. 1, the small building shown in the above upper left hand corner. Outgrowing these small quarters, we built seed house No. 2, as shown in the above upper right hand corner. Seed house No. 1 is now used for storing rare and choice varieties of flower seeds; and No. 2 for storing vegetable seeds. Five years ago we erected the up-to-date building shown in the lower left hand corner, which covers an entire village lot, $60 \times 185$ feet. Our offices are located in this building, and from this building all our seed orders are filled. The photograph in the lower right hand corner shows one end of our new plant storage, which accommodates a good many car loads of nursery stock. The phenomenal growth of our business has been due to the quality of our seeds and plants and the good service we have given our customers.

\section{We Pay the Postage, Express or Freight}

to your town (anywhere in the world), no matter where you live, on all seeds offered in this catalog, except those offered at our Market Gardener's Wholesale prices, as shown on pages 76, 77 and 78 . We deliver Prepaid, anywhere in the United States, all plants offered in this catalog except where otherwise stated.

Burgess' seeds are sold direct to the planter and not through local dealers. It has been our aim to insure that our customers sow only the best seeds obtainable. With that aim in view you can readily see the necessity of our dealing direct with the gardener. We have more than half a million satisfied customers.

OUR NURSERY, GREENHOUSES and SEED DEPARTMENT are entirely separate. Many customers prefer having their seeds shipped early, their bedding plants late, with the fruit and ornamental section in season between. Even when this arrangement is not specified, we sometimes thus exercise our discretion, for the customer's best interests.

ALWAYS SEND REMITTANCE WITH ORDER. Our terms are the same to all Our business is done on a cash basis. This is a direct benefit to all our customers, as we are not compelled to increase our selling price to you in order to cover other people's bad debts, and at our low prices we can't afford to open any accounts or fill C. O. D. orders. While we prefer that remittance be made either by post office or express money order, bank draft or registered letter, we will, for amounts of less than one dollar, accept clean postage stamps.

REMEMBER-We cannot accept Canadian or foreign postage stamps, as we cannot use them.

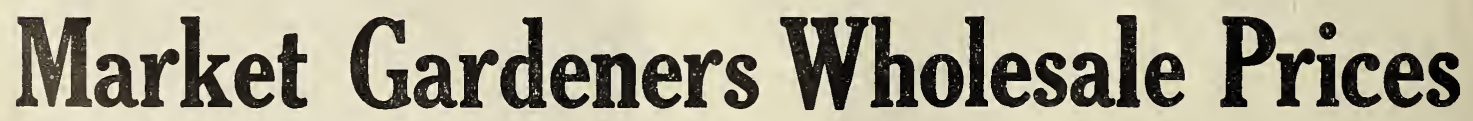

If you can use 10 pounds of seed (a total of ten pounds of all kinds combined) you are entitled to our Market Gardeners' Wholesale Prices. Read about it on page 76. Notice wholesale prices on pages 76, 77, and 78. 


\section{Burgess' Hardy Vegetable Seeds are the Best for All Climates}

The home-gardener and the commercial grower will find in our Vegetable Seed Department a list of the most dependable varieties - the best of both the old and new sorts. We do not offer as many varieties as some seedseasy by describing accurately and telling both the advantages and disadvantages of each sort.

The best test of a seed is the crop it produces. Burgess' Hardy Michigan Seeds have no superior.

We are supplying many of the most critical market-gardeners, in every State in the Union, with the best and purest strains of Vegetable Seeds. The steady increase in our market-garden trade each year, and the fact that the gardeners who began buying from us when we first started in business are still numbered among our. best customers, is the best evidence that our seeds give satisfaction.

\section{Asparagus}

An onnce of good seed will produce about 250 plants; 2 lbs. for one acre.

GIANT WASHINGTON. A new variety developed by the United States Department of Agriculture. A rapid growing sort with a delicious flavor and tenderness, yielding stalks two inches in diameter, and even when twelve inches long are perfectly tender. Our giant Washington Asparagus is the Mary Washington strain. It is practically immune to "rust" and other Asparagus diseases and, is, without doubt, the finest strain of Asparagus now available. Pkt., 10c; oz., 20c; $1 / 4$ lb., 60c; lb., \$2.00, postpaid.

PALMETTO. Another excellent variety and, with the exception of Giant Washington. is the nearest rust proof of any. It is a wonderful yielder, producing large. thick, dark green shoots, nearly as large as Giant Washington. Pkt., 5c; oz., 10c; $1 / 4$ lb., 25c; lb., 75c, postpaid.

\section{Prices of Giant Washington Asparagus Plants}

Last season we sold more plants of our Mary Washington strain of Giant Washington Asparagus than of all other varieties combined. We consider this was due entirely to the superior quality of this variety, and for that reason we have discontinued the growing of all other sorts.

The plants we have to offer are choice one-year-old plants. We always recommend one-year-old Asparagus plants, for in addition to costing less money than two-year-old plants they are the best size for transplanting.

12 for $30 \mathrm{c}$; 25 for $50 \mathrm{c}$; 50 for $80 \mathrm{c} ; 100$ for $\$ 1.50 ; 250$ for $\$ 3.50$, by parcel post, postpaid. By express, not prepaid, 500 for $\$ 5.50 ; 1,000$ for $\$ 10.00 ; 5,000$ for $\$ 15.00$.

CCLTCRE. Dig or plow trench 15 or 18 inches deep, cover bottom with wellrotted manure, and cover manure with 2 or 3 inches of soil. Place your plants 18 inches apart, spread out roots and cover the plants with 4 inches of good Eoil. Do not fill up trench right away. Fill gradually, as the sprouts come through, until they have grown to the top of the trench. For best results, do not cut until after the second sear. Asparagus grows better and produces earlier in the spring if planted in well-drained soil having a southern exposure.

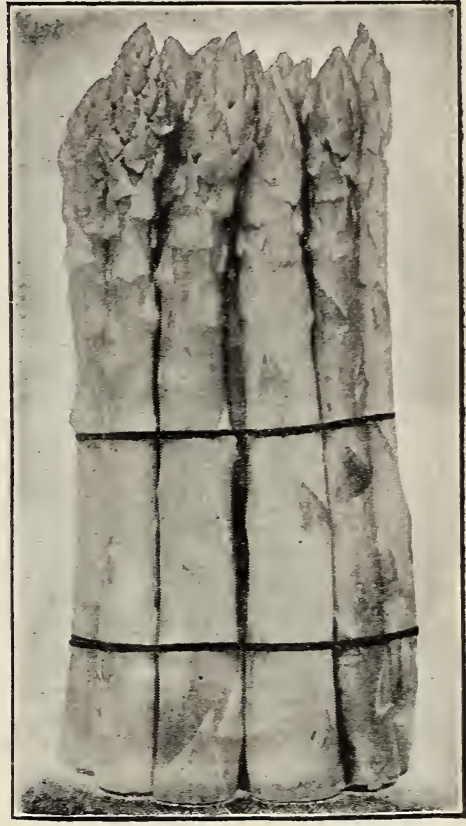

Giant Washington Asparagus

\section{Broccoli, or Hardy Cauliflower}

One ounce will produce about 1500 plants

This is a vegetable very similar to Cauliflower, but hardier and more easily grown. so will be found very raluable in sections where the Caulifower does not do well. Cultivate and use same as Cauliflower.

EARLY PURPLE CAPE. Heads of medium to large size, creamy-white, tinged with purple; delicate flavor. Pkt., 10c; 3 pkts., 25c; oz., i5c, postpaid.

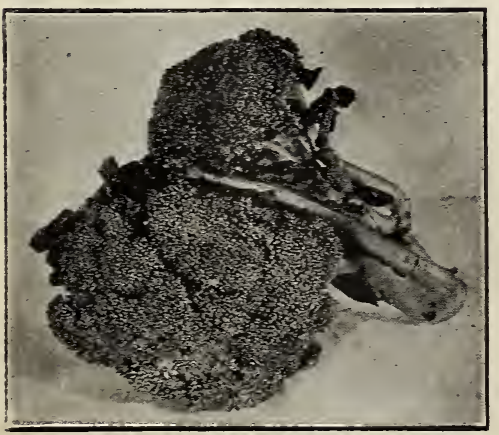

Earì Purple Cape Broccoli
ITALLAX EARLY SPROLTING. A very useful variety recently introduced from Europe. It is quite distinct from other varieties, the sprouting branches having loose heads which are broken off and cooked like Cauliflower. Brussels Sprouts or Asparagus. It is used without blanching and is ready for use as soon as fully developed. After the central head is removed the plant produces many branches, each bearing smaller terminal and lateral heads which are fully as desirable as the first head produced. If these heads are gathered as soon as they become large enough for use, the plant will continue to produce for a period of eight to ten weeks. The long bearing period makes this a rery economical vegetable to grow. The quality is fully equal to Cauliflower and by some is considered superior. It is adapted to growing in spring, summer or fall, and is certainly much more easily and successiully grown in the Northern States than Cauliflower. Sow seed in the spring and harvest sprouts during the summer and fall; or sown in the fall, it will sprout up in the early spring like Asparagus. Pkt., 10c; 3 pkts., 25c; oz., i5c; 1/4 lb., \$2.25, postpaid.

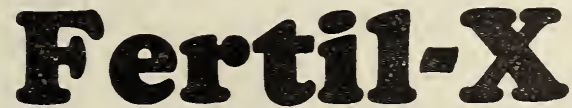
crops, berry busbes, and fruit trees increase production, and improve the quality of the fruits and vegetables. See page 74. 


\section{Burgess' Michigan Grown Beans}

Every seedsman now concedes that Michigan Grown Beans are the best that can be proauced. Our stock of seed is selected with extreme care, and the growing crops carefully rogued several times each season. The following list comprises the best of their respective types.

\section{DWARF WAX-PODDED BEANS}

One pound of seed for 75 feet of row

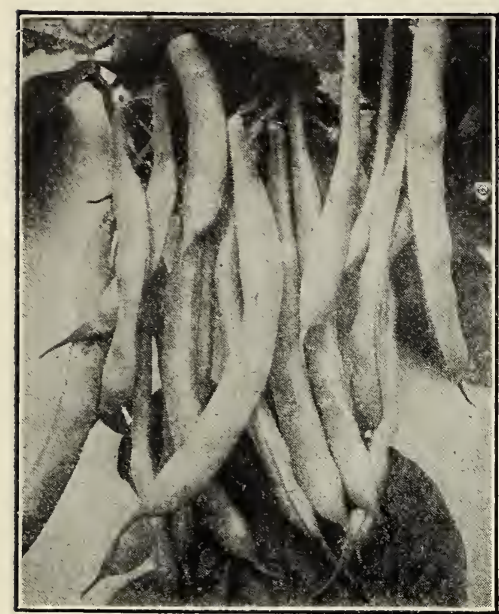

Early Wonder Wax

MPROVED GOLDEN WAX. Medium-early; heavy cropper; pods of good length, oval and quite thick; clear, waxy, golden yellow color, and fine buttery flavor. Pkt., 10c; $1 / 2$ lb., 22c; lb., $40 \mathrm{c} ; 2$ lbs., 70c, postpaid.

UNRIVALLED WAX. Early and very productive. Plants of medium size, robust and very resistant to disease; rich

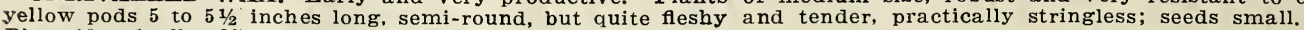
Pkt., 10c; $1 / 2$ lb., 25c; lb., 45̃c; 2 lbs., 80c, postpaid.

\section{Early Wonder Wax}

\section{EARLIEST WAX BEAN-RUST PROOF}

Farly Wonder Wax belongs to the oval podded class and grows a strong plant, 18 inches high and 2 feet across. It is well loaded with pods, 5 to 7 inches long; flat, plump, handsome and meaty, of a clear, waxy yellow color. As to quality the pods are tender, brittle and of fine texture. This is the earliest wax-podded bean; ready to pick in 35 to 40 days. Practically rust-proof; a bountiful yielder, in bearing for a long season; an ideal bean for the home garden and a real money maker for the market gardener. Pkt., 10c; $1 / 2$ lb., 25c; lb., 45c; 2 lbs., 80c, postpaid.

DAVIS WHITE WAX. Medium-early. Eating quality not quite as good as some other varieties, but will bring a better price on the market, owing to its fine appearance. Pods about 6 inches long, very straight, waxy-white and handsome. Popular for canning, as the beans are pure white. Extensively used both as a snap bean and as a dry shell bean; fine for baking. Very productive. Pkt., 10c; $1 / 2$ lb., 22c; lb., 40c; 2 lbs., 70c, postpaid.

PENCI POD BLACK WAX. The finest strain of Black Wax yet introduced and of the very best quality. Round pods 6 to 7 inches long and of uniform rich yellow color; entirely stringless, brittle, tender, meaty, exceedingly fine grained and without fibre. Medium-early, bears profusely and throughout a long season. Pkt., 10c; $1 / 2$ lb., 25c; lb., 45c; 2 lbs., 80c, postpaid.

PROLIFIC BLACK WAX. An old, medium-early sort which retains its popularity on account of its excellent quality. Very tender, crisp, mediumlong, yellow, round pods. Almost rust proof and very productive. Pkt., 10c; $1 / 2$ lb., 22c; lb., 40c; 2 lbs., 70c, postpaid.

WARDWELI'S KIDNEY WAX. One of the most desirable wax beans for the home garden, and a great favorite with market gardeners on account of great productiveness and the large size, handsome appearance and fine quality of the pods. Golden yellow, of rich, luscious flavor and exceptionally brittle and tender. A week or ten days later than the medium-early sorts. Pkt., 10c; 1/2 lb., 25c; lb., 45c; 2 lbs., 80c, postpaid.

DWARF GREEN-PODDED BEANS

One pound of seed for 75 feet of row

\section{Bountiful}

EARLIEST GREEN POD BEAN AND A CONTINUOUS BEARER

This superior variety is of thrifty growth, very hardy and practically rust and mildew proof. It bears continuously for several weeks, being the first to give pods fit to pick in the spring and the last to yield edible pods in the fall. Under favorable conditions of soil and season this variety has been known to bear one bushel of pods per 15 foot row, in the course of the season. The large green pods are thick, broad, flat, extra long, very uniform in shape, solid, meaty, and of high quality, tender, of delicious flavor ind absolutely stringless. Ready for picking in 38 to 42 days. Prt., 10c; 1/2 lb., 25c; lb., 45c; 2 lbs., 80c, postpaid.

BURPEE'S STRINGLESS GREEN POD. An extra early, roundpodded, prolific sort, bearing abundantly, long, bright green, stringless pods of excellent quality. Pkt., 10c; $1 / 2$ lb., 22c; lb., 40c; 2 lbs., 70c, postpaid.

GIANT STRINGLESS GREEN POD. The plants are of strong growth, making large, compact bushes, and are very productive. The pods are straight, quite long, nearly round, meaty, brittle and stringless. A few days later than Burpee's Stringless, and are borne continuously for weeks. Pkt., 10c; $1 / 2$ lb., 25c; lb., 45c; 2 lbs., 80c, postpaid.

SPECIAL PRICES for Market Gardeners and

SPE. 77 and 78 .

INOCULATE Your Bean seed for best results. Hasenriches the soil. Once tried on garden Beans. it will always be used. Price, Garden Size sufficient for $5 \mathrm{lbs}$, of seed, 25c, postpaid.

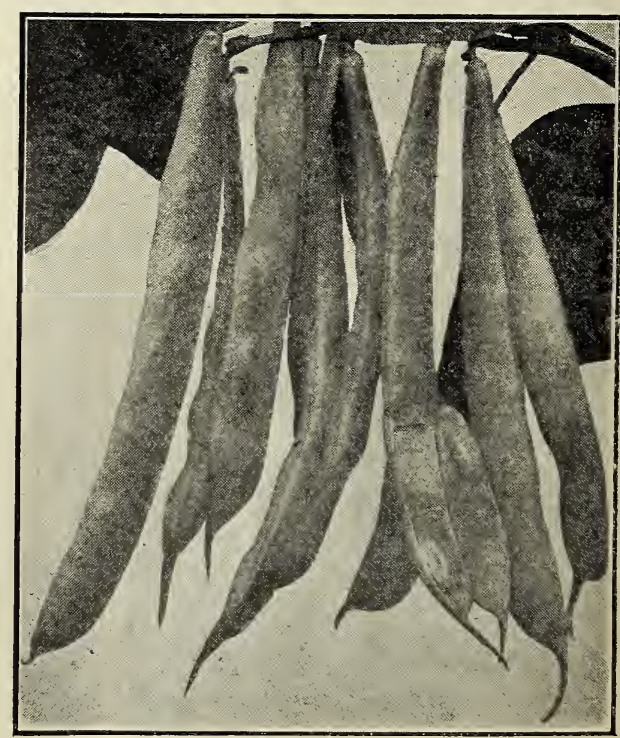

Bountiful 


\section{Full Measure}

Full Measure is decidedly the best round podded, stringless, dwarf green bean in existence, and on account of its superior quality, it is especially desirable for the home garden. It begins to bear with the second-early sorts, the heavy pods producing tliroughout a long season. Very productive; pods average 6 inches long, fleshy and absolutely stringless. Pkt., 10c; 1/2 lb., 25c: lb.. 45c; 2 lbs.. 80c. postpaid.

REFUGEE OR 1000 TO 1. The latest of the green podded beans, the most igorous in growth, and one of the most productive. For mild, rich flavor no dwarf bean can surpass it. Stringless when just fit to eat; afterwards quite stringy. A favorite for market and canning purposes. Pkt., 10c; 1/2 1b., $22 \mathrm{c} ; 1 \mathrm{~b} ., 40 \mathrm{c} ; 2$ lbs., 70c, postpaid.

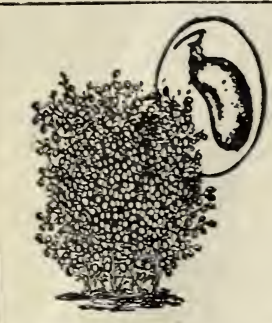

\section{The "Chestnut Bean"}

This wonderful Bean looks like a gigantic Pea. When boiled it has a flavor like boiled chestnuts, and is one of the most delicious beans grown. Grows in the form of a tall bush, and is completely covered with pods. For soup and turkey stuffing it can not be surpassed. It is a Spanish Bean, and is known as the "Garbanzo" Bean. Pht. 10c; 3 pkts., 25c; $1 / 2$ lb., 40c; lb., 75c, postpaid.

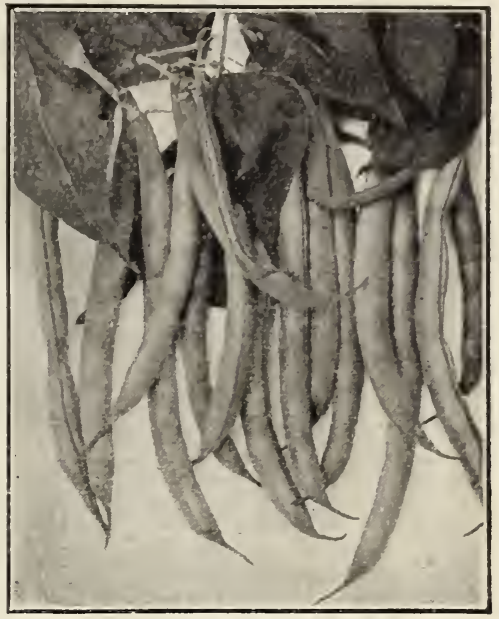

Foll Measure

\section{BURGESS' MICHIGAN GROWN FIELD BEANS}

\section{Sixty poundis will plant an acre.}

MICHIGAY MTPROVED PEA OR NAVY. No other farm cop has seen such a great advance in price as Beans. t is one of the greatest morev-making crops for those growers who have the foresight to plant selected pure seed, as they are receiving a good substantial premium over the ordinary mixed white bians that are still grown Y so many fermers. The Michigan Improved Pea or Navy is the greatest Bean for a farm crop that we have ever seen. Side by side with any bean known to us, our
improved strain will yield fully one-third to one-half more.
The pods are large and flled with medium-sized, pure white nearly round beans, which excel in cooling quallties. It is very early, having dry beans in 80 days from planting. It is an upright grower, holding the pods wel up from the ground. The pods grow in thick clusters and ripen in August, the leaves falling earlier than other varieties. No other bean approaches it in yield, quality, and readiness to find sale on the market. Pkt., 10c; $1 / 2 \mathrm{lb}$., $20 c ; 1 b . .35 c$; 2 lbs., 65c; 5 lbs., $\$ 1.30$, postpaid. For prices in quantities by express, see page $\mathbf{7 6}$.

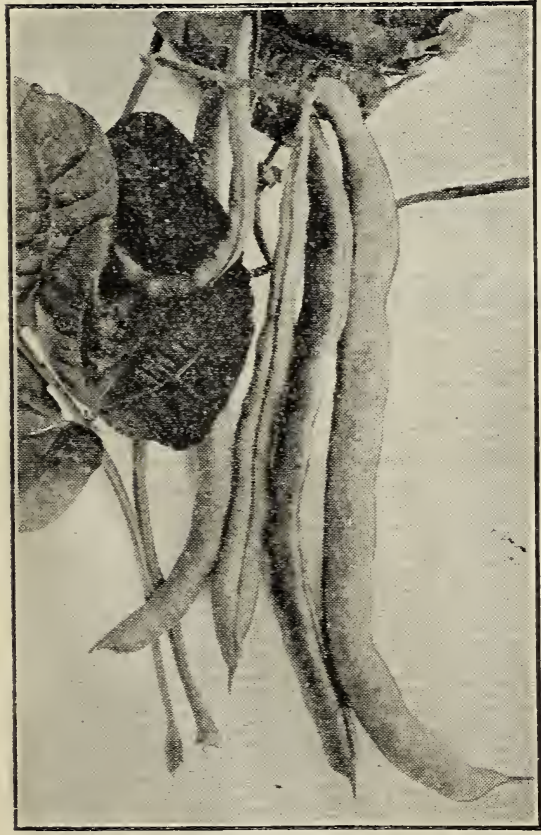

Burgess' Everbearing Kentucky Wonder

\section{POLE OR CLIMBING BEANS One pound of seed for 100 poles Burgess' Everbearing Bean}

Burgess' Everbearing or Everbearing Kentucky Wonder is without exception the finest flavored snap bean grown. The green pods, seven to ten inches long, are so fleshy they are often greater in thickness than width. They are solid, meaty, and very crisp. They commence bearing exceedingly early for a pole or climbing sort. and if pods are gathered as they mature the vines will continue to bear until killed by the fall frosts. This is one of the few poie beans that will bear a satisfactory crop without being poled. It will not produce as large a crop if grown without poles but will be more productive than any of the dwarf sorts. By planting a few hills in your corn. the corn stalks will act as a support for the vines, and you will get a good crop of both corn and beans. Pkt., SCARLET RUNNER. A fine ornamental vine. bearing large sprays of bright scarlet pea-like flowers and abundance of edible beans. Used both for shell and snap beans. Pkt., 10c; $1 / 2$ lb., 30c; lb., 50c, postpaid. Yard Long Bean This is an excellent variety, curiosity. The vines are rampant growers and produce an enormous crop of long, slender, round pods which are of excellent quality for snap beans. The round pods are from 2 to 4 feet in length. having the thickness of a lead pencil. Produce late in the summer, very productive, tender and of fine flavor. Pkt. $10 \mathrm{c} ; 3$ plits., 25c; 1/: lb., 50c; 1b., \$1.50, postpaid.

\section{Market Gardeners' Prices on Page 76}

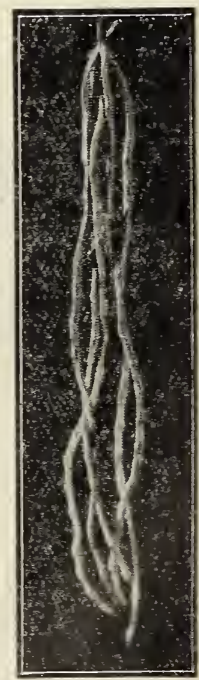

Yard Long

FRENCH ASPARAGUS BEAN This wonderful bean is the only rival of the famous Iard Long Bean. The loaded with pods of about 2 feet in length. It is delicious as a snap bean, as a green shelled bean, and as a soup bean when ripe. It is a dependable variety and, owing to its extraordinary quality, is sure to become very popular. Pkt., 10c; 3 phts., 25c; 1/4 1b, 50c, posipaid.

For Best Results with Beans, inoculate your seed. Hastens maturity, increases the yield and enriches the 25c: Half Bushel size (for Beans only), 65c; Bushel size (Beans only), \$1.00. Inoculation Bood for Peas only at Peas, same prices. 


\section{Bush Lima Beans}

One pound of seed for 100 feet of row

BURPEE'S IMPROVED BUSH. The largest of all Bush Limas, bearing pods almost equal in size to those of the large Pole Limas. Pods 5 to 6 inches long bv $11 / 4$ inches wide and the full size beans are of luscious flavor. Pkt., 10c; 1/2 lb., 25c; lb., 45c; 2 lbs., 80c, postpaid.

FORDHOOK. Nearly as large as Burpee's Improved and about a weels earlier. Extremely prolific, with large, thick, meaty Beans of delicious quality. Pkt., 10c; 1/2 lb., 30c; lb., 50c; 2 lbs., 90c, postpaid.

HENDERSON'S BUSF. The earliest Lima grown and continues to produce until killed by frost. Will produce an abundant crop under a wider range of weather and soil conditions than any other Lima. Beans are not large, but the quality is excellent. Our Michigan grown seed is a week earlier than Western seed or seed grown farther south. Pkt., 10c $1 / 2$ lb., 22c; lb., 40c; 2 lbs., ;0c, postpaid.

SPECIAL OFFER ${ }^{\text {one packet of each of the above three varieties }}$ postpaid.

\section{Pole or Climbing Lima Beans}

One pound of seed for 50 poles.

EARLY LEVIATHAN. Fully a week earlier than any other Pole Lima; a sure cropper and extremely productive, both early and throughout the season. Pods straight and long and well filled with large, thick beans of delicate pale green color and of a delicious buttery flavor. Pkt., 10c; 1/2 1b., 25c; lb., 45c, postpaid.

KING OF THE GARDEN. A vigorous grower, requiring but two vines to each pole. $B$ gins flowering early, at the bottom of the pole, producing a continuous bloom and fruitage throughout the season. Pods are large and beans are of excellent quality, well-formed and mammoth in size. Pkt., 10e; 1/2 1b., 22c; 1b., 40c, postpaid.

\section{Brussels Sprouts}

One ounce of seed for 200 feet of row.

A variety of the Cabbage family, possessing the peculiarity of bearing upon its stem or stalk from 50 to $100 \mathrm{small}$, compact round heads, each measuring from 1 to 2 inches in diameter. These heads are cut off when well formed and are usually marketed in quart berry boxes. The plants are very hardy, are not injured' but improved by hard frosts, and are left in the garden or field during the early winter until wanted. May be had in fine condition until about Christmas time in the North, and in the South may be had from November to March. These miniature Cabbages may be boiled like Cabbage or cooked in cream like Cauliflower. They are the most delicious and delicately flavored of the Cabbage family.

MIPROVED HALF DWARF. The best variety for all localities; very productive. Pkt., 10c; oz., 25c; 1/4 lb., 75c, postpaid.

\section{Borecole, or Kale}

One ounce of seed to 150 feet of row.

DWARF SCOTCH. The best variety. Hardier than Cabbage, and excellent for greens for winter and spring use. Pkt., 5c; oz., 12c; 1/4 lb., 35c; lb., \$1.00, postpaid.

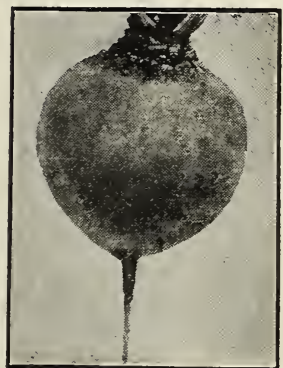

Detroit Dark Red Beet

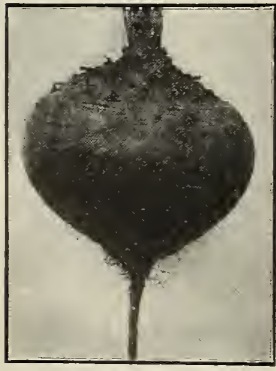

Crosby's Egyptian Beet

\section{BEETS-Table Varieties}

One ounce of seed to 50 feet of row.

CROSBY'S EGYPTIAY. (Selected Strain). The best extra early variety. The skin is very smooth and bright red; flesh vermilion, very sweet and tender. A money-maker ior market growers. Pkt., 8c; oz., 15c; 1/4 lb., 40c; lb., \$1.25, postpaid.

DETROIT DARK RED. The best main crop variety, and the roots can be used early in the season when only partially grown, being ready for use almost as quickly as the extra early sorts. Form globular or ovoid; smooth and regular in form, with small taproot and free from rootlets. Flesh is fine grained, tender and sweet. Retains its choice quality and freedom from woodiness until the beets attain their full size. A favorite for canning because of its rich extra deep dark red color. Pkt., 8c; oz., 15c; 1/4 lb., 40c; lb., \$1.25, postpaid.

EARLY BLOOD TCRNIP. An exceedingly popular, early, round, deep-red beet of excellent quality. Pkt., 5c; oz., 12c; 1/4 1b., 35c; lb., \$1.00, postpaid.

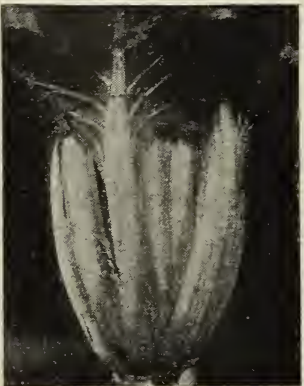

Spinach Beet

FARLY ECIIPSE, Fiarly, roots globular in shape, flesh finegrained, very sweet, crisp and tender; bright red, zoned with lighter shade. The tops are small, admitting close planting. Pkt., 5c; oz., 12c; 1/4 lb., 35c; 1b., \$1.00, postpaid.

LONG SMOOTH BLOOD. The leading variety for winter use. Good sized, long, tapering, smooth roots; dark red; sweet and tender, remaining so until spring. Pkt., 5c; oz., 10c; $1 / 41 \mathrm{lb} ., 30 \mathrm{c}$ lb., 90c, postpaid.

SPNACH BEET (INPROVED MAMMOTH SWISS CHARD) Grown extensively for its large, juicy, tender leaves and lea stalks. The leaves grow to a length of 2 to $2 \frac{1}{2}$ feet, and the stalks are nearly as thick and broad as Rhubarb and never get tough. By picking off the large outside leaves, as wanted, more leaves continue to grow and keep right on growing until killed by severe frost in the fall. The whole leaf can be used for greens, or the leaf stalks can be cooked
Pkt., 8c; oz., 15c; $1 / 4$ 1b., $40 \mathrm{c} ; 1 \mathrm{lb.} \$ \mathbf{1 . 2 5}$, postpaid. 


\section{Sugar Beets and Mangel Wurzels}

Mangels and Sugar Beets are very important crops, furnishing a tremendous yield per acre of a very healthful and nutritious food that is greatly relished by all kinds of livestock. Will keep cattle in perfect physical condition and increase the flow of mill. As a substitute for green feed for poultry, during the winter months, they are very valuable and always increase egg prođuction.

Yields of 25 to 35 tons per acre are common, and as high as 75 to 80 tons have been reported. The seed should be sown thinly in rows 2 to 3 feet apart, and when plants are about 3 inches high thin out to stand 8 to 10 inches apart in the row. Harvest before frost and store in pits outdoors or in a dry, frost-proof cellar.

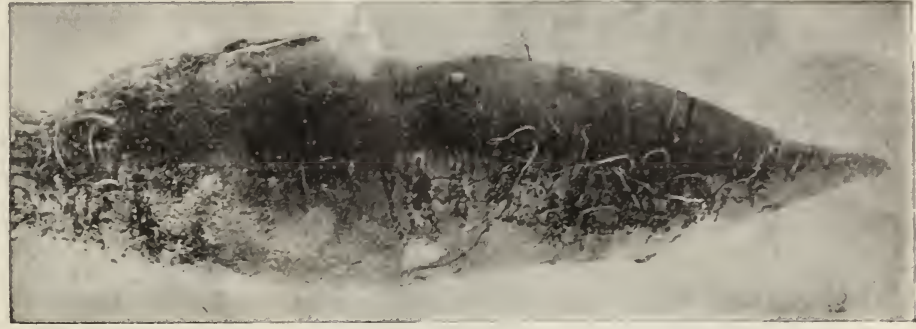

Mammoth Long Red Mangel Wurzel

One ounce of seed to 100 feet of row; 5 or 6 lbs. per acre.

GIANT HALF SIGAR. A fatorite with many dairymen. Flesh white, sugary and of high nutritive value. Yields a Plt, 5e; oz., 8c; 1/4 lb., 20c; 1b., 60c, postpaid.

KLEI WAXZLEBEX. Practically all the leading authorities on Sugar Beets have united in recommending this variety as possessing the highest sugar-producing qualities, as much as 18 tons of sugar having been made from 100 tons of roots. Also highly recommended for stock feeding. An enormous yielder. Pkt., 5c; oz., 8c; 1/4 lb., 20c; lb., $60 \mathrm{c}$, postpaid.
GOLDEN TANTARD. A rapidly maturing Mangel adapted to shallow lands, although doing well on every soil. An immense yielder. Rich, golden skin; flesh yellow, Easily harvested; excellent keeper. Pkt., 5̌c; oz., 8 e $1 / 1$ ib., 20c; lb., 60c, postpaid.

MAMroTH LoNG REN. The largest and the heaviest cropper of all Mangels. The rowts are frequently 2 feet or more in length. one-half to two-thirds above the surfac and easily harvested. Skin bright red; flesh white, veined pink. Keeping qualities not excelled. Pkt., jc; oz., 8c; $1 / 4$ 1b., 20c; lb., 60c, postpaid.

\section{CELERY ASPARAGUS (Sea Kale)}

One ounce will produce about 200 plants.

Celery Asparagus, or Sea Kale, is a wonderful vegetable which is practically unknown in this country but, owing to its extraordinary merit, is worthy of general cultivation. It is a perennial which dies down each fall and comes up again in the very early spring, ahead of Asparagus. It is cultivated somewhat like Asparagus, and it takes about the same length of time to get a bed well established. Its blanched stalks are cooked like asparagus and are ready for use earlier than Asparagus. These shoots can also be had during the winter by digging the roots and forcing them in the same way as Witloof Chicory, which you will find explained on page 13. The leaves are also used for greens. It is one of the most delicious of all regetables; combines the flavor of Asparagus with that of Celery; and coming so early in the season makes it especially desirab?e. Sea Kale comes usually from seed but can be grown from offsets or root cuttings. It can be grown anywhere and should be in every garden. Don't fail to get a bed started this season. Pkt., 10e; 3 pkts., 25c; oz., 65c, postpaid.
CHERVIL

EXTRA FINE CCRLED. A hardy what resembling, but more beautiful than Parsley, and by many considered superior to it in flavor. The young leaves are used in soups and salads and for garnishing meats and vegetables. One ounce will sow 100 feet of row. Pkt., 10c; oz., $25 \mathrm{c} ; 1 / 4 \mathrm{lb}$. isc, postpaid.

COLLARDS gEorgLA. The leading and best cabbage that usually succeeds in form of loose-headed sorts of cabbage cannot be grown to perfection. In the South they continue to grow all winter long and the tender tops are cooked like ordinary Cabbage, which they resemble greatly in flavor. One ounce will sow 100 feet of row Pkt., 5́c; oz., 10c; 1/1/1 lb., 25e; lb., 75c, postpaid.

\section{CARROTS}

One ounce for 100 feet of row; 4 pounds per acre.

CHANTENAY. An elegant bunching Carrot and early main crop sort for the market gardener. Of deep orangered color. In earliness it ranks intermediate between the Early Scarlet Horn and Danvers Half Long. Of the style of Danvers, hardly as large, but finer and more symmetrical Pht., 5c; oz., 15e; 1/4 lb., 40c; lb., \$1.25, postpaid.

CORELESS. A new rapid growing early variety of superior flavor; tender and without any woody heart or core.
Roots are half-long, blunt-pointed, and grow to a medium size; are very smooth, and of a deep orange-red color. Fighly recommended for market or home use when eithe roung or full grown. Pkt., 10c; oz., 20c; 1/4 lb., 55e; lb. \$1. $\%$, postpaid.

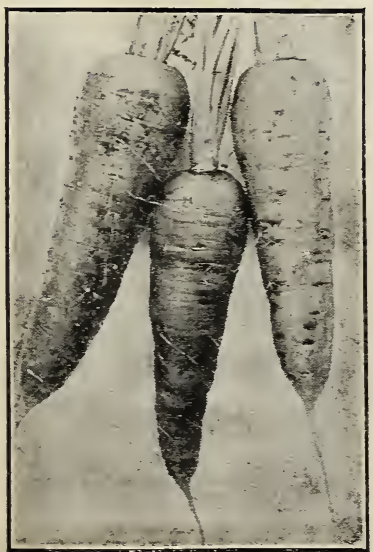

Danvers Half Long

DANTERS HATF LONG. A variety that is adapted to all soils and is enormousiy productive, often vielding more than the large field carrots and is much easier harvested on heavy ground. 5 to 6 inches in length; flesh very tender and sweet and a rich orange çior throughout; tine grained and free from woody fiber. Ready for table use in 70 days. Pkt., je; oz., $15 \mathrm{e} ; 1 / 4$ lb., $40 \mathrm{e} ; 1 \mathrm{~b} ., \$ 1.25$, postpaid.

EARLY SCARIET HORN. Te believe that our strain of this variety is the earliest Carrot grown. Tcos small, roois orly $21 / 2$ to 3 inches in length; too small for main crop variety, but very valuable on account of its extreme ear'iness. Ready for table in 50 to 55 days. Plst., 5e; oz., 15e; 1/4 lb., 40e; 1b., \$1.25, postpaid.

MIPROVED LONG ORAXGE. Tniform in shape and size, 8 to 10 inches long; smooth and of rich orange color. An excellent keeper. Fine quality for table use. Also planted extensively for stock feeding on account of its high yielding qualities and food value. Succeeds best in light soil. Ten days later than Danvers. Pkt., 5c; oz., 12c; 1/4 lb., $35 \mathrm{c} ;$ lb., \$1.00, postpaid.

NAXTES. A handsome variety, roots measuring 6 inches long and $11 / 2$ inches thick, almost perfectly criindrical, blunt-ended, smooth, and very small tap-root. Flesh fine grained and free from hard fiber or core. Bright orange-red color, sweet and mild. Of superb quality. Pkt., כ̌c; oz., 15c; $1 / 4 \mathrm{lb} ., 40 \mathrm{c} ; \mathrm{lb} ., \$ 1.25$, postpaid.

OXHEART. The best variety to grow on soils too hard and stiff for longer-rooted sorts. Root short and thick, nearly as thick as long but of good size and excellent quality. Season same as Danvers. Pkt., 5̃c; oz., 12c; 1/1 lb., 35c; lb., \$1.00, postpaid.

WHITE BELGLAX (Improved Mammoth). Probably the best of all field or stock carrots because of its large size, enormous productiveness and most excellent keeping qualities. Pkt., 5e; oz., 10e; 1/4 lb., 25e; lb., 75e, postpaid. 


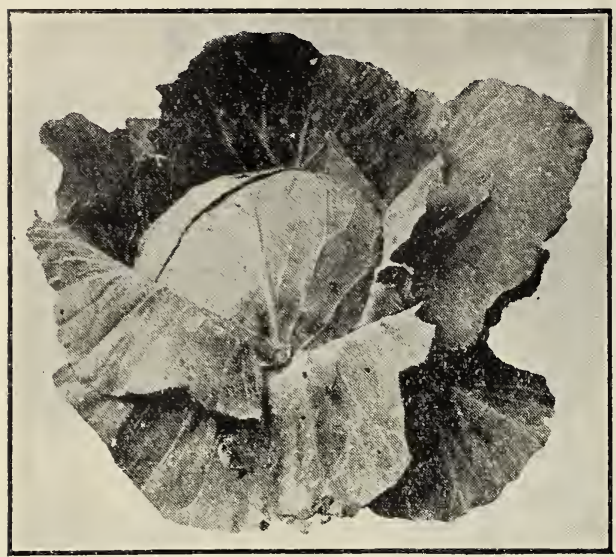

Copenhagen Market

\section{Cabbage}

In growing a profitable crop of Cabbage, much depends upon the seed planted. Our seed is all carefully grown from selected heads and under the supervision of expert cabbage seed growers. You can place an order for our seed with the assurance that you are getting the best that money can buy.

One ounce of seed for 2,000 plants; $1 / 21 \mathrm{lb}$. per acre.

\section{Lightning Express}

\section{THE EARLIEST CABBAGE IN CULTIVATION}

Our Lightning Express is ready for use in 65 to 70 days from sowing-ten days earlier than Jersey Wakefield. Good fair trials of varieties offered by other seed houses as "the earliest grown" have proved that they are from 4 to 10 days later than our Lightning Express. Lightning Express is positively the earliest Cabbage in cultivation. Heads pointed, of good size, a little smaller than Jersey Wakefield, always sure to head, solid and firm and always in demand on the market, bringing high prices on account of their extreme earliness. Very hardy, permitting earliest planting. There are but few outer leaves and the plants may therefore be set closely together. As many as 14,000 heads can be grown on one acre of ground, and will bring a larger profit per acre than later and heavier varieties. Pkt., 10c; oz., 40c; 1/4 1b., $\$ 1.25$; lb., \$4.00, postpaid.

EARLY JERGEY WAKEFIELD. Our Special Stock. The most popular early cabbage. About ten days later than our Lightning Express, but has larger heads and is more productive. Heads conical or pointed, solid and of the very best quality. Pkt., 8c; oz., 30c; 1/4 lb., 85c; 1b., \$2.75, postpaid.

CHARLESTON, OR LARGE WAKEFIELD. About a week later than early Jersey Wakefield. Heads are larger, tully as solid, and a little less pointed. An excellent variety to closely follow. Early Jersey. Pkt., 8c; oz., 30c; 1/4 lb., 85c; 1b., \$2.75, postpaid.

EARLY WINNIGSTADT. About the same season as Charleston Wakefield. Heads pointed, medium size and solid. A popular sort for the garden, as it remains in good condition for a long time. Pkt., 8c; oz., 25c; 1/1 1b., 75c; lb., \$2.50, postpaid.

\section{New Golden Acre}

\section{EARLIEST ROUNd head Cabbage}

Our special strain of this wonderful new Cabbage will mature hard, round heads, nine inches in diameter, of five pounds each, in 70 to 75 days from time of sowing seed. Uniform in size and growth; compact in habit, with few outer leaves, permitting close planting. The heads are firm and solid and fully equal to any of the late sorts, and will stand in the field for a month or more without bursting. The most profitable variety to raise for the early market. Pkt., 15c; 2 pkts., 25c; oz., 60c; $1 / 41$ lb., $\$ 1.80 ; 1 b$. $\$ 6.00$, postpaid.

\section{Copenhagen Market}

One of the most valuable varieties for the home garden and one of the most profitable for market gardeners. With the exception of Golden Acre, it is the earliest roundheaded Cabbage. In season it ranks with Early Jersey Wakefield, which it will outyield to to one in weight of crop on a given area. When ready for cutting, Copenhagen Market is the heaviest of the extra-early varieties and is as good, in its class, as the old favorite Danish Ballhead. The stem is short; the head is round and solid, averging 8 to 10 pounds each, and uniform in shape and size. A vigorous grower and an excellent keeper. The heads all mature at one time, and will stand longer without bursting than other early sorts. Many large growers consider Copenhagen Market as the best of all early cabbages. Pkt., 10c; oz., 40c; $1 / 41 \mathrm{~b} ., \$ 1.25 ; 1 \mathrm{~b} ., \$ 4.00$, postpaid.

GLORY OF ENTHUIZEN. Ten days later than Early Jersey Wakefield, but heads twice as heavy. Grows large, solid, round heads with few outer leaves, and such
compact growth as to permit close planting. When trimmed, heads weigh from 6 to 8 pounds and are similar in appearance to a small Danish Ballhead. Size ideal for marketing; quality the very best; excellent keeper. Pkt., 10c; oz., 35c; 1/4 lb., \$1.00; 1b., \$3.50, postpaid.

ALL-HEAD EARLY. The largest flat-headed early cabbage. Very popular early variety; also popular for later planting for winter use. Excellent quality; good keeper. Pkt., 8c; oz., 25c; 1/4 1b., \%5c; 1b., \$2.50, postpaid.

EARLY DWARF TLAT DCTCH. An excellent large second-early flat variety, producing solid heads that mature much earlier than Late Flat Dutch. Pkt., 8c; oz., 25c; $1 / 41$ b., "5e; 1 b., \$2.50, postpaid.

SUCCESSION. Intermediate between the Early Flat Dutch and the Late Flat Dutch. The heads are large and flattened and run uniform in size and shape; solid, and are of splendid quality. Its great productiveness, sure cropping and long keeping qualities make it one of the best for general use. Pkt., 8c; oz., 25c; $1 / 4$ lb., 75c; lb., \$2.50, postpaid.

AwT SEASOxs. Large heads, round, flattened at top; extremely hard and solid; a sure header. A leading variety for kraut. Good for autumn or winter use as well as for early summer. Pkt., 8c; oz., 25c; 1/4 lb., 75c; 1b., \$2.50, postpaid.

PREMIUM LATE FLAT DCTCH. A most popular large flat, late variety; quality unsurpassed. Plkt., 8c; oz., 25c; 1/4 lb., '5c; lb., \$2.50, postpaid. 


\section{Danish Ballhead}

(TALL STEM)

The most nonular cabbage for winter; very fine grain, tender and crisp. The heacis : re medium sized, round, and so hard and solic that they will weigh one-fourth more than other varieties of equa size, and $w^{\prime}$ ll stand shipping better than other sorts. It is not necessary to dispose of the crop in the fall if market prices are not satisfactory. The crop call be siored just as safely as potatoes. and they will be just as solid in the spring as when put away in the fa!l. Esvecia!ly recommended for the Northern States. Pkt.. $10 \mathrm{c}$; oz., 35c; 1; lb., $\$ 1.00$; lb., $\$ 3.50$, post paid.

\section{Danish Roundhead}

\section{(SHORT-STEM B.LLLHEAD)}

A short stemmed type of the well known and much prized Danish Ballhead Cabbage. Danish Roundhead has all the desirable quali. ties of the Danish Ballhead, heads of the same size, as round as balls and as solid as bullets. Fully two weeks earlier and will keep and ship as well as Danish Ballhead. Pkt., 10c; oz., 35c; $1 / 4$ ib., \$1.00; lb., \$3.50, postpaid.

SIREHFAD. One of the best late cabbages, of the Flat Dutch type, weighing ordinarily from 10 to $15 \mathrm{lbs}$. each. Of very fine oualit:. so'id. and of fne texture. Drought resisting. about 10 days earlier than Danish Ballhead and certain to head. Grown extensive'y for winter use and one of the best keepers. Te recomi mend Sureh ad for the home garden. Pkt., 8c; oz., 25c; 1/4 1 b. 75̃c; lb.. \$2.50, postpaid.

JurBo. The largest cabbage grown; 20 to 30 pounds each. Heads flat. rounded at top; very solid; sure to head; excellent keeper. The qualitr, for slicing. for kraut and for genera tab.e use is unsurpassed. Plit., 10c; oz., 40c; 1/4 1b., \$1.25; lb., \$4.00, postpaid.

MAMIOTH ROCK RED. The largest and the rery best red rariety. Pkt., 10c; oz., 35c; $1 / 4$ lb., $\$ 1.00 ;$ lb., $\$ 3.50$, postpaid.

AMErICAY DrCMAEAD SATOY. The Savoss excel all other cabbages in flaror, and our tmproved strain of American Drumhead is the best of the Saroys. Crimped leaves; more tender. milaer, and sweeter than the smooth-leaved varieties. No garden complete without this wonderful cabbage. Plit., 8c; oz., $30 \mathrm{c}$; 1/: Ib., 90c; lb., \$3.00, postpaid.

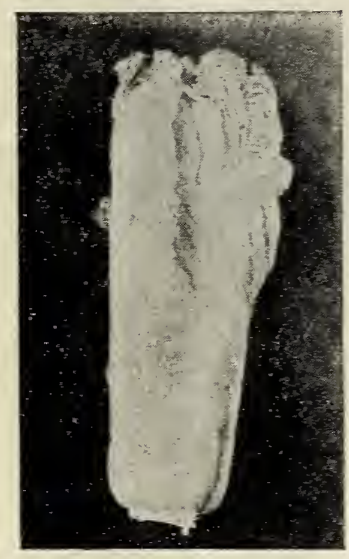

Chinese Celery Cabbage

\section{Chinese Celery Cabbage}

A most delicious regetable which combines the rich celer flavor with that of the cabbage. Can be cooked or eaten raw like celery. Makes as good salad as the finest head lettuce. The mid-ribs can be cooked like asparagus, and for cold slaw no cabbage compares with it. One of the most delicious regetables yet introduced, and bound to become one of the most popular. Plit., 10c; oz., 30c: 1. :b.. 90c; ib.. S3.c0. postpaici.

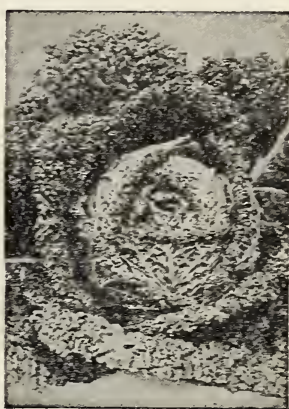

American Drumlieid Saroy

\section{Poultry Cabbage}

Poultry Cabbage is a wonderful green feed for poultry and has been known to yield 3 tons in a space $40 \times 60$ feet. You can't beat this for low priced green feed. One-half pound of seed will grow enough greens to feed about 1,000 hens for 4 months; 3 pounds to an acre for 6,000 hens for 4 months.

Poultry Cabbage is a rapid grower. In the Northern States the seed can be sown anytime from early spring until the middle of July. In some parts of the South the seed may be sown throughout the entire year, or from July to September for main crop. Sol in rows half an inch deep and 24 inches apart, allowing aboul ." inches between the seed. Cultisate and keep free from weeds. Commence feeding when plants are about 4 inches high. pulling out and feeding alternate plants. Continue thinning until plants are about one foot apart. These should make hends of 5 to 7 ponds in 60 days and may be fed immediately or allowed to stay in the ground until cold weather. These heals may be fed whole as they are very tender and 100 per cent
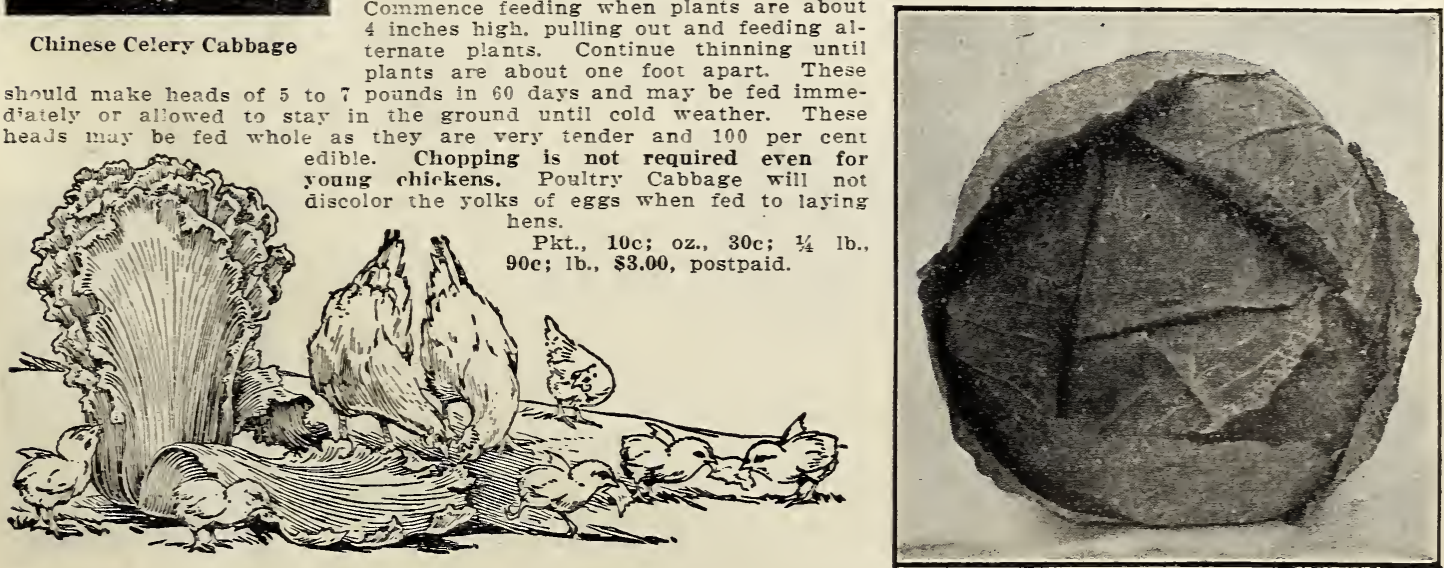


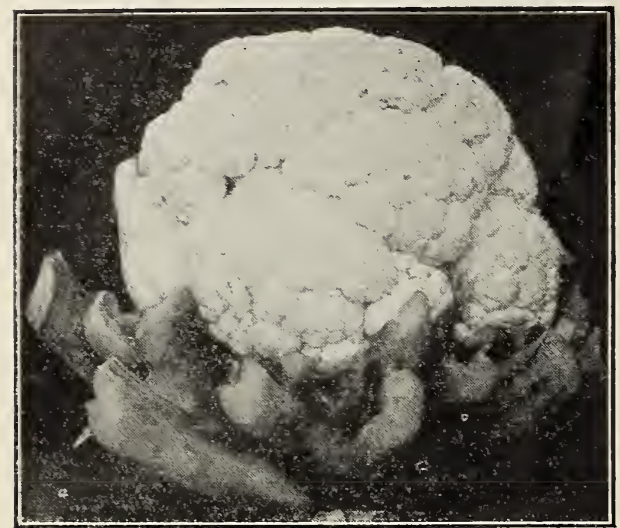

War?y sionitall

\section{Cauliflower}

One ounce of seed will produce 2,000 plants

EARLY SNOWBALL. Our select strain of Early Snowball is far superior to the seed orainarily sold of this variety and is the earliest Cauliflower grown. A very reliable heading variety with rich, snow-white, close. comnact head of the very bost quality. Pkt., 20c; $1 / 4$ oz., 70c; $1 / 2$ oz., \$1.25; oz., \$2.25; $1 / 4$ lb., \$7.50, postpaid.

EARIY DWARF ERFTRT. An excellent early variety. A little later than Early Snowball. but larger. Pkt., 15e; $1 / 4$ oz., 69e; $1 / 2$ oz., $\$ 1.00$; oz., $\$ 1.80$; $1 / 4$ lb., $\$ 6.00$, postpaid.

DRX WEATHER. A large second-early rariety, producing imcompact heads of the very best quality. Will grow an head in hot, dry districts where it is difficult to grow other varieties. Extra select seed. Pkt., 20c; 1/4 0z., 70c; 1/2 oz., \$1.25; oz., $\$ 2.25 ; 1_{14}$ lb., \$7.50, postpaid.

VEITCH'S ATTEMT GIANT. A very large, late variety producing quite compact while heads. Like all late varieties, it is not nearly so reliable as the early sorts excent in cool sections. Pkt., 10c; 1/2 oz., 35̄c; oz., 65̃c; 1/t lb., \$2.00. postpaid.

\section{CELERY}

One ounce of seed will produce about j,000 piants.

DWARF GOLDEX HEART. A leading main crop variety; dwarf, stocliy sort, with a full vellow heart. Ficellent quality; good keeper. Pkt., 10c: oz., 30c; 1/4 Ib., 90c; lb., \$3.00, postpaid.

GIAT PASCAL. Best of all for late fall and winter use, but too brittle to stand shipping any distance. A tall sort with large. thick and solid grern stalks, which blanch to golden yellow: crisp, of fine nutty flavor, and an excellent keeper. Pkt., 10c; oz., 30c: $1 / 4$ lb., 90c: lb., $\$ 3.00$, postpaid.

GOLDEX PLCUE. A new semi-dwarf early variety, producing thick and heavy stalks with a well-blanched solid heart; crisp and of the highest table quality. More vigorous than Golden SelfBlanching and quite resistant to blight and rot. Celery grow $\mathrm{r}$ who have tried it $r$ port it superior to any of the other early easy blanching types. Pkt., 15e; $1 / 2$ oz., 60e; oz., \$1.00; $1 / 1 \mathrm{lb.} \$ 3.50$ 13., \$12.00, postpaid.

GOLDEN SELF-BLANCHING. The most popular early variety. Plants of medium size, compact and stocky. As they mature the inner stems and leaves turn beautiful golden yellow so that blanching is effected at a minimum expenditure of time and labor. Handsome color, crispness, tenderness. freedom from stringiness, and fine nutty flavor have established it as a superior early sort. Plit., 10c oz., 60c; $1 / 4$ lb., $\$ 1.80$; 1b., $\$ 6.00$, postpaid.

WHITE PCTIE. The earliest celery in cultivation Stalks pure white, crisp and delicious. Pkt., 10c; oz., 30c; 1/4 lb., 90c; lb., \$3.00, postpaid.

WINTER QUECN. The finest dwarf winter celery, and the best keeper of all. Quite similar to Golden Self-Blanching in height and habit, but with leaves and stalks resembling Giant Pascal in color. Ready for market earlier than Pascal. Pkt., 10c; oz., 30c.

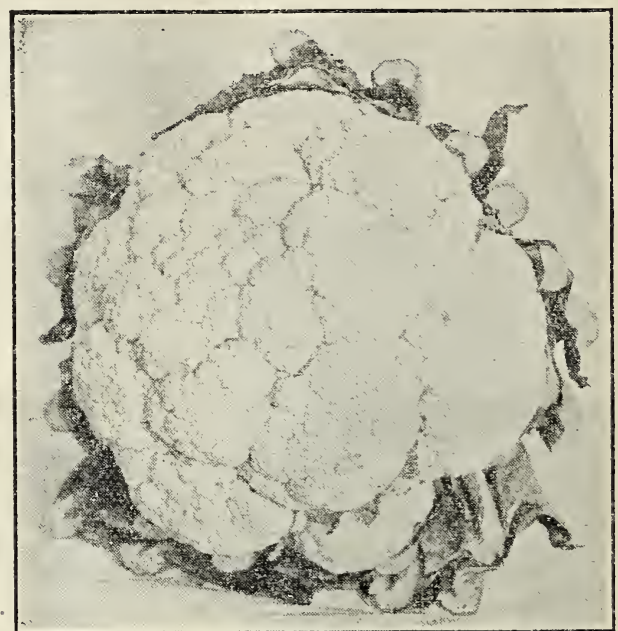

il:y Weather color. Ready for market earlier
$1 / 4$ lb., Doc; ib. 33 . ro. postpaid.

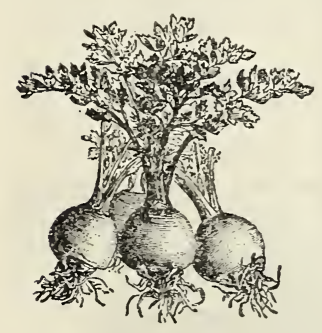

Celeri::

\section{CELERIAC (Turnip Rooted Celery)}

The edible portion is the large, swollen root, which is highly valued for salads, for boiling and for favoring soups, stews and other dishes. Celeriac boiled until quite tender and served cold with a French dressing is one of the most wholesome and delicious salads imaginable. Seed should be sown and given the same treatment as celery, except that no blanching is necessary. Roots are fit to use when about 2 inches in diameter. Will keep all winter like beets and carrots if packed in moist earth or sand.

GIANT PR.AFTE. The best variety of Celeriac. or Turnin Ronted Colery, protucing large roots of nearly globular shape. Pkt., 10c; oz., 30c; 1//4 1b., 90c; ib., \$3.00, postpaid.

\section{CHIVES or Schnittlaugh}

A hardy perennial onion-like plant. Highly esteemed for use as a salad, and for their small leaves which are produced very early in the spring and are used for giving a mild onion flavor to various dishes. Frequent cuttings may be made throughout the season, a new growth of leaves appearing soon after each cutting. Plit., 10c; 3 plsts., 2Je; oz,, 6óc, postpaidi.

\section{CORN SALAD OR FETTICUS}

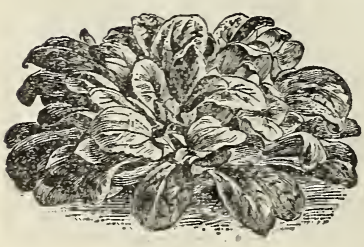

One ounce will plant 40 feet of row.

This is a hardy winter salad. th. leaves being served like lettuce during the cool fall and early winter months. It is used also for garnishing meat dishes in the same manner as parsley, and can be cooked like spinach. The seed should be sown thinly in drills during August or September, to supply fresh leaves during the cool fall and winter months. It is quite hardy but, in the Northern States. after cool weather sets in, it should be protected by a thin mulch of straw or leaves. Plit., 8c; oz., 15c; 1/4 lb., 40c; lb., \$1.25, postpaid.

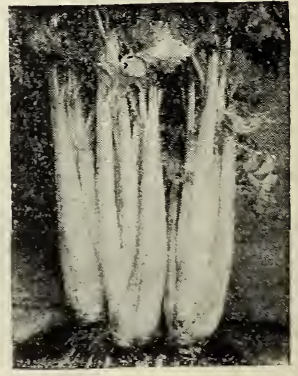

Golden Self-Blanching 


\section{Burgess' Michigan Grown Sweet Corn}

The take pride in our select strains of Michigan Grown sweet Corn, which is from $f v e$ This means a great deal to the gat tirst on the market, for it is then that the best prices are obtained. Michigan Swe short last season. For that reason. Michigan Sweet Corn cannot he sold in competit While our prices are higher than those charged by secismen who handle Western will be a most profitable investment. No matter where you ire. Nour our seed will critical market garden trade.
One pound for 150 hills: 12 to 16 lbs. per acre.

\section{Golden Sunshine}

THE E.ARLIEST TELLOW SWEET CORT

The earliest yellow Sweet ciolin Bantan. Mure dwarf in habit than Bantam. 1. inches long, containing 12 rows of broad, vellow grains. Especially desirable for its extrern arliness. and the equal of Bantam for sweetness and richness of flator. should be planted very home garden. Our Michigan grown seed assurs the market gardener of an exiremely ariy crop to be sold at high prices. Plit., 10c; $1 / 2$ lb., 2jc; lb., 45e, postpaid.

EARIY sisli TCHEW.I. The earliest white Sweet Corn, maturing with Golden Sunshine planted early. withstanding cold. Wet weather to a wonderful degree. Ears of gooc size for so early a variety: kernels pure white, sweet and tender. It is also rery productive ior an ariety fir home us and as a market sort it is a money maker. Pkt., 10c: $40 c$, posipaiel.

F.API.Y M.AYFIOMER. One of the whitest and sweetest of the early varieties. Much like Mammoth White (ory. but is sweeter and earlier. being ready for the table Varly saskatchewan. Ears

Plit., 10c; 12 ib., 20c; lb., 3jo, postpaid.

IMPPOVED GOLDEY BANT.MI. The most popular early sweet Corn; sweet, rich and delicious. In season it closely follows Early Mayflower. Ears 5 to $i$ inches in length and comBantam is

3je, postpaid.

PE ICE:S GOLDEY GIANT. As good to eat as Golden Bantam: only 4 or 5 days with ears 50 to 75 per ctnt larger. The cob contains 16 to 18 rows. Which completely entire surtace. On accuunt of the size of the ears it is a more profitable variety tha
Bantam for the market gardener to grow. Anoth $r$ notable feature is its heart husk, protects it from ravages of birds and worms. Pkt., 10e; 12 lb., 2ue; lb., 3jc, postpaid. YLATIOTH WHITE CORF.

Excellent quality. Plat., 10c; $1 / 2$ ib., 20c; lb., 3äc, postpaid.

GOLDEY EVERGPEEY. The best main crop rariety. the result of a cross between Sto E.r.

varicties and better than either.

as large as Stuwel's Evergreen and is of true Evergrcen habit remaining

in gool contirg

home garder ant fancy market trade

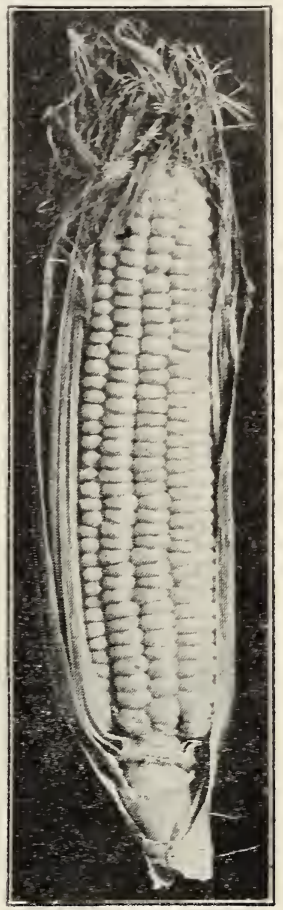

Golien Sunshine

STOFELL:S ETERGREEX. The standard main crop variety in all sections. Mrichigan gromn Stowells Erergreen is acomiz everwher as tha best tyoe of its classand. remains a long time in cooking condition. Pkt., 10c; 1/2 ib., 20c; 10., 3j̃e, postpaid.

corxTrX GENTLEIEx. The finest and streetest of all white rarieties. It can be ilentifed easil br the irregular irrangement oi the kernels on the cob. Excellent sort to grow where worms bother the ears, for irstead of working a row into the center of the producing less than three ears to the sta its own, and no garden is complete without it. A week later than Stowell's Evergreen. Pht., 10c; 1, lb., 20c; lib., 3se, postpaid.

\section{Pop Corn}

Four pounds of seed to the acre.

ACSTRALIAY HCLCESS. A.? ko knomn in some sectons as Japanese Rice, Tom Thumb. or Bumble Bee. A leary yielder of attractive little short ears, nearly as thick as long. Its croming merit is its popping aualits fine flaror and absence of hull or shell. Pht., 10c; 1/2 1b., 20c; Ib., 35c, postpaid.

BLACK BEACTT. Ripens earlier than any other rariety, jet the ears are large in size and the yield is as heary as that of any of the later sorts. Pops large and is the finest flaror d variety of Pop Corn. Although the Kernels are black, ther show up nice and $\pi$ hite $\pi$ hen popped. Pkt., 10c; 1; lb., 20c; Ib., 35c, postpaid.

QCEEX's GOLDEX. Stalks grow six feet high and the ears, which are produced in abundance. are larger than

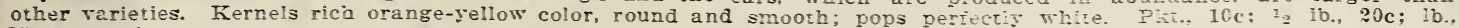
$35 \mathbf{c}$, postpaid.

WHITE RICE. The old standard and leading market rariety. The improved strain we offer is trery prolific, many stalks bearing four large, well developed ears. Pht., 10c; 1́2 ib., 20c; ib., 3je, postpaid.

SPECIAL OFFER One packet each of Australian Hulless, Black Beauts, Queen's Golden and White RiceSPECIAL OFFER all 4 pkts. for $25 \mathrm{c} ; 1 / 2 \mathrm{lb}$. of each, i0c, postpaid. 


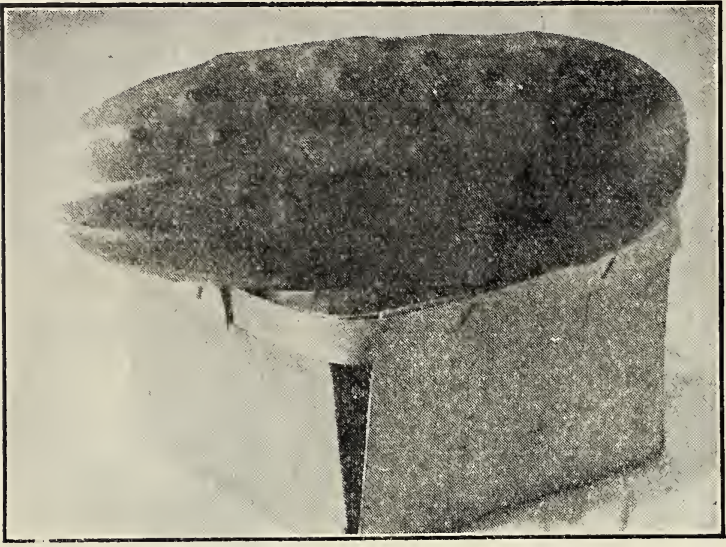

Burgess' Earlibest

\section{Cucumber}

One ounce of seed for 60 hills; $3 \mathrm{lbs}$. to the acre.

We take pride in our superior stock of Pedigreed $\mathrm{Cu}$ cumbers. Better seed cannot be produced anywhere. Market growers and private gardeners will make no mistake by planting our pedigreed seed. Bred for quality, earliness, hardiness, trueness to type and for increase in production. More than that, our seed will cost you no more than just ordinary Cucumber seed.

\section{Burgess' Earlibest}

THE EAPLIEST OF ALI SL"CING (UCUMBERS AN:) HOLUS ITS DEE? COLOR HETTER THAN

\section{ANY OTHER SORT}

Burgess' Earlibest is not on!y the finst slicer ready for the market, but the quality is equal or better than that of most of the laier sorts and it is a great yielder. It is the most profitable Cucumber for the early market. It is an extra early White Spine, handsome in shape and color, and holds its deep green color better than any other sort. Fruits grow very even in size, usually about seven inches in length, and regular in form. Color dark olive green with lighter lines running from blossom en 1; smooth, tender and crisp. It is very hardy, robust and free from disease. Ready for market in 55 to 58 days, The Agricultural Experiment Station of the State of Maine reports Burg ss' Earibest to be of fine quality and the earliest cucumber to be ready for picking. Pkt., 10c; oz., 15c; $1 / 4$ lb., 45e; lb., \$1.50, postpaid.

\section{Early Fortune}

Only two or three days later than Burgess' Farlibast, and fruits measure about two inches longer. Proclaimed by many growers as the finest type of White spine Cucumber. The color of the slin is rich darle green. the texture of

is very small. The plants grow vigorously and the fruits are set very freely all along the vines. One of its best features is its resistance to disease. In great demand by both home gardeners and market growers. Plit., 8c; oz. 15c; $1 / 4$ lb. 45̃c; lb. $\$ 1.50$, postpaid.

\section{MARKET GROWERS AND OTHERS USING SEED IN QUANTITY See Pages 76, 77 and 78}

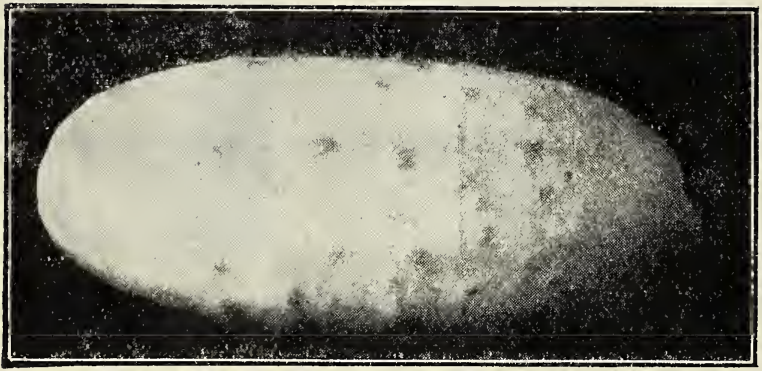

White Wonder

\section{White Wonder}

Color of White Wonder is beautiful pure white Remarkably uniform in shape and size, averaging 8 inches long by $2 \frac{1}{2}$ inches thick. Begins to bear early in the season and continues until fall. Flavor is pleasing and flesh firm and crisp. Fine sliced or in salads. Its smooth, clear surfare malies the White Wonder an ideal pickle. Aside from the excellent quality of the fruits, White Wonder bears a great quantity of them. A packet of seed will furnish you cucumbers in abundance. Pkt., 10 ; oz., 20c; $1 / 1 / 1$ lb., 60c; lb., $\$ 2.00$, postpaid.

\section{Davis' Perfect (Perfected Strain)}

With the exception of the New English Hybrid White Spine, our strain of Davis' Perfect is the most beautiful cucumber grown. By using our Perfected Strain a crop can be produced outdoors which cannot be distinguished from greenhouse stock. Fruits 8 to 10 inches long; rich, dark green. It has very few seeds, and the few that are in it when in slicing condition are so very small and tender they are unnoticeable. It loads its vines so heavily that it seems impossible for them to mature the fruit. Under glass it is the most productive variety, and for outdoor growing they yield even better than in the greenhouse. For quality it is unsurpassed. Ready for the market in. 60 to 65 days. Pkt., 8c; oz., 15c; $1 / 4$ lb., 45c; lb., \$1.50, postpaid.

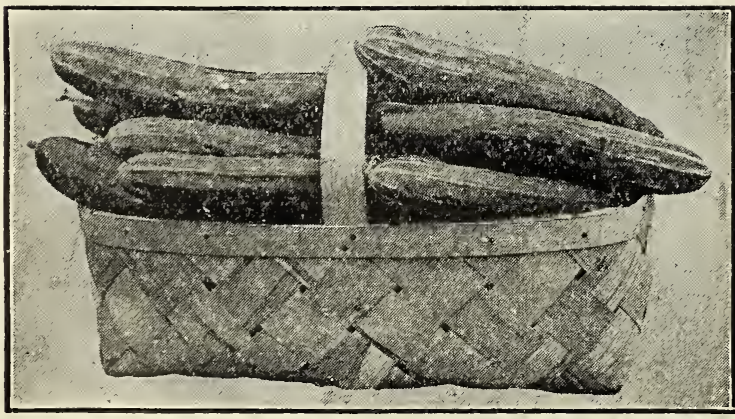

Davis' Perfect (Perfected Strain)

\section{China Long}

This is a remarkable new long green cucumber from China with fruits from 20 inches to 2 feet in length, and only 2 to 3 inches in diameter. The skin is deep green and nearly smooth, the spines being few and small. There is nothing equal to China Long for crispness except possibly some of the hothouse varieties; flesh solid and of the very best quality for siicing. The nearest seedless of any variety we have ever tried. Nearly as early as the shorter varieties; vines strong, vigorous, healthy and productive. A most desirable variety for the home garden, and is sure to be a popular market sort as soon as it becomes better known. Pkt., 10c: 3 pkts., 25c; oz., 50c; $1 / 4$ lb., \$1.50; lb., $\$ 5.00$, postpaid.

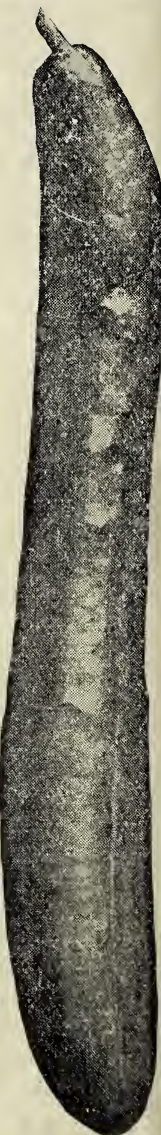

China Long 


\section{English Hybrid White Spine Cucumber} The Aristocrat of the Cucumber Family

EXgLISH IXBIIn WIITE SPINE is the result of a cruss beiween Ei:glish Tclegrapls and Evergreen White spine, and combines the viliabie clisracteristics of bot!1. It inherits the fine apsearance and shape of the English sort and the hardin ss and yic ling qualities of the White Spine. Besides its lingth, which is longer than the White spine varieti.s, it is much darler in color. The seed carity is rery smn., a factor distinct.y in its favor lish Hybrid White Spire is the ilea! varicty to plant for general crop and will prove to be a real money maker for the grower who caters to the better class of trade, bringing a better price than the shorter and less attractive sorts. Don't fail to put part of your crop in to English Hybrid White Spine. Pht., 10c; oz., 20c; 1/ 1b., 60c; ib., \$2.00, posıpisicl.

IUPROTFn LONG GPFEx. 12 to 16 inches in length: excellent quality. Foling fruits us d for pickling, being a standard sort for that purpose; larger ones excellen for slicing. The most popular variety for making sweet pickles frem the rine fruits. Pkt., \&c; oz., 15c; 1/4 lb. $45 \mathrm{c} ; 1 \mathrm{~b} ., \$ 1.50$, postpaid.

EVERBEARING. Tot on'y extreme'y prolific, but will continue in baring throtghout the season. Fruits dark green: arerage from 4 to 5 inches in length. Excellent 1b., \$1.25, postpaid.

WESTERFIELD' C CHECAGO PICKLNG. The standard pickling variety which has been us:d for rears by nearly all the leading pickle houses. Tery prolific. Pkt., 8c; oz., 15c; $1 / 4$ lb., 40c; lb., $\$ 1.20$, postpaid.

HFINZ SPECTIL. An improved trpe of pickling cucumber which is prizen aivore all other varieties for fancy pickles. Short $r$ than Westerfield's Chicago Pickling, and more uniform in size. shape and color. Fruits straight, smooth. symmetrical, solid, crisp. and of rich green color. The nearest blight-pronf of any variety. Pkt., 10c; oz., 20c; í/4 lb., Juc; lb., \$1.i5, postpaid.

TEST NDIA GHERK!Y. Small, oval-shaped, prickly fruit: used exclusive'y for pickling: very prolific. Pkt., $10 \mathrm{c} ;$ oz., 20c; $1 / 1 \mathrm{~b} ., 60 \mathrm{c} ; 1 \mathrm{~b} ., \$ 2.00$, postpaid.

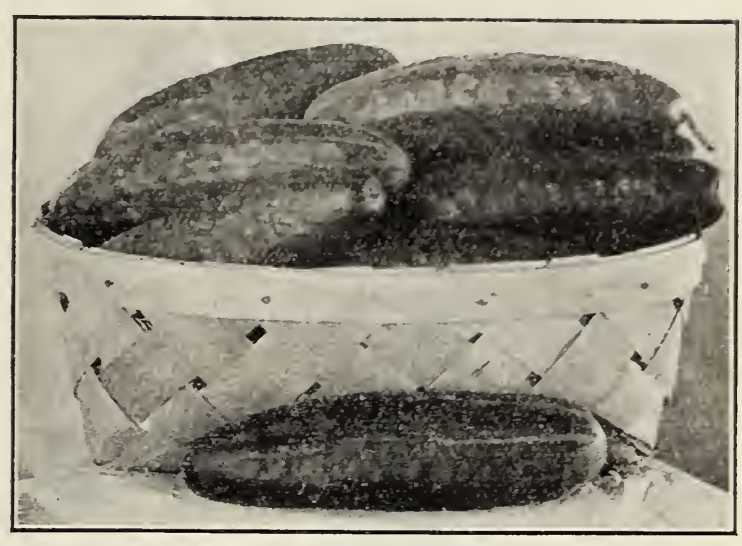

English Hybrid White spine

LEMON. A real Cucumber, similar in size, shape sn color to a lemon. It has a fivor that is sweeter an esteemed for pickling, either gre $\mathrm{n}$ or ripe, and for slicin just as the fruits are turning yellow. Will yield four time as many Cucumbers $2 \mathrm{~s}$ any other

JAPAXESE CLNIBRG. A good variety to plant to sav garden space. The vigorous and $\mathrm{h}$-althy vines throw ou strong tendrils, enabling them to climb trellis, wire nettin or any other suitable support. Owing to the foliage being up off the ground. it resists blight better than other kinds. Fruits long and thich, crisp, tender and of good quality. I kept picked, the vines nill bear freely all

\section{MARKET GARDENERS AND TRUCKERS Don't order until you have read what we} buy secd in quantities you can sire noney by ordering at our Thoesale Prices.

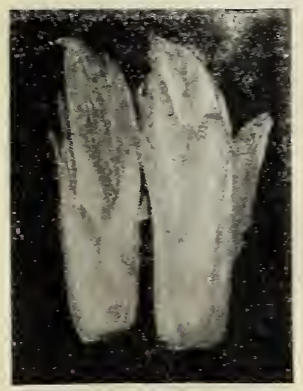

Wit'oof Chicory

\section{Witloof Chicory (Winter Salad or French Endive)}

\section{One ounce to 200 feet of row.}

Titlocf is a delicious Wintor regetable. It makes one of the finest of all salads. is rerr fine served with French dressing and eaten like lettuce, and is also excellent boiled. Plant seed in May or Jung in open ground and in the fall dig roots. cutting off the leares and store in soil in a cool place until wanted for forcing. About a month before wanted the roots should be planted in boxes of earth, in a cool, dark place in the cellar. If not grown in a dark place it shouid be banked up like celery, as it is the blanched stalks that are used. Coming, as it does. in the midale of the winter, it is bound to become popular as it becomes better known Plit.. 10c; oz., 25c; 1/4 1b., 75c; lb., 32.50, postpaid.

\section{Large Rooted or Coffee Chicory}

\section{One ounce to 2 co feet of row.}

The best coffee substitute ever discovered. The large roots, when roasted and ground, make a delicious, nourishing drink to take the place of injurious coffee. It is a pure food drink that gives health and strength to young and old. Grow your own coffee. and rour health and pocketbook will both be b-nefited. Plit.. 10c: cz.. 15e: 1, 1b.. 4.5c: lb.. s1.50. jostpaid.

\section{CRESS}

EXTRA CTRTED OP PEPPER GRASS. A salad plant that should be grown in ever: garden. Grows rery quickly and seed can be sown as early in the soring as the ground can be workcd. For succession make repeated sowings every two $\pi$ ceks from early

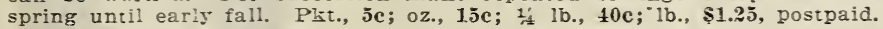

TRLE WATER CRESS. A hardy piant which will thrire well only when the roots are submerged in water. Can be easily grown in springs or along the edges of shallow running streams. One of the most delicious of all small salad plants. Pkt., 10c; 3 pkts., 25̃c; oz., 50c; 1: lb., \$1.50, postpaid.

UPLAND. Same flavor as Water Cress. Grows on high, äry land. As easily grown as spinach or lettuce. Hardy perennial that can be grown for several years without replanting. Pkt., 10c; oz., $30 \mathrm{c}$; 1/.t lb., $90 \mathrm{c}$; lb., $\$ 3.00$, postpaid.

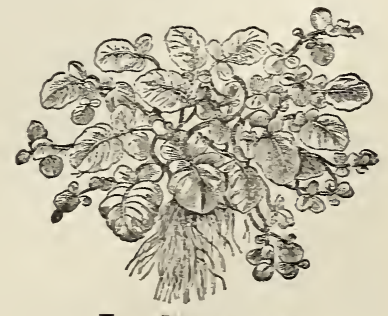

True Water Cress 


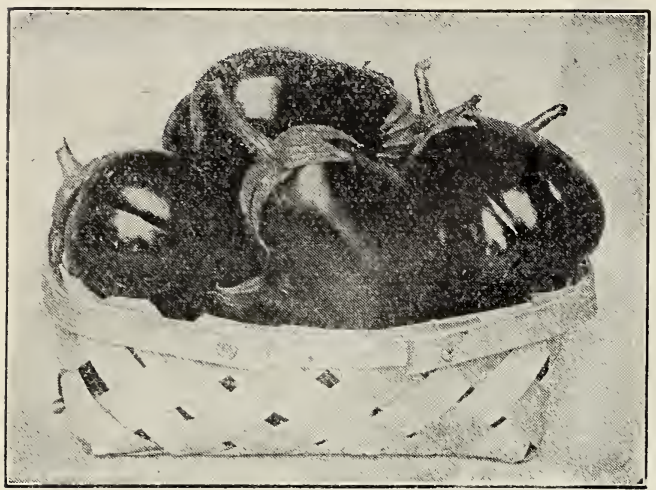

Black Beauty Fgg Plant

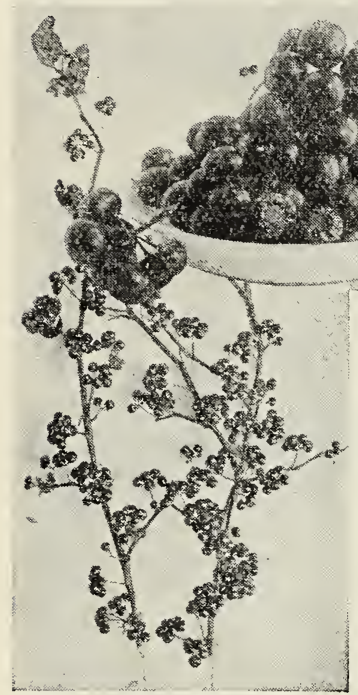

Garden Huckleberr,

\section{EGG PLANT}

One cunce of seed for 1,000 plants.

BLACK BEALTY. The best and the earliest of all large fruited Egg Ptanis. It is valuable alike to the private planter and to the extensive grower ior market. Biack B auty produces fruits fully as large as, and ready for use 10 days to 2 weeks earier than the New York Improved Spintless. The large fruits are thick, of most attractive form. The skin is a rich, lustrous purplish black. The intensely brilliant coloring is uniform over the whole fruit and does not fade or change to a lighter color at the blossom end. The calyx is bright green, contrasting finely with the dark satin skin of the fruit. and is entirely free from spines or thorns. The fruits set most freely and develop very quickly, so that the entire cron can be gathered before there is any danger of frost. Pkt.. 10c: 3 pkts., 25c: oz, 50c: $1 / 4 \mathrm{lb}$., $\$ 1.50$; lb., \$5.00, postpaid

\section{Endive or Winter Lettuce}

One ounce will sow 150 feet of row.

EXTRA CCPLED. One of the most refreshing of all autumn and winter salads. May b. grown any season of the year, but is more generally used late in the fall. Blanched by tying up the leaves in a conical form for about 10 days before using. Dr. Finck. an authority on foods, recommends it as a food for persons suffering from indigestion. Pkt., 8c; oz., 15e; $1 / 4$ lb., 40c; lb., $\$ 1.25$, postpaid.

SELF-BLANCHTNG. An improved strain of Extra Curled that does not need tying up. Pkt., 10c; oz., 20c; $1 / 4$ lb., 60c; lb., \$2.00, postpaid.

BROAD LEATED BATAVAX OR ESCAROLLE. Foliage broad and flat - deep green leaves with thick midrib, that is exceedingly palatable when w ll blanched. Stands dry weather better than any other sort. We believe this variety is unsurpass d for salad when blanched by an experienced gardener, but is more genorally used cooked like Kale or Spinach or as flavoring for soups, stews, etc. Pkt., 8c; oz., 15c; $1 / 4$ lb., 40c; lb., $\$ 1.25$, postpaid.

\section{Finocchio or Florence Fennel}

A delicious vegetable which should be more largely grown. It is extensively used as a salad in some parts of Europe, and is particulariy palatable when served boiled, with a cream dressing. Very distinct from Sweet Fennel; given the same general cultivation as celery, but requires less blanching. The flavor is somewhat like celery, but sweeter. Pkt., 10c; oz., 25e; 1/t lb., 75e, postpaid.

\section{Garden Huckleberry}

Grows from seed the first year. A new fruit that cannot be excelled for Pies and Preserves. It is very prolific, yielding an immense crop of fruit. It is an annual and must be planted each year from seed. Grows and thrives in all climates and on all linds of soil. The fruits grow larger than the common Huckleberry or Blueberry and will remain on the plant two months after they are ripe. If cooked with apples, lemons or anything sour. they make the very finest jelly. You will be delighted and astonished with this easily grown and wonderful novelty. Pkt., 10e; 3 pkts. 25e; 7 plits., 50c; oz., \$1.00, postpaid.

\section{Improved Yellow Ground Cherry}

Each year this little fruit is becoming more popular. They grow on almost any soil, are easily raised, and are prolific bearers. For sauce or pies they are excellent. They are delicious as preserves, and when dried in sugar, are as good as raisins for cakes and puddings. The fruit is of handsome yellow color, and will keep nearly all winter if stored in a cool place. No one, after raising them once, will ever make a garden without devoting a portion to the Ground Cherry. Be sure and get the Improved Yellow. Our seed is the genuine. Pkt., 10e; 3 pkts., 25c; oz., 50c, postpaid.

\section{Ground Almonds}

The Ground Almond, or Chufa, has a fine flavor, resembling the Coconut or Almond. The meat is snow-white, covered with a thin shell or skin of brown color. It grows close to the surface. Is very prolific, a single nut yielding from 200 to 300 nuts in a hill and will do well in any kind of soil. If the nuts are planted in the spring the same as potatoes a big crop can be expected about potato harvest time. They grow so rapidly and produce such immense crops that you will be surprised. Plant some for the children. Everybody likes them. Pkt. 10c; 3 pkts., 20c; $1 / 2$ lb., 40c; lb., 75c; 3 lbs.. \$2.00; 10 lbs., \$5.00, postpaid

\section{Leek}

One ounce of seed to 100 feet of row.

BROAD AMmRicAx FLAG. The finest variety grown; very hardy. Best for winter and spring use. Mild and sweet. Pkt., 10c; oz., 20c; 1/4 lb.. 60c; lb., \$2.00, postpaid.

\section{LUFFA, a Delicious Chinese Vegetable}

LCFFA ACCTANGCLA (Edible Eisheloth Gourd). Known to Chinese as Singkwa. The fruit is eaten when young, being cooked like Squash, Egg Plant or Asparagus, or served in soups and stews. The young fruit is sometimes sliced and dried. Culture is the same as for cucumbers and melons. Pkt., 10c; 3 pkts., 25c, postpaid.

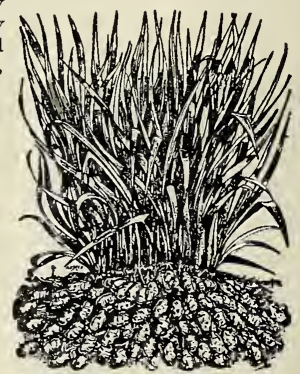

Ground Iimonds

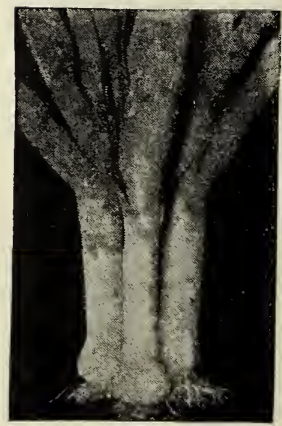

American Flag Leek 


\section{Burgess' Choice Lettuce}

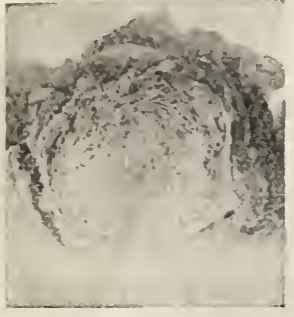

Big Busion Lettuce

One ounce will sow 125 feet of row or produce about 3,000 plants. 4 pounds to the acre.

BEEFSTEIK. One of the best varieties for the home garden. Dors not form tightly folded heads, crimped leaves are highly colored brownish-red; and stands a long time without going to seed. BIG FOSTON. The best head lettuce for forcing under glass. and one of the best for outroor planting. Produc s large. solid heacis. often 10 to 12 inches across. Ercellent quility. sure to bead.
Pikt., 8c; oz., 15c; $1 / 4$ lb., $45 \mathrm{c} ; 1 \mathrm{~b} ., \mathbf{s 1 . 5 0 ,}$ postpaid. BIACK SEEDED SIIPSON. The most popular

\section{Burgess' Celery Lettuce}

Burgess. Imnrored Cos or Calery Iettuce is an entirely distinct trpe of let tuce and is rapidiy gaining tor. Tha plarts are of erect growth forming a slightly oblong bunch oi large crisp ieares. The outer leaves should be gathered together at the top and loosely tied with a piece of soft string for several days befor wanted fcr use. This blanches the inner leaves to snowy whiteress and brittle crispness. BCRGESs MiPRoven is the best rariety. always sweet and tender and of the best quality, eren when grown during the hut summer months. Pkt., 10e; oz., 20c; 14 ib., 6uc; lt., si.uv, postpatd.
CALIFORNIA CREAII BCTTER. Large solid heads; rich and buttery. Grown extensively in the South. Plit., 8c; oz., 15c; 1/4 lb., 45c; lb., \$1.50, postpaid.

GRAND RAPIDS FORCRTg. The best loose-leaved sort for forcing under ginss and on for outdoor planting. Pkt., 8c; 0z., 15c; 1/ lb. $45 \mathrm{c} ; 1 \mathrm{~b} ., \$ 1.50$, postpaic.

\begin{tabular}{|c|}
\hline \multirow{2}{*}{ MAI KNG. The ear } \\
\hline \\
\hline $\begin{array}{l}\text { MAT KNG. The earli } \\
\text { ead lettuce grown. } \\
\text { ellent quality. Plit., } \\
\text { z., 15c; 1/4 ib., } 45 \mathrm{c} \text {; } \\
\text { 1.50. postpaid. }\end{array}$ \\
\hline $\begin{array}{l}\text { By maling up } \\
\text { order for a totai o } \\
\text { pounds or more of } \\
\text { rou can buy at } \pi \\
\text { sale prices. For } \\
\text { particulars see pas }\end{array}$ \\
\hline
\end{tabular}

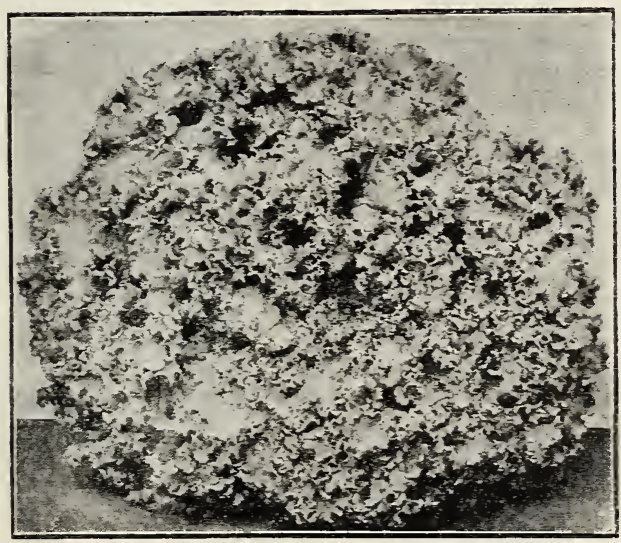

Beefsteak Lettuce

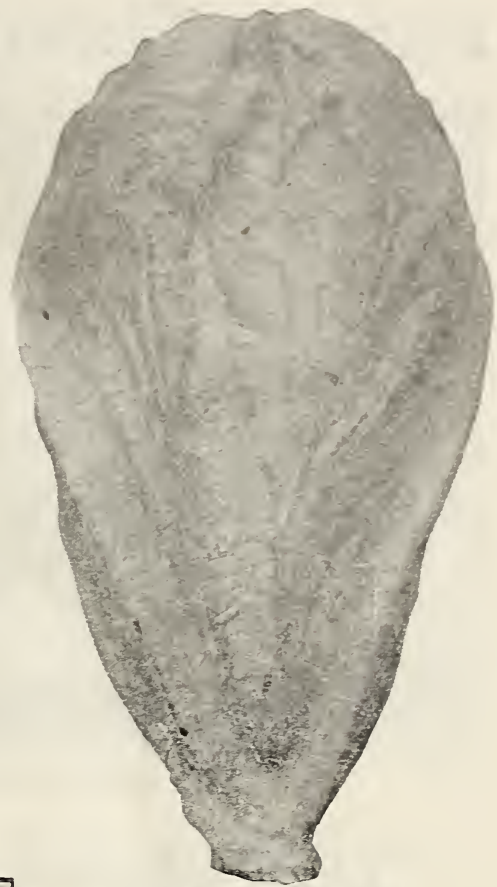

Burgess' Celery Lettuce

\section{Get Rid of Moles}

\section{Los Angeles Lettuce}

The greatest head lettuce erer introduced, and furnishes fine crisp lettuce during the hot summer months. The largest variety grown, often producing heads weishing more than 2 pounds each, nearly as solid as a cabbage, and inside leares blanched to beautiful creamy-white. Stancs shipping as well as cabbage and remains in condition longer than other sorts. The most crisp and tender head iettuce grown. Plst., 10c; oz., 25c; 1/4 lb., 50c; 1b., \$2.25, postpaid.

\section{Chicken or Rabbit Lettuce}

The best green feed for chicisens or rabbits. In this new variety you will find a feed that yields as much or more than other grcen feeds. It is economical to grow, for when cut it resumes its growth rapidly and can be cut again and again; or the leaves can be pulled off each stem like the Jersey Kale. The yie:d is extremely heavy. Chicken or Rabbit Lettuce is too coarse for a table variety. Grows 3 to 4 feet high and just loaded with large leaves. Pkt., 10c; oz., $30 \mathrm{c}$; 1/4 lb., $90 \mathrm{c}$; lb., \$3.00, postpaid.

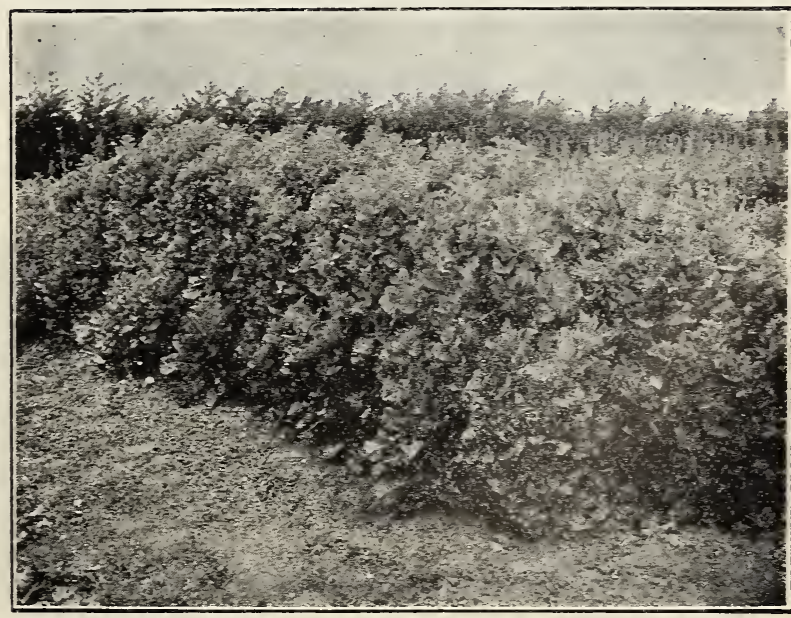




\section{Burgess' Michigan Grown Muskmelon Seed}

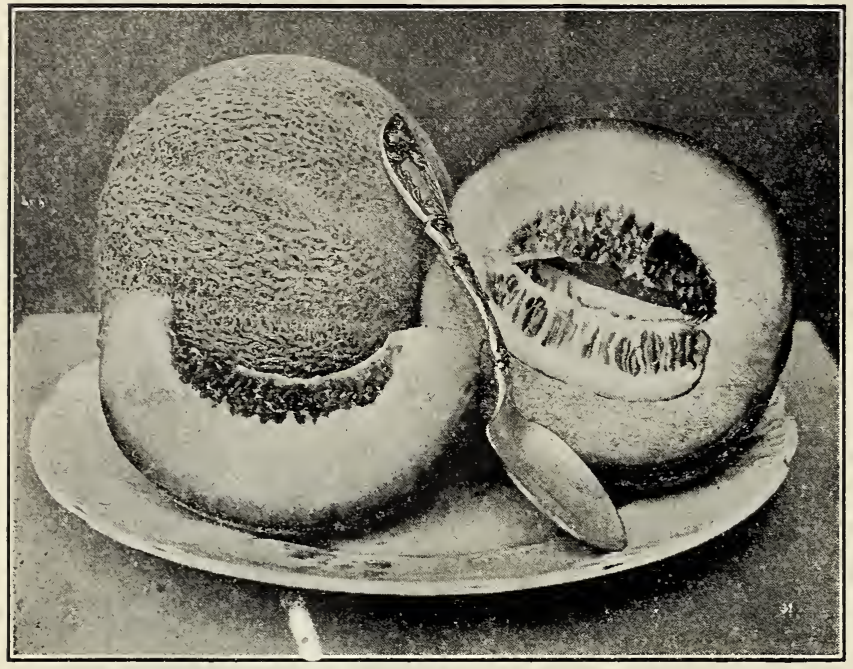

Hearts of Gold

One ounce of seed for 50 hills; 3 pounds per acre. There are many localities other than Michigan in which excellent Muskmelon seed is produced but none that combines the excellent quality with the extreme earliness that our Michigan grown pedigreed seed does. The assurance of a big crop of melons of best quality, and ready for market a few days ahead of melons grown from seed produced elsewhere, is of the very greatest importance to the market grower. You can order your Muslimelon seed from us with the assurance that better seed can not be secured anywhere.

\section{Hearts of Gold}

The Hearts of Gold Muskmelon was first of fered planters but a few years ago, and owing to its superior quality has rapidly taken first place in all localities where it has been introduced. This variety has been grown extensively in Michigan for the past five years and now stands at the top of the list as a shipper. It is just the right size so it may be served in halves. Average weight $1 \frac{1 / 2}{2}$ to $1 \frac{3 / 4}{\mathrm{lbs}}$. Flesh deep orange, extremely thick, fine grained, of the very best quality and very sweet and melting. You will make no mistake in planting this variety. It is a money malker for market gardeners and few, if any, are its equal for the home garden. It is a marvel of productiveness. Ripe fruits in 75 days. Pkt., 10c; oz. 15e; 1/4 lb., 45c; lb., \$1.50, postpaiu.

\section{Lake Champlain the "Money-Maker" Melon}

\section{The Earliest Muskmelon of Good Quality}

Our Michigan grown seed of this variety produces ripe Pruits in 57 to 60 days from date the seed is planted in the field, bringing your crop ahead of competitors and netting you the top mirlset price. The Cornell Eniversity Experiment Station reports this melon to be much earlier than any other in their very extensive trials. It is not onlv the earliest Muskmeion of good quality. but it is so good that Professor Tompson of the Massachusetts Agricultural College reports it as the best in quality he has ever eaten. The flesh is deep, very sweet and melting. of golden yellow color; a small round melon; nicely netted. The plant is very vigorous and heaitby, setting and ripening melons even under adverse conditions. It is not a long distance shipping melon, but will give you the earliest quality melon for the local market, and net you more profit than any other Muskmelon grown. From a half-acre patch, 986 halfbushel baskets were sold at $\$ 1.00$ per basket, making a gross profit of nearly $\$ 2.000 .00$ per acre. Plst., $10 \mathrm{c}$; oz. 20c: $1 / 4$ lb., 60c; lb., $\$ 2.00$, postpaid.

\section{Bender's Surprise}

\section{The Best Large Size Muskmelon}

Exquisitely fine flavor, large size and medium earliness combine to make this new melon a great favorite. Melons average quite large, many weighing 10 pounds or more; oval in shape; iight green with coarse netting, and turn a

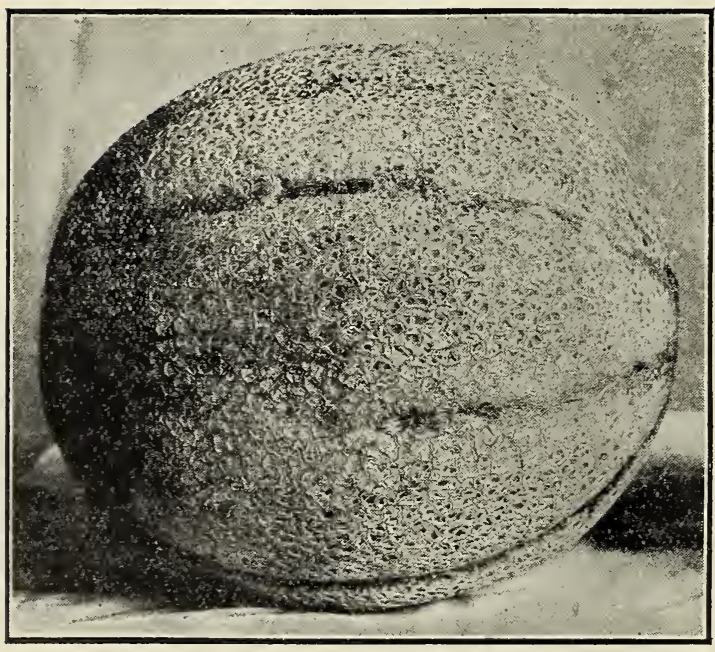
golden tint as they mature. Flesh deep orange, very thick and deliciously sweet. Will keep in good condition a week after picling, and actually improve in flavor during that time. The flesh is so firm and thick that the melons remain firm and in gool condition much longer than any other large melon of this class. For market and shipping this is an important consideration. We do not know of any other large Muskmelon quite equal to the Bender for either the market or the home garden. Pkt., 10c; oz., 15c; $1 / 4$ lb., 45̃c; lb., \$1.50, postpaid.

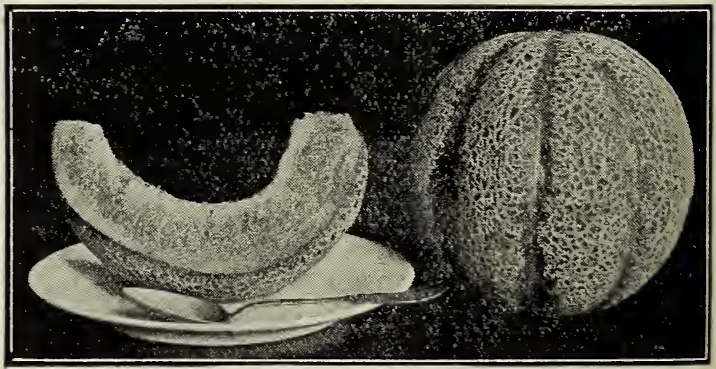

Lake Champlain 


\section{Hale's Best Muskmelon}

\section{The Earliest Variety Grown}

Hale's Best is a larger melon than Lake Champlain, and probably two or three days earlier. In fact. We consider it the earliest melon grown. It is not a nelon of high quality, but it is a wonderful seller and a great money maker. It is a melon that can b shipped clear across in the best of condition. While it is a melon of recent introluction. the probabilities are that more of this variety was grown last yar by the large western melon growers than all other varieties combined. This is due to the fact it is the most profitable varieiy for them to grow. If you are growing melons for the marliet, you shouid plant liberally of this me.on. salmon flesh. Pkt., 10c; oz., 15c; 1/ lb., 45c; lb., \$1.50, postpaid. OHIO STGAR, or Green Fleahed 0 age. Nearly all who have tried it pronounce it the best of ail gr,en fleshed melons. It is one of the sweetest and most luscious cantaloup s now on the market. Of
desirable size, round. inclined to oral in shapo. distinctly ribbed and thickly netted: color of shin gray-green. Because of its firm flesh and solidity. it is a splendid shipper. Seed cavity small. The flesh is an attractive green of fin z texture, sugary, juicy and tender. Plit., 10c; oz., 20c; 1, lb., 55c; 1b.. \$1.i5, postpaid.

OSAGE, or MILLER'S CREAM. The most popular mair. crop variecy. 1 ruits medium in siz. salmon fiest. thick. fine graine and highly flavored. A good shipper, and always in demand. Our
Michigan seed produces ripe fruits in 75 days. Pkt., 10c; oz., 20c; it lb., 5̃e; lb.. \$1..5, postpaid.

ROCKI FORD. The most famous Muskmelon. Melons nearly round and uniform in shape and size. Flesh light green. very deep, ripening clear to the rind. D licious. delicate spicy flavor. Plit., Sc; oz.: 1?c; i. lb., 35c; 1b., \$1.00, postpaid.

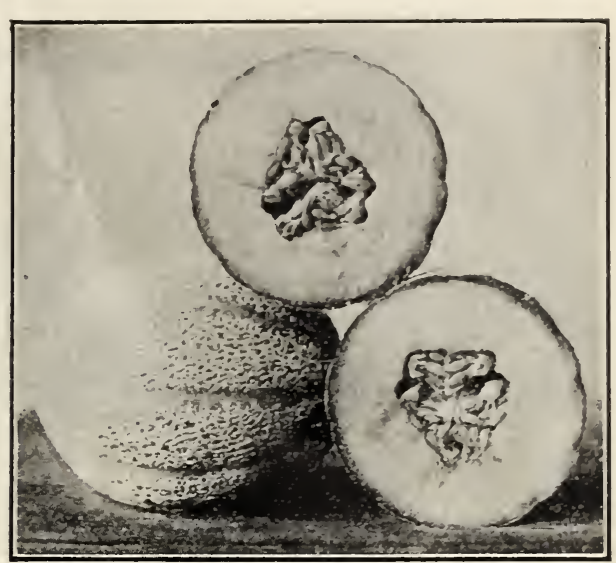

Hale's Best

FXTR.A E.APLY H.ACKENGACK. Tlos best early gre $n$ flcshed muskmelon and one of the hardiest and most prolific. Ripe fruits in 65 days-fully 10 dars ahead of the well known old Hacliensack.
Fruits round, flattened at the ends, irregularly ribbed and heavily netted. Flesh green, thick, of excellent quality and flavor. Melons are of good size, weighing from 5 to 10 pounds each. Plt., 8c; oz., 1Jj; $1: 1 \mathrm{~b} ., 40 \mathrm{c}$; lb., \$1.25. postpaid.

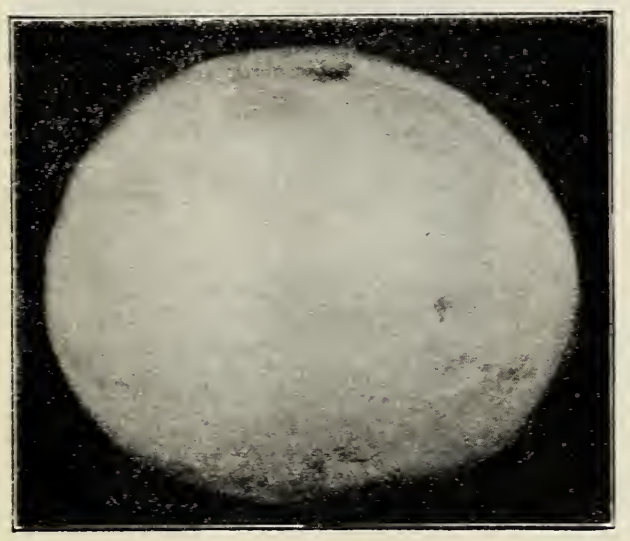

Honey Dew Yelon

\section{Banana Muskmelon}

This melon surpasses all others in its delicious fragrance. The flosh (the melon being nearly solid) is of a rich salmon. The quality is excellent when the melon is thoroughly ripe. It grows from 18 to 36 inches in length, and is very prolific. It looks almost like an overgrown banana and smells like one. Has a flavor all its own. Very sweet and delicious. Don't fail to try it. Pkt., 10c; oz., 15c; 1/4 lb., 45c; lb., \$1.50, postpaid.

\section{"Honey Dew," the Famous Melon}

This new frut is a cross between the Eocis. Foril Cantoloupe and a South Sea Island Casaba and has retained all the best qualities of both and is better than either. The melon is nearly white, turning to lemon-yellow when ripening. and the arerag size is a little and sweetest Muskmelon and luscious in flavor. The rind is hard. It is good as soon as picked off the vine and will keep good for months if kept in a cool, dry place. It is therefore a good shipper and a most splendid fruit to grow for the market. One prominent shipper is urging melon growers to plant largely of the Honey Dew, saying it would put the Rocky Ford Cantaloupe out of business. In the city markets the Honey Dew sells at higher prices than any other melon, and there is every reason to believe that as soon as the productiveness, unsurpassed quality and shipping characteristics of Honey Dew become generally known it will become a standard variety and every gardener will grow it. As a local melon, it advertises itself. The fist one eaten creates a desire for more. Plent it in your home garden. It will afford you more pleasure than any other vegetable you have. Pipe fruits in 90 to 120 days, depending upon the season. Full grown fruits that do not ripen vines before the fall frosts. can be picked and will ripen in storage. Pkt., 10c; oz., 20c; 1/4 lb., 55c; lb., \$1.75, postpaid.

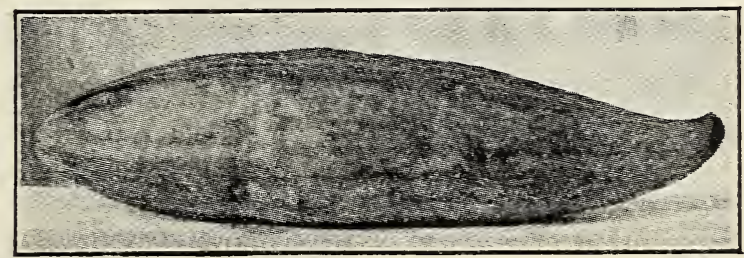

Banana Muskmelon

\section{Vine Peach}

In the West and Northwest. Where fruit is scarce. the Tine Peach is becoming popular. It is easily cultivated. wonderfuliy prolific, and can be used in every way in which you would use a peach, except that it is not usually liked raw. The rine on which they are borne is somewhat similar to the muskmelon vine, and requires the same cultivation. The fruit is about the size of a large peach, and is of a bright orange yellow color, somewhat russety.

A jar of these cut in halves and cooked in syrup presents a beautiful and tempting appearance. Plit., 10c; 0z., 25c, postpaid.

\section{INCREASE CROPS}

and produce better fruits and regetables by using Fertil-N (Fertilizer Extract). Read about it on page if.

WHOLFSAIE PRICES Direct to the Planter. If you can use 10 pounds of seed (a total of ten Wholesale Prices. Read about it on page 76 . Notice wholesale prices on pages 76 , $i 7$, and 75 . 


\section{Michigan Grown Watermelon Seed}

Plant Michigan Grown Watermelon Seed for Early Maturity. Be First on the Market. Northern seed is adapted to all climates and is the best for both the Northern and the Southern planter, because it has been inatured in a short season and will grow hardier plants and earlier melons than Southern seed. We sell thousands of pounds of Watermelon seed to Southern planters who grow early melons to ship Nonth. The fact they continue planting our seed each year, and pay more for it than they would have to pay for seed grown in their own locality, should be proof that our seed is worth more. A few days earlier maturity means considerable to both the Northern and the Southern market grower. one ounce of seed for 25 hills; 4 pounds per acre.

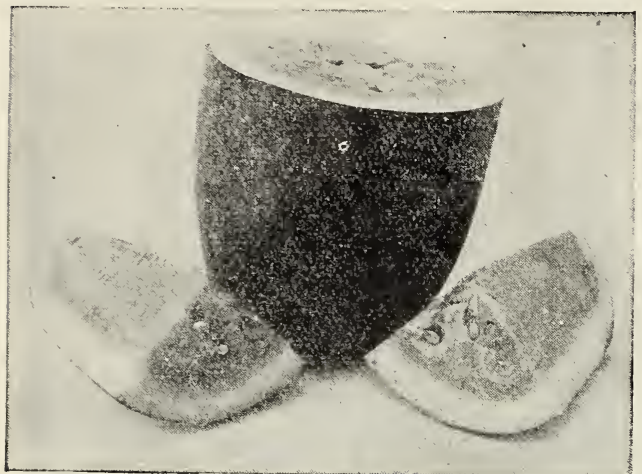

Tom Watson

PEERLESS. The earliest large long Watermelon. Our strain of this wonderful melon ripens about 10 days later than Pride of Yukon. For the Central and Northern States, we consider this the best general cropper for the home market; has too thin a rind for shipping unless packed in straw. Fruits larger than Halbert Honey or Kleckley's Sweet and 10 days earlier; rind light gre-n. mottled and veined; flesh bright scar$l \leq t$, solid to the center, tender, sweet, melting and delicious. Few, if any, surpass it for quality or productiveness. Pkt., Sc; oz., 15e; $1 / 4$ lb., 40c; lb., \$1.25, postpaid.

PRIDE OF YIKON. The earliest watermeion grown. See inside back cover of this catalog.

COLE'S EARLY. The leading extra early Watermelon in nearly all parts of the country. Only 5 days later than Pride of Yukon: excellent quality; small in size, but what they lack in size they make up in number. $\$ 1.00$, postpaid.

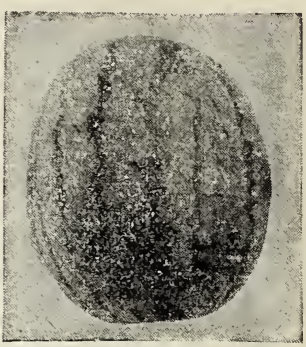

Cole's Early

TOM WATSON. Tom Watson is the most popular of all Watermelons, occupying a very promilent place in all markets, and is everywhere called for. The flesh is superb in quality and of the brightest red color. The handsome, dark gres rind is thin, but hard and tough, so is unsurpassed as a market and shipping sort. The melons are usually 20 to 24 inches in length and 10 to 12 inches through, averaging on good soil over 30 pounds each, and single specimens otten weighing 50 to 60 pounds. A good yielder and a great money maker on all markets. Matures in 85 days. Our Michigan grown seed cannot be excelled. Plit., öc; oz., 12c; 1/4 lb., 35̌c; lb. $\$ 1.00$, postpaid.

KLECIILE'S SWEET or MONTE CRISTO. One of the most if not the most popular melon for the home garden and for nearby markets, because of its superb fiavor and surpassing crispness. No melon sweeter than Kieckley's Sweet. Average length 18 to 20 inches; color very dark green; season medium early. Plit., 5e; oz., 12e; $1 / 4$ lb., 35c; lb., \$1.00, postpaid.

HALBERT HONEY. Very similar to Kleckley's but preferred by many on account of it $b$ ing more pertect in shape. Same length. but not so tapering toward the stem end. Plit., 5c; oz., 12c; 1/4 lb.. 35c; lb., \$1.00, postpaid.

IRISH GRAX. A melon of uniformly large size. closely resembiing Kleckley's Sweet, with the exception of the tough rind which is gray in color. Pipens eariler than Tom Watson and will keep in good condition for a long

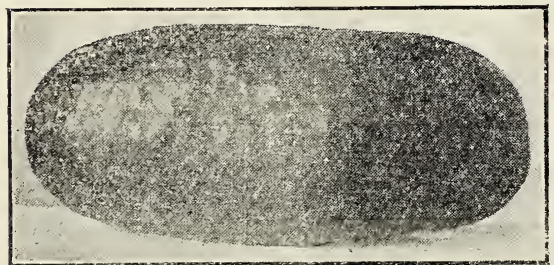

Reariess

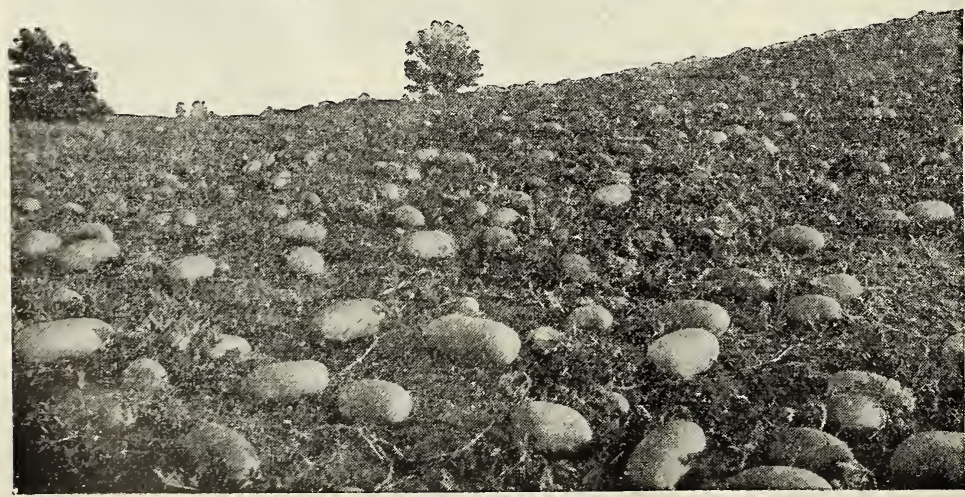

A Field of Irish Gray for shipping; unusually sweet and of best quality. Will 1b., $40 \mathrm{c}$; lb., \$1.25, postpaid. $\$ 2.25$, postpaid.

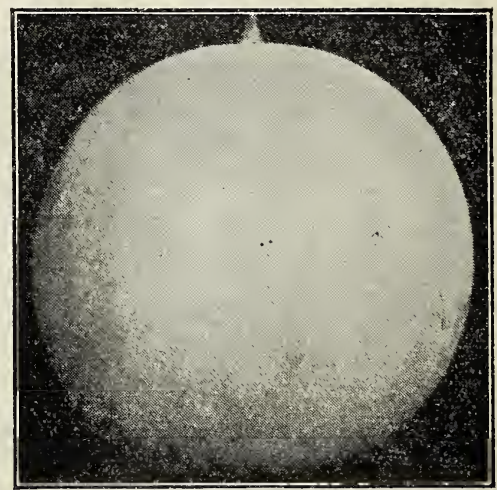

Winter able melons than market-

GOLOEX HONEY. Excellent yellow-fleshed variety. Sweet as honey. Pkt., 10c; oz.. 15c: 1/4 lb., 45c; 1b., \$1.50, postpaid.

COCONCT or CLIMBING. The vine may be allowed to trail on the ground or may be trained and tied to trellis. Melons about the size of a large coconut and of the highest quality. Fruit ripens for a long period, unlike other sorts which ripen their fruit mostly at one time. An ideal melon for the small garden. Pkt., 10c; oz., 25c; $1 / 4$ 1b., 70c; ib.,

CITROY. FIesh white and solid. Used exclusively for making preserves. Pl.t., 5̌c; oz., 12e; 1; lb., 3̧̌e; lb., \$1.00, postpaid.

\section{Winter Watermelon}

A home grown me!on for your Thanksgiving dinner. It is not a citron or a freak, but a very prolific long-keeping true Watermelon. Flesh red, extremely firm, very brittle and deliciously sweet. Fruits talien from the field before killing frost and stored in a cool place will keep long into the late fall and early winter and retain their delicious sweetness and flavor. Plkt., 10c; oz., 15̃e; 1/4 lb., 45̃c; lb., \$1.50, jostpaid. 


\section{New Guinea Butter Vine}

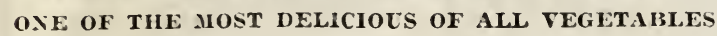

The New Guinea Butter Vine is a wonderful vegetab: It has b en citensively advertised as the Gigantic Guinea "Bean". Grow's to enormous size, one fruit often weighing $15 \mathrm{lbs}$. and from 3 to 5 feet long. It is a member of the edible gourd iamily and in growth is similar to the squasli. and can be grown in the same manner or can be trellisid uv. It is wondersully prolific, more productive than squash and much easier to grow. The vines are always free from disease and insect posts. and stand more neglect and abuse than any other vegetable vine we know of The fruits should be eat $n$ when small. while the fuzz: Erowth is yet on. It can be coolied like Squash, fried lik Erg Plant or pickled like Cucumbers, and when cut up in small pieces and coolied with cream or fried it is mosi delicious. If trellised up, the vines take up so little space, no garden is so small but that room can be found for at least two or three plants. Mrs. Sain J. Yoder, Apple Creek,

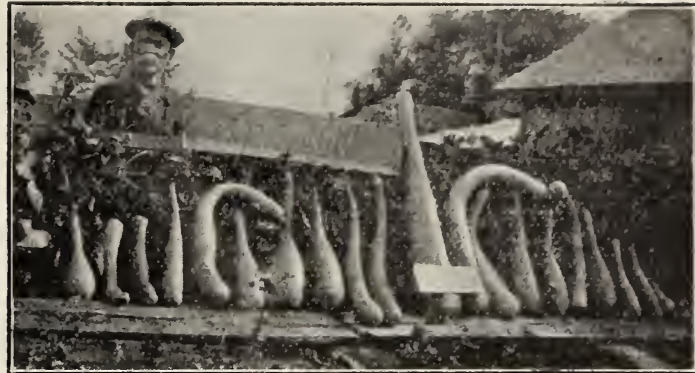

vew Guinea Butter Vine tıuits grown from Burgens' seed by Ir. George Price, Waubaushene, Ont., Canada

Ohio, grew one New Guinea Butter Vine fruit which weighed 15 lbs, and was $41 / 2$ feet in length. Another customer writes that he cut 75 fruits from one vine, and that each fruit was from $21 / 2$ to 3 feet long. Pkt., 10c; 3 plits., 2a*; oz., 50c. postpaid.

\section{Mushroom Spawn}

Each brick of our P'ure Culture IIushroom Spawn contains about 40 cubic inches of spawn. and will plant 10 square feet of bed. Cultura directions free with each order for spawn. 60e per brick; 3 bricks. \$1.50. postpaid. By express, not prepaià, in quantities of six or mor bricks, 30 cents $p$ r brick.

\section{Easy Method of Growing Mushrooms}

A planter in Jinnesota gives the following directions for growing Mushrooms in the awn:

"Break up the brick of spawn into inch square pieces. Have ready some fresh horse manure, and place a trowel full under the sod at intervals about the lawn. Put a piece of spawn on the manure. and replace tho sod. Do this in early spring. After the warm spring rains, the lawn will be full of mushrooms. If th se directions are followed, the size of the crop will bo dependent entirn'r upnn the weather. It is important that the spawn be planted provinus in the early during the summor."

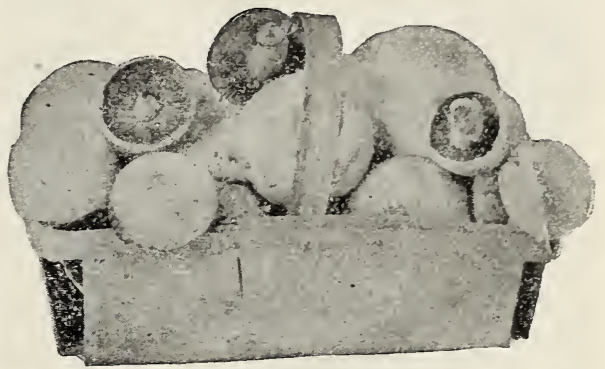

\section{Mustard}

One ounce of seed to is $\mathrm{fee}^{+}$of row.

The large leaves of the tw. first named varieties make a most palatable and piquant type of greens and possess healthful tonic properties. Preferred by many to Spinach, but should be cut roung, for when old the fiavor is strong. Begin sowing seed as early in the spring as the weather permits and make successive sowings every two weeks.

SOCTHERN GIAXT CCPLED. Leaves large, yellowish-gmen. much crumpled on the edges. The most extensively grown of any variety. Ready for table in about 35 days. Pkt., 5e; oz., 10c; 1/4 lb., 25c; lb., j5c, postpaid.

FORDHOOK FANCT. Of v'gorous growth; beautiful dark green leaves which curre outward like fine ostrich plumes. Shoots to seed more slowly than any other Mustard. Pht., Je; oz., 10c; 1/4 lb., 25c; lb., i5c, postpaid.

WHitE LONDox. Seeds white; preferred by housewives for pickling. Pkt., j̃c; oz., 10c; 1/1 lb., 25c; lb., 65c, postpaid.

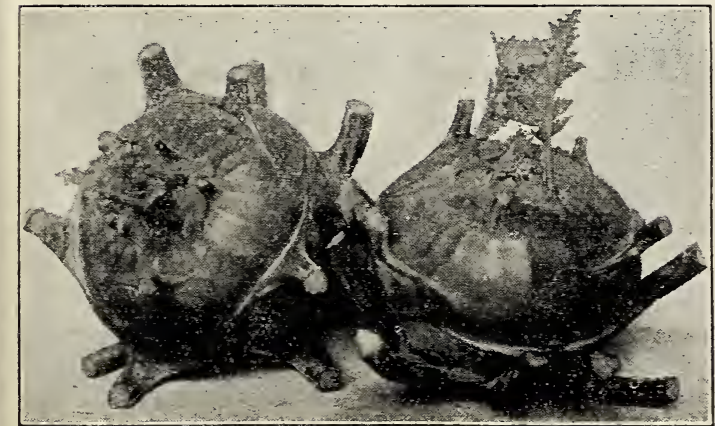

Early White Vienna Kohl-Rabi

\section{Momordica Charantia}

The MoMORDICA CHARANTIA (Balsam Pear) is known to the Chin se as La-kwa. Grown in China for the edible pulpy arils surrounding the seed; also for the edible fruit itself which is prepared, usually by boiling, before it is ripe. Vine grows 10 feet or more. American planters who have tri d it speak highly of it. Try it. Pkt., 10c; 3 pkts., 25c, post paid.

\section{Kohl-Rabi ( $\underset{\text { CABBAGE }}{\text { TLRNIP }}$ ROoTEd}

\section{One ounce of seed to 200 feet of row.}

The Kohl-Rabi belongs to the Cabbage family. It does not make a head but the stalk forms a turnip-shaped swelling just above the surface of the earth. These balls when the size of an egg make a very excellent vegetable. May be cooked either like cauliflower or turnip. resembling cauliflower in fiavor. They are in season during June, July and August, or at periods when turnips are not good, and succeed in dry weather when turnips are fibrous and hot. For a continuous supply sow every 2 weeks up to the middle of July. EARLY WHITE FIENA is the best variety of Kohl-Rabi; very select, extra-early strain; ready for the table in 60 days from se Flesh firm but cooks very tender; sweet and delicious, No garden complete without it. Pkt., 10c; oz., 20c; $1 / 4$ 1b., 60c; lb., \$2.00, postpaid. 


\section{Burgess' Choice Onion Seed}

Onions usually net the grower more money per acre than any other vegetable crop. If you are going to raise a crop that requires the labor and capital that Onions do, don't waste your time cultivating a field of culls. The difference in price, if any, between a good strain of carefully grown seed and a poor strain, carelessly grown, is so small that you can only afford to plant the very best. There are many inferior strains of Onion seed being offered to the public at low prices which will produce Onions of all sorts and sizes instead of the uniform. marlzetable crop cbtained by planting a carefully selected surain of seed. Each year a large and steadily increasing number of market ga:ieners buy our Onion seed because they realize that none is superior. one ounce of seed for 150 feet of row; 4 to 6 lbs. per acre.

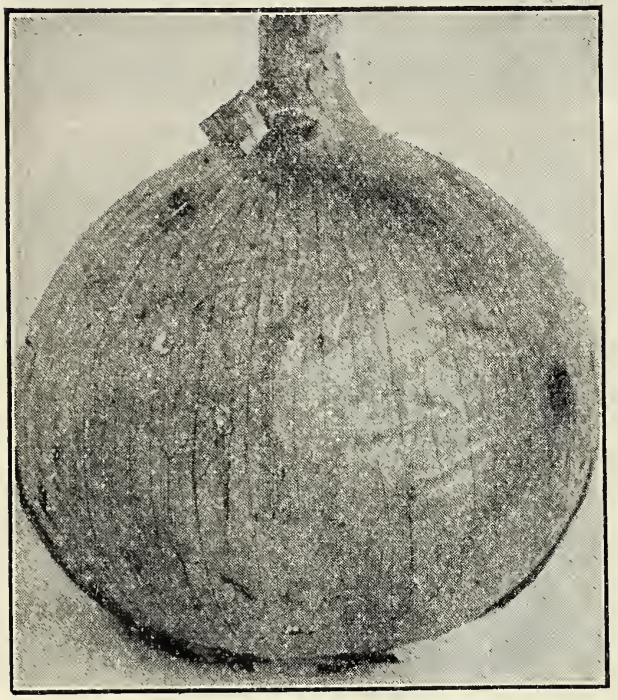

Riverside Sweet Spanish

\section{Save Money on Your Onion Seed}

If you are going to plant a quantity of Onion or other seed, you can save money by taking advantage of the Wholesale Prices, as given on pages 76,77 and 78 of this catalog.

\section{Riverside Sweet Spanish The Largest and Sweetest Onion Ever Grown}

Our Riverside Sweet Spanish or Valencia Onion was first grown in Spain. A small supply of seed was secured and planted in this country, and we are now able to offer it to our customers. In general color and shape it resembles Prizetaker, but is a distinct type, and will average better than twice the size of Prizetaker. Although of gigantic size, it has a small top, is an extra good keeper, and if allowed to thoroughly dry, will stand shipping long distances. It is globe-shaped; the shin light yellow or straw color; the flesh pure white, of very fine grain, crisp, juicy and exceptionally mi'd and sweet. We are anxious that our customers give this wondorful onion a trial, for it is sure to give the very best of satísfaction. Plit., 10c; oz., 35e; 1/4 1b., \$1.00; 1b., \$3.50, postpaid.

IARGE REN WETHERSFETID. The standard main-crnn flat red variety. Pkt., 8c; oz., 20c; $1 / 4$ lb., 60c; lb., \$2.00, postpaid. MAMMOTH SILVER KING. The largest white Onion. Unsurpassed for tenderness and very mild. Plit., 10c; oz, 30c; $1 / 4$ lb., $90 \mathrm{c} ; 1$ b., $\$ 3.00$, postpaid.

PRIZETAKER, or MAMMOTH SPANISH. The big yellow variety you see for sale in the fruit siores. It is an excellent keeper, a handsome Onion of perfect globe shape and enormous in size, many single Onions having been raised to weigh more than five pounds. The flavor is very plsasant, mild and sweet. Plant the seed early and you can easily grow these large, sweet, mild, juicy Onions. We have an extra select strain of this varietv. Be sure to get the genuine. Pkt., 8c; oz., 25e; $1 / 4$ lb., $10 \mathrm{c}$; $1 \mathrm{~b}$., $\$ 2.25$, postpaid.

SOUTHPORT RED GLOPW. The hest round red Onion. Pkt., $8 c$; oz., 25c; $1 / 4$ lb., 75c; lb., \$2.50, postpaid.

SOCTHPORT WHITE GLOBF. Fxtra select: the best round white Onion. Always brings a fancy price on the market. Pkt., $10 \mathrm{c}$; oz., 30c; $1 / 4$ lb., 90c; lb., $\$ 3.25$, postpaíd.

SOCTHPORT YELLOW GLOBE. The favorite round yellow Cnion with the big Onion growers. Attractive in appearance and an immense cropper. Pkt., Se; $\mathrm{oz}, 25 \mathrm{c} ; 1 / 1 \mathrm{t}$ lb., 70c; lb., $\$ 2.25$, postpaid.

WHITE PORTCGAT or SILVERSKIN. The standard flat white Onion; bu:bs grow to good size; mild and of fine Aavor Grown extensively for winter use and for sets and pickling Onions. For sets or pickling size. sow $1 \mathrm{lb}$. of seed to each 100 feet of drill. Pht., 10e; oz., S6e; $1 / 4$ lb., 90c; lb., $\$ 3.00$, postpaid.

CRYSTAL WAX BERMUDA. The most attractive onion in the world. Absolutely pure white. Many car loads of these flat white onions are grown annually in Texas and shipped North for early spring use. Also does well in the North. A rapid grower; very sweet and mild. Pkt., 10c; oz., 35e; $1 / 4$ lib., $\$ 1.10$; lb., \$3.75, postpaid.

EXTRA EARLY BARLETTA. Tery small white pickling Onion. Pkt., 10c; oz., 30c: 1/, lb., $90 \mathrm{e} ;$ lb., $\$ 3.00$, postpaíd.

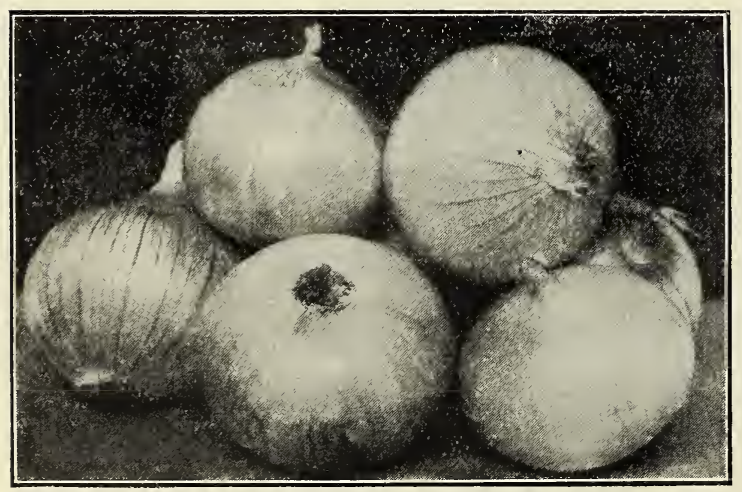

\section{Ebenezer or Japanese Onion}

This is the mildest flavored Onion grown. The fiesh is white, firm and of a very delicale tlavor. The unions are quite similar to Yellow Globe Danvers in shape but much larger in size, yellow skinned and have very small tops and mature early. Many people who know this Onion will have no other kind for their own table. In the localities where it has been grown, the Onions of this variety command much higher prices than other kinds. Those who want a nice mild Onion, either for large Onions or bottom sets, would do well to try the Ebene..er. Sets are grown the same as large Onions, except that the seed is sown thickly-one pound of seed to each 100 feet of drill. These sets, if planted early in the spring. will produce ripe Onions in July, at which time thev will bring a high price. Sets of this variety rarely produce seed stallis as other kinds do. The Ebenezer is such a goor keeper that even those ripening in July will keep sount and hard through the fall and all winter. Don't fail to plant some Ebenezer Onion seed this season, sowing some for large Onions and some for sets. For price of genuine Ebenezer sets, see page 21. Pkt., 10c; oz., 30c; $1 / 4$ lb., 90c; lb., $\$ 3.25$, postEbenezer or Japanese paid. 


\section{Australian Brown Onion}

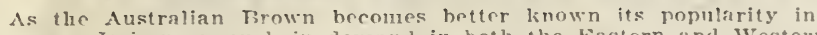

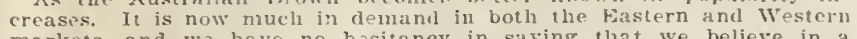
markets, and we have no hesitancy in saying that we believe in a comparatively short time it will be one of the most popular of all
market onions. It is of semi-globe shape, brownish-yellow in color. solid, white flesh and very mild and sweet. The Onions grow to a fair size and ripen evenly and without a neck. This begin to form a bulb very yuickly and reach maturity in a remarkably short time. It qualities, hiving b.en kipt in fine condition for a year after harvest. Ve consider it by fir tlie best union for sections where the season is short, and a most desiruole variety for all climates. It is one of the best of all. Onions for bottom sets, fine ior little green Onions from seed. and for ripe Onions for cooking there is nothing better. Plit.. 10e; oz., 20e; 1/4 lb., 5je; lb., \$1.75, postpaid.

YELIOW GLOBE DINTERS. The most popular yellow Onion. Not (skt, 8e: oz. 20e: $600: 1 b .82 .00$. postpaid.

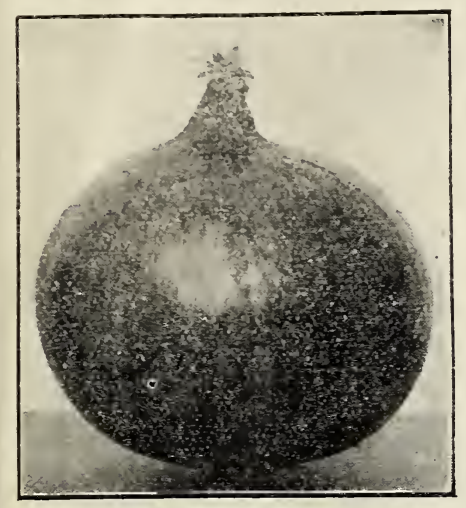

Australian Brown
FARLY TMITE TELSI. The first variety to be ready for green onions in the Spring. bulbs, is perfectly hardy, and mild and of excollent quality Market gardeners find it xtremely profitable, as it makes a most atractive bunch eady tor the market. Pkt., 10e; oz., 30c; 1/4 ib., 90e; lb., .60, postpaid.

\section{Japanese Long Bunching Onion}

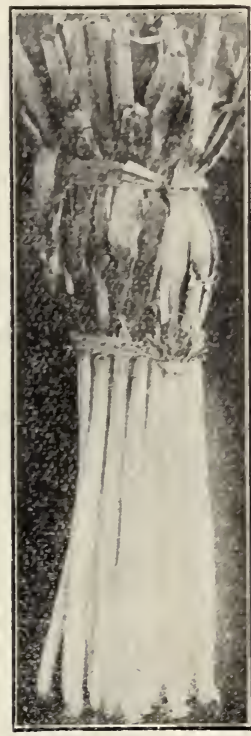

Japanese Long
A valuable introduction from Japan which, on account of its merit, is sure to meet with popular favor for soung green onions. It forms no bulb, but produces a long white tender root as shown in the illustration. It is very mild and sweet, and owing to cluality and fine appearance. it makes an attractive bunch that sells at an advanced price over other varieties. Our Japanese grower informs us that in Japan this Onion is often blanched 24 inches. With this variety you can have bunching onions of the very best quality all through the summer. No garden is complete without a row of these onions. A money maker for market gardeners. Pkt., 15c; 2 pkts., 25c; oz., 50e; $1 / 4$ lb., $\$ 1.50 ; 1 b ., \$ 5.00$, postpaid.

\section{Bottom Onion Sets}

One quart of sets for a 50 foot row; 10 to 12 buskels per acre.

Dottom Onion sets are the product of seed and the little bulbs are planted for Green Onions. or to produce large Onions for eariy market. They produce Onions ready for the market or household use 1 to 6 weeks earlier than can be done by: sowing setd. The planier is enabled thereby to get highest market prices for his early Onions grown frcm sets, aiso permitting the growing of another crop on the land the same ycar. Piant every ten days, beginning as eariy in the spring as the ground can be worked. for a succession of Green Onions for the table. The sets we hance sull siz and should not be confused with the cheap unreliable kinds so often offered for sale.

IELLOW BOTTOI SETS (Genuine Ebenezer or Japanese). Make sweet and mild Green Cnions and big stweet Onions that will izeen all winter. Try them once and rou will never use any other varietr of vellow sets. Pint, 25c; quart, 40c; 4 qts., $\$ 1.40$, postpaid. By express, not prepaid, \$1.25 per peck.

WHITE BOTTOY SETS. Pint, 25c; quart, 45e: 4 gts., \$1.60, postpaid. By express, not prepaid, \$1.45 per peck.

Prices of Onion Sets are subject to fluctuations of the market. The price per pint, quart, 4 dwarts and peck will hold good throughout the season, or as long as our stock lasts. Write for prices on larger quantities.

32 lbs. of Onion S:ts constitute a bushel.

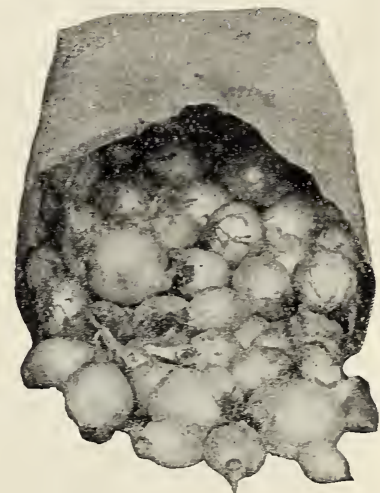

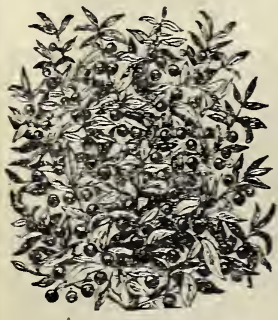

Orange Sunberry

\section{Okra, or Gumbo}

One ounce of seed to 100 feet of row.

MIPRONED WHITE VELTET. The best variety. Popular in the South Yorthern gardeners make a great mistake in not planting some of this delicious regetable. Sixty days from planting to maturity. Pretty Hibicus-like flowers, followed by seed pods which are fine for soups and excellent when stewed. Pkt., 5c; oz., 10c; 1/4 lb., $25 c ; 1 b ., 75 c$, postpaid.

\section{Orange Sunberry}

A new berry about the shape and size of the Gooseberry; a beautiful, bright orange coior when ripe; mild in flavor, not sour. It is an annual that is grown from seed, and fruits in the late summer and fall. Will grow anywhere; very productive, and fruits will remain on the plants 6 or 8 weeks after they are ripe. Fine for jelly, jams, pies and preserves. Pkt., 10c; 3 pkts., 25c; 7 pkts., 50c, postpaid.

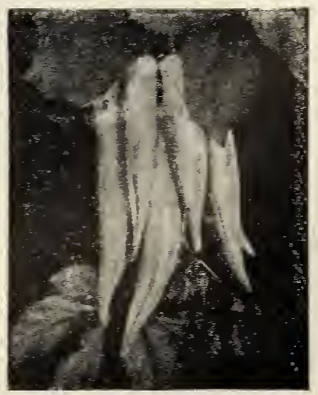

Imp. White Velret Okra 


\section{Burgess' Northern Grown Peas}

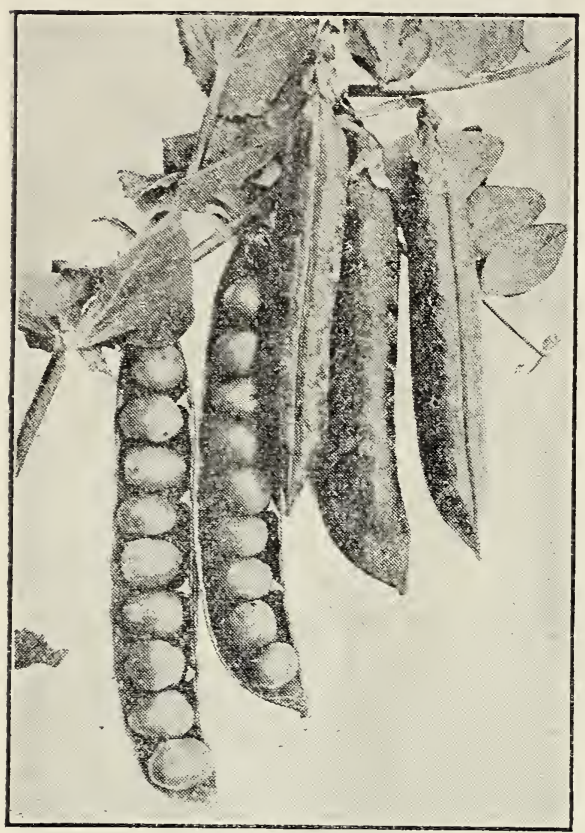

Burgess' Drought-Proof
Burgess' Drought-Proof Pea

\section{Laughs at Drought, Smiles at Rain}

Burgess' Drought-Proof will do well under a wider range of weather and soil conditions than any other variety. It will grow a crop during the driest, hottest summer months, at a time any other variety would be a failure. In the hot, dry localities of the West this variety will grow a large crop without irrigation and without a single drop of rain falling upon it from seed time to harvest. For mid-summer or late summer planting this is the variety to plant. If it rains and the soil is kept moist this variety will produce as large a crop as any variety we know of: if it doesn't rain. and it gets hot and dry, you will get a crop anyway. The handsome round pods are well filled with from 7 to 10 peas in a pod; quality excellent. sweet and tender. even when the peas are large. Vines grow 2 feet high, and require no support. This is the pea that will do its best in the North, South, East or West. Don't fail to give it a trial. Pkt., 10c; $1 / 2$ lb., 30c; lb., 55̃c; 2 lbs., \$1.00, postpaid.

ALASKA. Our strain of this variety is the earliest Pea grown. Exceedingly productive. cen be planted as sonn as ground thatws out in the spring. Height $2 \mathrm{ft}$. Pkt., 10c; $1 \frac{1}{2} \mathrm{lb}$., 22c; lb., 40c; 2 lbs., 70c, postpaid.

AMERICAN WONDER. $\cap$ ne of the finest ear'y Peas: erceedingly dwarf, only 10 to 12 inches tall, and a few days later than Alaska. Pkt., 10c; 1/2 lb., 22c; lb., 40c; 2 lbs., r0e. postpaid.

IITTLE MARVEL. The earliest wrinkle Pea, and the most productive extra-ear! wrinkled variety. Vines grow 15 incho high and are heavily set with well-fills. pods. Pkt.. 10e: 1/2 lb., 25e: lb.. 45e; 2 lbs.

POE PIITM GFM. (Improved Little Gem) One of the most popular early varieties: height 12 to 15 inches and very productive. Same season as American Wonder; only 2 or 3 days latny than Litte MIrrvel. Plit. 10c; $1 / 2$ lb.. 2.e; lb., 40c: 2 lbs., 70c, pos paid.

GRADTS, or PROSPERITY. A popular variets with market growers who demand both earliness and quality. Vines $21 / 2$ feet tall and bear an enormous crop. Pods 33 to 4 incics
in length, containing 6 to 8 large sweet peas. Plit., 10c; $1 / 2$ lb., 22c; lb., 40c; 2 lbs., $70 c$, postpäicl.

THOMAS LAXTox. Only a few days later than American Wonder and Premium Gem, but pods and peas much larger. Unsurpassed than American Similar to Gradus, and even better. Pkt., 10c; 1/2 1b., 22c; 1b., 40c; 2 lbs., 70c, postpaid.

HINDPEDFOLD. This Pea may be described as an improved Laxtonian. which it resembles very much. Pods $3 \frac{1}{2}$ to 4 inches long and well filled with large deep green Peas of finest guality. Vines 16 to 18 inches. Peas mature only a few days following Thomas Laxton. Pkt., $10 \mathrm{c} ; 1 / 2$ lb., $25 \mathrm{e} ; 1$ b., 45e; 2 lbs., 80e, postpaid.

LAXTONiA. Same season as Hundredfold; vines 15 to 18 inches; peas of superb quality and large size and 8 to 10 in a pod. Pkt., 10e; $1 / 2$ lb., 25c; lb., 45c; 2 lbs., 80c, postpaid.

HORSFORI'S MAIIET GARDEX. The most productive scond-early or main crop variety; about a week later than Laxtonian; and a most profitable variety for market gardeners. Excellent quality; height 2 feet. Plkt., 10c; $1 \frac{1}{2}$ lb., 22c; lb., 40e; 2 lbs. 70c, postpaid.

TELEPHONE A leading mid-season variety and very ponular with mnrfot gardeners whose trade appreciates fine appearance and high quality. Pods $41 \frac{1}{2}$ to 5 inches long and filled with large peas which are tender. sweet and of excellent flavor. Height $31 / 2$ to 4 feet. Pkt.. 10c: 1/2 lb., 220; lb.. 40c; 2 lbs.. :0c. postpaid.

LIPROVED STRATAGEM, or POTLATCH. The best semi-dwarf main crop variety. Height 2 feet: rery robust: requires no support. Tery productive and pods borne in clusters near top of vine. Pods large and packed with immense peas of delicious sweetness. Pkt., 10c; $1 / 2$ lb. 25 c: lb. tom

CHAMPION OF ENGLAND. A late variety. Valuable to prolong the season. Very productive and universally admitted to be one of the richest and best flavored of the late Peas. Height 4 to 5 feet; Peas of large size and 6 to 9 in the pod. Plst., 10c; 1/2 1b., 22c; lb., 40c; 2 lbs., roc, postpaict.

QCITE CONTENT. The largest podded Pea in existence. The vines attain a height of $51 / 2$ to 6 feet and are practically covered with handsome pods that are gigantic in size. measuring 5 to 7 inches in length and containing 9 to 12 large, wrinkled peas of the finest table quality. Superb quality and great productiveness make this a most desirable main crop and late variety for both the marliet and the home garden. Pkt.. 10c: $1_{2}$ lb.. 25c; lb.. 45c: 2 lbs.. 80c, post iald.

DWARF GRAY SCGAR. Best edible-podded variety. Cook pods and all like snap beans. Pods much smaller than some of the other edible-podded sorts. but are of considerable better quality and very productive. Very early, being ready for use about the same time as little Marvel. Height 15 inches. Be sure to plant some of this variety, you will like them. Pkt., $10 \mathrm{c} ; 1 / 2$ lb., 25e; lb., 45e; 2 lbs., 86e, postpaid.

Inoculate Your Peas for Best Results Inoculation of seed hastens and enriches the soil. Garden size. sufficient for 5 pounds of seed and good for Peas, Sweet Peas, and Beans, 25c; Half Bushel Size (for Peas only), 65c; Bushel Size (Peas only), \$1.00. Inoculation good for Beans only at these same prices.

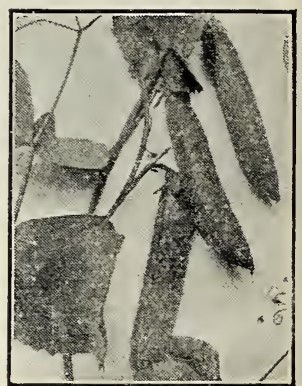

Laxtonian

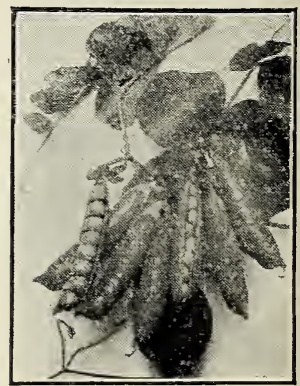

Hundredfold

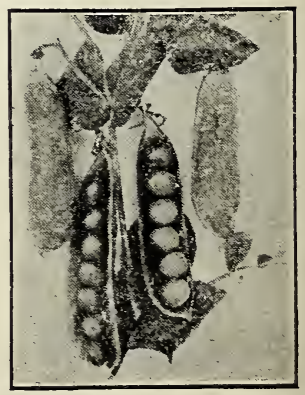

Little Marvel 


\section{Burgess' Peppers}

Many people have the mistaken itlea that it is difficult to grow Peppers, while in fact they are easily grown. Everyone with a garden should plant Peppers. They are excellent to have on hand for salads, pickles and mangues, and for seasoning meats and vegetable dishes.

One onnce of Pepper seed will produce 1,500 plants.

FARRIS' EMILIDST, The earliest and most prolific sweet Pepper producing ripe (red) Penpers the first part of August in the Northerl States, and plenty of green Peppers long before that date. Pepper: $3 \frac{1 / 2}{2}$ to 4 inches in lengil by $2 \frac{1}{2}$ to 3 inches in diameter and often a. unany as 20 on a single vlant, Very mild and sweet. Pkt., 10c; 3 pkts. 25c; oz., 60c; $1 / 4$ lb., \$1.80; 1b., \$6.00, postpaid.

HARRIS GARLY GIANT. The earliest large Pepper; only a few days later than Harris' Earliest, but much larger. The plants are very vig orous, growing $1 \frac{1}{2}$ to 2 feet ligh and actually loaded down with gian fruits. Thirty fruits will fill a $5 / 8$-bushel basket: thick ffoshrd. swent and pleasant flavor. Pkt., 10c; 3 pkts., 25c; oz., 15c; 1/4 lb., \$2.25; lb., $\$$ \%.50, postpaid.

CHINCSF GINT, Largest Pepper grown; magnificent appearance; flesh the thickest ever found in any of the large Peppers, superior flavor, very mild. Four to 5 inches broad and are of equal length. Plant. well branched and thickly set with enormous fruits. Only a few days later than Ruby King. Pkt., 10c; 3 pkts., 25c; oz., 75c; $1 / 4$ lb., \$2.25; lb., $\$$ \%.50, postpaid.

RUBY KYYG. The standard Sweet Pepper for home and market. Red Peppers about a month later than Harris' Earliest. Pkt., 8c; oz.

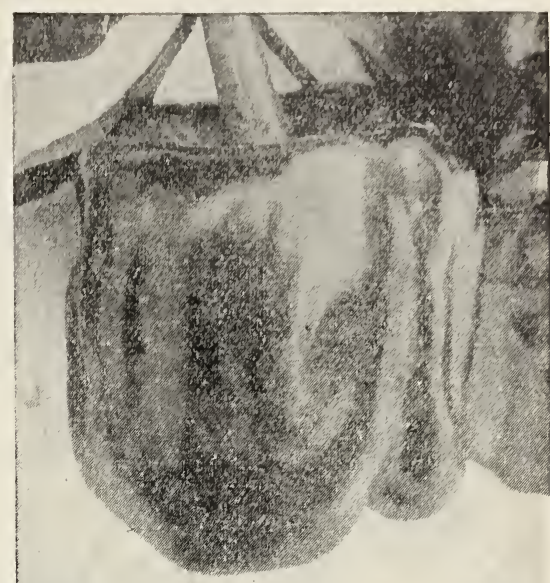

Chinese Giant Pepper

BULL NosE. Ripens crop uniformly and quite eariy. Fruits of medium size; bright scarlet; flesh thick; quite mild excepting in the cell partitions which are not entirely free from pungency. Popular for salads and pickling. Pkt., 8c; oz., 35̃c; 1/4 Ib., $\$ 1.00 ;$ lb., \$2.50. postpaid.

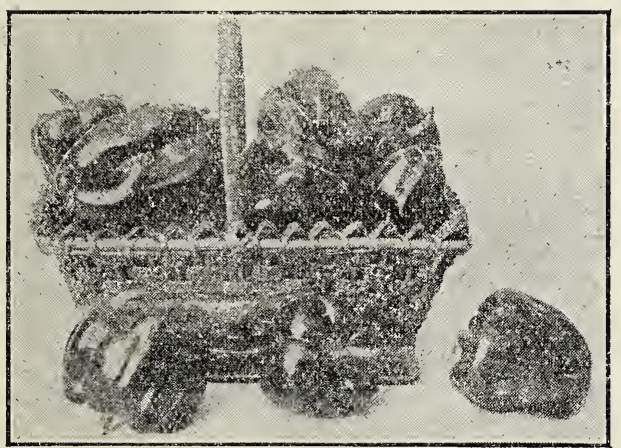

Harris' Earliest Pepper

SUNNYBROOK, or MMPROVED SWEET CHEESE. The outstand ing feature of this Pepper is its unusual fine flavor. The sweetest, and one of the most prolific of all Peppers; extremely early; flesh unusually thick. It is in great demand in all localities where it has been introduced. Plit., 10c; oz., 75̃c; 1/4 lb., \$2.25; lb., \$7.200, postpaid.

PIMENTO. The great thick-meated canning Pepper. Sweet as an apple. Only 8 or 10 days later than Ruby King. Pkt., 8c; oz. 3.sc; $1 / 4$ lb., \$1.00; lb., \$3.50, postpaid.

GOLDEY QUEFN. Largest, best and most handsome yellow Pepper: mild and sweet. Same season as Ruby King. Excellent home garden variety. Pkt., 10c; 3 pkts., 25e; oz., 45c; $1 / 4$ lb., \$1.50 lb., \$5.00, postpaid.

LONG RED CAIENNE. The leading hot Pepper. Pkt., 8c; oz. 40c; $1 / 4$ lb., \$1.25; lb., \$4.00, postpaid.

TIBASCO. Used exclusively for the famous Tabasco Sauce. Extremely hot. Pkt., 10c; oz., r0c; 1/4 lb., \$2.10; lb., \$7.00, postpaid.

BIRI'S EYE. Sold extensively by florists about Christmas time. Peppers are also edible; none better for pepper-sauce. The smallest ruited of all hot Peppers and also the most pungent in taste. Planted in garden in spring will supply an abundance of finest quality hot Peppers in fall, and plants can then be taken up and potted for house culture. Useful and ornamental. Fine for either vegetable or flower garden. Plst., 100; 3 pkts., 25c; oz., y5c, postpaid.

\section{Parsley}

One ounce to 160 feet of row.

CHAMPION MOSS CURLED. Finest and most handsome variety. Pkt., 5c; oz., 15c; $1 / 4$ lb., $40 \mathrm{c}:$ : $1 \mathrm{~b} ., \$ 1.25$, postpaid.

TURNIP ROOTED. The edible portion of this variety is the fleshy root, which resembles a smali parsnip. Excellent for flavoring soups, stervs, etc. Pkt., 8c, oz., 20c; $1 / 4$ lb., 60e; lb., $\$ 2.00$, postpaid.

\section{Pumpkin}

One ounce for 20 hills; 3 to 4 pounds per acre.

BIG TOM, or IMPROVED IARGE FIELD. Leading corn field Pumpkin. Smooth, hard, reddish-orange skin, with rich orange-yellow flesh. Wonderfully prolific. Pkt., 5e; oz., 12e; $1 / 4$ lb., 30c; lb., 85e, postpaid.

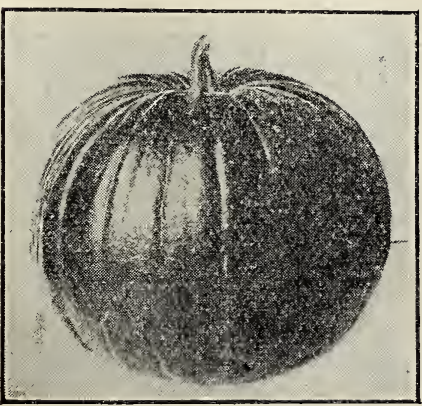

Snall Sugar Pumpkin
JUMO Often weigh 100 to 300 ibs. Always a prize winner at exhibitions. A good pie Pumpkin, splendid keeper, and valuable for feeding purposes. Pkt., 8c; oz., 15c; $1 / 4$ lb., 45̃c; lb., \$1.5̃o, postpaid.

FENTUCKY FIELO, or SWEET CHEESE. About 2 feet in diameter, round, flattened,

hard and productive. Fine for mariet and family use, and excellent for stock feed. Plst., 5c; oz., 10c; 1/4 lb., 25c; lb., 70c, postpaid.

SMALL SUGAR. The most popular pie pumplin. Looks like a Field Pumpkin, but is smaller and of much better quality. Flesh sweet and tender; the earliest Pumplin, matures in 65 days; excellent keeper. Plit., 5e; oz., 12c; 1/4 lb., 35c; lb., \$1.00, postpaid.

WIVTER LUXURY The best pie Pumpkin. Its winter-keeping quali1 ties are almost unequaled. Slightly oval in shape Flesh deep golden color, sweet and cooks quickly. A great producer. Pkt., 5c; oz., 15c; 1/4 lb., 40c; lb., \$1.25, postpaid. 


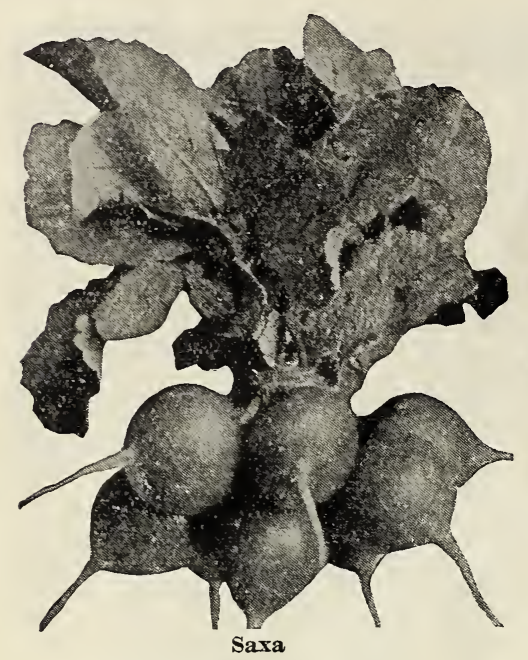

\section{SAXA RADISH}

\section{The Earliest Radish Grown}

We have found this new Radish to be earlier than any of the other so-called earliest sorts. 'The best extra tarly variety for forcing, and for growing in the open ground it has no superior. From the time of seed sowing to the table in 16 to 18 days, and under ideal conditions are fit to pull in 15 days. It is round, bright scarlet in color and has a very small top and taproot. Flesh pure white. crisp, brittle, mild and juicy. The Saxa is one of the slowest to shoot to seed. Pkt., 8c; oz., 15e; $1 / 4$ lb., 40c; lb., \$1.25, postpaid.

\section{Other Varieties of Radish \\ One ounce of seed for 100 feet of row.}

CRIMSON GIAYT. One of the finest Radishes grown. Suitable for forcing or euriy planting out of doors Largar than the other round red varieties. Roots free from hollow center or pithy fibre. Pkt., 5e; oz., 12e; $1 / 1 / 1$ lb., 30c; lb., 90c, postpaid.

EAKLY BIRD. Agresd upon by leading market growers as the most profitab.e variety. Because of quick maturity, rich scarlet color, perfect shape and superior quality, Early Bird gets customers and keeps them. In shape Early Bird is a slightly elongated globe; a!ways crisp, juicy and mild; fit to pull in 16 to 20 days. Pkt., 5c; oz., 12c; 1/4 lb., 35̃; $1 \mathrm{~b}$. si.0n. nostpaid.

EARIY SCARLET TURNIP. Early round red Radish; later than Saxa. Very desirable for early outdoor planting. Pkt., 5c; oz., 12c; 1/4 lb., 30c; lb., \&.se, postpaid.

EARLY WHITE TCRNIP. The earliest white Racish; always mild and crisp. Pkt., 5e; oz., 12e; $1 / 4$ lb. 30c; lb. 85e, postpaic.

EARLY LONG SCARLET SHORT TOP. The best long red Radish. Pkt., 5c; oz., 10c; 1/4 lb., 25c; lb.,

Foc, postpaid. FRENCH BREATFAsT.
Pkt., 5c; oz., 12c; $1 / 4$ lb., 30c: 1 b., sac, postpaid.

ICICLE. The best long white Radish; mild and sweet. A favorite with market gardeners and for the home garden. Pkt.. 5e; oz., 10e; 1/4 lb.. 25e; lb., 75e, postpaid.

WHITE TIPPED SCARLET TCRNIP. A favorite in all markets, owing to its fine appearance. Handsome bright scarlet color with white tip. One of the best early varietics for outdoor sowing; excellent quality. Pkt., 5c; oz., 12c; $1 / 4$ lb., 30c; lb., 85c, postpaid.

LONG WHITE STRASSBURG. The best summer Radish, withstanding hot weather the best of any sort. Pure white; firm and brittle. Pkt., 5c; oz., 12c; $1 / 4$ lb., 35c; lb., \$1.00, postpaid.

LONG BLACK SPAXISH. Keeps best and longest of all winter Radishes. Skin coal-black; flesh white and crisp; excellent quality. Pkt., 5c; oz., 12c; 1/4 lb., 35c; lb., \$1.00, postpaid.

SCARLET CHINA. A favorite winter Radish. Very handsome; of medium size; rose color; flesh white. By packing in sand, fresh, crisp radishes may be had all winter. Pkt., 5c; oz., 12c; 1/4 lb., 35c; 1b., \$1.00, postpaid. PRIZE MIXTURE. All the leading early varieties mixed. Pkt., 5e; oz., 10c; 1/4 lb., 25e; lb., i5e, postpaid.

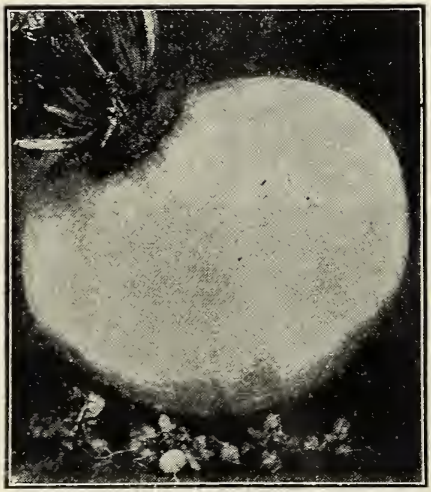

Photograph of Sakurijima and common Scarlet Turnip Radishes, to show the comparative size.

\section{JAPANESE GIANT RADISHES}

The Japanese Radish. or Dailion, as it is known in Japan, is the leading vegetable of Japan, being used as extensively there as the potato is here in America. It is not only eaten raw, but is cooked like Turnips. The Japanese Radishes are of excellent quality and always attract considerable attention on account of their monstrous size.

NERIMA LONG. An exceedingly sweet-flavored, long white radish. Grows 3 feet long; very crisp and brittle. Fine for all styles of couking and excellent for pickles. One of the best for eating raw. Pkt., 10c; 3 pkts., 20c; oz., 35c, postpaid.

SAKURIJLMA, or Poultry Radish. The largest variety of radish in cultivation. Often attains a weight of $15 \mathrm{lbs}$, and some grow to more than $30 \mathrm{lbs}$. Nearly round. A great curiosity and a radish of extraordinary quality. Flesh solid, firm and brittle, A great curstexcllent flavor. A favorite for fall and winter use, and a valuable winter feed for cattle and poultry. Every poultryman should plant some of them. Pkt., 10c; oz., 30c; $1 / 4$ lb., 90c; 1h., \$3.00, pnst pr?

\section{$191 / 2 \mathrm{lb}$. Radish from Burgess' Seeds}

On February 14, 1928, Mr. Ted Huxford, Marysville, Iowa, wrote us as follows: "Last year I bought a package of Sakurijima Radish seed from you. The largest of the radishes attained the weight of $19 \frac{1 / 2}{2}$ lbs. I am a booster for Burgess Co. Enclosed is my 1928 order."

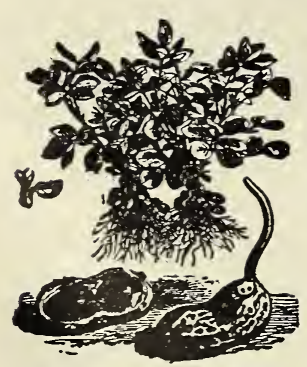

\section{NORTHERN GROWN PEANUTS}

Just as good Peanuts can be grown in the Northern States as in the South, provided you plant Improved Early Spanish. This is the earliest variety grown, and very productive. The pods are small, but remarkably solid and well filled with nuts of the very finest quality. Shell nuts carefully so as not to break inside skin, and plant as soon as ground becomes warm, about 2 inches deep, in rows 3 feet apart, and from 8 to 10 inches apart in the row. Pkt., 10c; pt., 25c; qt., 40c; 3 qts., \$1.10; 6 qts., \$2.00, postpaid.

\section{PARSNIPS}

One ounce to 150 feet of row; 4 to 6 pounds per acre.

MIPROVED HOLLOW CROWN. The best variety. Pkt., 5c; oz., Improved Early Spanish 12c; $1 / 4$ lb., 35c; lb., \$1.00, postpaid.

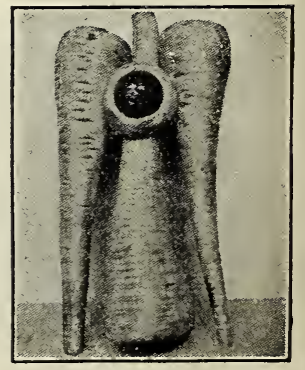

I. H. C. Parsnip 


\section{Squash}

Summer Squash-One ounce to 25 hills; 3 to 4 lbs. per acre.

Winter squash-One ounce to 10 hills; 3 to 4 lbs. per acre.

DELICIOL. Lnsurpassed for sweetness, richness of flavor and extraordinary quality. Excellent for fall and winter use; keeps well traordinary qually weigh 5 to 10 lbs.; rind dark until late in the spring. Frults usually weigh 5 to 10 los., rind dick and green, mottled in lighter shades; dark orange flesh, very thick a
fine grained. Plst., 10c; oz., 20c; 1/4 lb., 55e; lb., \$1.75, postpaid.

TRIE H(BIBAR). The old stand-by, and most popular winter variety. Plt.. Sc; oz., 15c: 1/4 lb., 45c; lb., \$1.50, postpaid.

BLUE IIUBA RI). A large Squash of the Hubbard shape; color blue-gray; extra thick nieated; excellent quality. Pkt., 8c; oz., 15̄c; 3/4 lb., $45 \mathrm{c} ; 1 \mathrm{~b} . . \leqslant 1 . .00$, postpaid.

CHICAGo WilT HUIBARD. Preferred by many to True Hubbard. Popular with market growers catering to a fancy trade. Pkt. 8c: 15c: 1/4 lb., 45c; lb.. \$1.50, postpaid.

GOLDEN OR RED IICBBARI. A week earlier than True Hubbard, and of the same shape and quality. Plit., 8c; oz., 15c; 1/4 1b., $45 \mathrm{c} ; 1 \mathrm{~b} .$. \$1.50. postpaid.

TABLE QUFEN. A popular variety for baking: 6 to 7 inches long

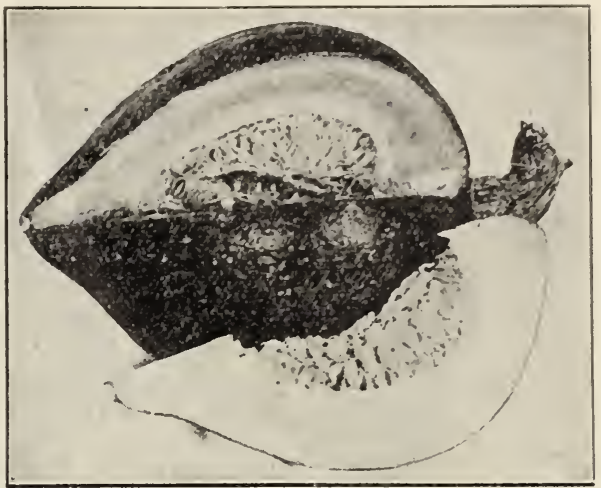

Delicious squash The meat is exceptionally dry and of extra fine flavor. The shell is thin, but hard and smooth, and they keep as $\pi$ ell as the Hubbard. Pl., 10c; oz., 20c; $1 / 4$ lb, 55e; $1 \mathrm{l}$, \$1. 75 , postpaid.

GIAT STMUEK CROOKNECK. The most popular Summer Squash; one of the earliest

1b.. 40c: 1 b., \$1.25. postpaid.

EARLY WHITE BCSH. Our special strain of this variety is the earliest Squash grown. Very productive; a favorite Summer Squash with market gardeners. Pkt., 8c; oz., 15c; 1/4 lb., 45c; lb., \$1.40, postpaid.

MAMUOTH WHITE BCSH SCALLOP. Larger than Early White Bush and a few days later. Pkt., 8c; oz., 15̃c; 1/4 1b., $40 \mathrm{c} ; 1 \mathrm{~b} . . . \$ 1.25$, postpaid.

COCOZFLLE. or ITALIAN MARROW. One of the most delicious additions to the Squash family. For piquancy of flavor, tenderness and general palatability it has few equals. This plant does not make a vine, but grows in the form

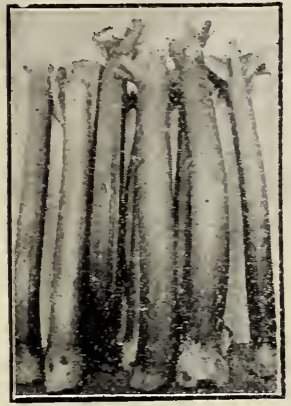

Early Giant Rhubarb

should be picked when not more than 4 to 6 inches long. If the fruits are allowed to larger they lose their delicacy of flavor, and when one fruit is allowed to mature it checks the formation of any more fruit on the plant. The fruits form and grow rapidly and may be picked almost every day until frost. If planted early it will fruit from the latter part of June until October. Can be cooked like Asparagus or Squash, and most excellent when prepared like French fried potatoes. Pkt., 8c; oz., 15̃c; 1/4 1b., 45̌c; lb., \$1.50, postpaid.

\section{Early Giant Rhubarb}

One ounce to 100 feet of row.

EARLY GIANT is mammoth in size, and the best and earliest variety. It is the first vegetable from the ground in the spring and the easiest of all perennial plants to grow. A half dozen plants will supply a large family during the season, and plants well established will last for years. We cffer a fine stock of roots this season. $25 \mathrm{c}$ each; 3 for $50 \mathrm{c} ; 6$ for $\mathbf{8 5 c ;} 12$ for $\$ 1.50$, by parcel post, prepaid. By express, not prepaid, \$4.00 per 50 or \$7.50 per 100 .

We aiways recommend the planting of Rhubarb roots instead of seed, but if seed is wanted, we can supply seed of the genuine Early Giant at 10c per packet; 25c per oz.; $70 \mathrm{c}$ per 1/4 1b.; or $\$ 2.25$ per lb., postpaid.

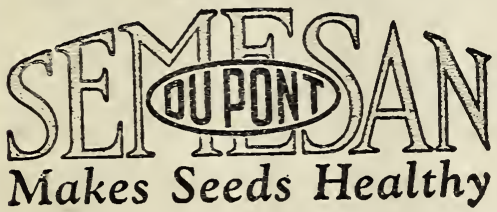

seed borne fungore is no need to 列 gam weather conditions ease-free start. Help them resing . This remarkable seed and crops to mature earlier, and produces larger yields of finer crops. One pound of SEMESAN will treat 240 pounds of the average seed by the dust method or 960 pounds if liquid applications are employed, at a cost of from only one-fourth to one cent per pound of seed. SEMESAN is easily applied, harmless to seed and plant life but deadly to the diseases that rob you.

SEMESAN is recommended by Government experts, agricultura colleges, county agents and large growers in every section of the country. You should be using this moderate-priced, effective crop protection.

Notice in the illustration the difference in yield of untreated and treated seed potatoes. The difference in other crops is equally as great.

SEMES 2 (For Seeds, Plants, Bulbs and Potatoes). 2-oz., 50c; $1-1 b . . \$ 2.75 ; 5-1 b ., \$ 13.00 ; 25-1 b ., \$ 56.25$, by express, not prepaid.

SEMESAN BEL (An Instantaneous Dip Disinfectant for Seed Potatoes). 1-1b., \$1.75; 5-1b., \$8.00; 25-1b., \$31.25, by express, not prepaid.

SPECIAL NOTICE. SEMESAN BEL is used especially for the seed disinfection of white and sweet potatoes. It is not recommended for the treatment of the common farm, flower and vegetable seeds as SEMESAN is more suited for these purposes. SEMESAN can be used on all kinds of seeds, plants and bulbs, including potatoes, but SEMESAN. BEL is just as good for potatoes and costs less. Postal regulations prohibit the mailing of poisons, so SEMESAN and SEMESAN BEL must be sent by express.

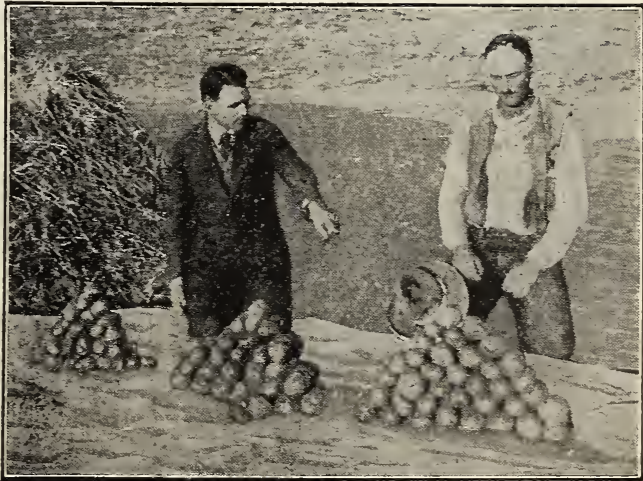

Comparatice Yields Prove Semesan's Value

The left-hand pile in the above illustration represents the yield from three average hills of untreated seed potatoes; the center pile from three hills treated with formaldehyde; and the right from three hills of SEMESAN disinfected seeds. This test was conducted. at Ellensburg, Washington, by Leslie Wilson and E. E. Mundy. 


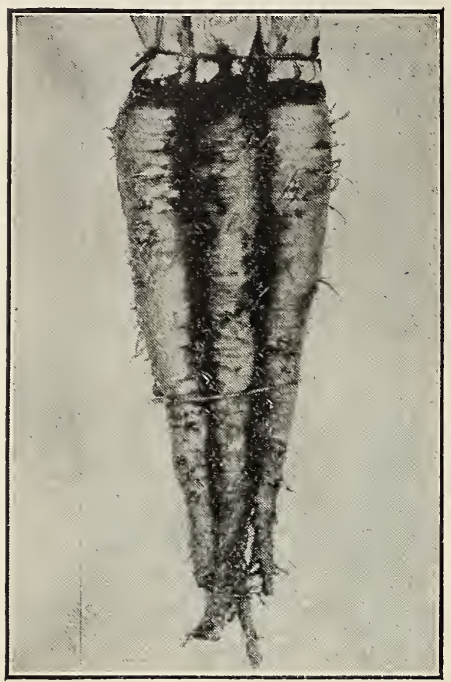

Salsify

\section{Spinach}

One ounce to 100 feet of row.

BLOOMSDALE. Leaves are curled and wrinkled; very early, blight-resistant, and hardy; extensively planted for market and canning. Pkt., 5c; oz., 10c; $1 / 4 \mathrm{lb}$., 20c; lb., 50c, postpaid.

KLNG OF DENMARK. A valuable new variety. Leaves are large, crumpled, deep green; very early, yet remaining in good condition a week or two after other kinds have run to seed. Pkt., 5c; oz., 10c; $1 / 4$ lb., 20c; lb., 60c, postpaid.

MONSTROUS VIROFLAY, or THICKLEAF. A variety bearing thick leaves measuring up to 10 inches in length and 8 inches wide. Plants measure 24 to 30 inches across on highly fertilized land. Grows more rapidly than other kinds, so can be used earlier. Pkt., 5c; oz., 10c; $1 / 4$ lb., 20c; lb., 50c, postpaid.

VICTORIA. A large-growing variety which is noted for its dark green leaves and ability to withstand hot weather. Leaves are only slightly crumpled, and of finest quality. It is a heavy yielder, and unexcelled for spring or fall sowing. Pkt., 5c; oz., 10c; $1 / 4$ lb., 20c; lb., 50c, postpaid.

NEW ZEALAND or EVERBEARING. A distinct type of Spinach with small green leaves, which makes large, bushy plants, often 3 feet in diameter. Only the young leaves and tips of the branches are used, and the more they are picked the faster the plant seems to grow. It will give you fine greens all summer and fall. Especially suited to dry and arid locations where other varieties do not do well, and the only kinc that can be successfully grown in extremely hot weather. Plit., 5c: oz., 12c; $1 / 4$ lb., 35c: lb., \$1.00, postpaid.

\section{Salsify or Vegetable Oyster}

One ounce to 75 feet of row.

MAMMOTH SANDWICH ISLAND. The best variety. Pkt., 10c; oz., 25e; $1 / 4$ lb., \%0e; lb., \$2.25, postpaid.

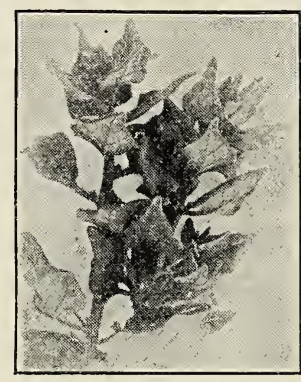

New Zealand Spinacb

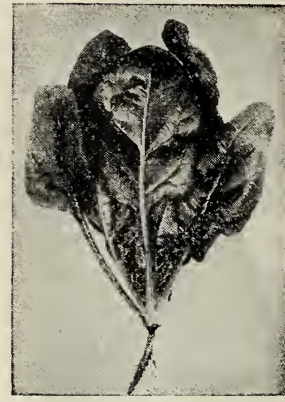

Victoria Spinach

\section{SEE MARKET GROWERS' WHOLESALE PRICES ON PAGES 76, 77, AND 78}

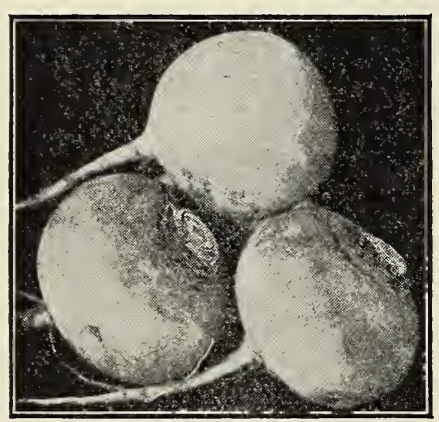

Purple Top White Globe

\section{Turnips}

One ounce to 100 feet of row; $11 \frac{1}{2}$ to $3 \mathrm{lbs}$. per acre.

AMBER GLOBE. The best large yellow late sort. Skin light yellow; flesh yellow, firm and sweet. Fine for table use and stock feeding. A good cropper and keeps in perfect condition until spring. Pkt., 5c; oz., 10c; $1 / 4$ lb., 25c; lb., 75c, postpaid.

ORANGE JELLY, OR GOLDEN BALL. The best early yellow Turnip. Not of large size, but firm and of excellent flavor. Keeps well. Pkt., 5c; oz., 10c; 1/4 lb., 25c; lb., 75c, postpaid.

EXTRA EARLY PURPLE TOP MILAN. The earliest Turnip grown. The bulb is flat, of medium size; white, with a bright purple top; and in quality the best. Planted extensively for first market crop, but not as $w$ ll suited for summer planting. Reaches marketable size in 50 days. Pkt., 5c; oz., 15̌; 1/4 lb., 35c; lb., $\$ 1.00$, postpaid.

EARLY PURPLE TOP STRAP LEAF. The standard early variety, Roots broad and fat, of medium size; white, purple top. Extensively sown for both table use and stock feeding. Pkt., 5c; oz., 10c; $1 / 4$ lb., 25c; lb., 75c, postpaid.

PURPLE TOP WHITE GLOBE. The most popular white Turnip for fall and winter use. Flesh pure white, fine rained and of fine flavor. Heavy yielder and splendid keeper. Desirable for table or stock. Pkt., 5c; oz., 10c; $1 / 4$ lb., $25 \mathrm{c}$; lb., 75c, postpaid.

WHITE EGG. A quick growing, egg-shaped, smooth, pure white variety. Flesh firm, sweet and mild. Adapted to either spring or fall sowing. Pkt., 5c; oz., 10c; $1 / 4$ lb., 25c; lb., ז̃c, postpaid.

COTV HORY 12 to 15 inches long by 3 inches across; white, green top; grow partly above the ground; sweet and of fine flavor. Very valuable as a soil enricher. Can be sown broadcast on stubble ground, will grow on poor, worn-out soils, and if plowed under will enrich it as much as a crop of clover. Pkt., 5c; oz., 10c; $1 / 4 \mathrm{lb}$., 25c; lb., 75c, postpaid.

\section{Japanese Mammoth Turnip}

SHOGOIV quently grow to more than 15 pounds. Round, pure white, very solid and sweet. The best keeper, a good table variety, and an excellent feed for cattle. Pkt., 10c; oz., 30c; 1/4 lb., 90c; lb., $\$ 3.00$ postpaid.

\section{Rutabagas, or Swedes}

Rutabagas require a sown earlier, or about the middle of June.

One ounce for 200 feet of row; 1 to $11 / 2$ lbs. per acre.

IMPROVED PURPLE TOP YELLOW. The best yellow variety; fine flavor. Pkt., 5c; oz., 10c; $1 / 4$ lb., 25c; lb., 75c, postpaid.

MONARCH OR ELEPHANT Mammoth yellow variety; yields enormous crops. Grown principally for stock feeding, but is good for table use. Pkt., 5c; oz., 10c: 1/4 lb., 25c; lb., 75c, postpaid.

SWEET RUSSIA. Excellent keeper; flesh white, very firm and sweet. Plkt., 5c; oz., 10c; 1/4 lb., 25c; lb., 75c, postpaid.

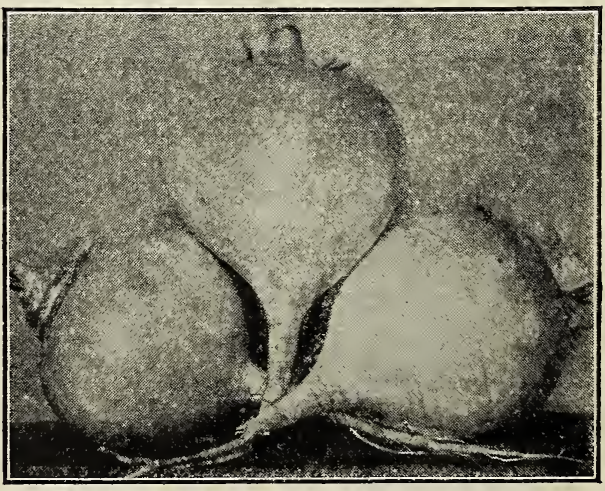

Improved Purple Top Yellow Rutabaga 


\section{TOMATOES}

Every season sees a big increase in the demand for our Michigan grown Tomato seed. Climatic conditions in Michigan are conducive to freedom froll disease, to the production of fruit instead of vine and to early maturity. Our strasns ketp these tendencies to a marked degree when planted eisewhere A trial will convince you of the superiority of ou One ounce of seed will produce about 2,000 plants. BIRGES, FIRIIEST ANI) HEST. Probably the most valuable Tomato grown. See inside front cover of this catalog for description. Pkt., 10c; oz., 50c; 1/. 1b., \$1.50; 1b., \$5.00, postpaid.

BEEFSTEAK Nearly as large as Ponderosa: iut into thick ruby slices of meaty fruits which will quality. Many of our customers who have tried it report it to be the most delicious Tomato they have ever eaten. Pht., 10c; oz., 60c; 1/4 lb., \$1.80; lb., $\$ 6.00$, postpaid.

BONXY BEST. A favorite bright scarlet early variety, maturing a little later than Earliana. Pkt., $8 \mathrm{c}$; oz., 35c; 1/4 1b., \$1.00; 1b., \$3.50, postpaid.

CHALF'S EARIY JFITEL. Large, scarlet, smooth fruits; considered by many to be the best second-early sort. Pht., 8c; oz., 35 c; $1 / 4$ lb., $\$ 1.00$; lb., $\$ 3.50$, postpaid.

COOPER'S SPECIAL. An improred strain of Livingston's Globe. Fruits purple; globe shaped. It yields heavier than Globe and its carrying qualities are equally as good. A most wonderful variety for the Southern planter. Matures earlier than most main crop sorts and keeps on bearing almost until b.. \$1.50; 1b., \$5.00, postpaid.

\section{COLOSSAL, the Largest Tomato Grown \\ COLOSSAL, the Largest Tomato Grown} Ponderosa. Many planters, in distrent parts of the country have grown Colossal Tomatoes weighing orer 3 lbs., and some more than 4 lbs. Not only does the Colossal produce giant fruits. but it produces them in abun-
dance. One planter in Illinois raised over a ton of Tomatoes from 186 dance. One planter in Illinois raised over a ton of Tomatoes from 186
plants. The very thick. meaty flesh. few seeds, and mild flavor combine to gire the Colossal a quality on a par with its immense size. Unsurpassed for slicing or canning. Pkt., 20c; 3 pkts., 50c; oz., \$1.00, postpaid.

Yellow Colossal The largest yellow Tomato: just like Colossal low. Pht., 20c; 3 phts., 50c; oz., $\$ 1.00$, postpaid.

DWARF STONE. The best of the dwarf growing sorts. The fruits. which hang well up off the ground, are nearly as large as those of the Original Stone, and excellent in quality. smooth, meaty and solid. Dwarf varieties do not produce as many fruits to the plant as the larger sorts, but owing to their small size and upright growth twice as many plants can be set in $1 / 4$ lb., $\$ 1.40 ; 1 \mathrm{~b} ., \$ 4.50$, postpaid.

EARLIANA. The most popular extra-early Tomato. Fields well: fruit bright red. solid and of fine quality. Our strain of this variety is extremely early and is much superior to seed produced farther South. Pkt., $8 \mathrm{e}$; oz., $35 \mathrm{c}$; $1 / 4 \mathrm{tb}$., $\$ 1.00$; b., \$3.50, postpaid.

GOLDEX QUEEX. The leading yellow Tomato. Many consider it of better flavor than any of the red varieties, and is less acid. Pkt., 10c; oz., 45c; 1/4 1b., \$1.40; 1b., \$4.50, postpaid.

JCNE PINK. The earliest pink variety. Only 2 or 3 dass later than Earliana, but larger, and of better quality. Pht., 10c; oz., 50c; 1 if lb., \$1.50; 1b., \$5.00, postpaid.

LIVIGSTON's GLOBE. One of the most popular main crop rarieties. The leading variety in the South for shipping to Northern markets. Pkt., 10c; oz., 50c; 1/4 lb., \$1.50; lb., \$5.00, postpaid.

MAROLOBE A wonderful new variety which is resistant to nail-head rust and fusarium wilt. Pipens 10 to 12 dass later than Earliana: large, perfect globe-shaped fruits of a beautiful scarlet color. Its IORTON WILT-RESISTANT. If you are bothered with wilt in rour locality, you will be interested in this variety. The Norton resembles the Stone in appearance and bearing season. Fruits vert nirm, solid, smooth and of very fine flavor. An excellent variety for canning. Pkt., 10c; oz., 45c; 1/4 lb., \$1.40; 1b., \$1.50, postpaid.

PONDEROSA. With the exception of Colossal. this variety is the largest Tomato grown; very few seeds; excellent quality. Plat., 10c; oz., 60c; 1/ 1b., \$1.80; lb., \$6.00, postpaid.

STONE. The old stand-by. Large, bright red, perfectly smooth, main crop Tomato. Plt, 8c; oz., 30c; 1/4 1b., 90c;

ib., $\$ 3.00$, postpaid.

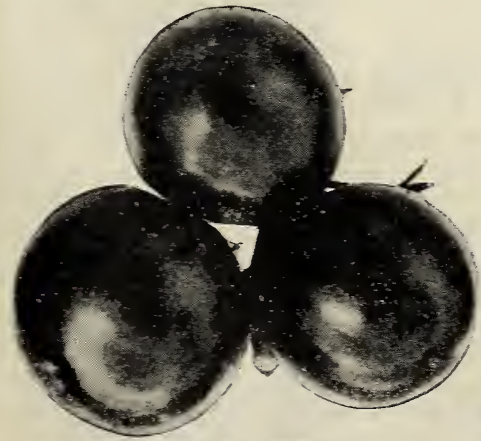

Marglobe Tomato

White Beauty Irory-white in color and the flesh is almost paper white. quality: contains absolutely no acid, so can be eaten by thousands of people who have heretofore aroided Tomatoes on account of the acidity. Pkt., 15c; 2 plts., 25c; 5 pkts., 50c, postpaid.

\section{Small Fruited and Preserving Tomatoes}

The following miniature Tomatoes are named for various fruits and are tery ornamental. as well as delicious in salads, preserves and pickles: Red Cherry. Red Pear, Red Plum. Yellow Cherry, Yellow Pear, Yellow Plum. 10c per pkt.; 50c per oz.; 6 pkts., one of each, for $35 \bar{c}$.

SMALC FRTITED IN MIXTCRE. All kinds of small fruited preserving varieties mixed; all shapes and colors. Interesting and useful. Plant a few for the children. Pkt., 10c; 3 phts., 25c; oz., 50c, postpaid. 


\section{Make Money} Growing Medical Plants

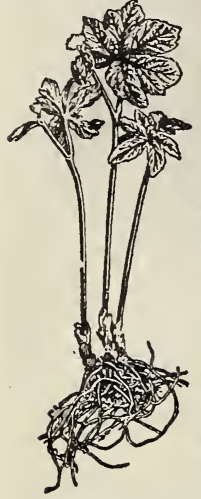

Golden Seal

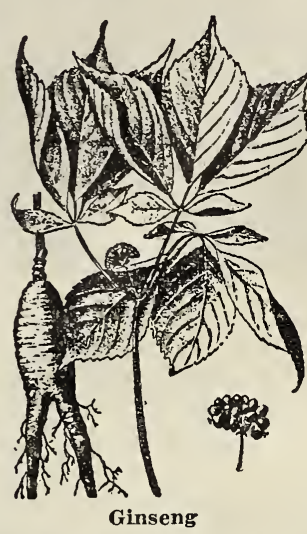

Drugs have greatly increased in prices cluring the past few years, so now the time to commence growing root crons for medical purposes. Golden Seal and Ginseng are the two biggest money makers. The roots sell at enormous prices, and there is no reason why the prices will not steadily increase year after year. These plants formerly grew wild in most of the Northern States, and in many parts of the South. and it was from these wild plants that the supply of roots was formerly secured. The crop of wild roots is now nearly exhausted, and it has become necessary to cultivate these plants. The demand is increasing each year, and the supply decreasing. so you will be making no mistake in devoting a part of your time to the growing of these two plants.

COLDEN SEAL Golden Seal is easily grown, and when ready G.LLID to dig, the roots should average at least one nince each. green. This would make 18 pounds of dry roots to each square the rate an acre would be worth $\$ 8,640.00$. Besides this, enough small plants will be found to set out twice as large a patch and the fibrous roots that are left in the ground will form buds and reset the patch.

The figures we give are not overdrawn. A leading buyer of medicinal roots says he bought a cron of cultivated Golden Seal that averaged nearly 8 ounces per root, dried. They were worth about $\$ 2.25$ each. Think of it! An acre of such Golien Seal would bring $\$ 316.800 .00$ Any good, well drained soil is suitable for the growing of Golden Seal. Seed should be planted in the fall, but as our supply is limited, you should order right away. Send cash with order, and seeds will be mailed to you at the proper time for planting. Sold in sealed packets only. With each order for seed we will send complete cultural directinns and the names and addresses of medical root buyers who will bily the roots from you. 36 packages of seerl will plant one square rod. Pkt., 25e; 5 pkts., \$1.00; 12 pkts., \$2.00; 36 pkts., \$5.00; 80 pkts., \$10.00; 250 pkts., \$25.00, postpaid.

GJNGT Ginseng is another money maker. Read the following news item, clipped from a Wisconsin daily G paper:

"Wausau Wis. May 21-(Special)-Perhaps by far the most valuable load of products of the soil that ever crosser the streets of Wausau, was seen a few days ago, drawn by one horse. The load consisted of eighteen inconspicuous barrels and no one would have surmised its value had it not been that J. H. Koehler was seen watching it with eagle eyes. Upon inquiry it was found that the barrels contained $1.3431 / 2$ pounds of ginseng, which had been sold for $\$ 8,061.00$, and was now being started on its long journey to China. The crop was grown on one-half acre of ground near Wausau." The average market price of dry Ginseng ronts is generally about $\$ 7.00$ or $\$ 8.00$ per pound, but at the time of going to press with this catalog, buyers are paying $\$ 12.00$ per pound for roots of the best quality, and there seems little likelihood of any radical slump in price.

Ginseng should be planted in the fall, but to be certain of getting the seed, you should order same as soon as possible, for we will probably have our supply all sold long before planting time. The best way is to order your Ginseng seed at the same time you order your other seeds: then we can be sure to supply you. With each order for seed we will send complete cultural directions and names and ad dresses of buyers who will buy the roots from you. Pkt., 25c; 5 pkts., \$1.00; 12 pkts., \$2.00; 36 pkts., \$5.00; 80 pkts., \$10.00; 250 pkts., \$25.00, postpaid.

\section{Golden Seal and Ginseng Plants}

We have but a limited number of the plants to offer. Place your order as early as possible, and plants will be sent at the proper time for transplanting. in the fall only, depending upon the season. P'an on setting about 800 plants to each square rod.

Prices of either Golden Seal or Ginseng Plantc: One nlant, 25e; 6 for $750 ; 12$ for $\$ 1.25 ; 25$ for $\$ 2.00 ; 50$ for $\$ 3.50$; 100 for $\$ 6.00 ; 250$ for $\$ 13.50 ; 500$ for $\$ 25.00: 1.000$ for $\$ 45.00 ;$ delivercd to any part of the United States, prenaid.

\section{HERBS}

They take up so little room. and as they are almost in dispensable for savory cooking, a few should be planted in every garden. If they are to be used during the winter. the stalks should be cut on a dry day. when not quite in full bloom, and dried quickly in the shade. When dry ties marked with an asterisk (*) are perennial.

ANisE. Used for garnishing, seasoning and for cordials. Pkt., 8c; oz., 25e.

BASIL, Sweet. Leaves used for flavoring soups, stew's and highly seasoned dishes. Pkt., 8c; oz.. 2.̃c.

BORAGE. Young leaves used as salad and flavoring: grown for bee pasture. Pkt., 8c; oz., 20c: $1 / 4$ lb., 60c.

*CARAWAY. Seeds used for flavoring pastry, meats, etc. Pkt., 8c; oz., 15e; $1 / 4$ lb.. $40 c$.

*CATNIP, or CATMINT. Leaves and young shoots used for seasoning. Tea made from the dried leaves is good for colds and indigestion. Grown for the bee pasture and for cats. Said to be a "cure-all" for cat diseases. Pkt., 10e; 3 pkts., 25e; oz., 65e.

CORIANDER. Seed used in confectionery and culinary preparations. Pkt., 8c; oz., 15c.

DDL. Leaves used for flavoring pickles, soups and sauces. Pkt., 8c; oz., 12c; $1 / 4$ lb., 35c; lb., \$1.00.

* FENNEL, Sweet. The leaves, boiled. are used for fish sauces, and are beautiful for garnishing. The seeds are used for flavoring. Pkt., 8c; oz., 20e.

*HOREHOUND. Used for flavoring candy and in the manufacturing of cough medicine. Horehound tea is a remedy for colds and lung affections. Pkt., 10c; oz., 40c. *HYSSOP. The flower summits and leaves are used as a remedy for asthma and catarrh. A stimulant, expectorant and mild tonic. Pkt., 8c; oz., 25c.

MARJORAM, Sweet. Leaves and ends of the shoots used for flavoring in summer, and also dried for winter use. Pkt., 8c; 3 pkts., 20c; oz., 40c.
*LAVENDER. The leaves are sometimes used for seasoning, but the plant is chiefly grown for its flowers, which are used in the making of perfumes. The dried flowers and leaves are fine for porfuming dresser drawers and linen closets, filling soft cushions, etc. Pkt., 10c; oz., 35c.

*ROSEMARY. Leaves used for seasoning. The oil is valuable in neuralgia, rheumatism and lumbago: Pkt. 10c; 3 pkts., 25e; oz., 60c.

*SAGE. Leaves and tops used for seasoning and dressing. Plit., 10c; 3 pkts., 25c; oz., 40c; $1 / 4$ lb., \$1.25.

STMLER SAVORY. Leaves and young shoots used for flavoring; especially string beans. Pkt., 8c; oz., 25c.

*THYyIE. Leaves and young shoots used for seasoning. tea is also made from the leaves and used as a remedy for headache. Pkt., 10c; 3 pkts., 25c; oz., 60c.

*WORMTWOD. Leav's us d as a tonic and as a dressing or fresh bruises. Also benenicial tor poultry. Pht., 10c; oz., 30c.

\section{TOBACCO}

One ounce will produce about 5,000 plants.

Grow your own Tobacco and have a good supply of pure, unadulterated natural leaf that has not been "doped" or "doctored" up by the manufacturer. A packet or two of seed will grow enough to supply most anyone.

CONNECTICUT SEED LEAF. The leading variety in the Northern and Middle States. Can be successfully grown even in the far North. Pkt., 10c; oz., 45c; $1 / 4 \mathrm{lb}$. $\$ 1.50 ;$ lb., \$5.00, postpaid.

FINE HAVAXA. Choice seed from an extra select strain; large leaf; one of the earliest. Pkt., 10c; oz., 45c; $1 / 4$ lb., \$1.50; lb., \$5.00, postpaid.

MIPROVED WHITE BURLEY. Extra select strain. Popular variety for chewing. Pkt., 10c; oz., 45c; $1 / 4$ lb. $\$ 1 . \tilde{0}$; lb., $\$ \tilde{5.00}$, postpaid. 


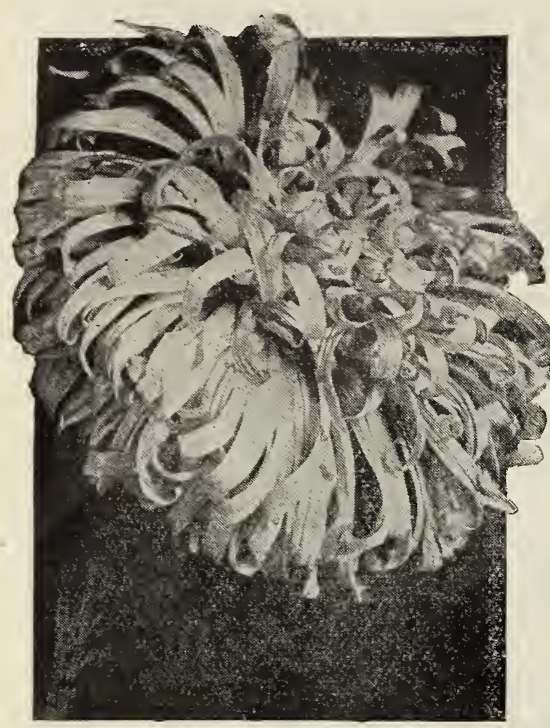

Giant Ostrich Feather Aster

\section{Giant Ostrich Feather Asters}

We are now offering our improved strain of Giant Ostrich Feather and consider it the finest of all Asters. The plants are about $21 / 2$ feet high, robust in growth and branch freely and are loaded with magnificent feathery, full, fluffy flowers of large size. Borne on long stems, they make cut flowers par excellence. We offer the following colors: Crimson, Brilliant Rose, Pink, Light Blue, Dark Blue, Pure White, White Changing to Sky Blue, Pale Yellow. Separate colors or mixed. 10e per packet; 3 pkts., 25c; 8 plsts., 60c.

\section{Queen of the Market Asters}

Our early strain of Queen of the Market Asters is a most valuable type for bedding as well as cutting, as they are the first to come into bloom, and continue blooming until checked by fall frosts. Plants are 15 to 18 inches in height and branch freely near the ground, giving long stems to the flowers. We can supply the seed in the following colors: White, Pink, Crimson, Light Blue, Dark Blue, Scar'et. Separate colors or mixed. 10e per packet; 3 pkts., 25e; 6 pkts., 45̃c.

\section{King Asters}

In form the flower is entirely distinct from any other variety. The blossoms are round, full, and very large; long, narrow, quilled petals, those in the center being curled and incurved, completely covering the crown. Crimson, Pink, Rose, Lavender, Violet, White. Separate colors or mixed, 10c per packet; 3 pkts., 25c; 6 pkts., 45 c.

\section{Giant Chrysanthemum-Flowered Comet Asters}

Our select strain of the Chrysanthemum-Flowered Comet Aster is larger and finer than the much advertised Astermum. Flowers 4 to 6 inches in diameter, very double; long, curled, twisted petals, resembling fine Japanese Chrysanthemums. Rose, Crimson, Sulphur-Yellow, Light Blue, Dark Blue, White. Separate colors or mixed, 10c per packet; 3 pkts., 25e; 6 pkts., 45e.

\section{American or Late Branching Asters}

A grand strain of American origin. Plants form strong, branching bushes 2 to $2 \frac{1}{2}$ feet in height, bearing on long, strong stems, flowers which are very double and, under ordinary cultivation, average 5 inches across. Crimson, Scarlet, Bright Rose, Peach Blossom, Flesh, Sky Blue, Purple, Light Yellow, White. Separate colors or mixed, 10e per packet; 3 plits 25e; 9 pkts., 65e.

\section{Triumph of Paris Aster}

A beautiful white Aster with large quilled yeliow center. Pkt., 10c; 3 pkts., 25c. PEONY-FLOWERED PERFECTION ASTERS. Very large and double. A choice mixture of all colors. Pkt., 10e; 3 pkts., 25e.

YELLOW ASTERS yellow Asters ever offered. Pkt., 15̃c; 2 plits., 25c.

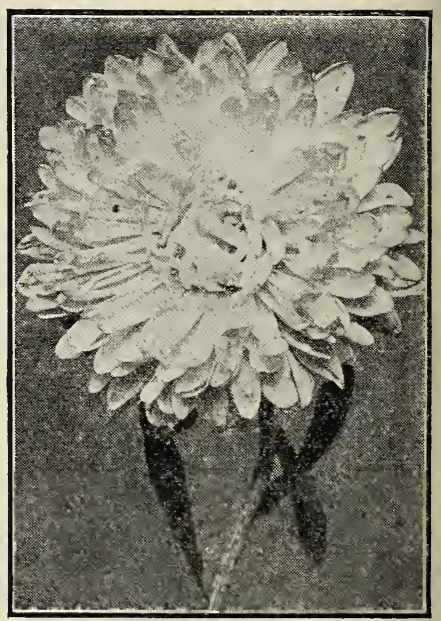

Queen of the Market

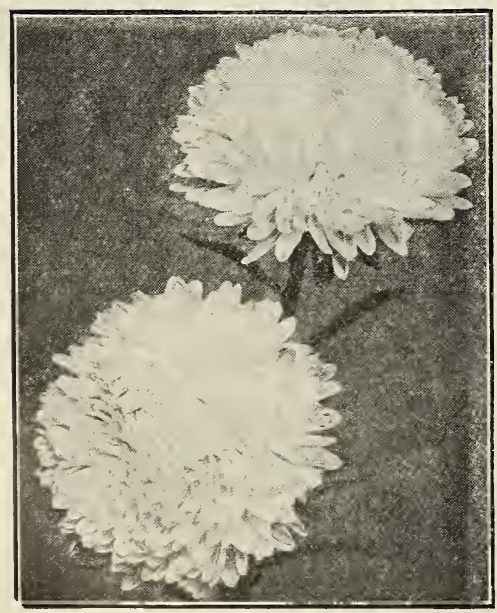

American or Late Branching

\section{New Everlasting or Straw Flower Aster}

This handsome new Aster was found growing among other Asters a few years ago and it has retained its peculiar characteristics during the several years in which it has been grown. It is a real Aster, of beautiful flesh color, and when cut and dried it retains its color and shape as an everlasting flower. If you want something exceptionally fine for dried winter bouquets, try this new Everlasting Aster. Pkt., 10e; 3 plits., 25e, postpaid.

\section{PERENNIAL ASTER}

The Perennial or Hardy Asters are among the showiest of our late-flowering hardy plants, giving a wealth of bloom during September and October, a season when most other hardy flowers are past. They grow freely in any soil.

NEW PERENNIAL HYBRIDS. A fine mixture of the most choice varieties and finest colors. Seed in mixture of colors only. Pkt., 15c; 2 pkts., 25c.

Field grown plants in separate colors-blue, pink, white-at 25c each; 3 for $60 \mathrm{c} ; 12$ for $\$ 1 . \tilde{0} 0$, postpaid.

\section{Special All Seasons' Aster Offers}

One packet each of mixed colors of Giant Ostrich Feather, Queen of the Market, King, Giant Chrysanthemum-Flowered Comet and American Branching-all 5 for $35 c$.
One packet each of New Ererlasting or Straw Flower Aster, Yellow Asters Mixed and New Perennial Hybrids-all 3 packets for 30c. 


\section{Aquilegia (Columbine)}

Early Hybrids (P). A fine assortment of colors of the earliest flowering arieties. Pkt., 10c.

Long spurred Iybrids (Mrs. Scott Eliott's Strain) (P). A wonderful mixture containing all the beautiful tints, tones and color combinations for which this strain is famous, hardly two being exactly alike. This is unquestionably the finest strain of Columbine yet produced. The plants are of strong, thrifty growth with flowers of largest size. Pkt., 15̃c.

AQUILEGLA PLANTS (Long Spurred) (P). Fine assortment of colors. Plants $30 \mathrm{c}$ each; 3 for $70 \mathrm{c} ; 12$ for $\$ 1.75$, postpaid.

ARABIS, Alpina (Rock Cress) (P). One of the earliest and prettiest spring flowers, covered with a sheet of pure white flowers as soon as the snow disappears. Useful for rockeries or edging. 6 to $\delta$ inches. Plit., 10c.

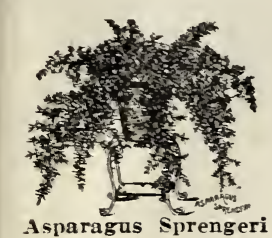

ARCTOTIS, Grandis (A.) Bushy plants, 2 to 3 feet across, with silvery-white, deeply cut foliage. Daisylike flowers $2 \frac{1 / 2}{1}$ inches across; white with blue eye surlilac-blue. Blooms from early July until frost. Fine for cutting. Pkt., 10c.

ASPARAGUS FERN Plumosus (Lace Fern) (H). A graceful pot plant with very finely divided feathery foliage. The finest of the Asparagus Ferns. Pkt., 25c. Plants, 30c each.

Sprengeri (Emerald Feather) $(\mathrm{H})$. A variety of Asparagus Fern with long, drooping branches. Fine for suspended baskets, window boxes, etc. Pkt., 10c. Plants, 25c each.

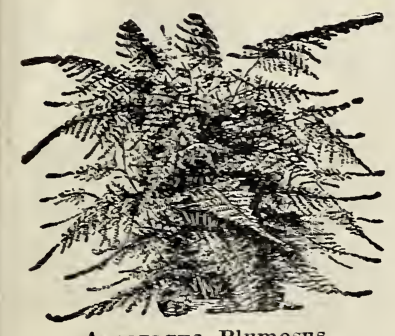

Asparagus Plumosus

\section{BLUE LACE FLOWER}

(Didiscus Coruleus) (A). A beautiful Australian annual which is becoming very popular on account of its soft blue tiful lace-like flowers. The Blue Lace Flower grows into an upright, very much branched plant of about 2 feet in height. Each branch ends in an umbel of light sky-blue flowers which spread out in an umbrella-like fashion, crowning each shoot with a beautiful and delicate head of flowers. The name Blue Lace Flower is most appropriate since the blossoms resemble the most delicate and dainty lace. The many large flower clusters are composed of a great mass of florets on long, graceful stems, are unsurpassed for cut flowers and last unusually long in water. It is very easily grown. blooms freely in the garden from July to October, or unt.

BOLTONIA (P). One of the showiest hardy perennials; 5 to 6 feet. Large Asterlike flowers during summer and autumn; pink or white. Plants 25e each; 4 for $50 \mathrm{c}$; 12 for $\$ 1.00$, postpaid.

BRACHYCOME (Swan Rirer Daisy) (A) Free-flowering, dwarf-growing plants, about 9 or 10 inches in height; covered during the greater part of the summer with a profusion of pretty blue, rose and white cineraria-like flowers. Suitable for edgings, small beds and pot culture. Pkt., 10c.

BRAZILIAN PLUME PLANT (H). A native of Brazil. It is of the easiest possible culture, and seems to do well everywhere, requiring but little attention. It is a strong, rapid grower, throwing many shoots, each of which is tipped with beautiful pink, plume-like flowers. Plants, 30c each, postpaid.

BABY TEARS (Helxine or Irish Moss) (H). A compact, dense growing plant with miniature leaves. Of neat habit, and while forming a rounded mass of moss-like foliage, is of partially creeping or drooping tendency, which adds much to its attractiveness. Fine for shaded window boxes; grows easily under living room conditions. Plants, 40c each, postpaid.
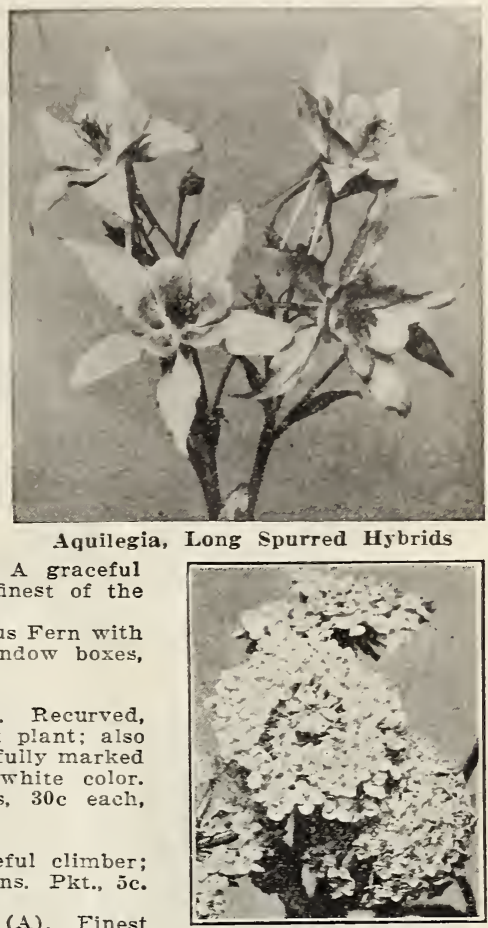

Blue Lace Flower

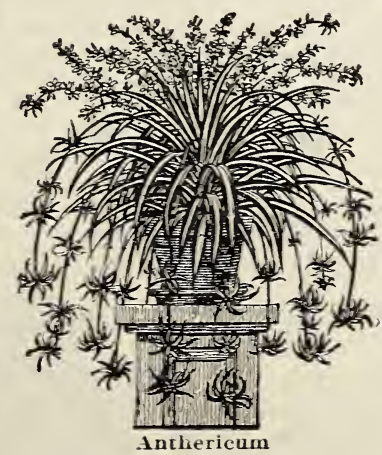

A farorite

\section{BELLIS (Double English Daisy)}




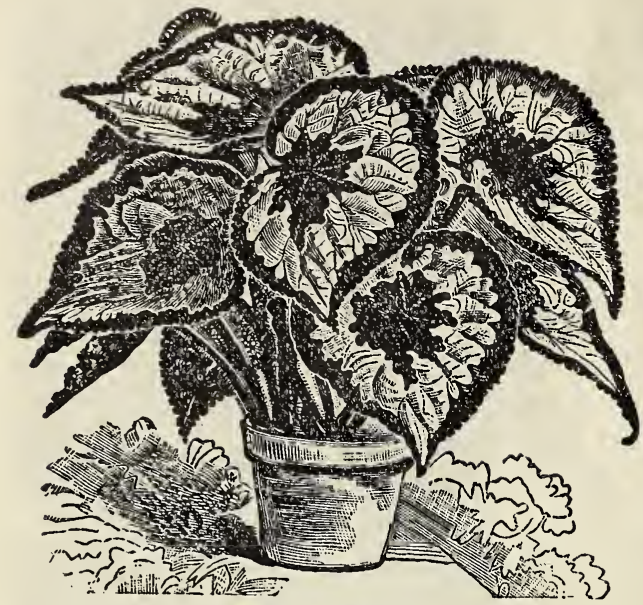

Rex Begonia

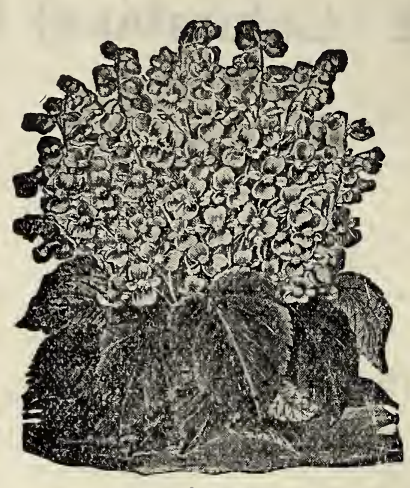

Hardy Begonia

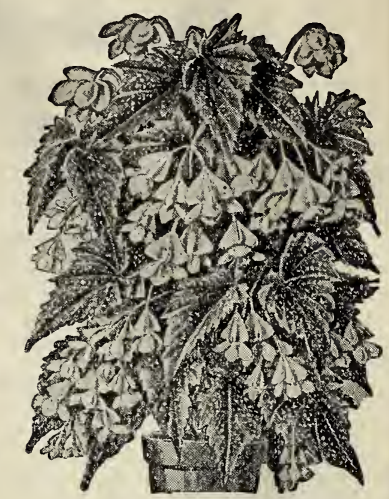

Argentia Guttata Begonia

\section{Begonias}

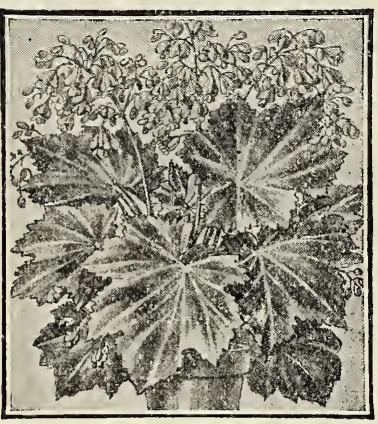

Venus Begonia

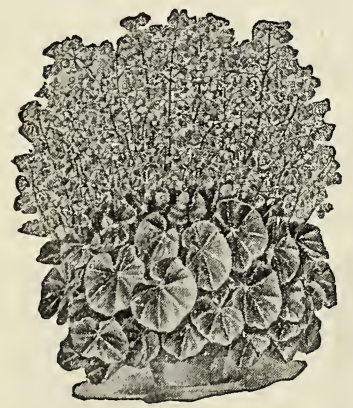

Beefsteak Begonia

ARGENTIA GUTTATA (Tree Begonia) (H). Grows 3 to 4 feet tall, Purple-bronze leaves with silver markings; white flowers. Plants, 35e each, postpaid.

BEEFSTEAK (Feastii) (H). A low spreading Begonia, with circular leaves, red beneath and dark glossy green above, and of heavy texture. Dainty coral-red flowers. The finest pot Begonia for house culture. Grown as easily as a Geranium. Plants, 35e each, postpaid.

CHRISTMAS RED $(\mathrm{H})$. One of the best flowering Begonias. The flowers are bright cherry color, changing to coral-red. Foliage rich, glossy green, shaded deep bronze. The popularity of this Begonia is well deserved from the fact that it is easily grown and very satisfactory both as a winter house plant and for bedding purposes. Plants, 30c each, postpaid.

HARDY BEGONIA (Evansiana). Here is one of the best house and garden plants; a rapid, healthy grower, very profuse bloomer with beautiful foliage and clusters of pink flowers. The plant re-establishes itself in the spring from root tubers. Plants, 45c each, postpaid.

REX (Giant Painted Leaf) ( $H)$. Few house plants are so entirely satisfactory in every way as the Rex Begonias. They are rich in color and beautiful in design and are easily handled under almost any condition. The large, broad leaves, high colorings and exquisite markings make them invaluable as decorative plants for house culture. They make excellent plants for baskets and vases if given plenty of moisture and not exposed to the full rays of the sun. Plants, 45e each, postpaid.

VENUS $(H)$. A new begonia, distinctly different. Its dark, glossy green, deeply cut leaves combined with its free flowering habit, make it one of the most attractive plants grown. Blooms the year around. Plants, 40c each, postpaid.

WATERMELON (H). An excellent house plant for the window or table. The leaves withstand the dry air of rooms better than the majority of plants. Leaves thick and waxy-like, are distinctly variegated white and green, and have the appearance of being powdered with frosted silver. Plants, 35c each, postpaid.

\section{Begonia Seed}

SEMPERFLORENS HYBRIDS $(H)$. As a bedding plant, it ranks with Coleus and Geraniums. Of sturdy growth, about one foot high, forming dense bushes, which from May until frost, are completely hidden with flowers. As a house plant, it blooms throughout the entire year. A fine mixture of colors, from pure white to deepest crimson. Pkt., 10c.

VERNON $(\mathrm{H})$. Bright orange-carmine flowers; deep red foliage. A fine house plant and unsurpassed as a bedding variety. Pkt., 10c.

\section{Bougainvillea \\ (Chinese Paper Plant)}

Brilliant rosy-crimson blossoms, produced from early March until midsummer. A most desirable window garden plant. Can be trained into a beautiful outdoor ciimber in the South. Plants, 30e each, postpaid.

\section{Brugmansia}

\section{(Angel's Trumpet)}

Large tropical leaves with trumpet-shaped flowers, pure white and as fragrant as jasmine. Blooms indoors in winter and in the garden in the summer. Plants, 45e each, postpaid.

\section{CERASTIUM (Snow in Summer)}

TOMENTOSUM (P). Silvery-white foliage and snow white flowers; hardy perennial; 4 inches in height; suitable for the rockery, or for carpeting dry, sunny spots, or covering graves, and unsurpassed as a low border plant.
Pkt., 10c. Plants 25e each; 4 for 50c; 12 for $\$ \mathbf{1 . 0 0}$, postpaid.

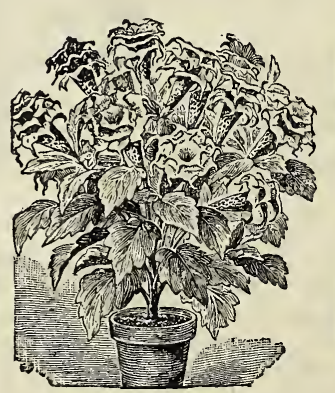

Brugmansia

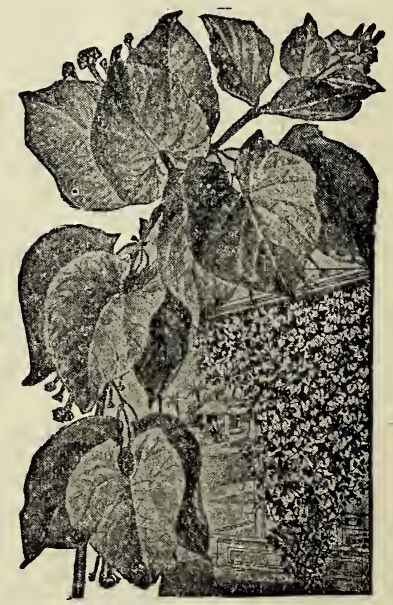

Bougainvillea 


\section{CALENDULA (Pot Marigold)}

One of the best and showiest free flowering hardy annuals. Blooms from early summer until killed by frost; particularly bright in late fall. Valuable also for pot culture, blooming freely in winter and eariy spring.

METEOR (A). Large double flowers, striped orange and cream. Pkt., 5c.

ORAXGF IIIXg (A). Extra fine, double, rich orange-red variety; flowers over 3 inclies in diameter. Plit., 8c.

SULPII R CROWx (A). Large, double, sulphur yellow, Pkt., 5c.

FINEST MIXED (A). Double sorts mixed. Pkt., 5c.

\section{CALLA}

FLLIOTTIAx (Yellow Calla) (H). Beautiful pure golden yellow flowers. 4 to 5 inches broad. The leaves are attractively marked with white spots. Easily grown. 35c each; 3 for $\$ 1.60$.

AFTHIOPICA (White Calla) (H). Our stock of seeds and bulbs are an exceptionally fine strain of the old White Calla, and much superior to the $n$ wr snits. Flowers are pure white. unusually large. held high, and on siff stems. Plit., 10c. Bulbs, 30c each; 3 for Sje.

\section{CAMPANULAS (Bellfowers)}

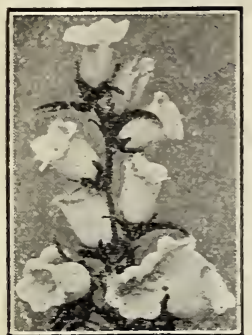

Campanula Medium

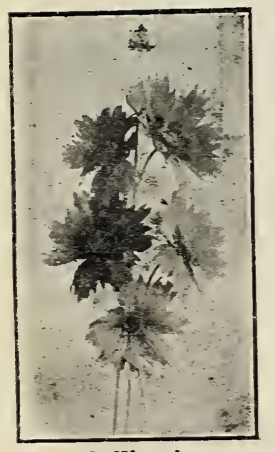

Calliopsis

CALICANTHEMA (Cup and Saucer) (B). A fine type of this much prized garden plant. Large, semi-double blue, white, rose and striped flowers, each resembling a cup and saucer. Seed in mixture of colors only. Pkt., 10c.

CARPATICA (Hare Bell), Blue (P). A pretty species growing in compact tufts, not exceeding 8 inches high; flowers clear blue, held erect on wiry stems. It begins blooming in June, continuing until cetober. As an edging for a hardy border or for the rockery. it is unsurpassed. Pkt., 10c.

CARPATICA. White (P). A pure white-flowered form of the abore. Pkt., 10c.

CARPATICA, Mixed (P). White and blue shades. Pkt., 10c.

MEDrCI (Canterbury Bell) (B). The old-fashioned sort with beautiful. large, bell-shaped blossoms of blue, rose and white. Seed in mixture of colors only. Pkt., 10c.

PERSICIFOLiA (Peach Bells), Blue (P). One of the finest Campanulas, with large. handsome blue, bell-shaped flowers. 2 to 3 feet high. Pkt.. 15c. PERSICIFOLIA, White (P). A pure white-flow-

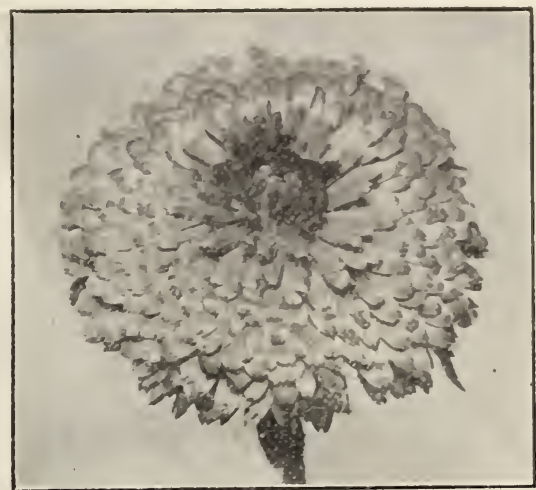

('alendula

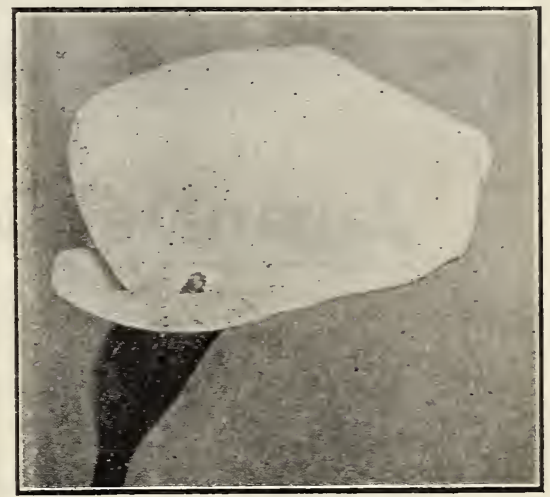

Calla Aethiopica ered form of the above. Plit., 15c.

PERSICIFOLIA, Mixed (P). White and blue shades. Pkt.. 15c.

PYRAMIDALIS (Chimney Bellfower). Blue (P). A beautiful stately plant; 4 feet; rich blue saucer-shaped flowers borne on long stems. Pkt., 10c.

PYRA.IIDALIS, White (P). The white Chimney Beilfower. Pht., 10c.

PYRAMIDALIS. Mixed (P). Thite and blue shades. Plit.. 10c.

PRIZE MIXTERE. A fine mixture of the perennial Campanuias. Pht., 10c.

\section{CANARY BIRD VINE}

A beautiful ranid growing annual climber. the charming little canary-yellow blossoms bearing a fancied resemblance to a bird with wings half expanded. The sprays of flowers are very artistic and, when cut, keep in good condition for a week. Pkt., 8c.

\section{CALLIOPSIS}

Beautiful, shnwy. free-flowering plants, of the easiest culture, doing well in any sunny position. blooming all summer and excellent for cutting and massing. By keeping the old flowers picked

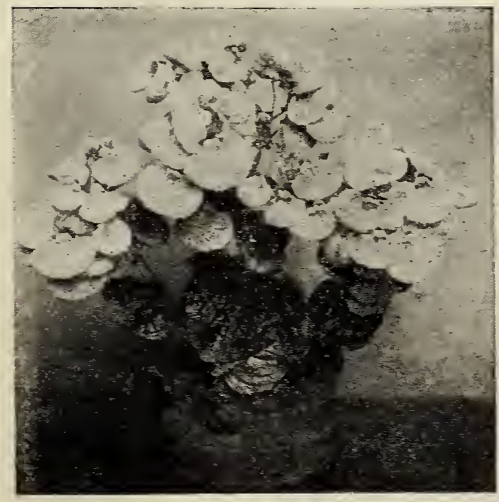

Calceolaria CRIMSON KING (A). A fine dwarf sort, 9 inches high; color rich, velvety crimson-garnet. Pht.. 8c. DWARF MIXED (A). Finest mixture of dwarf varieties; yellow, orange, TALL DOCBLE MIXED (A). Finest mixture of double varieties. Pht.. 8c. TALI SINGLE MEED (A). A superb mixture of all colors. Pkt., 5 c.

\section{CALCEOLARIA}

An ornamental house plant, producing a mass of beautiful pocket-like fowers in the spring; a universal favorite with florists. The Calceolaria is grown from seed. Our select strain of seed is, we believe, the finest in cultivation; flowers large in size and beautifully spotted and blotched in exceedingly rich and varied colors; rery free flowering. Pkt., 35c; 3 pkts., $\$ 1.00$.

\section{CHINESE LANTERN PLANT}

The Chinese Lantern Plant (Phrsalis Franchetti) is a hardy, perennial variety of Ornamental Winter Cherry. which is grown for its very attractive balloon-like pods, which turn bright red and resemble Chinese paper lanterns. May be dried for winter decorations, being very fine at Christmas time. Pkt.,

10c. Plants, 25c each; 3 for 50 c; 12 for $\$ 1.25$, postpaid. 


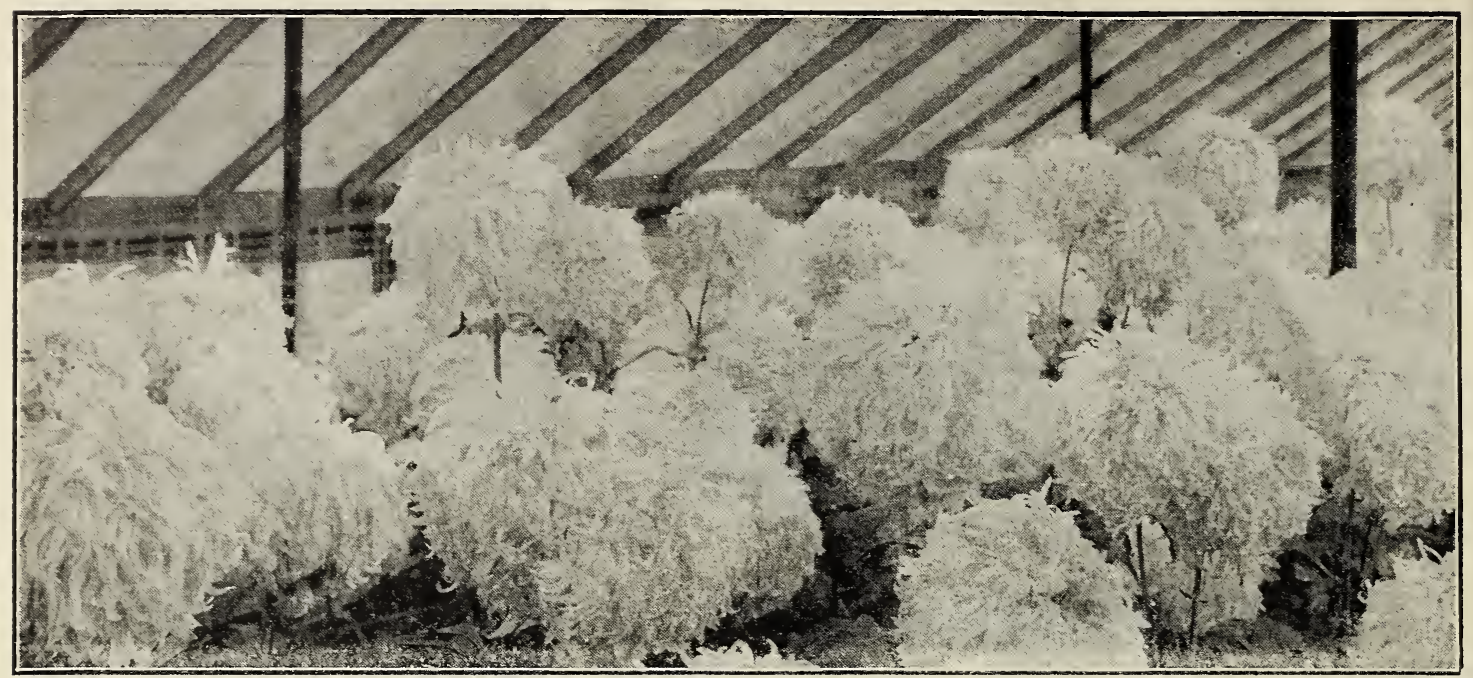

Japanese Chrysanthemums

\section{Japanese Giant Chrysanthemums}

The Chrysanthemum is the queen of autumn flowers. Nothing is more beautiful as house plants, in the late fall and early winter, than these large, fluffy, Japanese varieties. For massive blooms, grandeur of colors, ease of culture and certainty to fiower there is no plant that will surpass them. The endeavor of nearly all growers has been, in late vears, to introduce varieties which will produce the largest and finest blossoms for exhibition purposes. It is from these varieties that this seed is saved. These plants are easily raised from seed. Almost all the new and striking varieties are the result of plants grown from seed, and the amateur is as liable to originate new and splendid varieties as is the professional florist. They are of the easiest culture and always give satisfaction as house plants. The blossoms you get will surprise you with the odd and beautiful forms of the fiowers and abundance of bloom. If you want a magnificent collection of these gorgeous Chrysanthemums-red, white, yellow and pink-you will make no mistake in getting a packet of our select seed. This seed is not sold in any seed assortment or mixture, and the only way to be sure of getting the genuine is to buy it in our sealed pachets.

We sell the seed in sealed packets only, and guarantee it to be from the genuine large flowered Japanese varieties. Pkt., 25̃c; 3 pkts., 60c, postpaid.

\section{Choice Chrysanthemum Plants}

LOUIS BOEHMER. Lavender pink, shaded with silver pink on ends of petals. Good size. 35̃c each.

CHRISTUAS CHEER. A fine late pink. Tsually produces flowers during the holiday season. 30c each.

COL. D. APPLETON. At one time the most widely grown yellow in cultivation. 25c each.

HARVARD. Rich crimson. Large blooms; very showy. 30c each.

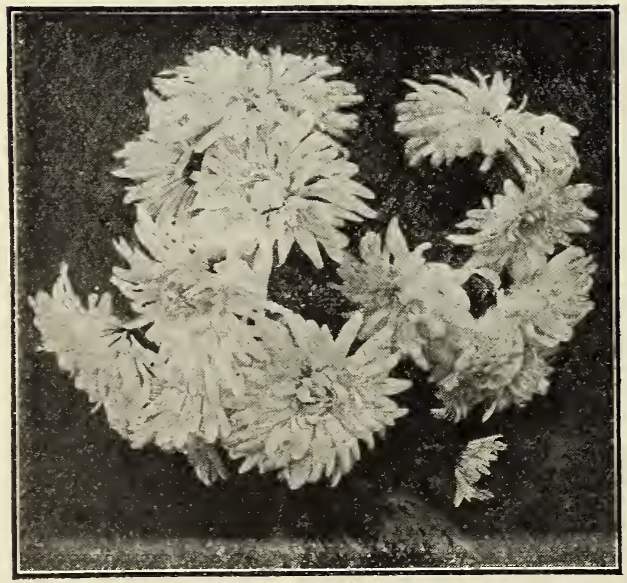

Hardy Chrysanthemums
OCOxTo. A splendid white. Extra large in size with broad, incurved petals of snowball type. 25c each.

PACIFIC SCPREME. Bright pink. Comes into bloom about the last of August. 30c each.

CHRYSOLORA. A new yellow variety. Large, beautiful blooms. $30 \mathrm{e}$ each.

WH'TE IrTETLETOE. Bluish white flowers of exquisite form and finish. 2ac each.

\section{Hardy Perennial Chrysanthemums}

There is probably nothing else in the outdoor fall-blooming plant line that is so valuable as the Hardy Perennial Chrysanthemum. We have no seed to offer, but can supply plants of all types, kinds and colors, in fine mixture, at $\$ 1.50$ per half dozen or \$2.50 per doz. We ean also furnish the large-flowered varieties in separate colors-red, pink, white and yellow-at 35e each; 4 for \$1.20.

\section{Annual Chrysanthemums}

DOUBLE WHITE (A). Valuable summer-flowering border and bedding plant, which bears large quantities of blooms which are excellent for cutting, and quits distinct from the autumn flowering varieties. Pkt., 8c.

DOUBLE TELLOW (A). Same as Double White, except the color, which is bright yellow. Pkt., 8c.

DOUBLE HIXED (A). Pkt., 5e.

\section{Cigar Plant}

Scarlet, pendulous flowers; neat, compact habit. Never out of flower the year around. No better house or basket plant to be had. 20̃c each, postpaid.

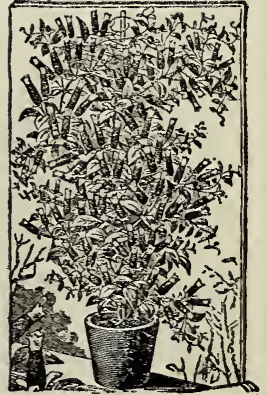

Cigar Plant 


\section{CARDINAL CLIMBER (A)}

The most beautiful and brilliant climber ever grown. Strong, rapid grower, attaining a height of 25 feet, with beautiful fern like foliage and literally - covered with a blaze of fery cardinal-red flowers from mldsummer to frost. Pkt., 10c.

\section{CARNATIONS}

MARGARET (A). These are deservedly the most popular Carnations with he amateur as they begin flowering in four months after seed is sown. Sown early, the plants will bloom during the late summer and early fall, and by ear be had in blonm all winter long if grown in the conservatory or greenhouse. A fine mixture of colors. Plit., 10c.

PERPETIAL CHABALD (B). This is a particularly fine strain of giantfowered Carnation which will bloom the first year if seed is sown early in the Spring. The plants make comnact bushes 2 to 3 feet tall and bear, on tall stems, a mass of nicely fringed. intensely fragrant double fiowers. In many sections of the country they do well outdoors, but it is when grown in the greenhouse that the flowers develop to their best. Choice mixture of colors. Plet. 10c.

HARDY PEREXNIAL (P). The true hardy outdoor Carnation. A beautiful strain which blooms in great abundance all summer. Excellent for cutting and very ly Comes in separate co: r - -pink, red, white and yellow. No seed to offer. Plants, 35c each; 4 for $\$ 1.00$, postpaid.

\section{CELOSIA}

CHINESE WOOL FLoWER (Celosia Childsii), Crimson (A). One of the most magnificent garden annuals ever introduced. Commences blooming early and continues until frost. 2 to 3 feet high; wool-like blossoms in immens clusters, often measuring 2 feet in circumference. Pkt., 10c.

Pink (A). A new variety of Chinese Wool Fiower, with magnificent glowing pink flowers. Pkt., 15̃e.

Yellow (A). Gorgeous yellow blossoms. Pkt.. 15c.

Mixed (A). A mixture of all 3 colors of Chinese Wool Flower. Pkt., 1jc.

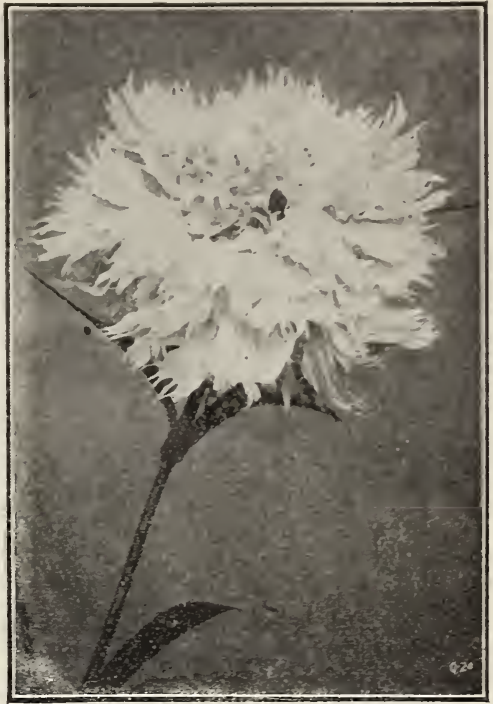

Perpetual Chabaud Carnation

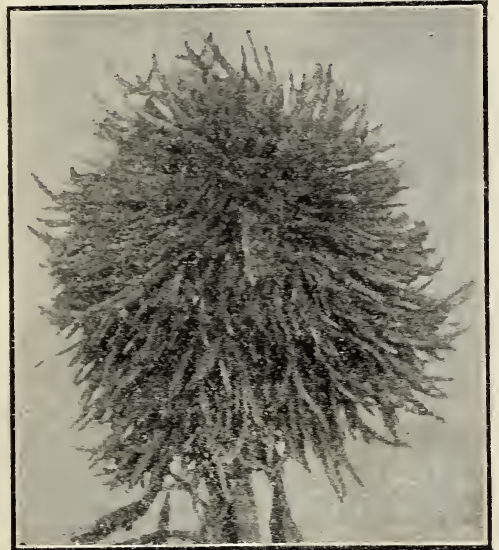

Chinese Tool Flower (Celosia Childsii)

COXCoMB (Celosia Cristata) (A). Free-blooming annuals, growing best in not too rich and in rather light soil. Make grand border plants and are attractive for pots. Fine mixed. Pkt., 8c.

ENERLASTIYG CELosLA (Celosia Spicata) (A). Light lilac-pink flowers, borne in elongated heads carried on long, substantial stems. Easily dried for winter bouquets. Pkt., 10c.

PLCMOSA (Plumed or Feathered Celosia) (A). Of pyramidal growth, attaining a height of 3 feet and producing numerous brilliant, massive plumes which resemble ostrich feathers and wave gracefully above the foliage. Choice mixture of red and Jellow shades. Pkt., 10c.

\section{CACTUS}

CACTUS SEED -30 Varieties. Cactus make most interesting house plants, extremely odd and curious, and many have gorgeous and beautiful blossoms sweet scented, and bloom profusely. These oddest of all plants grow in many shapes and sizes, are easily grown, thrive and bloom with rery little care, and endure the heat and dryness of the ordinary living room. Mruch pleasure may be derived in growing them from seed. Everyone is delighted and surprised at the odd appearance of a Cactus just sprouting. If you desire a fine collection of rare rarieties, sow the seed in pots or boxes in a warm room in moist sand, and the seed will grow quickly. We have fresh. seed of a mixture of 30 choice varieties. Pkt., 10c; 3 pkts., 25c. Plants 50c each; 3 for \$1.00: 7 for $\$ 2.00$; each plant a different variety and delivered to you prepaid.

\section{CENTAUREA}

CrANts (Cornflower o- Bacheior's Button), Double Yixed (A). A fine mixture of different colors and shad st. Pkt., õc.

GWMOCARPA (Dusty Miller) (A). Silvery-white, finely cut leaves; used for bedding (10c.

DIPERIALIS (Giant Sweet Sultan) (A). The finest of all Centaureas for cut-flower purposes. Beautiful. sweet-scented, artistic-shaped flowers; borne on long, strong stems and when cut will last for several days in good condition. Plst., 10c.

MONTANA (Perennial Cornilower) (P). Vigorous grower of easy culture; 2 feet high; large riolet-blue flowers from July to September; excellent for cutting. Plit., 10c. Plants, $25 \mathrm{c}$ each.

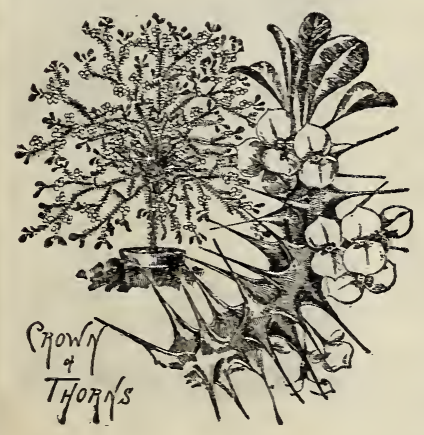

\section{CLEOME PUNGENS (Giant Spider Plant)}

A fine annual plant for large beds and for interspersing in the shrubbery border. 4 to 5 feet high, with showy rose-colored flowers of peculiar and interesting shape. suggesting spiders. Plants given sufficient room to develop their full beauty are very striking and bloom every day in the season. Pht., 10c.

\section{Crown of Thorns}

Euphorbia Splendens (H). A curious plant, with thick, fleshy, twining stems which are covered with spines nearly an inch in length. The foliage is bright green and flowers are a beautiful coral pink. Plants, $40 \mathrm{c}$ each,

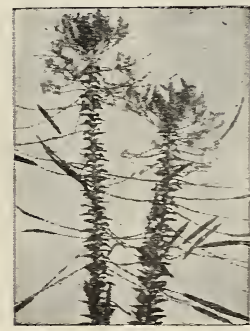

Cleome Pungens

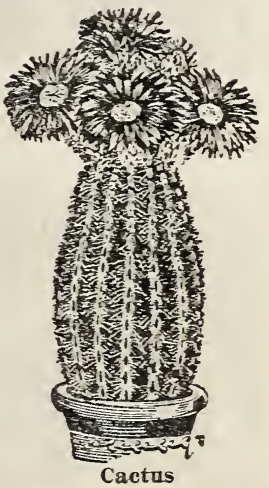

Cactus

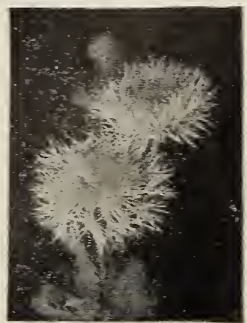

Centaurea Imp. 


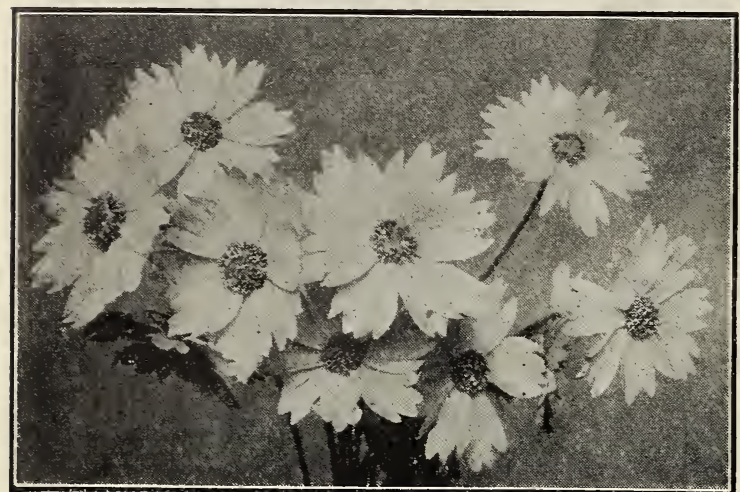

Coreopsis

\section{Clarkia}

ELEGANS DOCBLE (A). A pretty and easily grown annual, and one of the most satisfactory for cut flowers, Does well in either sun or shade, growing 2 to $21 / 2$ feet high, with beautiful double flowers, which open in water when cut. Our mixture contains a fine variety of colors, from pure white, flesh pink, bright pink, rose and salmon to the darker shades of orange, orange-scarlet, salmonscarlet, etc. Plit., 10c.

\section{COLEUS}

RAINBOW HYBRIDS (H). The Coleus is the most handsome foliage plant obtained from seed, and our Rainbow Hybrids are very fine, being surpassed only by our Large-Leaved Hybrids. Richly colored, and a most attractive and novel foliage plant for the house and for bedding out. Plit.. 10c. Plants, 20c each, postpaid.

COBAEA SCANDENS (A). Also called Cup and Saucer vine or Cathedral Bells. A handsome annual climber of rapid growth, attaining a height of 30 to 50 feet during Will cling to any rough surface. Large, bellthed purplish-lilac flowers. Pkt., 10c.

COREOPSIS, Lanceolata Grandifiora (P) This is one of thaped, purplish-lilac flowers large, showy bright yellow flowers, produced in greatest abundance from June until frost. As a cut flower they stand near the head of the list of perennials, having long stems and lasting in good conditi n a week or more. Pkt., 5c. Plants, 25c each; 4 for 50c; 12 for \$1.25. postpaid.

COMET PLANT (Acalypha Sanderii). A most desirable addition to any collection of house plants. From the axil of each of the attractive dark green leaves springs a long drooping spitie of glowing crimson-scarlet, nearly an inch in diameter and from 18 to 24 inches long, very veivety in texture, reminding one of a very long piece of brilliant chenille. Plants, 30c each, postpaid.

\section{CANDYTUFT}

The Candytufts are popular everywhere, and considered indispensable for cutting. Seed sown in April, flowers in June. Successive sowings should be made at intervals. Hardy and easy to grow. GIANT HYACINTH-FLOWERED (A). The finest of all; immense spilies of large, pure white flowers. Pkt., 8c.

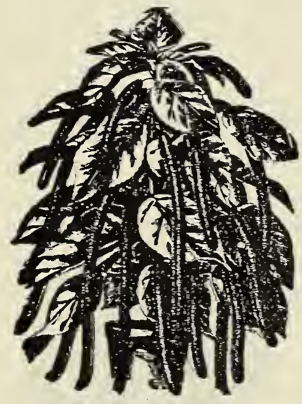

Comet Plant

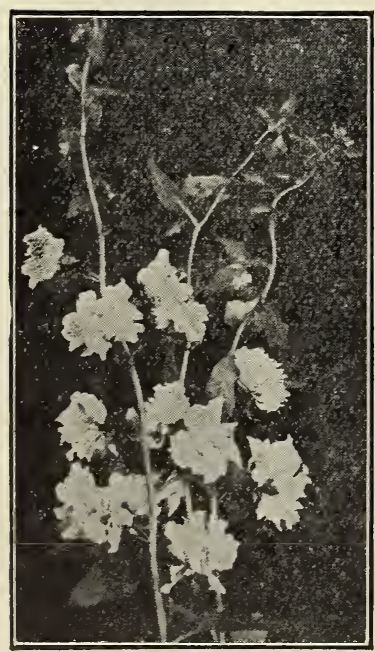

Clarkia
CRLISON (A). Very fine; rich and showy. Pkì., 8c.

PINT (A). One of the finest for edging, bedding and cutting. Plit., 8c.

WHITE (A). Fine for borders. Pkt., 5c.

ALL COLORS MIXE (A). Pkt., 5c.

PERENXIL CANDYTCFT (Tberis), Sempervirens (P). A profuse, white-blooming, liardy perennial. coming in flower early in the spring. Much used for cemeteries, rockeries, etc. Pkt., 15e.

QCEEN OF ITALY (P). Dwarf bushes covered with large rosylilac flowers. Per nnial but usually treated as an annual. Pht., 10c.

\section{COSMOS}

Beautiful summer and autumn blooming plants, producing thouands of artistic flowers and furnishing an abundance of cut blossoms for autumn decorations when other Howers are scarce. The double varieties are the best of all for cut flowers, the blooms lasting coniderably longer than the single varieties.

ACTCMN GIANTS (A). Gigantic flowers with broad, orerlapped petals of splendid substance; borne on very long stems. All colors mixed. Pkt., כ̃e.

GLANT SCMMIER, Crimson (A) As early as the earliest and continues until frost. Neariy as large as the late sorts. Pkt., 8c.

GIANT SUMMER, Pink (A). A beautiful rosy-pink flowered form of the above. Pkt., sc.

GIANT SCMnER, White (A), Pure white. Pkt., 8c.

GIAT SCMMER, Mixed (A). All three colors, mixed. Pkt., 8c.

EARLY-FLOWERED DOUBLE, Crimson (A). Pkt 20c; 3 pkts., 50c.

EARLY-FLOWERED DOUBLE, Pink (A). Pkt., 20c: 3 pkts., 50c.

EARLY-FLOWERFD DOUBLE, White (A). Pkt., 20e: pkts., 50c.

EARLY-FLOWERTD DOUBLE, Mixed (A). Pkt., 25c. YELLOW COSMOS “FLONDYKE”' (A). Golden yellow flowers, $2 \frac{1}{2}$ to $31 / 2$ inches across; long stems. To get this variety in bloom before frost in the Northern States it should be grown in pots or boxes, so that the roots are confined, thus throwing it into flower sooner. Plit., 10c: 3 pkts., 25e.

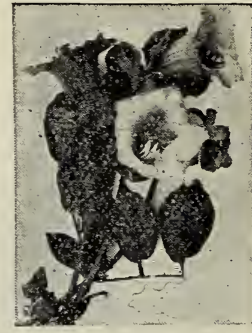

Cobea Scandens

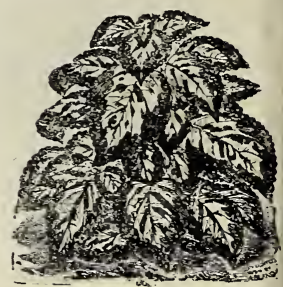

Coleus

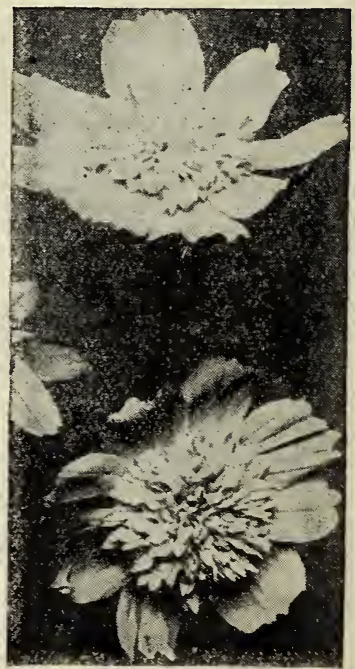

Double Cusmos 


\section{Cyclamens}

Cyclamens are, without question, one of the best and most beautiful house plants. specialist, seed being selected only from plants of superior bloom and foliage. The flowers are unsurpassed for size, color ani substance. The secd we offer is a mixture of bright red, dark red, light pink, deep pink, salmon, white, white with carmine etc. In fact, the colors range from white to darkest crimson, with all intermediate shades. Seed should be sown in shallow pans containing a mixture of finely sifted soil and leaf-mold. Keep warm and moist until the seeds sprout. which usually talkes four weelss. When the plants are large enough to handle, they should be transplanted into small pots to be repotted into larger ones as the plants increc

Prize Mixture of Giants $(H)$. Extra large and choice. Plit., (10 seeds) 20c; 3 plits., 50c; 10 plists., \$1.50.

Good Mixture (H). A very fine strain, but not as large as our Prize Mixture of Giants. Plit., (10 seeds) 15c; 2 plsts., 25c; 10 plsts., \$1.00. Plants, 40c each.

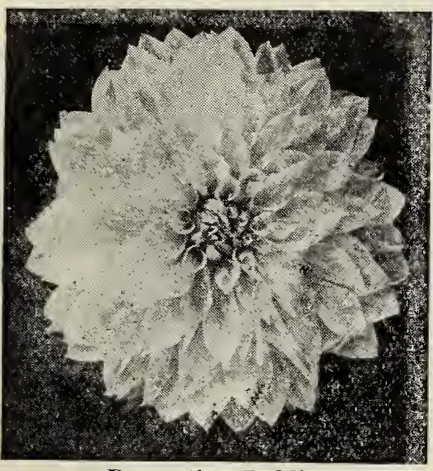

Decorative Fahlia

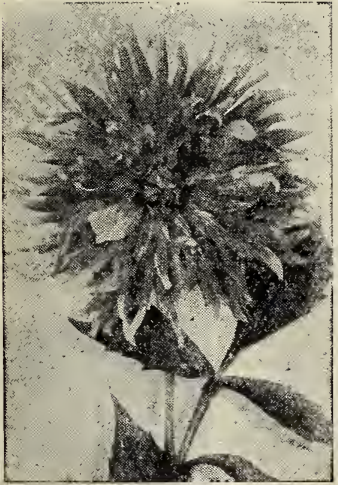

Cactus-Flowered Dahlia

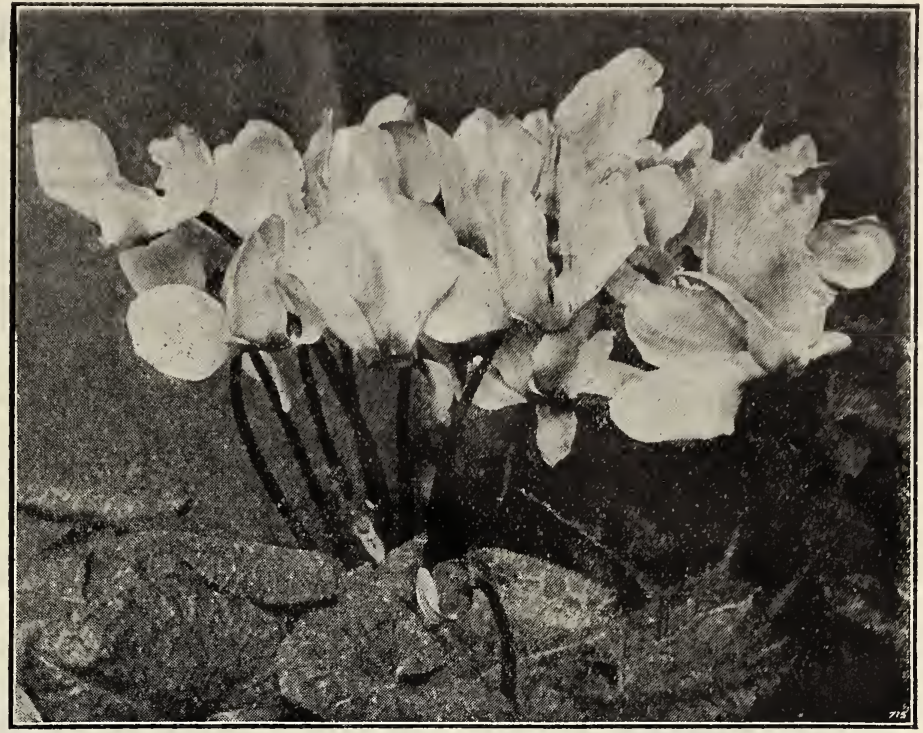

Prize Giant Cyclamen

\section{Giant Exhibition Cineraria}

Our Giant Exhibition Strain of Cineraria is unsurpassed in size of flower, bright colors, and delicate fragrance. Plants grow into round bushes, completely covered by the massive flower-heads. For Christmas blooming, seed should be sown in April; for blooming during early spring, June or July sowing should be made. Sow seed in shallow boxes containing a fine, fairly sandy soil. Keep shaded and moist until seedlings appear. Transplant into other boxes as soon as they are large enough to be handled, and into small pots when the plants attain a fair size. Cinerarias delight in a rich soil, cool and airy rooms and plenty of light. Pkt., 25̃c; 3 pkts., 60c. Plants, 35e each, postpaid.

Cineraria Radiata (STAR CINERARIA). A beautiful flowering plant for the conservatory during the late winter and early en panicles of starry flowers in many pleasing shades of crimson, rose, blush, white, azure and violet. The extreme grace and elegance of the plant and flowers make them wonderfully effective for the house and conWhite Leaved Cineraria MARTCANDUDSSIMA (Dusty Miller). These, as well as the white-leaved Centaureas offered on page 35 , are called "Dusty Miller." Fine for bedding, ribbon beds and margins; prized for their beautiful downy, silvery foliage. Half hardy perennials, but should be treated as annuals: 2 feet. Pkt., 10c.

\section{Cypress Vine}

One of the most popular climbers. Very delicate fern-like foliage, and masses of small, bright, star-shaped flowers.

SCARLET (A). Pkt., 5c.

MIXED (A). Scarlet and White. Pkt.,

\section{DAHLIA SEED}

Dahlias are as easily grown from seed as nasturtiums, and will bloom the first year if seed is sown early.

DOUBLE CACTUS-FLOWERED. Characterized by long, narrow, pointed, tubular and twisted petals of graded lengths, giving the layered flowers a very striking and attractive appearance. Excellent mixture of the finest varieties. Plit., 20c.

DOUBLE DECORATIVE. Flowers full to the center; thick but not ball-shaped, with broad, flat petals. Choice mixture of large flowered varieties. Plit., 20c.

PEONY-FLOWFRED. A very atiractive type of Dahlias. Flowers of large size and semi-double form, with a whorl of petals often covering the yellow center. Free blooming and wonderful for garden display or for cutting. Pkt., 20c.

CHOICE DOCBLF. A fine mixture of Decorative, Show and PeonyFlowered varieties. Pkt., 15c.

SINGLE MIXED. Exceedingly showy; a blaze of color all the season. Pkt., 10c.

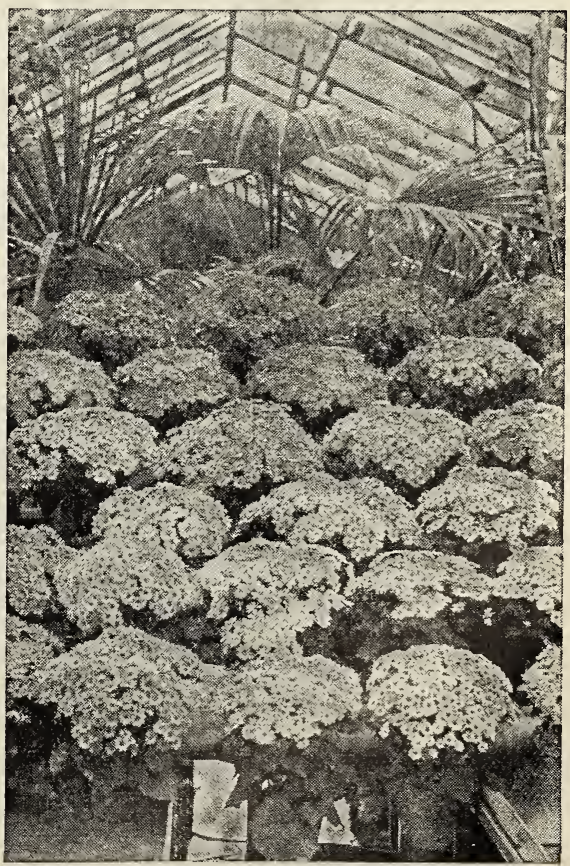

Giant Exhibition Cineraria 


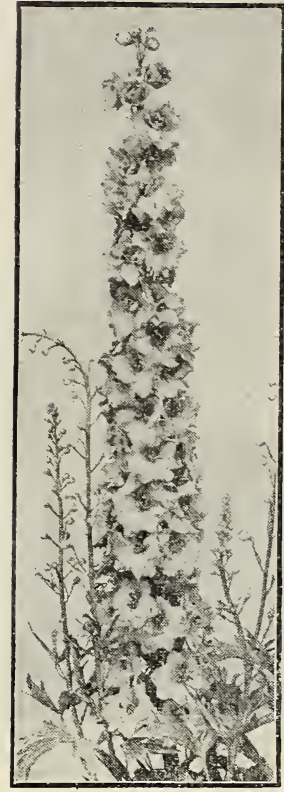

"Hollyhock" Delphinium

\section{Burgess' Choice Delphinium}

(Hardy Perennial Larkspur)

The Delphinium is, beyond question, the Queen of all blue flowers. Their wonderful stateliness, loose, graceful shape of flowers, and fine colors make them suitable for most any floral work; very effective in borders and planted among the shrubbery; and as cut flowers they have
few equals.

BELLADONNA (Everblooming Hardy Larkspur) (P). One of the most continuous and free blooming Delphinium. The clear turquoise blue of its flowers is unsurpassed for delicacy and
beauty. 3 to 4 feet. Plit., 20c.

BFLLAMOSUM (P). A dark form of the popular Belladonna with intensely rich. deep blue flowers. It is better than Formosum, grows taller, and will not mildew like Formosum. Pkt., $20 \mathrm{c}$.

CHINESE, Large-Flowered Blue (P). A very pretty variety with fine feathery foliage and intense gentian-blue flowers in open panicles. $2 \frac{1}{2}$ to 3 feet. Pkt., 10c. Plants, 30c each; 3 for \%0c; 12 for $\$ 1.75$, postpaid.

CHINESE, Large-Flowered White (P). A pure white form of above. Plkt., 10c. Plants, 30c each; 3 for $70 \mathrm{c}$; 12 for $\$ 1.75$, postpaid.

CHINESE, Everblooming Hybrids (P). A wonderful mixture of many shades of blue, white suffused with blue, and pure white with yellow eye. Bloom from early summer until late fall. Pht., 1ŏc.

GOLn VIEDAL HYBRTDS (P). This is unquestionably the best and finest of the Belladonna tropes in $b$ - secured anywhere. The range of color varies from the palest shade of blue to the deepest indigo-blue and royal purple with many intermediary pastel tones of mauve, pink, and lavender blendings. Among these new hybrids are flowers of huge size, in both single and double forms. This strain has been raised from seed saved from the finest named kinds. Those who wish to perfect their already prized borders cannot afford to overlook these wonderful hybrids. Plt.. 20c: 3 pkts.. 50c; oz., \$1.0̄0. Plants 30c each; 3 for $75 \mathrm{c} ; 12$ for \$2.00, postpaid.

NEW HOLLYHOCK STRAIN (P). A new race with spire-like spikes. The chief distinguishing features of the "Hollyhock" Delphiniums are the extraordinary length and the tapering shape of the spikes; the indescribably rich and varied tints; the very remarkable extension of the flowering period-many bloom well into August; and their resemblance to Hollyhocks. Pkt., 30c; 2 pkts., 50c.

SCARLET QUEEN (P). Magnificent long spikes of scarlet flowers. Pkt., 35̃c.

\section{DIGITALIS (Foxglove)}

One of the most popular and highly ornam ntal hardy plants. Succeeds under almost all conditions and with but little attention will give a wealth of flowers during July and August.

GIANT SHIRLEY (P). A magnificent strain, with enormous spikes, 5 to 7 feet in height and flower-heads over 3 feet long. Colors range from white and shell-pink to deepest rose, and attractively spotted with crimson-maroon and chocolate. Mixed colors only. Pkt., 15c.

GLOXINIAEFLORA (P). A fine strain of the ordinary Foxglove, with purple, rose and white Gloxinia-like flowers, handsomely spotted, and on long spikes. 2 to 4 feet. Seed and plants in mixture of colors on!y. Pkt., 12e. Plants, 30e each; 3 for $70 \mathrm{c} ; 12$ for $\$ \mathbf{1 . 7 5}$, postpaid.

\section{DICENTRA EXIMIA (Everblooming Bleeding Heart)}

An everblooming form of an old-fashioned favorite. The beautiful finely cut foliage and showy racemes of graceful heart-shaped pink flowers are always attractive. It does not grow as tall as the old-fashioned Bleeding Heart, but produces its showy pink flowers from April until August. Too much cannot be said for this fine border plant, as it is equally at home in full shade or sun, and perfectly hardy everywhere. Will grow in any climate under any conditions. Plants, 40c each; 3 for $\$ 1.00 ; 12$ for $\$ 3.00$, postpaid.

\section{GIANT FLOWERED DAISIES}

SHASTA DAISY, Fing Fdward $(P)$. The largest of all daisics, flowers frequently measuring more than 5 inches across. An improvement over the common Shasta Daisy, and will stand the winter where the old variety freezes out. The flowers are pure white, with long stems; a mass of bloom during September and October; a beautiful cut flower, remaining in good condition a week or more. Pkt., 10c. Plants 25c each; 3 for 60c; 12 for \$1.75, postpaid.

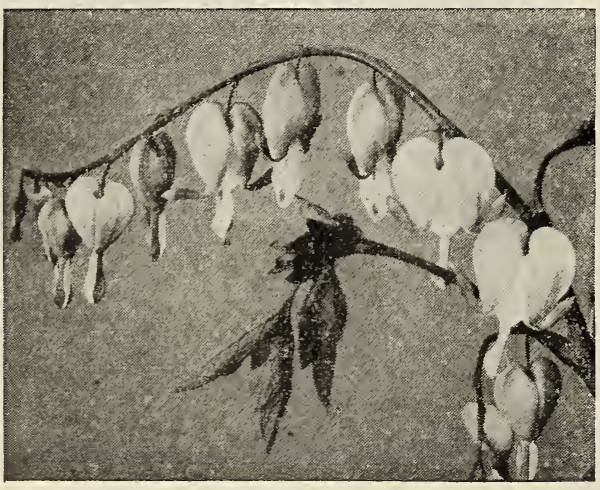

Dicentra (Bleeding Heart)
DECORATIOY DAY DAISY (P). Very similar to the Shasta Daisy except that the flowers are not quite as large and are in full bloom by Decoration Day. A valuable cut flower va3 for ซ̃̃c: 12 for $\$ 2.00$, postpaid.

\section{READ OUR GUARANTEE ON PAGE 1}

\section{DRACAENA INDIVISA}

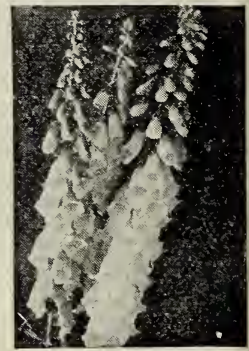

Digitalis
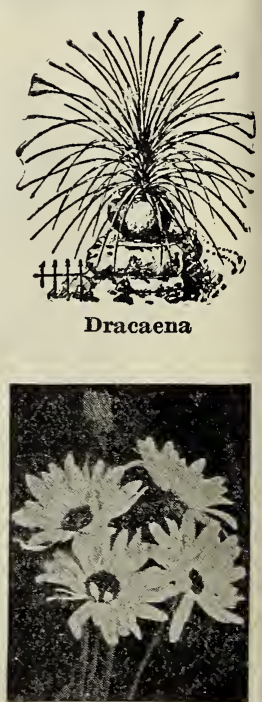

Shasta Daisy
Often called the "Fountain Plant." Slender, drooping leaves of several shades of grcen with delicate stripings of yellow and red. Very graceful in habit and an exceedingly handsome ornamental plant for the conservatory, window box, vase or urn. Pkt., 10c. Plants, 25c each, postpaid.

\section{EVERYTHING DELIVERED PREPAID}

All seeds and plants listed in this catalog are delivered prepaid, except where we plainly state otherwise. 


\section{Dianthus or Pinks}

Few fowers can equal the old-fashioned Pinks in beauty and profusion of blocins. They are easily grown and do well in almost any kind of soil and location. The biennial varieties are usually treated as annuals, and are a mass of bloom within a few weeks after seed is plant.d. Excellent for cutting. As a rule. they survive the winter if given slight protection. flowering abundantly the following season.

CHINEsE, louble (B). Sometimes called Indian Pinks. Handsome clusters of very double flowers; many bright colors. Pl., 5e.

FIREBALL (B). Large, double; rich, blood-red; splendid for cutting or as a border. Pkt., $10 \mathrm{c}$.

HEDDEWIGI, Giganteus (Large Flowered Single Japanese Pinks) (B). Flotwers 2 to 3 inches in diameter: borne very profusely and make a wonderful show in beds or borders. The range of coiors includes many shades of pink, rose and also pure white, and many marked with rose and red centers or edges. Pkt.. 8c.

HEDDEWIGI, Double (Double Japanese Pinks) (B). A fine mixture of colors, varying from the richest velvety crimson to the most delicate rose. Plst.. 10c.

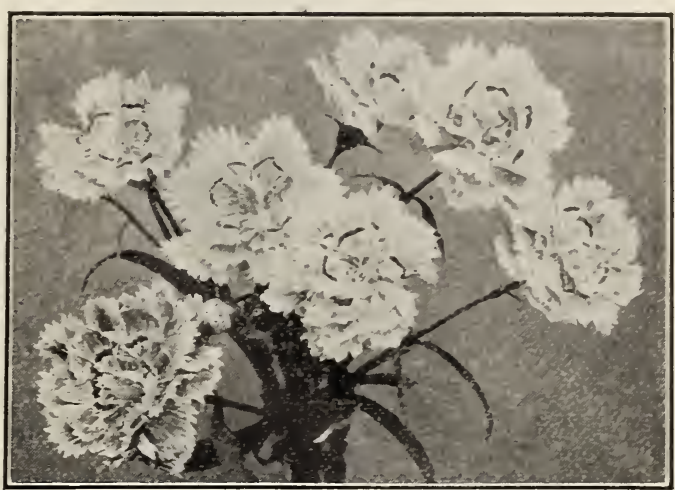

Double Dianthus Plumarius

LACINIATCS, Double Mixed (B). Flowers very large an ? double and the edges of the petals are exauisitely fringed and laciniated. A fine

IILUAISON (B). Very large double fringed flowers in very beautiful bright rose tints. Plit., 10c.

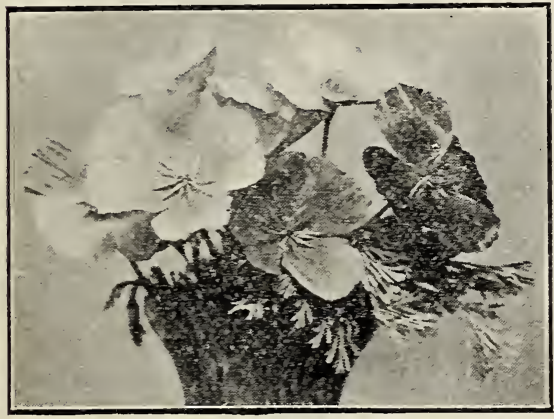

Eschscholtzia (California Poppy) SYOWBALL (B). Large, double, fringed flowers of pure white. Pkt., 10c. PLCMARIts, Double (P). The old favorite Clove or Hardy Garden Pouble and semi-double carnation-like flowers, in shades of rose, pink and white. Pkt., 10e. Plants, 3je each.

PLCMARITs, Single (Grass Pink. Scotch Pink. or Pheasant-Ere Pink) (P). A beautiful single hardy Pink. with fringed edged flotrers of various colors. Pkt., 8c. Plants, 25e each; 3 for $60 \mathrm{c} ; 12$ for $\$ 1 . i 5$.

DIMORPHOTHECA (African Daiss). Anrantica Hrbrids (A). Bushy plants, 12 to 15 inches high: flowers 216 inches and over across. Splendid mixture of all colors from white through various shades of cream, sellow, orange, rose, etc.. and many flowers being zoned with several of these colors around darker colored centers. Plit., 10c.

DRACOCEPHALUM, Moldaricum (Dragon's Head) (A). Showy ESCHSCHOLTZIA (California Poppy)

A beautiful and brilliant annual with finely cut. blue-green foliage. and glossy flowers of satin-like texture. One of the most desirable annuals for beds and borders and for cut flowers. Seed should be sown where the
plants are to remain. as they do not stand transplanting; require practiplants are to remain. as they do not stand transplanting; require practi-

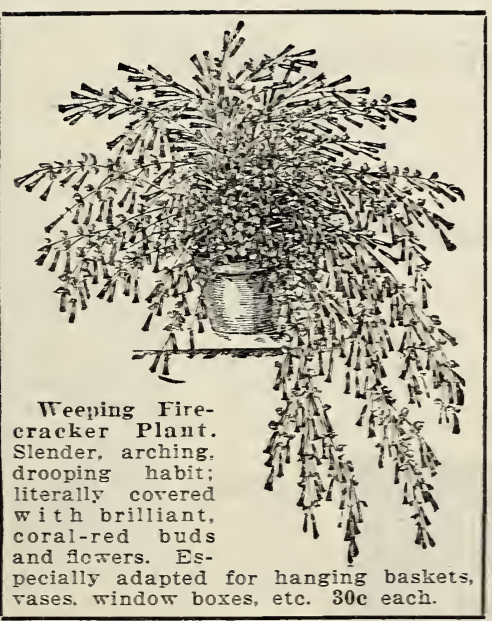

\section{FUCHSIAS}

pecially adapted for hanging basket,
rases. Window boxes, etc. $30 \mathrm{c}$ each.

BOSTON (H). A wonderfully healthy fern with long, drooping fronds whic often attain a leng
to 8 feet. $\mathbf{2 5}$ c each.

COMPACTA (H). The Ostrich Plume Fern. Fronds often over 8 inches wide. $40 \mathrm{c}$ each.

ROOSEVELT (H). Dense, massive fronds; erect in growth. Exceedingly graceful. $35 \mathrm{c}$ each.

MONS THIBACT. Rose vermilion. $30 \mathrm{c}$ each.

MoNstros. Pure white. Extra large flowers. $30 \mathrm{c}$ each. PHENoMENAL. Bright scarlet, with rich purple corolla. each.

PCRPLE PRITCE. Double. Sepals bright scarlet, corolla blue. 25̃e each.

SPECIOSA. Tube and sepals carmine. 25c each.

FUCHSIA SEED (H). A fine mixture of varieties. Plt., 25e.

FEVERFEW, Hardy (P). Free-flowering plants, producing all summer, fine double white flowers. Fine for cutting. Pkt., jc.

FOUR O'CLOCK (Marrel of Pera) (A). A well-known, handsome, free-flowering garden favorite; does well everywhere; 2 feet. Fine mixed colors. Pkt., 5c. bloom profusely over a long season.

CARMIIE FIIG (A). Deep carmine red. A bed of these in bloom appears like a mass of bright red Tulips. Pkt., 10c.

LARGE IELLOW (A). Large and beautiful. Plit., 5c.

ORANGE KITG (A). Rich golden orange. Pkt., 5̌c.

ROSEA (A). Beautiful rosy pink. Pkt., 10c. ROSE CARDIYAL (A). Dark rose on the outside; inside blush. Plit., 10c.

WHITE (A). Extra Fine. Pkt., 5c.

MIXED (A). A choice mixture of all colors. Plit., 8c.

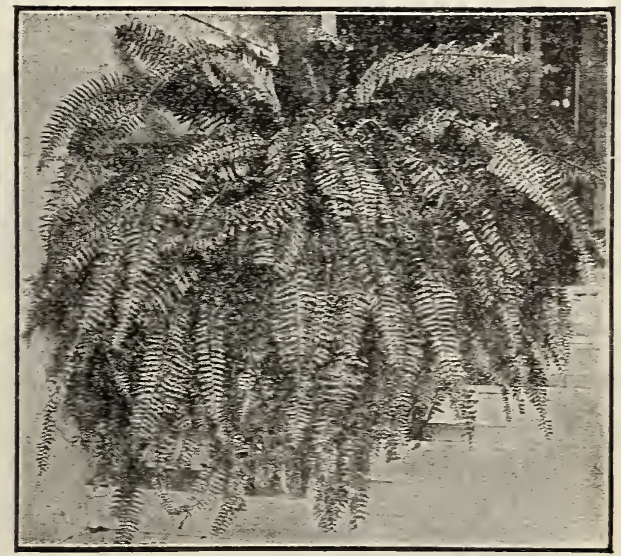




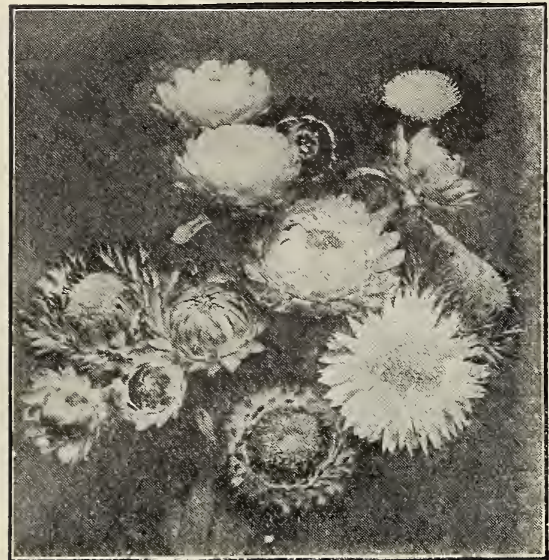

Helichrysum (Straw Flower)

\section{Everlasting Flowers}

To mect the growing demand for winter bouquets, we have added to our line several more valieties of Everlastings.

ACROLINUM (A). White and pink flowers, about an inch in diameter, and composed of many small fine petals. The texture of these petals is distinctly strawy to the touch, but of silky appearance. Plants 18 inches tall and covered with a mass of bright bloom. Pkt., 10c.

CHINESE LANTERN PLANT (P). See page 33 . Plit., 10c.

ERYNGIUM (Sea Holly), Planum (P). A pretty, bushy plant with thistle-like heads of flowers of a beautiful steel-blue Very useful for the winter bouquet. $2 \frac{1}{2}$ feet. Pkt., 10c.

EVERLASTING CELOSLA (A). See page 35. Pkt., 10c

EVERLASTING or STRAW FLOWER ASTER (A). See page 30. Pkt. 10c.

GILIA (A). Very graceful plant, about 2 feet high, with fine feathery foliage. Bear freely over a long season, globular heads about one inch across, of rich blue and white flowers, which last well when cut and retain their lovely color when dried. Pkt., 10c.

GLOBE AMARANTH (Gomphrena) (A). Popularly known as the Everlasting Bachelor's Button. Our mixture includes a fine range of colors, including white, shades of pink, lilac, and the rich bronzy-yellow tones deserve particular mention. Plants 2 feet tall, and are literally covered with buttonshaped flowers which measure nearly $\$ / 4$ inch in diameter. Pkt., 10c.

GYPSOPHILA, Paniculata (P). See page 41. Pkt., 10c. HELICHRYSUM (Straw Flower) (A). See page 42. Pkt., 10c.

LUNARIA (B). See description on page 44. Pkt., 10c. ORNAMENTAL GRASSES. See page 41. Plit., 10c.

RHODANTHE (A). A wealth of red, white and pink blossoms on graceful, slender stems. Its graceful habit makes it a particularly valuable addition to winter bou-

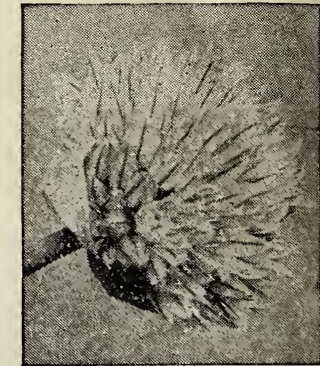

Globe Amaranth quets. Succeeds in a light rich soil and a warm sheltered situation; also valuable for pot culture. Plkt., 10c.

STATICE (Sea Pink) (A). See page 50. Pkt., 10c.

XERANTHEMCM (A). A charming Everlasting with flowers measuring 11/4 inches in diameter. The blooms come in white and various shades of pink, rose and red. The plants grow about 2 feet tall and bear a prốusion of blooms from July until frost. Easily dried for winter. Plit., 10c.

\section{Special Mixture of Everlastings}

This is a mixture of all the annual varieties of Everlastings listed in this catalog. Liberal size packet, $15 \mathbf{c}$; 2 pkts., $25 \mathbf{c}$.

\section{EVENING PRIMROSE (Oenothera)}

Elegant for a sunny position in the border or rockery, flowering freely the greater part of the summer.

LAMARCKIANA (A), Large flowered, yellow. Pkt., 10c.

ROSEA (P). Dwarf; carmine-rose. Pkt., 10c.

\section{GAILLARDIA (Blanket Flower)}

Annual. Remarkable for the profusion, size and brilliancy of their flowers, continuin in bloom from early summer until November. Excellent for beds, borders, or for cut ting. A fine range of colors, from creamy-white and yellow shades to orange and crimson, both single and double. A fine mixture. Pkt., бc.

Perennial. Among the showiest and most effective hardy perennial plants, and should find a place in every hardy border. They thrive in almost any position or soil, and practically take care of themselves. Large flowers of crimson and gold, on long stems; fine for cutting. Pkt., 8c. Plants, 25e each; 3 for 60c; 12 for $\$ 1.75$, postpaid.

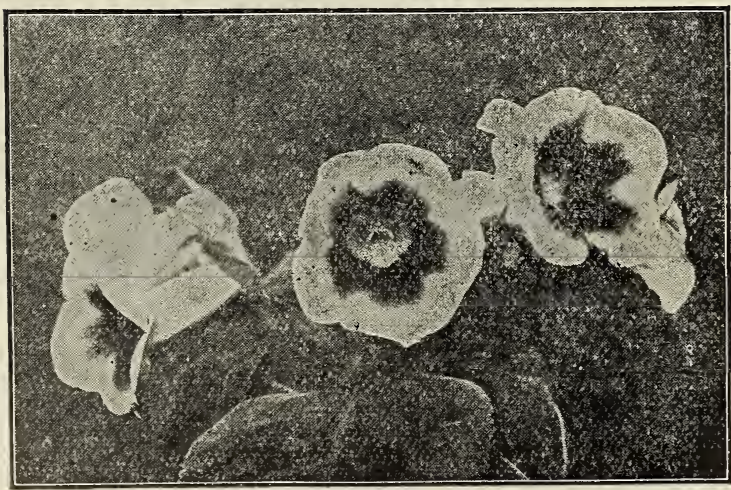

Gloxinia
GEUM Mrs. Bradshaw (P). Beautiful branching plant, about

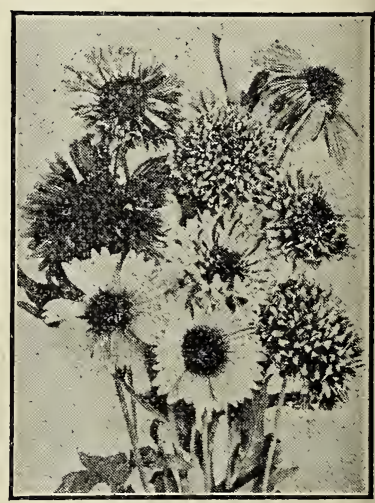

Annual Gaillardia 2 feet in height, bearing profusely throughout the entire summer, large showy, double flowers of brilliant orangescarlet. Excellent for cutting. Pkt., 10c.

\section{GLOXINIA}

HYBRIDA GRANDIFLORA ( $H)$. The finest strain of Gloxinia; magnificent flowers of the richest colors, containing the spotted hybrids as well as the finest self-colored sorts. Pkt., 25e. Bulbs which will bloom in 6 or 8 weeks from time they are planted, $40 \mathrm{c}$ each; 3 for $\$ 1.00$.

HARDY GLOXINIA (Incarvillea Delarari) (P). A showy plant for the hardy border, producing large gloxinia-like, rose colored flowers on 15 to 18 inch stems during June and July. Succeeds either in sun or shade, but should be protected with leaves or litter during the winter. Plants, 35c each; 3 for 90c; 12 for $\$ 3.00$. 


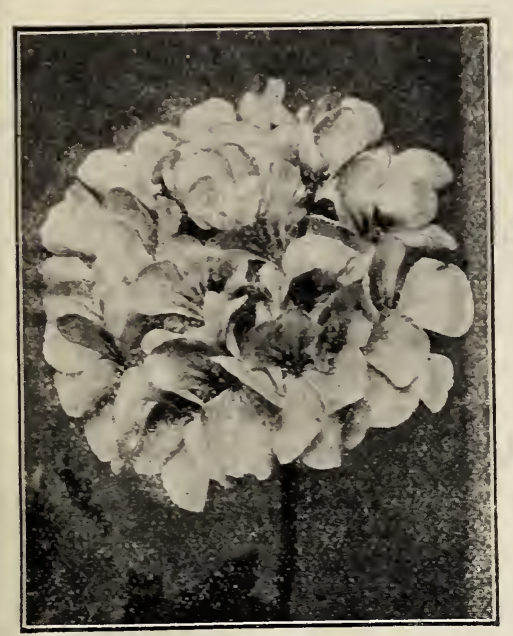

Geranum

\section{GERANIUMS}

S. A. NUTT. Darkest and richest Geranium grown. Dark, deep, rich, velety-maroon. 25c each. JEAX VIAD. Bright, rosy-pink with white blotch in the center. Dware and very free blooming. $25 \mathrm{c}$ each. RADIO RED). A new Geranium of a bright, dazzling scarlet. 30e each

ALPHONSE RICARD. Brilliant orange red; strong grower; dwart and branching. 25e each.

\section{Pansy Geraniums \\ (PELARGONITII)}

EASTER GREETINGS. Gorgeous in colorng; fiery amaranth red; some describe it as a brilliant rose. Plants in five-inch pots have produced $45 \mathrm{c}$ each.

\section{GERANIUM SEED}

A superb strain of the finest American and European varieties. Very interesting to grow pkts., 25c.

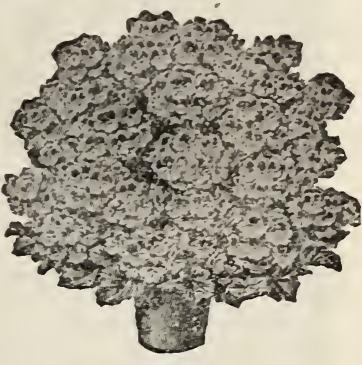

Pansy Geranium

\section{Ornamental Grasses}

TARIEGATED RIBBON GRASS (Phalaris Variegata) (P). Leaves longitudinally striped with white; very ornafor $\$ 1.00$, postpaid.

MINED ORNAMENTAL GRASSES (A). Most useful for winter bouquets when combined with Everlastings or straw Flowers. Easily grown in any soil. A nice mixture of the finest varieties. Plit., 10c.

\section{Ornamental Gourds}

(A) Calabash Pipe, Dipper, Dish Cloth, Nest Egg, PearShaped, Powderhorn, and Sugar Trough. Your choice of these varieties at 10c per packet; 7 packets-one of each variety-10c.

Mixed Varieties. A fine mixture of rare, useful and ornamental varieties. Pkt., 10c; 3 pkts., 25c.

GODETIA (A). Beautiful, hardy annual about one foot high; blooms profusely; showy flowers of satiny texture, not unlike an Azalea, in many rich and varied colors and

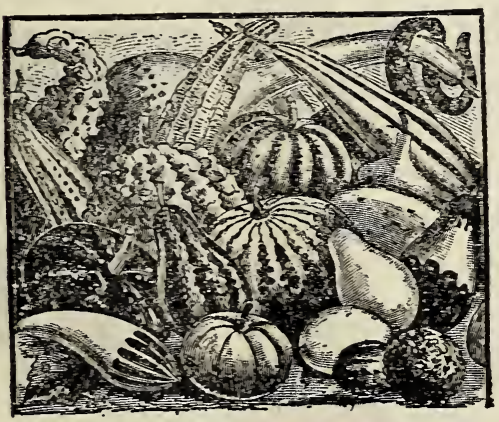

Ornamental Gourds 3 to 4 inches across.

\section{GYPSOPHILA (Baby's Breath)}

Elegans White (A). Pure white; extensively grown by florists for use with other cut flowers. Pkt., Jc.

Elegans Rosea (A). Soft pink; exceedingly beautiful. Pkt., je.

Paniculata (P). Very fine; superior to Asparagus STRAWBERRY GERANILII One of the most beautiful plants imaginable; a gem of many colors. The eaves are nearly round, and striped freely with silver bands; blooms white, of great beauty and borne in spikes nearly 12 inches high. The plant is of easiest growth; will stand neglect and mistreatment; adapted for h a nging baskets. vases, etc. $30 \mathrm{c}$ each Pan for mixing with other cut flowers. and used for winter bouquets. A most desirable addition to the hardy border. 10c. Plants, 30c each; 3 for $60 \mathrm{c} ; 12$ for $\$ 1.75$, postpaid.

\section{Giant Hyacinth}

Hracinthus Candican. A species of Hyacinth which blooms late in the sum-

mer, growing 3 to 5 feet high; spikes of pure white flowers 2 feet
Large blooming size bulbs. 20c each; 3 for 50c; 12 for $\$ 1.50$, postpaid.

\section{HIBISCUS}

AFRICANCs (A). Large, saucer-shaped, cream-colored blossoms, dark purple

center. 2 feet. Pkt., 8c. $(P)$. See inside back cover page of this catalog for Mrictices of plants. Pkt. 10c.

PEACHBLOW (H). Flowers are double; charming, rich, clear pink; an entirely PEACH most beautiful shade. A fine pot plant for house or porch. 30c each.

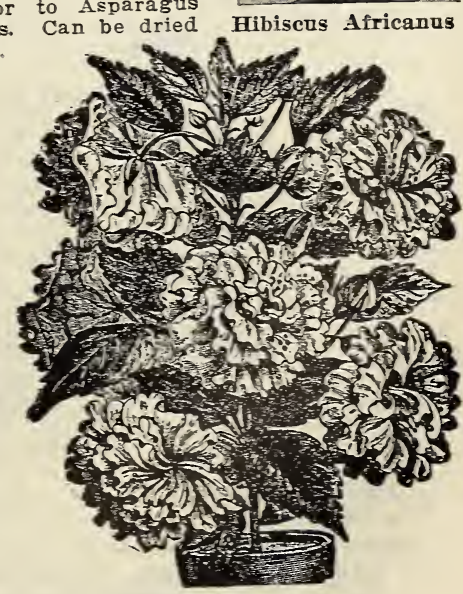

Hibiscus Peachblow 


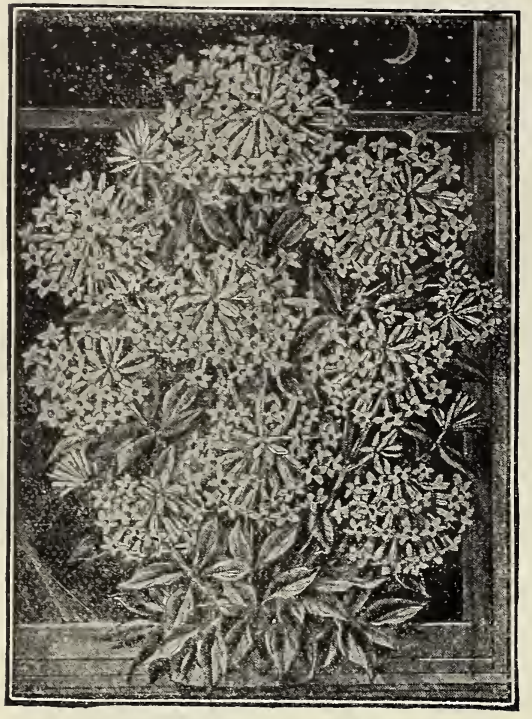

Night Blooming Jasmine

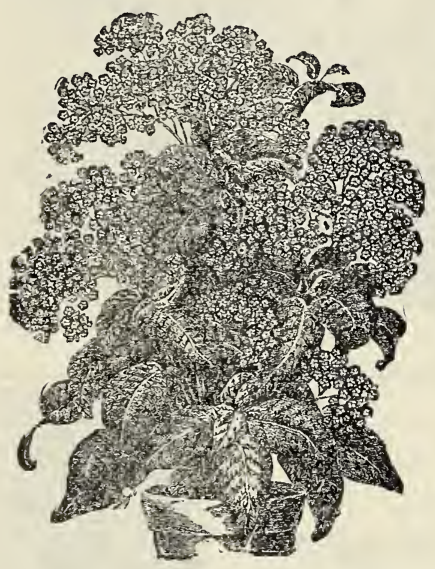

Giant Heliotrope Midnight

\section{Night Blooming Jasmine}

The Night Blooming Jasmine (Cestrum Parqui) is a highly prized house plant. The foliage is a deep green color; produces richly fragrant blooms; very fragrant at night. Plants, 35e each; 3 for \$1.00.

\section{HELIOTROPE}

These are universal favorites on account of their delightful fragrance. Flower equally well as bedding plants in summer or as pot plants during the winter.

SWEET SCENTED MIDIGHT. New giant-flowered, wonderful Heliotrope: darliest lavender-purple. 30c each.

HELIOTROPE SEED. Choice mixture of colors. Pkt., 10c.

\section{HELICHRYSUM (Straw Flower)}

Monstrosum (A). The largest of the Everlasting Beautiful Aster-shaped flowers that, when dried retain much of their original shape and splendor. Popular for winter decorations, for which purpose the blossoms should be cut when about one-third open, tied in small bunches, and dried slowly in a cool, shady place, hanging the flowers downward to keep the stems straight. We can supply seed in the following separate colors. Fire Red, Golden Yellow, Crimson-Purple, Rose-Pink, Salmon-Rose, White. Pkt., 10c; 6 pkts., (one of each color) 40c. All colors mixed: Pkt., 10e; 3 pkts., 25e.

\section{HOLLYHOCK}

One of the most majestic of hardy plants, and a clump or row of them in any garden gives an effect not attainable with any other plant. Unsurpassed for planting among shrubbery or forming a background for other flowers. Seed sown any time before midsummer will produce fine plants for flowering next season. We can supply seed from the finest double flowers in the following colors: Apple Blossom, Rose, Salmon-Rose, Deep Scarlet, Dark Crimson, Lilac, Purplish Violet, Dark Yellow, Pure White. Pkt.. 10c; 3 pkts., 25̃c; 9 pkts. (one of each color) 65̃c. All colors mixed: Pkt., 10c; 3 phts., 25̃c.

Allegheny (P). Enormous flowers; beautifully fringed petals. Colors vary from palest pink to deep red. Spikes 6 to 7 feet high. Pkt., 10c.

\section{HYDRANGEA}

\section{(FRENCH OR PORCH)}

These Hydrangeas are especially adapted for pot or tub plants for indoor, porch, lawn or garden decoration. In some soils the flowers turn blue, and this color can be secured artificially by mixing one-half pound of broken alum with each one-
half bushel of soil.

Bouquet Rose. Deep rose-amber, turning to bright red. 30c each.

La France. Delicate rose. Produces a wealth of bloom. 30e each.

Mme. Mouillere. Purest white with rosy carnine eye. 30c each.

\section{HYACINTH BEAN (Dolichos)}

Purple Soudan (A). A rapid growing climber for sunny situations. 8 to 10 feet. Stems purplish-red; red and purple shades in the leaves. Long spikes of pea-like flowers of deep reddish maroon, followed by beautiful metallic purple seed pods. Pkt., 5c.

Princess Helen (A). Pure white form of above; green foliage. Pkt., 5c.

White Bush (A). A bush form of Princess Helen. Magnificent flower spikes that grow from 10 to 15 inches above foliage. Pkt., 8 c.

ICE PLANT (A). Fine trailing plant for borders and hanging baskets, and valuable for dry, sunny situations on banks, rockwork, old walls, etc. Foliage very ornamental, being covered with ice-like globules. Pkt., 5c.

IMPATIENS, Everblooming (H). One of the most beautiful and free blooming bedding or house plants. They produce a great abundance of bright colored flowers which are well shown off by a background of heavy, rich foliage. Colors pink, orange-pink and brilliant vermilion. Continuous bloom may be expected from July to October. Plants, 30e each.

IRIS, Kaempferi (Japanese Iris) (P). Flowers 10 to 12 inches in diameter; gorgeous combination of colors. Bloom later in the season than the German Iris. Pkt., 10c.

IVY, Parlor (H). A strong growing, climbing vine with bright green foliage. Especially suitable for indoor hanging baskets, boxes, trellis work, etc. Plants, 20c each.

JAPANESE HOP (Humulus Japonicus), Variegated-Leaved (A). A rapid climber; one of the best plants for covering verandas, trellises. etc. The large handsome leaves are beautifully variegated, green and yellow, and make a dense covering. Pkt. 10c.

JAPANESE UMBRELLA PALM (H). Not a true palm, but handsome ornamental palm-like plant. Grows in water or soil. Indispensable for aquariums, fountains or pools. Pkt., 10c. Plants, 25̃c each.

JOB'S TEARS (A). Curious and ornamental. Seeds used for beads and ornamental purposes. Pkt., 5̃c; oz., 15e.

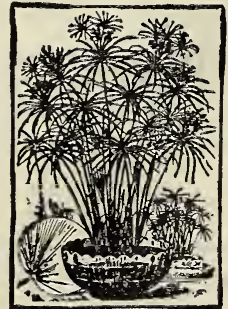

Umbrella Palm

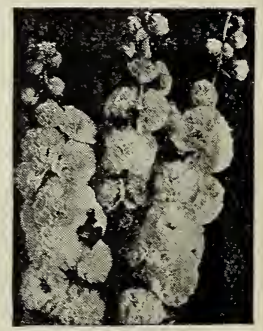

Double Hollyhock

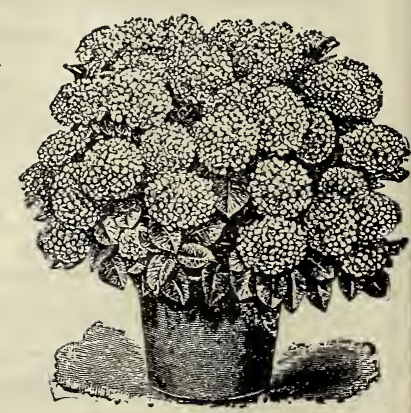

French Hydrangea 


\section{Jerusalem Cherry}

A very showy house plant, loaded with ornamental "cherries." which turn to glossy scarlet when ripe. Fine for Thanksgiving and Christmas decoration. The bright cherries, which are not ellible, will hang on the plant all winter foliage always green and very cruamental. Pkt.. 10c; 3 pkts., 25c. Plants, 40c each.

KOCHIA (Mexiean Fire Plant or Burning Bush) (A). This beautiful bush grows about 2 to $2^{1}$ feet in heiglit and resenibles a closely trimmed ornamental evergreen. May be grown singly or in the form of a hed
early fall the entire bush turns bright scarlet. Pkt., 10c.

LARKSPUR, Double Giant Hracinth-Flowered (A). The finest of all the annual Larkspurs: begin blooming early in. July and give a continuous succession of flowers from then until frost, a record that is not surpassed by any other annual. Their free, graceful habit and bright colors make them very popular for beds, borders, and for cutting. A fine assortment of pink, lilac, flesh, white, dark rose and blue shades, 3 feet. Pkt., 10c.

All Sorts Mixed. Many different strains, kinds, colors and shades. Pkt., 5c.

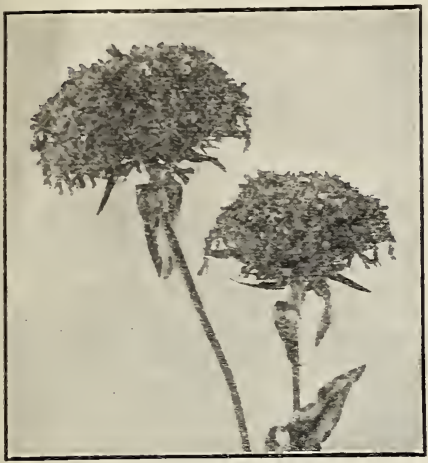

Lrchnis

\section{Lantanas}

The unexcelled ererblooming bedding or burder plant; also used as pot plant, in hanging baskets, porch boxes and vases. Almost constant blooming. MICHAEL SCHMIDT. Brilliant yellow, passing o pure vermilion. 25c each; 3 for $; 0 \mathrm{c}$

ACRORA. Clear pink. 30c each; 3 for $85 \mathrm{c}$.

ALBA PERFECTA. Pure white; compact habit. 5e each; 3 for $70 \mathrm{c}$.

TETHYS. New beautiful lemon yellow. $30 \mathrm{c}$ each; 3 for $85 \mathrm{c}$.

RADIATION. Crimson changing to yellow at center. $25 \mathrm{c}$ each; 3 for $70 \mathrm{c}$.

WEEPING LANTAYA (Russelia Elegantissima) (H) A very striking semi-trailing plant, especially adapted for hanging baskets, vases, window boxes, etc. Large clusters of lilac or rosy-pink flowers. Exceedingly beautiful. 2Jc each.

LANTANA SEED, Ererblooming Hrbrids (H). One of the most desirable half-hardy perennial house or bedding plants. Terbena-like heads of orange, white. rose, crimsun and various red shades; constantly in bloom. 2 to 3 feet. Fine mixture of colors. Pkt., 10c. LOBELIA, sapphire (H). A beautiful trailing plant of strong growth; a mass of unusually large sapphire-blue flowers with a beautiful white eye; never out of flower. A most desirable pot and basket plant. Plants, 25c each; 3 for 60 c.

Hybrids (H). Delicate blue and white flowers. Pht., 8c.

LYCHNIS, Chalcedonica (Rose Champion or Jerusalem Cross) (P). Handsome hardy perennial plant of easy culture, for massing in beds and borders; 2 feet. Brilliant scarlet flowers; suitable for cutting. Pkt., 8c. Plants, 2je each; 3 for $60 \mathrm{c} ; 12$ for $\$ 1.50$, postpaid.

\section{Lathyrus (Perennial Sweet Peas)}

Showy, hardy climbers that remain in the ground rear after year; often $\delta$ to 10 feet in height and bearing a mass of flwers throughout the summer. Fine for covering old stumps, fences, etc., and excellent for cutting. Mixed colors. Pkt., 10c. Plants, $30 \mathrm{c}$ each; 3 for $70 \mathrm{c} ; 12$ for $\$ 2.00$, postpaid.

\section{Lily of the Valley}

These popular and fragrant flowers do their best in a shady situatiun. A hardy perennial that is too well known to require description. $20 \mathrm{c}$ each; 3 for $40 \mathrm{c}$; 6 for $60 \mathrm{c}$; 12 for $\$ 1.00$.

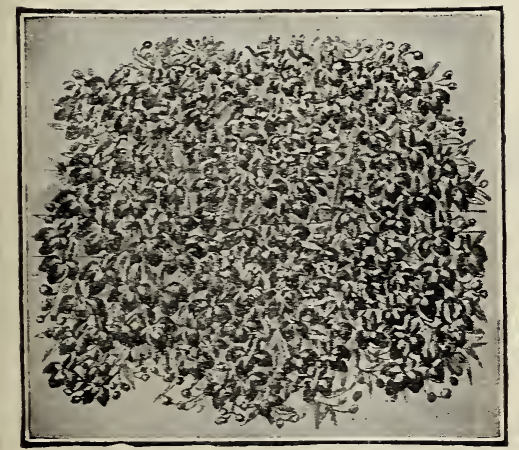

Lobelia Sapphire

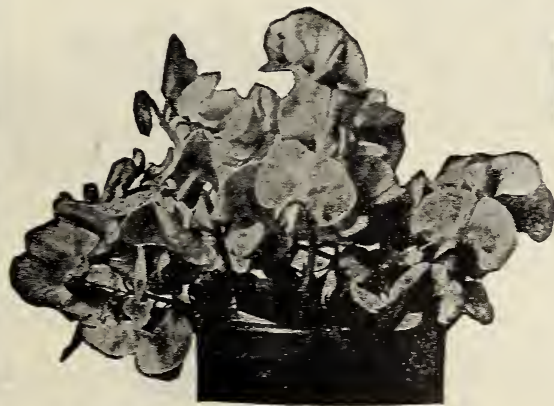

Lathyrus (Perennial Sweet Peas)

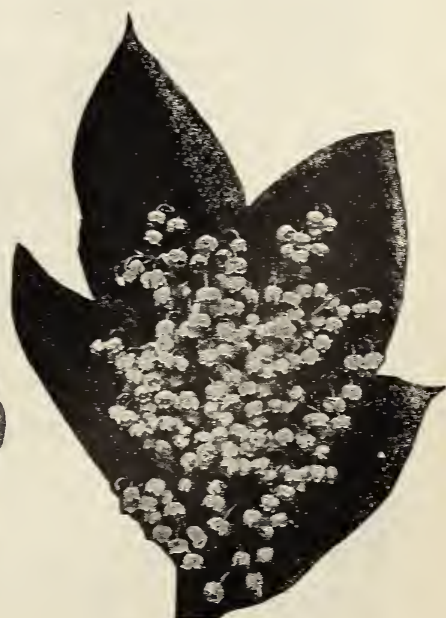

Lily of the Talley 


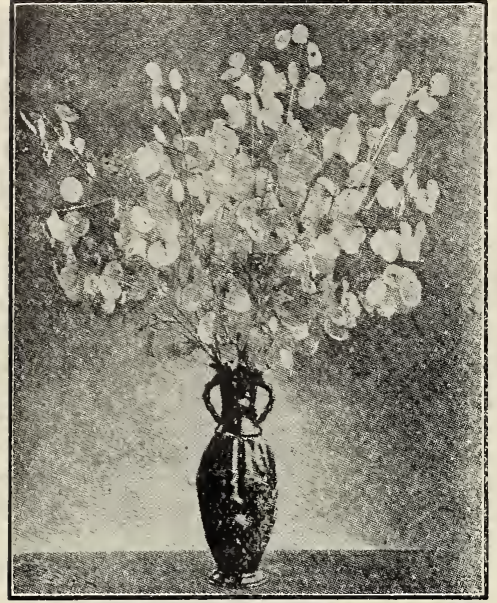

Lunaria

\section{Lunaria, or Honesty}

\section{(CHINESE MONEY PLANT)}

A beautiful hardy biennial, about 2 feet in height, which is known in the different provinces of China as the silver, satin or money plant, and in Europe as St. Peter's Penny. Flowers are violet-purple, white and dark rrimson, followed by the silvery seed pods, which present a beautiful and rather curious appearance. When dried, the stems which are loaded with these glistening seed pouches, will last indefinitely and are exquisite for winter bouquets and other decorative purposes. Pkt., 10e; 3 pkts., 25e.

LUPINUS, Annual Mixed (A). Free-flowering, easily grown annuals, with long graceful spikes of rich blue, rose and white pea-shaped flowers; valuable for mixed borders, beds, and for cutting; prefer a little shade. 2 feet. Plit., 5e.

Perennial (Polyphyllus) (P). Long graceful spikes, 3 feet high, which are loaded with pea-shaped flowers. Fine for perennial beds and backgrounds and excellent for cut fowers. Can supply in Blue, Rose, White and Mixed Colors at 10e per packet; 3 pkts., 25e.

LINUM, Grandiflorum Rubrum (Crimson Flax) (A). One of the most ef fective and showy.bedding plants, having fine foliage and delicate stems, with brilliant scarlet-crimson flowers. 1 foot. Pkt., 5e.

Perennial Blue (P). Bright blue flowers; hardy; 18 inches. Pkt., 5c.

MALVA (Musk Mallow), Moschata Rosea (P). A branching bush about 2 feet high covered throughout the summer with beautiful delicate pink flowers, $1 \frac{1 / 2}{2}$ inches in diameter. Very useful for cutting. Plit., 8c.

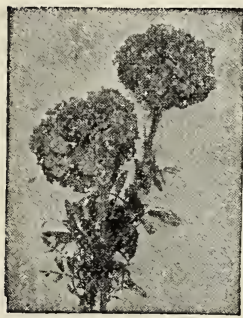

G. Af. D. Marigold

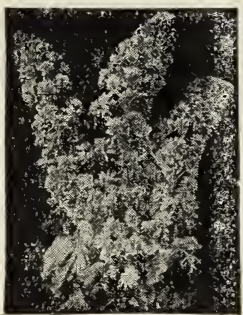

Mignonette

Moschata Alba (P). A white variety. Pkt., 8c.

MARIGOLD, Double Dwarf French (A). Few annuals are as effective or flower for so long a period; unsurpassed for borders or beds. 10 to 12 inches. A fine mixture of lemon-yellow, goldenyellow and rich, mahogany-brown shades. Pkt., 5c.

Giant African Double (A). Immensely large, double quilled and imbricated flowers in all shades of yellow. Pkt., 5c.

Legion of Honor (A). A single flowering Marigold, forming bushes 9 inches high. Begin flowering in June, continuing until frost. Golden yellow, with large spot of velvety crimson at the base of each petal. Pkt., 5c.

MATTHIOLA, Bicornis (Evening Scented Stock) (A). The flowers of lilac color, appear in the morning, evening and after showers, and emit a delicious perfume perceptible at a considerable distance. Pkt., ōc.

MIGNONETTE, Sweet (A). The old variety with small spikes, but very sweetly scented. Pkt., 5c.

Superb Mixed (A). Many shades and types; very choice. Sowings made in April and again in July will keep up a succession of bloom from early summer until frost; can also be grown in pots for winter and early spring flowering. Pkt., 10c.

\section{MYOSOTIS (Forget-Me-Not)}

Few spring flowers are more admired than the lovely Forget-MeNots, which are especially effective when grown in masses. The alpestris varieties are blennial and come into bloom very early in the spring and are largely used for bedding or borders in connection with spring-flowering bulbs, Pansies, etc. They also bloom again in the fall; bloom freely the first season and still more profusely the second spring. They do best in shady, moist situations.

Alpestris, Blue (B). Dwarf bushes of trailing habit. A mass of light blue flowers which stand out sharply from the rich green foliage. Pkt., 10e.

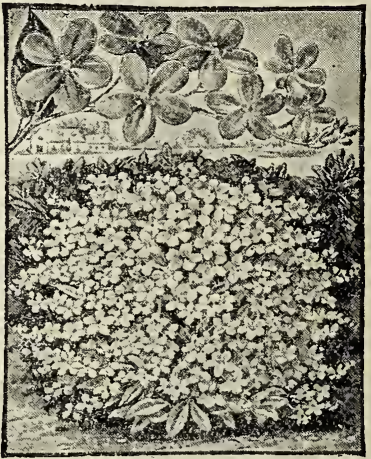

Irvosotis (Forget-Me-Not)

Alpestris, Rose (B). Beautiful rose-pink; a color rather rare among Forget-Me-Nots. Pkt., 10c.

Palustris Semperflorens (Perpetual Flowering) (P). This lovely perennial Forget-Me-Not is of everblooming type. Flowers of lovely bright sky-blue color: begin to flower about a month later in the spring than the biennial varieties and continue blooming until late autumn. Pkt., 15c. Plants, 30e each; 3 for 70c; 12 for $\$ 2.00$, postpaid.

\section{MOONFLOWER}

Sweet Scented Giant Flowered (A). A rapid climber, reaching a height of 20 to 30 feet; foliage very dense. Every evening and on cloudy days the vines are covered with immense flowers of delicate coloring, manys 25̃c.

\section{Blue Lily of the Nile}

A splendid ornamental plant with bright evergreen foliage spreading 3 or 4 feet and surmounted with spikes of bright blue flowers which remain in bloom for a long period. It is a most desirable tub plant for porch or lawn. Should be wintered in the cellar or greenhouse. Plants, 30c each; 3 for 85 c, postpaid.

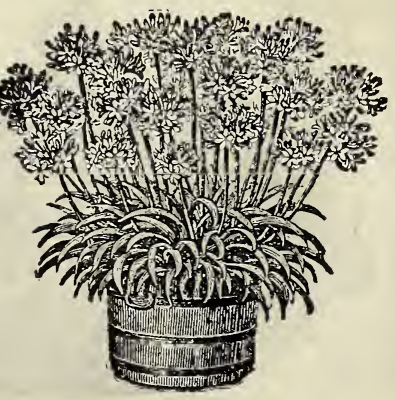

Blue Lily of the Nile

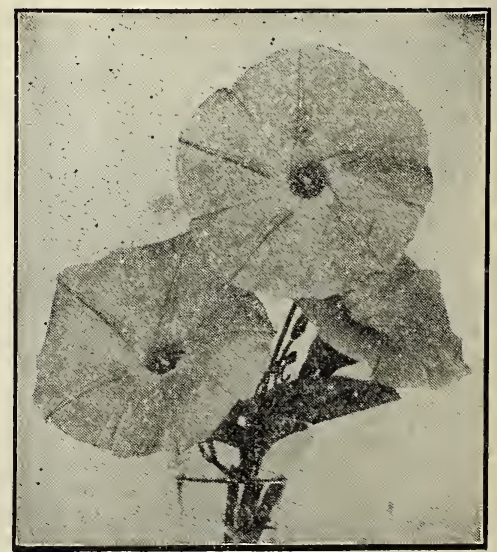

Moonflower 


\section{Nasturtiums}

\section{DWARF SORTS}

For ease of culture and duration of bloom. brilliancy of coloring and general excellence, nothing excels Nasturtiums. All they need is moderately good soil in well-drained. sunny position, and from within a few weeks after seed is sown until hard frost comes there is an endless profusion of their Eorgeous blossoms.

ACROR. Bright chrome-vellow flowers attractively veined with purplisin carmine. The color contrast is particularly striking. Rich, deep green foliage.

CLOTH OF GOLD. Brilliant scarlet flowers on long stems; bright golden yellow foliage.

DWARF VESTTILs. Immense blooms of exquisite salmon-rose, beautifully marked with salmon-orange veins; dark green foliage.

EMPRESS OF LIDLA. Pich sa'mon-scarlet; deep purplish green leaves GOLDEN KIVG. Glowing orang:-yellow; dark purplish green foliage. GOLDEY IIDNIGHT. Rich dark red blooms; light golden yellow foliage.

PRICES-Four choice of abore six varieties at 5c per packet; 20c per oz.; six packets (your choice of varieties or one of each), 25je.

\section{DWARF SORTS IN MIXTURE}

DWARF GOLDEN-LEATED VARIETIES. A splendid mixture of many golden-leaved sorts; blossoms of all colors. Fine for borders. Pist., 8c; oz., 25c.

DWARF IVY-LEAVED. Flowers well up above the foliage, and beautifully fringed at edges. Blossom in greater profusion than any other variety of Nasturtium and remarkable for their colors and color com. binations not found in anj other strains; foliage havin

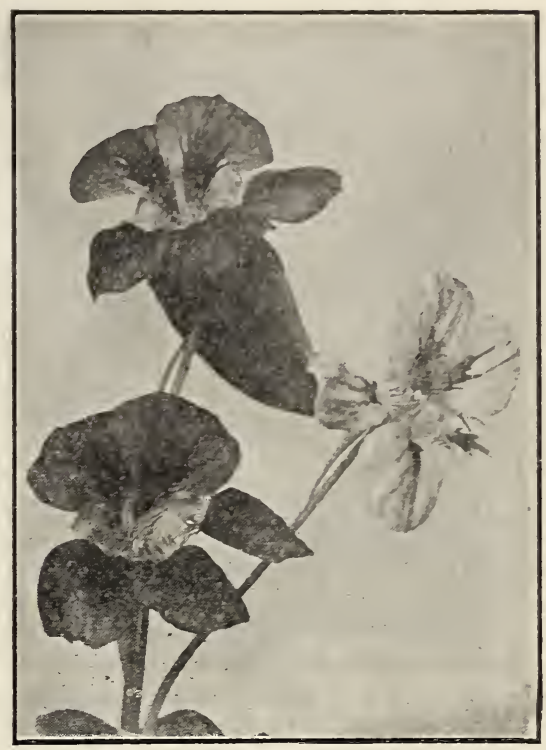

Dwarf Nasturtiums $8 \mathrm{c} ;$ oz., $25 \mathrm{c}$.

DIIARF TIRIEGATED LEIVED. Handsome foliage plant with flowers of many bright colors. Each leaf is in a differen: degree beautifully marked with yellow, white and green, so that the plants would be worthy of culture almost for the foliage alone. Ters showy and biooms freely and continuously. Plit., 8c; oz., 25c.

DWARF MIXED. A fine mixture of all colors and kinds; rellow, rose, crimson, scarlet, brown. spotted, striped and splashed. Pkt., 5̃c; oz., 15c; 1. 1b., $10 \mathrm{c}$.

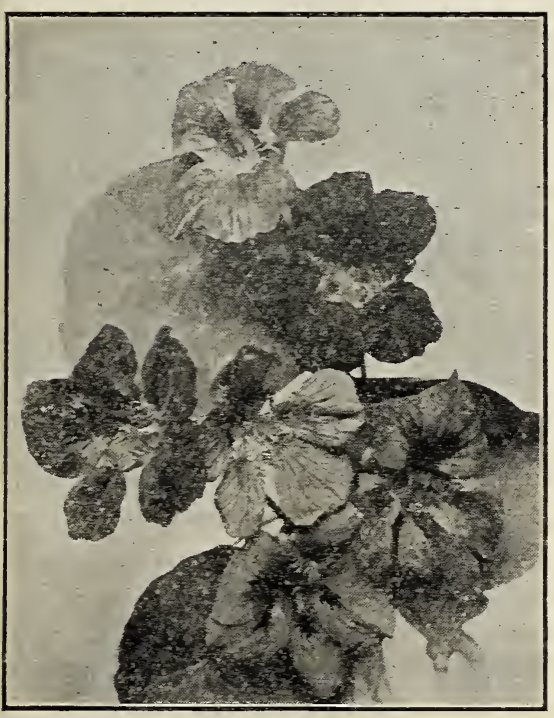

Tall Nasturtiums

\section{TALL SORTS}

BCTTERFLY. Light lemon-rellow. attractivels marked on the three lower petals with a blotch of rich terra cotta red; the two upper petals marked in shades of bright red: large flowers and long stems.

DUNXETT'S ORANGE. Rich deep orange with deep crimson blotches. EDUARD OTTO. Brownish lilac.

FORDHOOK FASHION. Bright cherry-rose, overlaid with deep veinings of old rose: biossoms of exceptional size; deep blue-green foliage. MTDIGHT. Deep brownish red, of soft relvety texture, resembling polished mahogany; rich deep green foliage.

TALL VESUVIC. Salmon-rose with salmon orange veins; dark green foliage.

PRICES-Your choice of abore six varieties at je per packet; $20 \mathrm{c}$ per oz.; six packets (your choice of varieties or one of each), 25 c.

\section{TALL SORTS IN MIXTURE}

TILI IVY-LEAVED, Fine fringed petals; colors intense and rery striking; iry-like foliage and rines exceedingly graceful. Pkt., 8c; oz., 25c.

TALL VARIEGATED-LEAVED. Light green foliage, beautifully marbled and blotched with white. Makes a striking vine with its bright blossoms of many colors. Pkt., 8c; oz., 25c.

TALL MIXED. Our special mixture contains all the choicest colors and many kinds and types of Tall Nasturtiums. Pht., 5c; oz., 12c; $1 / 4$ lb., 35c.

\section{MORNING GLORY}

Double Mixed (A). Double and semi-double flowers. Plt., 8c.

Dwarf (A). Valuable for beds and borders; also as a winter-blooming house plant. 10 to 12 inches tall. Will thrive anywhere as long as they get plenty of sunshine. A fine mixture of colors. Pkt., 5c.

Brazilian (A). Pich. rose-colored blooms 3 inches across: very showy and free blooming. As a quick growing vine it has no equal, corering an enormous space in a short time. Pkt., 10c; 3 pkts., 25c.

Japanese Giants (A). This is a particularly attractive variety with large, deepls lobed leaves. The flowers are much larger than ordinary Morning Glories. The colors run from snow white through all possible shades of blue and rea, from palest pink to darkest reds and purples, and streaked, mottled and bordered in wonderful fashion. Pkt., 8c.

Japanese Extra Large (A). A superior strain of Japanese Giants; extraordinary fine colors and gigantic in size, measuring 6 inches across. Pkt., 15c; 2 pkts., 25c.

Japanese Fancr Fringed (A). A choice strain of Japanese Morning Glories with fringed and ruffled flowers. Pkt., $10 \mathrm{c} ; 3$ pkts., $25 \mathrm{c}$.

Superb Mixed (A). All the plain colors, variegated, mottled and striped. This mixture contains none of the abore varieties, but is a fine mixture of the old-fashioned sorts. Very hardy, so can be planted earlier and will begin to bloom earlier than the Japanese varieties. Pkt., 5c; oz., $15 \mathrm{c}$.

NICOTIANA, Affinis Hrbrids (Taberous-Flowered Tobacco). (A). Compact bush, about 3 feet high; blooms all summer and fall; delightfully sweet-scented, tube-shaped white, purple, red, salmon, pink and violet flowers. Fine mixture. Pkt., 8c.

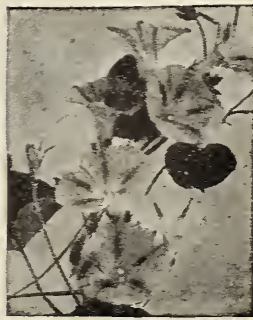

Morning Glory 


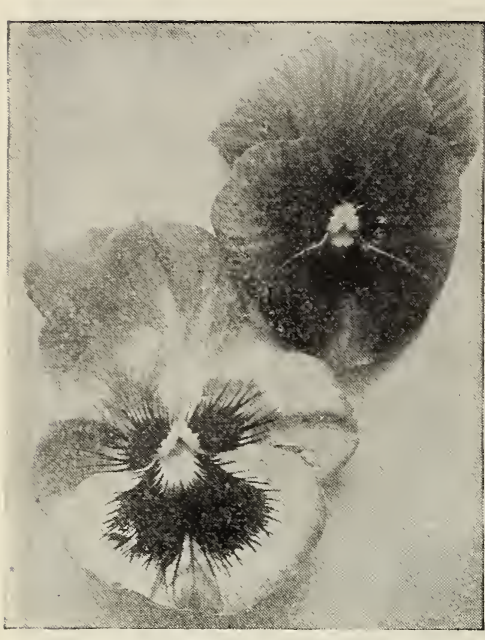

Giant Flowered Pansies

\section{Burgess' Choice Pansies}

Pansies are favorites with all, and are too well known to require any description. For best results you must start with a good strain. We spare neither pains nor expense to satisfy the most critical trade. Our seed is produced and saved with great care and is the best. The finest Pansies are, as a rule, shy seeders, which accounts for the difference in the price of the various mixtures.

BURGESS' BEST GIANT FLOWFRED. The largest and most beautiful of all. The finest collection of colors and variations of colors, with the gigantic blossoms well above the foliage, erect on long, stiff stems. Without an exception, the finest mixture ever offered, both as regards size and coloring; none better at any price. Plit., 25c; 3 pkts., 65c.

GIANT RTFFLED MASTERPIECE. Giant-sized flowers of most striking character, each petal being conspicuously curled or waved, giving them the effect of a double flower. The colors are mainly rich dark shades, bordered, blotched, or marked in ray-like veinings with contrasting colors. Bloom freely and continuously as long as the weather remains cool. Plkt., 20c; 3 pkts., 50e.

MAMMOTH ORCHID-FLOWERED. This distinct and beautiful strain of Pansies will appeal to those who prefer delicate tints and soft shades and colors. The unique colorings include shades of chamois, terra cotta, pink, lilac, rose and orange. The flowers are of good size and they bloom freely from early spring until late in the fall. The name "Orchid-Flowered" has been given them because of their delicate shades and finely ruffled edges. Pkt., 15c: 3 pkts., $40 \mathrm{c}$.

EXTRA FANCY LARGE FTOWERED. A fine mixture, similar to Burgess' Best Giant Flowered, but blossoms not quite as large. Pkt., 15c; 2 pkts., 25c.

CHOICE MIXED. A fine mixture of the ordinary varieties. Pkt., 8c.

PANSY PLANTS Our Pansy plants comprise a marvelous number of new shades and varieties as well as imcurled, ruffled and blotched. 6 for $40 \mathbf{4 0}$; per doz., r0c, post paid.

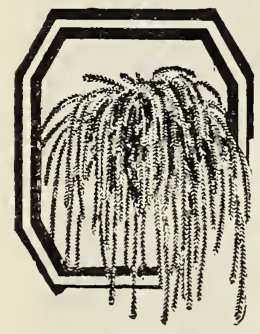

Parrot's Feather

\section{Maderia Vine, or Mignonette Vine}

A popular climber with thick, waxy, green, heart-shaped leaves, and numerous racemes of feathery white flowers of delicious fragrance. Grown from tubers, which may be taken up in the fall and stored like potatoes. Easily grown; will thrive in any soil or location; and will grow rapidly, covering a large space in a short time. One of the best vines for planting thickly along the front edge of a porch or window for quick effect. Tubers, 15c each; 3 for $35 \mathrm{c} ; 12$ for $\$ 1.00 ; 25$ for $\$ 1.75$, postpaid.

NIGELLA, Damascena (Love-in-a-Mist) (A). One of the prettiest annuals; finely cut foliage; blue and white flowers; fine for cutting; of easy culture, growing in any garden soil. $1 \frac{1 / 2}{2}$ feet. Pkt., 5c.

OLEANDER. No plant makes more handsome specimens for tub, pot or box culture for the house, veranda or yard. Large. double, pink blossoms, as pretty and as fragrant as a rose. During the winter, the plant should be stored th a light cellar oint. 35c each; 3 for 90c, postpaid.

OXALIS, Tropaeloides (A). An excellent little plant for edging or pots; blooms all summer in the greatest profusion; yellow flowers, rich brown foliage. Pkt., 10c.

ORNAMENTAL COTTON (A). Many people in the North have never seen cotton growing. As it is by far a mure beautiful plant than many of the ornamentals and can be successfully grown in the North for ornamental purposes, it makes a very desirable addition to any flower garden.

\section{Oxalis Bulbs}

\section{Fine for borders, pot} culture, hanging baskets, green foliage; white, pink and red blossoms, your choice of colors. 5e each; 25̃c per dozen; $\$ \mathbf{1 . 5 0}$ per 100 , postpaid. vases, etc. Beautiful

large, showy flowers, followed by large fluffy balls of white cotton. Pkt., 10c; 3 pkts., 20c.

PHILIPPINE COPPER PLANT (Acalypha Tricolor) (H). A most distinctive and valuable bedding or pot plant. Large, beautiful, coppercolored foliage, with blotches of crimson-bronze. Highly tri-colored and of tropical appearance. Easily grown. Plants 30c each; 3 for 85c, postpaid.

\section{Portulaca}

Giant Flowered Mixed (A). One of the showiest low annuals, of easy culture, thriving best in light loam or sandy soil and in a sunny situation. Fine for massing in beds, edgings or rock-work, and frequently used to sow broadcast over sunny banks, etc. 6 inches. Flowers of the richest colors. Pkt., 5c.

Double Rose Flowered (A). Unsurpassed for brilliancy and beauty. Seed saved from perfect double flowers, so will produce a large percentage of double blossoms. All colors mixed. Pkt., 10c.

\section{PARROT'S FEATHER}

\section{Beautiful House Plant}

The Parrot's Feather is a handsome, drooping. fern-like water plant, with delicate feathery foliage. An ideal plant for hanging baskets, wall vases, jardinieres, window boxes, water tight vessels and aquariums. Grows rapidly in the house in either soil or water. It requires very little care or attention and thrives when other plants fail. Nothing more interesting or attractive as a table or window plant, and is admired by everyone. 25c each; 3 for $50 \mathrm{c} ; 7$ for $\$ \mathbf{1 . 0 0}$, postpaid,

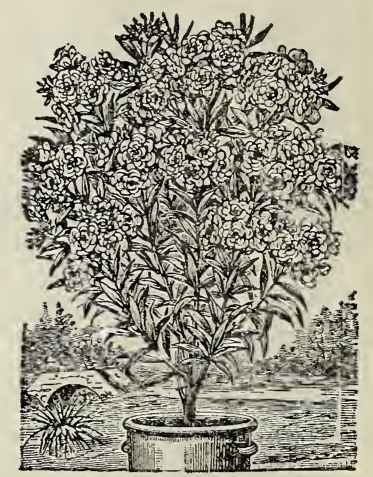

Oleander

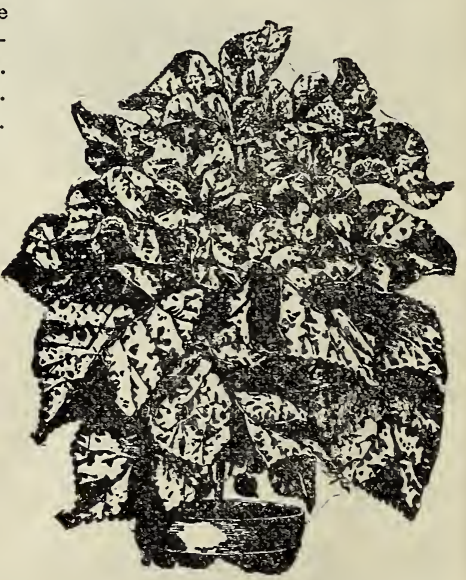

Philippine Copper Plant 


\section{Burgess' Choice Petunias}

For outdoor decoration, porch or window boxes, few plants equal the Petunia in effectiveness. They commence flowering early and continue a sheet of bloom until lilled by frost.

\section{Giant Flowering Varieties}

GIANT FLOWERED HYBIIDS. A wonderful assortment of colors; mammoth in size; single. Plit 15e.

GIANT FRINGED. Flowers of extraordinary size, deeply fluted, ruffled and fringed; varied and brilliant colors. Pkt., 20c.

DOCBLE GINT FIINGED. An excellent, carefully hand-pollenized strain yielding a large percentage of plants having double, finely fringed flowers. Enbracing a splendid variety of colors and many beautiful combinations. Seed in mixture of colors only. Small pkt., 35c; 3 pkts., s1.co. Plants, in separate colors-purple, white, magenta, pink and variegated-at $30 \mathrm{e}$ each; 3 for $85 \mathrm{c}$; or 5 for $\$ \mathbf{1 . 3 5}$.

TRIUMPH OF THE GIANTS. The largest and finest single Petunia. Fwers often meisure 7 inches across. A variety of gorgeous colors and markings that is unsurpassed. Pkt., 25c.

\section{Balcony Petunias}

A most valuable type of Petunias for porch boxes, hanging baskets, beis, terraces, or among rockwork. Individual blossoms measure 3

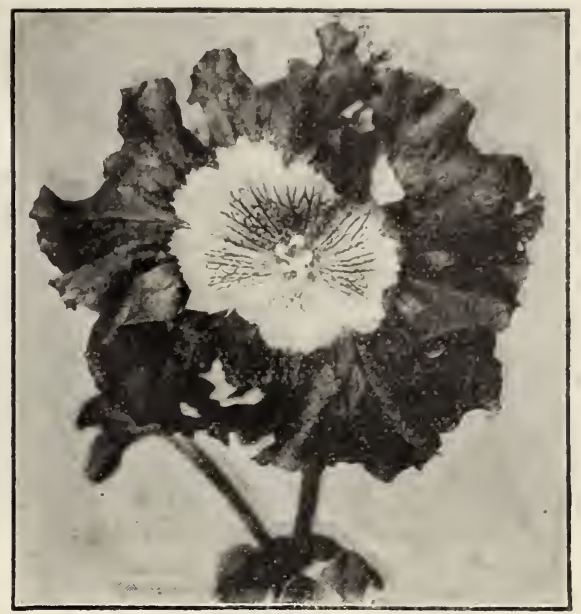

Petunia Triumph of the Giants

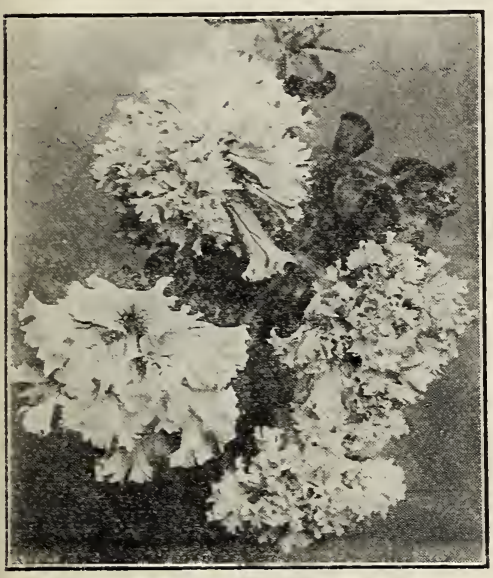

Double Giant Fringed Petunia inches in diameter and
throughout the season.

Balcony, Purple. Rich velvety purple.

Balcony, Rose. Brilliant rose-pink.

Balcons, White. Pure white.

Balcony, Mixed. A mixture of the above colors.

Seed of any of the above Balcony Petunias, 15c per pkt.; 2 pkts., 25c; 3 pkts., 35c.

\section{Single Bedding Petunias}

Conntess of Ellesmere. Pose with white throat. Pkt., 10c.

General Dodds. Velvety blood red. Pkt., 10c.

Howard Star. Attractively marked with a five-pointed white star on purplish crimson ground. Pkt., 10c. GOOD MXED. A splendid mixture single bedding varieties. Pht., 10c.

\section{Phlox Drummondi (Annual Phlox)}

The annual Phlox is one of the most brilliant and one of the easiest and most satisfactory plants which can readily be grown from seed. It will grow and thrive in any kind of soil if given a sunny position. In a few weeks after the seed is sown the plants are a sheet of bloom, remaining so until frost. They show to best advantage when grown in masses, beds or borders; excellent for cut flowers.

The following colors are of the finest type, having the largest heads of blooms as well as the largest individual flowers, of strong, sturdy growth, attaining a height of about 15 inches.

Brilliant Scarlet. Pkt., 8c.

Deep Rose. Plit., 8c.

Yellow. Pkt., 8c.

Violet-Blue. Pkt., 8c.

White. Pht., 8c.

LARGE-FLOWERIIG IIXXED (A). All of the above colors as well as a great many others. Pkt., 8c.

STAR PHLOX (A). The flowers are either starred or fantastically fringed. A novel variety; many bright shades: mixed colors. Pht.. 10c.

\section{Hardy Perennial Phlox}

Our new improved Perennial Phlox are revelations of beauty, with enormous sized flowers, and absolutely hardy everywhere. The long blooming period from July to October, and the bright, showy colors make them indispensable for landscape work, massing, and cutting. We can supply fine plants in the following
separate colors: Crimson, Bright Pink, Salmon-Pink, Purple, Scarlet, White. 30c each; 3 for 60e; 12 for \$1.75. postpaid.

EVERBLOOMING HARDY PHLOX, Miss Lingard (P). This grand variety starts blooming much earlier than the above described sorts and continues to flower until late in October. Handsome, long spikes of white flowers with lavender-pink eye. Height about 2 feet. Admirably adapted for the flower garden and for cemetery planting. 35c each; 3 for $70 \mathrm{c} ; 12$ for $\$ 2.00$, postpaid.

PERENNIAL PHLOX SEED A select mixture of all colors. Pkt., 15c; 2 pkts., 25c.

\section{Giant Fan-Leaved Palm}

Beautiful in all stages of growth. Leaves large, fan-shaped and of cheerful green color. Plant of hardy constitution and adapted to all decorative purposes. 50c each, postpaid.

\section{Plume Poppy}

The Plume Poppy (Bocconia Cordata) is a stately hardy perennial 5 to 6 feet high, bearing panicles of creamy-white flowers, on spikes 2 to 3 feet long. Handsome for shrụbery border or masșing. Pkt., 10c. Plants, 30c each; 4 for $\$ 1.00$, postpaid.

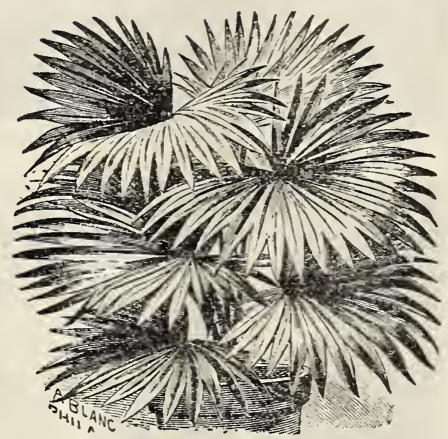

Giant Fan-Leared Palm

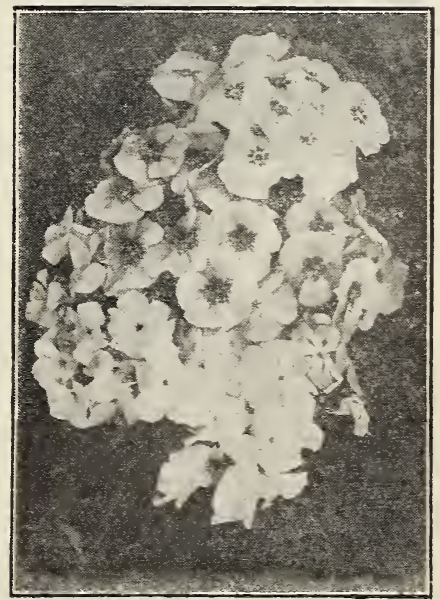

Phlox Drummondi 


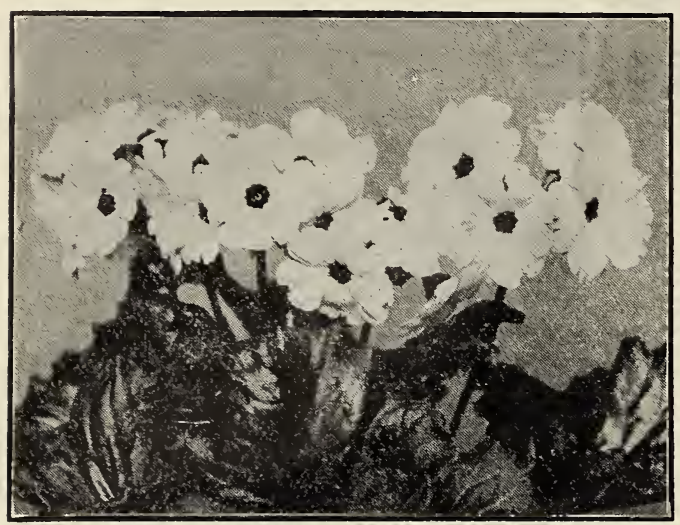

Primrose Obconica Grandiflora

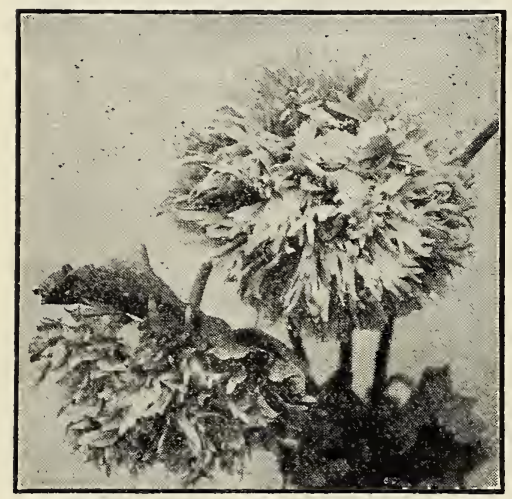

Double Carnation-Flowered Poppies

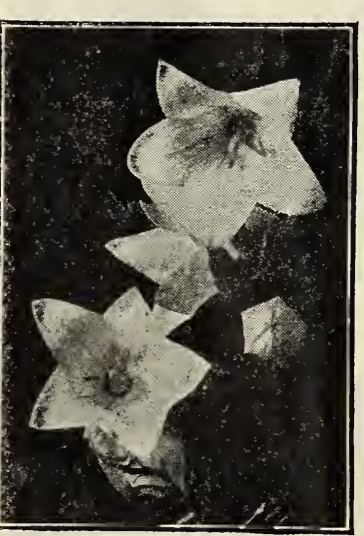

Platycodon

\section{SPECIA} plants at that time. and bloom the first season. SU IICE during their dormant season, in the late summer or early fall. We, being interested in the success of our customers, will fill all orders for poppy

\section{Platycodon (Japanese Bellflower)}

One of the best hardy perennials, producing large, showy, blue and white bell-shaped flowers during the whole season. Branching bushes 2 to 3 feet, easily grown from seed

Blue. Pkt., 10c. Mixed Colors. Blue and white. Pkt., 10c.

PRIMROSE Obconica Grandiflora $(\mathrm{H})$. One of the finest and most important winter blooming pot plants. Can be easily grown in any light window, flowering abundantly and continuously, bearing immense trusses of large flowers in choice assortment of colors, from pure white and soft pink through the different shades of rose and red to the brightest crimson. Pkt., 25c. Plants, 30c each.

PYRETHRUM, Aureum (Golden Feather)' (P). Beautiful rich yellow foliage; small pure white flowers; one of the best plants for edging, carpet bedding, etc. 6 inches, Most successfully treated as an annual. Pkt., 8c. Roseum (Painted Daisy), Mixed (P). Fine, showy, well-rounded plants 2 to $2 \frac{1}{2}$ feet tall, with finely cut, fern-like foliage. The large, bright, daisy-like flowers are invaluable for cutting. being borne on long stems and lasting a long time. They range in color from pure white and light pink to brilliant scarlet and dark red, with bright yellow centers. Although they bloom practically all summer, they are at their best in June. Perfectly hardy and easily grown. Pkt., 10c. Plants, 30c each; 3 for 60c; 12 for $\$ 1.75$, postpaid.

RANUNCULUS (Buttercup) (P). A pretty double flowering bright golden yellow buttercup, blooming in great abundance in May and June. 12 inches. Effective either as a cut flower or grouped in the hardy border. Plants, 20 each; 4 for 50c; 12 for $\$ 1.00$, postpaid.

RICINUS (Castor Oil Bean), Giant Zanzibar (A). From seed of this variety, sown in the open ground in May, the plants are in full foliage early in July. They attain a height of 12 to 14 feet and form a perfect pyramid of foliage and brilliant colored fruit, presenting a beautiful tropical appearance. Enormous leaves, 2 to 4 feet across, and highly colored light and dark green, coppery-bronze and dark green with reddish ribs. Pkt., 10c; oz., 20c.

RUBBER PLANT (Ficus Elastica) (H). Dark green, shiny foliage. One of the most satisfactory house plants. Being of tropical nature, the plant is at its best under moist conditions and high temperature. $\$ 1.00$ each.

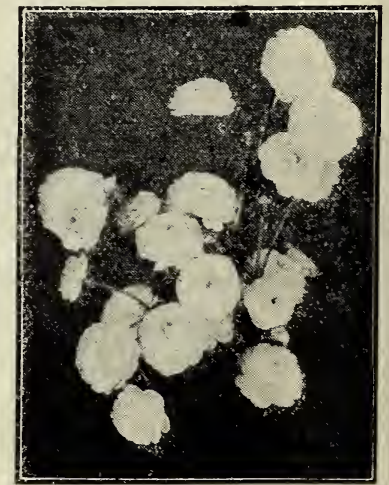

Buttercup (Ranunculus) 


\section{Salvia (Scarlet Sage)}

The Scarlet Sage has long been a favorite bedding plant. We here offer seed of the three finest varieties in cultivation.

AMERICA (A). This is the earliest, freest and most continuous bloomer of all Scarlet sages, and the most uniform in habit of
growth. The bushy plants do not grow over 15 inches high, with the spikes of brilliant scarlet flowers thrown well above the ioliage, miking a total height of about 2 feet. The importance of this uniformity will be appreciated by those who use Scarlet Sage for beds or borders. Pkt., 20c; 3 pkts., 50c.

BONFIRE (A). This is one of the finest of the Scarlet Sages, growing in a compact busli 2 feet high by 2 feet in diameter. Its green foliage and completely cover the plant. Pkt., 15c; 2 pkts., 25c.

SPLENDENS (A). This is the largest flowering Scarlet Sage, well-grown plants measuring 3 to 4 feet tall; a scorching scarlet other varieties. so seed should be started as early as possible. Plit., 10c; s pkts., „2jc.

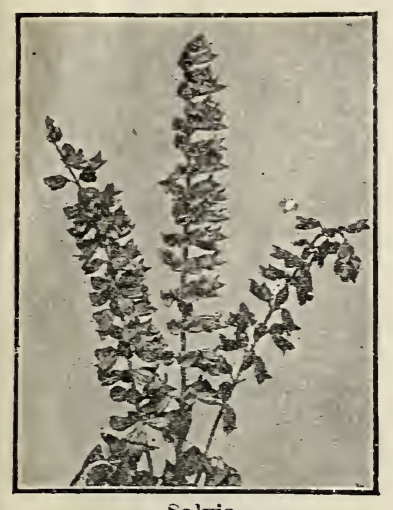

Salvia
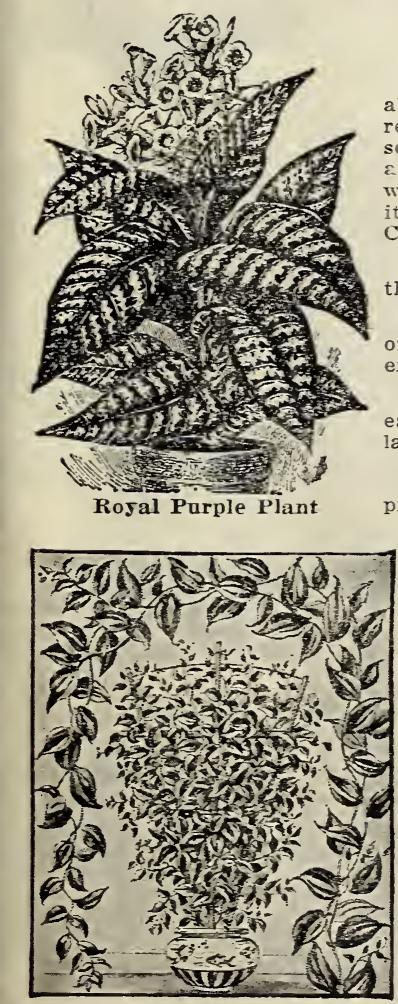

Smilax

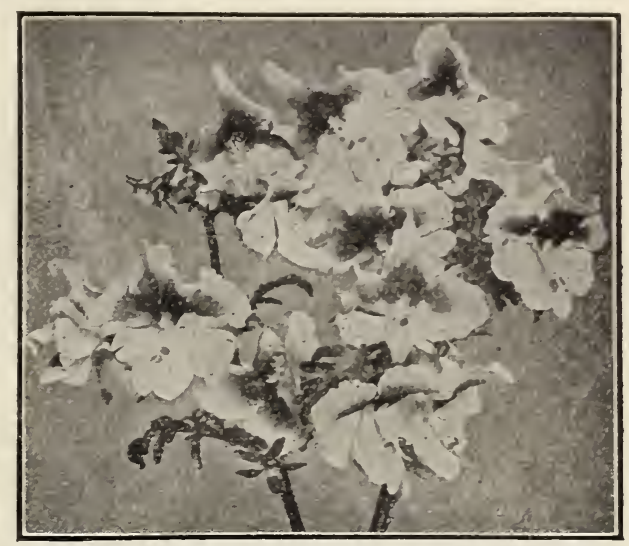

Schizanthus

\section{Hardy Perennial Salvia}

Tall spikes of pretty sky-blue flowers in great

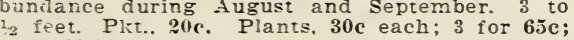
Ior $\$ 2.00$, postpaid.

\section{Schizanthus}

(Butterfly or Fringe Flower) (A). One of the daintiest flowers imaginable: especially fine for bordering beds of taller flowers, and as pot plants for the house in late winter and early spring. Seed sown in the spring will produce plants that will come into bloom in a few weeks, and with such loads of charming blooms as to completely obscure the delicate fern-like foliage. If wanted for house plants for winter blooming, sow in the autumn. The plants will quickly grow into compact, rounded bushes, about 2 feet tall. The butterfly-like flowers range in color from pure white through shades of cream and pink to crim-
son and mauve. Many of the flowers are beauson and mauve. Many of the flowers
tifuliy marked. Pht., 10c; 3 pkts., 25c.

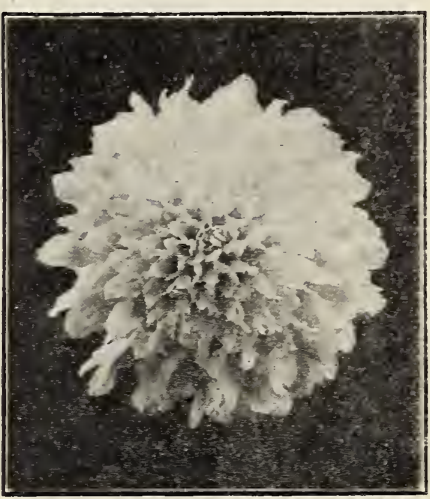

New Giant Shasta Scabiosa

SCABIOSA (Mourning Bride or Pin Cushion Flower) (A). A popular plant; grows about $21 / 2$ feet high, producing beautiful flowers of exquisite shades of pink, rose, cherry red, fiery scarlet, white, yellow, amethyst, lavender, light blue, dark blue and purple, the soft shades predominating. Begin blooming early in July, and when given plenty of room and the seed vessels are kept regularly picked off, will continue blossoming through the its floral flavors attract all the most beautiful types of butterflies to the neighborhood. Choice mixture of colors. Pkt., 5e.

New Giant Shasta (A). A pure white Scabiosa of enormous size, the flowers measuring hree and a half inches across, with extremely long stems. Pkt., 10c.

New Giant Peach Blossom (A). "Highly commended" by the Royal Horticultural Society of Great Britain. A beautiful shade of peach blossom pink, large size and long stems. An excellent cut flower. Pkt., 10c.

Perennial (P). The Perennial Scabiosa is one of the most handsome hardy perennials, especially valuable for cutting, the blossoms lasting a long time in water; color soft lavender-blue; 3 feet. Pkt., 10c.

SENSITIVE ROSE (Mimosa Pudica) (A). Curious and interesting plant with beautiful pinkish-white flowers. The leaves close and droop when touched or shaken. Pkt., 8c.

SILK OAK TREE (H). A magnificent plant for decorative purposes, of rapid, easy growth, "Silly cut foliage, and rivaling a rare Fern. Called Pkt., 10c; plants, 25c each.

SMILAX (F). One of the most desirable and graceful window vines. The slender stems are covered with small, glossy, green leaves. A fin plant for hanging baskets or window boxes. Elegant for bouquets and floral decorations. Pkt., 8c. Plants, 20c each.

ROYAL PURPLE PLANT (H). Tniversaliy popular on account of its brilliant and exquisite coloring. Surpasses the finest Coleus or Begonia in the color of its leaves. $30 \mathrm{e}$ each; 3 for $85 \mathrm{c}$, postpaid.

RUDBECKIA, Golden Glow (P). A well-known popular plant of strong, robust growth; 5 to 7 feet. Masses of double golden-yellow Dahlia-like flower from July to September. Plants, 20c each; 4 for 50c; 12 for $\$ 1.00$, postpaid.

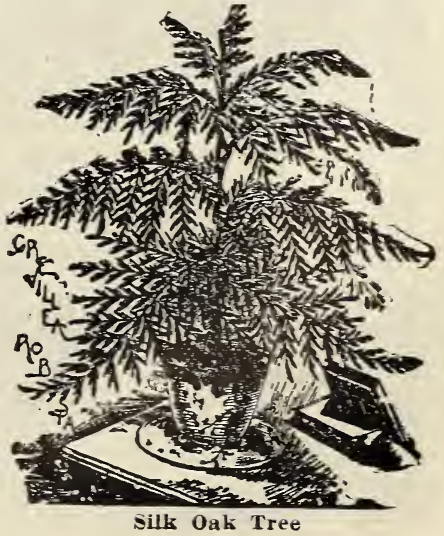




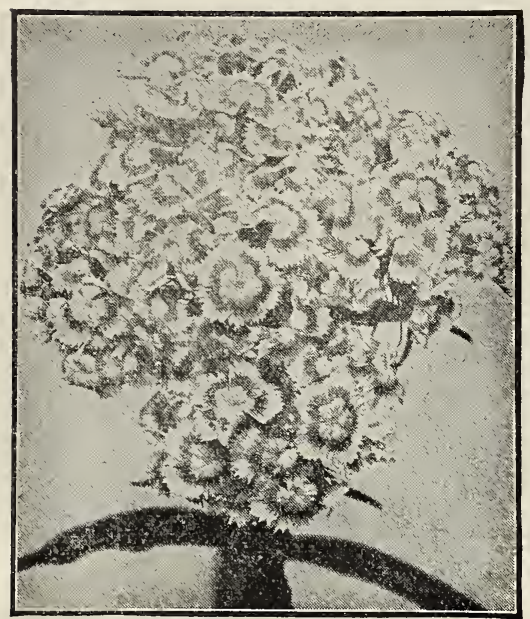

Sweet William

\section{Sweet William}

Popular garden flower, showing a wonderful array of vivid colors in fancy patterns, Flowers are shaped, clustered and colored much like Phlox, the markings, however, being more sharply defined.

Perennial. Pink, white, scarlet and crimson shades, some with beautiful colored centers and borders, variegated, biended and suffused. A fine mixture of both delicate and gorgeous colors. Seed and plants in mixid colors only. Pkt., 5e. Plants, 25e each; 3 for 60c; 12 for \$1.75, postpaid.

Annual. The annual Sweet William is almost identical with the perennial 作 unlike the perennials which do not bloom until the following year, these are annuals, blooming the same year the seed is sown. Plit., 10c.

\section{Sunflowers}

Double Chrysanthemum-Flowered (A). Rich golden-yellow: double as a Chrysanthemum and as large as a man's hat. 7 feet. Pkt., 10c; oz., 35c.

Red Sunflower (A). A unique and gorgeous novelty; plants grow branchingly, 3 to 4 feet high, and bloom freely. Flowers of different shades of red and red margined with yellow ranging from 2 to 5 inches in diameter. Pkt., 10c; 3 pkts., 25c.

Mammoth Russian (A). The largest variety of Sunflower, single heads measuring 12 to 22 inches in dianleter, and containing an immense quantity of seed, which is highly valued as a food for poultry, being one of the best egg producing foods known. Pkt., 10c; 1/4 lb., 15c; lb., 35 c.

SALPIGLOSSIS (A). One of the finest annuals, and of easy culture; 18 to 24 inches high; velvety funnel-shaped blossoms in a very large and unusual range of colors, crimson, prinirose, purple and gold, rose and gold, scarlet and gold, white and gold, etc. Continually in bloom from mid-summer until frost; splendid for cutting. The seed we offer is of the large flowered strain, and extra select. Pkt., 10c.

SILENE, Armeria (Catchfly) (A). A very showy early-flowering hardy annual about one foot in height, bearing in quantity, heads of beautiful white; pink and red fiowers. Any garden soil is suited to growing these free-blooming, showy plants, but they do best if not given too much care. Pkt., 5o.

SNAKE PLANT (H). A most striking decorative foliage plant. Very odd, beautifu and easily grown. No other house plant stands as much downright neglect and hardship. Nothing but frost or continued drenching with water seems to hurt it. It will stand gas and dust and will go for months without a drop of water. Plants, 35e each.

SNOW ON THE MOUNTAIN (Fuphorbia Variegata) (A). One of the finest foliage plants for outdoor planting. Foliage attractively veined and margined with white. 2 feet. Excellent for beds and borders. Pkt., 10e.

STATICE, Sinuata, Deep Blue (A). Not only one of the most beautiful flowers for the border, but dries retaining its true color, which makes it one of the most valuable of Everlastings; indispensable in making winter bouquets. Pkt., 8c.

Sinuata, Deep Rose (A). A rose-colored form of above. Pkt., 8c.

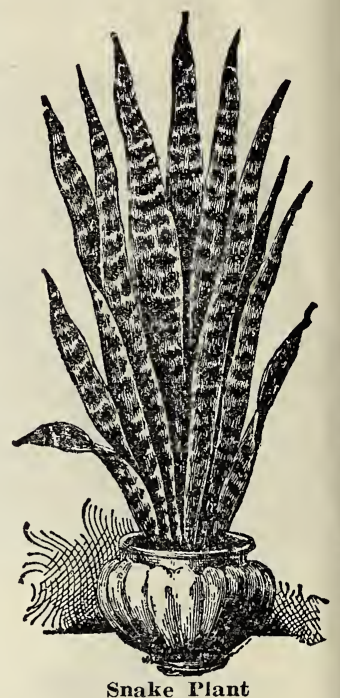

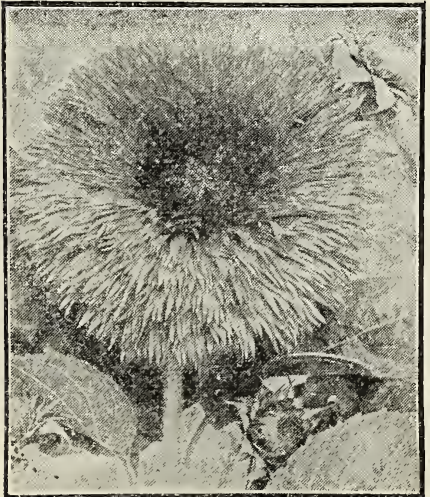

Chrysanthemum-Flowered Sunflower

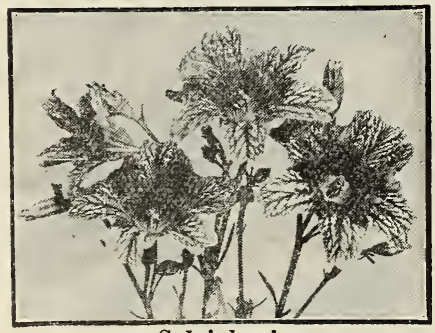

Salpiglossis

\section{Stocks}

The stock is one of the most popular annuals, either for bedding or pot culture. For brilliancy and diversity of color, fragrance, profusion and duration of bloom it is unsurpassed.

Large-Flowering Double Dwarf Ten Weeks (A). A satisfactory strain of stocks for all purposes. Extra large flowers. A fine mixture of colors, including white, rose, blood red, yellow, lilac, lavender, blue and purple. Pkt., 8c.

Mammoth Early Branching Nice (A). This variety is now recognized as the most valuable of all Stocks for cutting purposes and the most popular for general use. If sown early, they come into flower as early as Dwarf Ten Weeks varieties; the flowers are larger, and the branching habit renders them invaluable for florists. A choice nixture of all colors and shades. Plit., 10c.

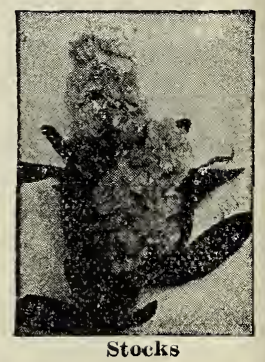

\section{Sweet Rocket (Hesperis)}

An old-fashioned perennial garden plant; also lnnown as Dame's Violet: grows from 2 to 3 feet high, and bears spikes of showy, fragrant flowers. Excellent for naturalizing among shrubbery or for planting in a permanent border; grand for cutting.

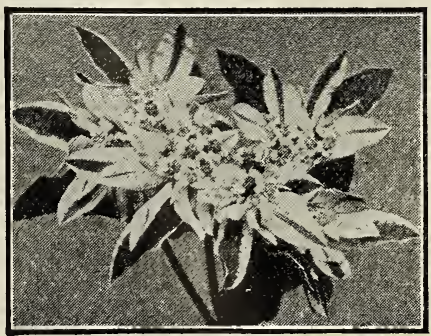

Snow on the Mountain
Lavender-Purple (P). Pkt., 8c.

White (P). Pkt., 8c.

\section{Stokesia Cyanea ( $\left.\begin{array}{c}\text { Cornflower } \\ \text { Aster }\end{array}\right)$}

A beautiful, hardy, perennial plant, growing 18 to 24 inches high, bearing freely from early in June until September its handsome cornflower-like lavender blossoms, which measure from 4 to 5 inches across. It is of the easiest culture, succeeding in any open sunny position, and not only is it desirable as a single plant in the hardy border, but it can also be used with fine effect in masses or beds of any size; indispensable for cutting. Pkt., 10c; 3 pkts., 25c. 


\section{FLUFFY RUFFLES}

THE NEW GINT RLFFLEI) SWEET PEA

I great, big flower, rigorous and free-blooming-the first of the Puflled Sweet Peas. A new type, duplexed and frilled with longstemmed, we 11-proportioned sprays of four almost globular flowers. No other Sweet Pea exhibits such a consistent doubling and ruffling of its petals. Twelve sprays make a more massive bunch than eigliteen sprays of an ordinary Spencer Sweet Pea.

A lovely rich rose-pink, a gleam of soft salmon, and a bright creamy undertone blend into a harmonious cream-pink shade that niust be seen to be appreciated. A flower of exquisite texture and fragrance. The rines make a sturdy growth and bear a profusion of blooms. Each fiower stem carries four fully developed blooms, artistically arranged. Ideal for bunching.

The highrst achierement yet attained in the most glorious of annuals is Fluffy Puffles-the Ruffled Sweet Pea. Pkt., 20c; 1/2 oz., :5e; oz., $\$ 1.45$

\section{Burgess' Prize Spencer Sweet Peas}

The spencer is the finest type of Sweet Peas grown. Beautifully formed flowers, many measuring 2 to 21; inches across, and petals daintily waved and rufflad. Many new varieties of Spencers have been originated during the past few years, and we have, this year, revised our list to contain on'y the very best of each color. Unsurpassed as cut flowers. Fvery lover of Sweet Peas should plant some of all of these selected varieties.

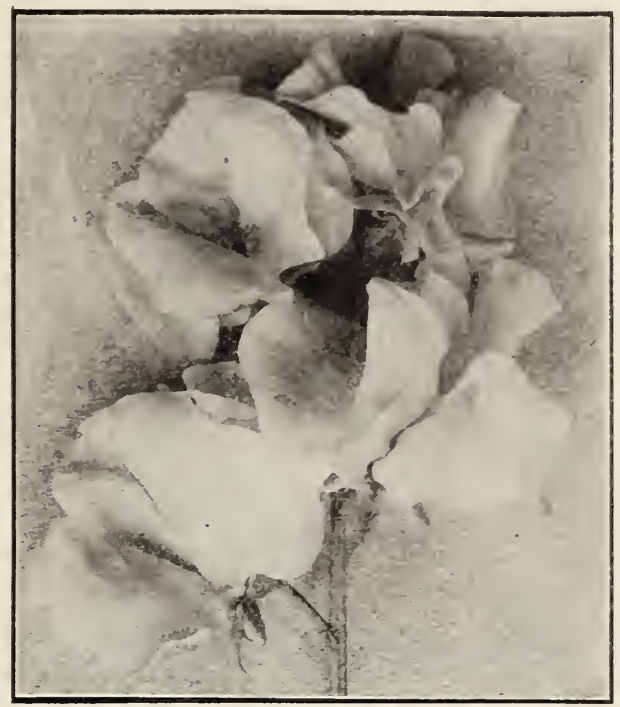

Flufi: Ruffles
BARBARA. Lovely soft salmon.

CHARITY. Rich briliant crimson.

CHERCB. Rich cream, edged pink.

ELEGATCE. Blusin-lilac.

HATIMARK CERISE. Rose-cerise on cream.

HEBE. Luminous clear pink.

FING WHITE. Pure white.

IrAMrOTH. Blazing orange-scarlet.

MART PICKFOI:D. Dainty cream-pink, suffused salmon.

MRS. TOM JONES. Delphinium blue.

PRICES: Tour choice of any of these Prize oz., $40 \mathrm{c}$

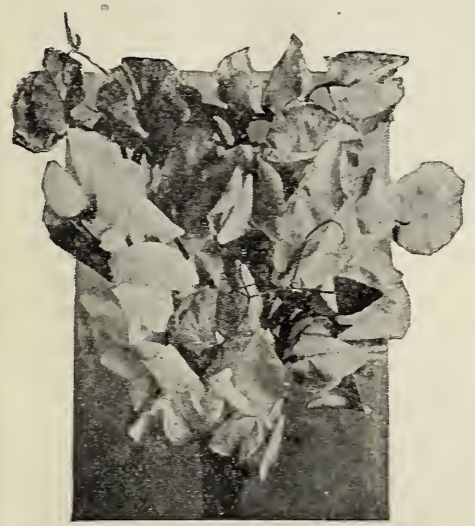

SPECIAL OFFER ties-for only $\$ 1.00$.

BCRGESS' SELECTED MIXTCRE OF SPENCERS is the most gorgeous mixture of Spencers ever offered. It contains the cream of the named Spencer varieties, including many recent novelties and superb new seedlings not yet introduced. It is the very best blend possible to produce and will surely delight all who want a grand variety of shades and colors. Pkt., 10e; 3 pkts., 20e; oz., 30c; 1/4 1b., 90c.

\section{Early Flowering Spencer Sweet Peas}

Our Early Flowering Strain of Spencer Sweet Peas is the result of more than ten year's careful scientific work. These varieties will not flower as freely and continuously as the late sorts, but will begin flowering from one to three weeks sooner, which is a decided advantage where early blooms are an important consideration. They are invaluable to florists for green house culture; for outdoor planting in sections of the Southern States where later varieties cannot be successfully grown; and for early blooms in cool climates. A choice mixture of all shades and colors. Pkt., 10c; 3 pkts., 25̃e; 1/2 oz., 30c; oz., 50c; 1/4 1b., \$1.50.

\section{Standard Varieties Mixed}

Cupid or Draif Sweet Peas

This mixture of Street Peas is the best of the old standard or Grandiflora varieties; a fine mixture of all colors and shades. There are no Spencers in this mixture. While it is our cheapest mixture and cannot be compared to the Spencer varieties, it is the best for the money that can be given. Plit., Je; oz., 12e; 1/. ib.. 35̈e.

\section{Cupid or Dwarf Sweet Peas}

The Cupid or Dwarf Sweet Peas grow 5 to 6 inches in height full-sized flowers; profuse bloomers. Excellent for borders. All the best colors and shades mixed. Pkt., 10e; 3 pkts. 20e; oz., $35 \mathrm{c}$.

\section{WE PAY THE POSTAGE}

on every.hing listed in this catalog except where we plainly state otherwise. 


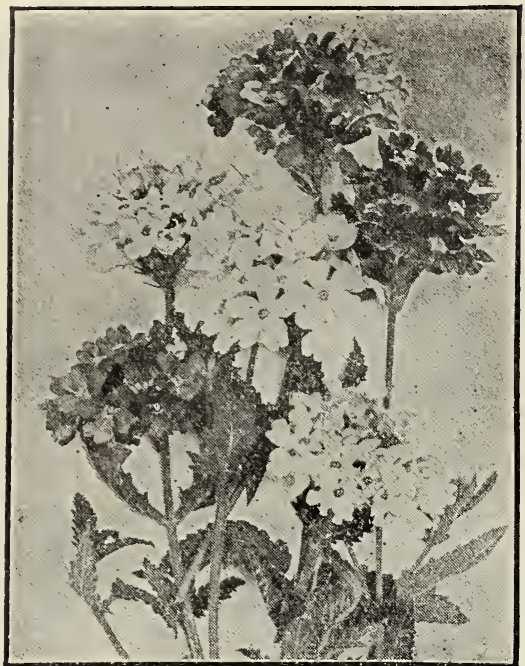

\section{Tritoma ( $\left.\begin{array}{c}\text { Red Hot Poler or } \\ \text { Flame Flower }\end{array}\right)$}

Pfitzeri (Everblooming Red-Hot Poker Plant) (P). The finest of all Tritomas. Grow 4 to 6 feet tall, the fiowers measuring 12 to 15 inches long by 4 inches in diameter. They are dazzling scarlet, the lower half of the flower being tinged with rich orange. A clump malies a triking passing the finest Canna for attractiveness. Bloom from August to October. If the roots are covered during the severe winter weather, they will live safely from year to year. Plants, $40 \mathrm{c}$ each; 3 for $\$ 1.00 ; 12$ for $\$ 3.00$, postpaid.

Early Perpetual-Flowering Hybrids (P). The first of the Tritomas to bloom; massive flower spikes 3 feet tall; flowers of various colors, ranging from pale yellow to deep orange-scarlet. Pkt., 10c.

\section{VERBENAS}

Our strain of mammoth Verbenas has been carefully selected and improved until we can recommend it as the best procurable. The trusses and individual flowers are of large size, of brilliant colors, free-blooming and of vigorous habit. The Verbena is one of the most popular garden annuals and lends itself willingly to many uses. For beds, borders and window boxes it is particularly fine, and is frequently used for an undergrowth to tall plants like lilies, etc. The clusters of showy flowers, are borne in constant succession from June until frost. We offer the following colors:
Blue (A). Plit., 10c.

Scarlet (A). Pkt., 10c.
Yellow (A) Pkt, 10e.

Italian Striped (A). Plit.. 10c.

Mixed Colors (A). Pkt., 10c.
Verbenas

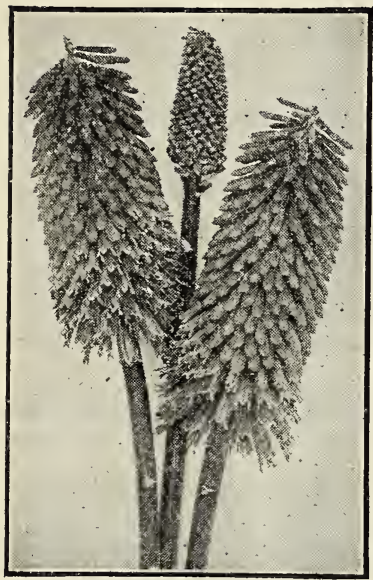

Tritoma
SPECLAL OFFER-5 packets of mammoth Verbena-one of each of the five colorsfor only 35 c.

Plants-in mixture of colors only-25e each; 3 for 65e; 12 for \$2.10, postpaid.

LEMON VERBENA (H). A universal and well known favorite that is grown principally for its fragrant lemon-scented foliage. It is a low growing, tender plant with white flowers; may be grown in the garden in the summer and in pots in winter. Its pale green delightfully scented foliage is fine for bouquets and goes well with any flower; leaves may be dried and laid among linens. No seed to offer. Plants, 25c each.

\section{VINCA ROSEA (Periwinkle)}

Ornamentai free-blooming plants, with dark, glossy, laurel-like foliage and handsome pink and white flowers. One of the most satisfactory and long-flowering bedding plants we have. They can be taken up in the fall like Chrysanthemums, potted, and kept in bloom through the winter.

Pink. Pkt., 8c. White. Plst., Sc. Mixed Colors. Pkt., 8c.

TRAILING VINCA (Variegated Periwinkle) (H). A beautiful variegated trailing vine, admirably adapted for hanging baskets and vases. The leaves are a glossy green, broadly margined a creamy white; flowers blue. No seed. Plants, 25c each.

VALERIANA (Garden Heliotrope) (P). Showy, hardy border plants; producing large flower-heads of deliciously sweet spicy fragrance; June and July, $2 \frac{1}{2}$ to 3 feet. Fine for bouquets.

Red (P). Pkt., 8c. White (P). Pkt., 8c.

VERONICA (Speedwell), Longifolia Blue (P). An elegant hardy border plant, growing 2 to 3 feet high; stout, erect stems; intense deep blue flowers; fine for cutting. July and August. Pkt., 8c.

Elegans (P). A form of Veronica, growing one foot high and having beautiful spikes of lavender flowers. Plants, 25c each, 3 for 50c; 12 for $\$ 1.50$, postpaid.

VIRGINIA STOCKS, Mixed (A). Early flowering hardy annuals that bloom between the spring and summer flowers, their bright colors in edgings and beds producing a charming effect. Pkt., כ̃c.

\section{VIOLA (Violet)}

CORNCTA (P). Flower continuously for nearly eight months in the year. Their bright colors and continuous riot of bloom make them welcome additions to any garden. Our seed is a choice mixture of all colors. Pkt., 10c; 3 pkts., 25c.

JERSEY GEM (P). Undoubtedly the most valuable bedding Viola yet introduced. Succeeds in any good garden soil in a sunny position, blooming practically without a break from May to the end of the season. The plant is of a compact sturdy habit of growth; flowers of large size; slightly perfumed; color is pure, rich violet; and borne on good stems about 6 inches long, making it a splendid subject for cutting as well as a most desirable plant for the border. Plants, 40c each; 3 for 90c; 12 for $\$ 3.00$, postpaid.

VIOLA ODORATA (Sweet Violet). Perfectly hardy; covered with flowers in early spring; wonderfully sweet scented; also suited for forcing under glass. We can supply seed of either Blue or White at 15c per packet; 2 pkts.- one of each color25c.

HARDY DOUBLE ENGLISH (P). This violet is entirely hardy, and if given a sheltered place, will usually begin to bloom before the snow is gone Deep violetpurple color and most deliciously fragrant; perfectly double. Will grow and bloom in any garden, and does especially well in the shade. Nothing is more appropriate for cemetery plots than the Hardy English Violet. Plants, 30e each; 3 for 80c; 12
for \$2.60, postpaid.

WANDERING JEW (H). Beautiful, variegated foliage; splendid for hanging baskets, porch boxes, etc. Very rapid grower. Plants, 20c each; 3 for 50c, postpaid.

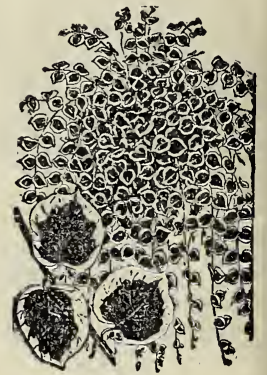

Trailing Vinca

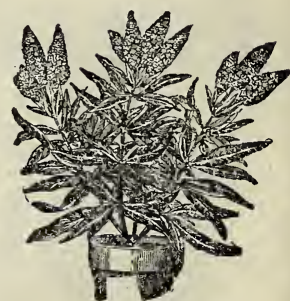

Lenion Verbena

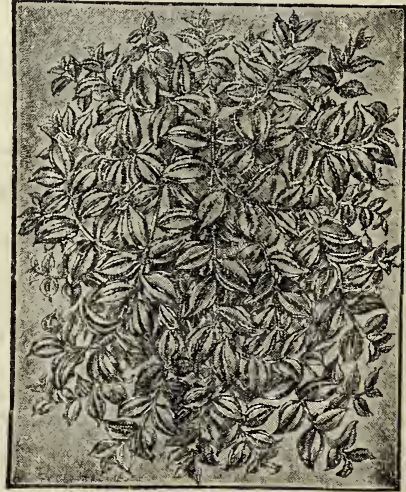

Wandering Jew 


\section{Water Hyacinth}

A beautiful water plant for the house. forming a lovely rosette of ghining green leaves and throwing up spikes of exquisite lilac-rose flowers resembling Hyacinth blooms. The most beautiful effect is produced by using a glass small amount of soil used. It is a most useful plant for aruariums, as fish will not thrive unless enough piants are growing to furnish them with oxygen. To do this there should be not less than one plant to every two gallons of water. Plants, $30 \mathrm{c}$ eacin; 3 for $8 j \mathrm{c}$, postpaid.

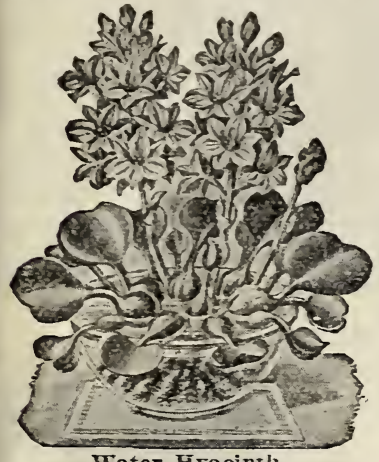

Water Hracinth

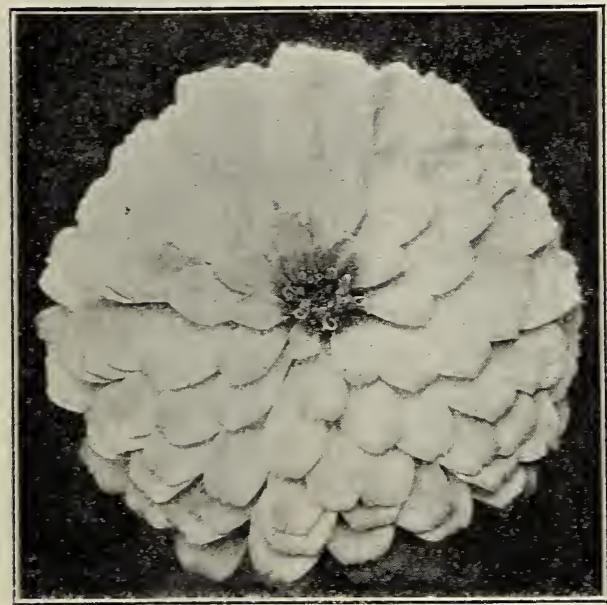

Giant Dahiia-Flowered Zinnia

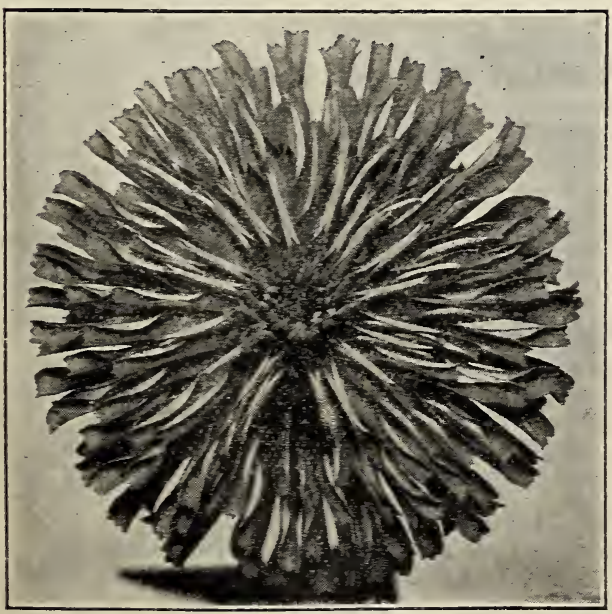

Curled and Crested Zinnia WALL FLOWER

WAX PLANT (H). Handsome pot plant, growth; frosted, waxy appearance; beautiful pink flowers, and almost always in bloom. for pot culture and exquisite fragrance of their flowers should win their. The oriental coloring of the flowers in They are easily grown and last long as cut so should be taken into the house when fall frosts are expected, or wintered in cold YUCCA, Filamentosa (P). Sometimes called Spanish Bayonet and Adam's needle. A distinctive, hardy evergreen plant producers; 4 to 6 feet. Groms Well on the poorest and
driest sandy soils where little else will grow. 30c each; 3 for $80 \mathrm{c} ; 12$ for

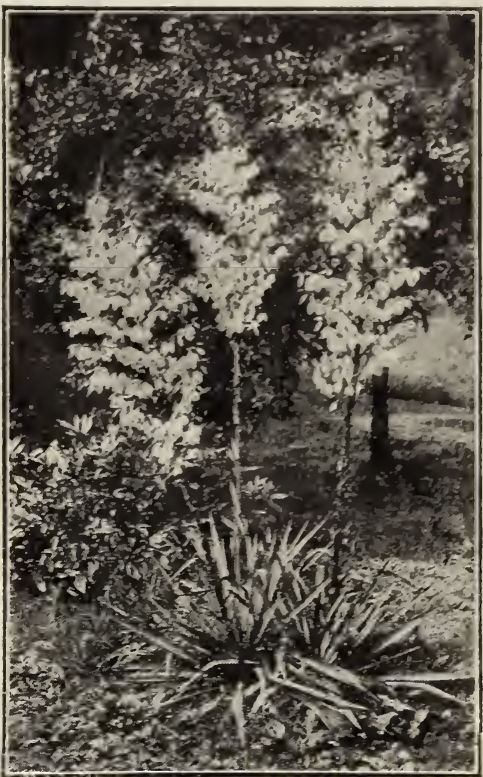

Iucca Filamentosa

\section{Giant Dahlia-Flowered Zinnia}

This trpe, the latest development in Zinnias, bears flowers of mammoth size and in form like a perf ct decorative Dahlia. The piant is a strong grower and flower stems are long and stiff. This remarkable variety includes a complete range of delicate, bright and rich colors from white, vellow, lavender and rose to orange, scarlet and crimson. A wonderful cut flower.

Crimson Monarch (A). Bright crimson-scarlet.

Dream (A). Deep lavender.

Exquisite (A). Pich rose-pink.

Oriole (A). Orange and gold.

Polar Bear (A). The best white Zinnia.

Finest Mixed (A). Containing a wonderful range of the above and other beautiful colors. Pkt., 15̄c; 2 pkts., 25e.

SPECIAL OFFER: Five packets-one of each of the abore separate colors-50c. One pht., 1Jc; 2 pkts., $25 \mathrm{c}$.

\section{New Curled and Crested Zinnia}

The peta's are elegantly twisted and curled, giving the flower a most attractive appearance. The plant grows 18 inches high by 2 frost. The colors range from white through many shades of yellow, Crested is a grand cut flower Which will last a considerabie time in wate. 3 plic.

Tall Double Zinnia (A). An extra select strain of fine double flowers of large size, but not equal to the Giant Dahlia-Flowered. Fine assortment of colors. Pht., 5c.

\section{Dwarf Zinnias}

Dwarf Double Scarlet (A). Pretty little bushes: covered the entire season with a mass of perfectly double intense scarlet flowers. A most efbouquets. Pkt., 8c.

Double Dwarf Mixed (A) A fine mixture of all colors. Pkt., 8c.

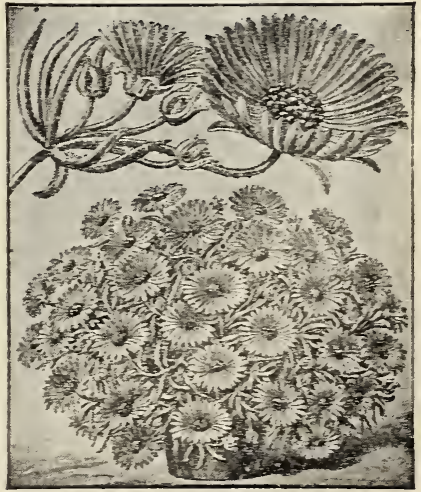

Wax Plant 


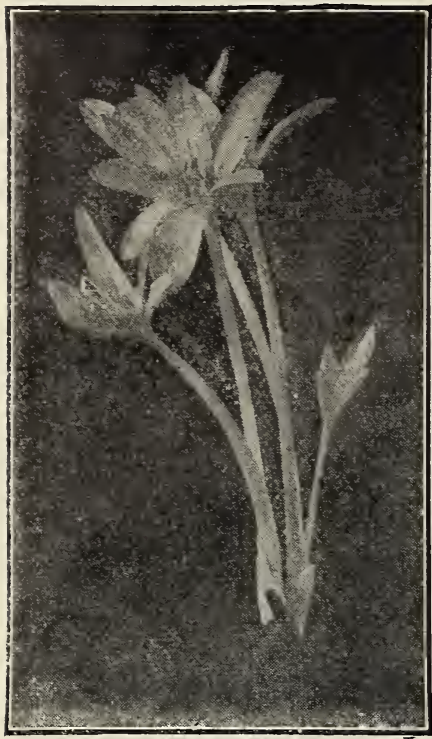

Colchicum

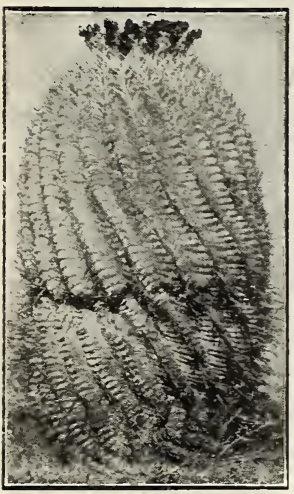

Fish Hook Cactus

We have two kinds of Desert Ferns, one being known as the Water Fern, the other the much advertised Resurrection Plant. The habits of these two plants are similar, but the foliage is entirely different. They are both peculiar and interesting, and admired by everyone; fine, fern-like foliage. These plants are usually lsept in a shallow vase or dish of water; require no soil. Curl up and go to sleep when taken out of water, and keep in their sleeping or dormant state for weeks, and awaken again in a few minutes after being placed in water. Owing to the fact they are capable of sleeping and awakening repeatedly, they are often referred to as the Opossum Ferns.

Water Ferns, 25c each; 3 for 50c.

Resurrection Plants, 15e each; 2 for $25 \bar{c}$.

SPECIAL One Water Fern and one Resurrection Plant,

\section{Fish Hook or Candy Cactus}

Wove ever offered. Covred with hook-like spikes which are exactly the shape of fish hooks and from $2 \frac{1}{2}$ to 3 inches in length. The hooks are very hard, almost as strong as steel, and as sharp as the finest manufactured fish hook. They have been used by Indians of the Southwest for fish hooks for many centuries. The famous cactus Candy is also made from this plant. The Fish Hook Cactus is easily grown from seed. With each packet of seed we will send complete cultural Tirections, recipe for making the candy, and on

\section{Perennial or Flower Seed Mixture} ground year after year and require very little care An easy and inexpensive way of obtaining them is to send for our Perennial Flower Seed Package of 25 Varieties. Package, 10c; 3 for 25c; 7 for 50e.

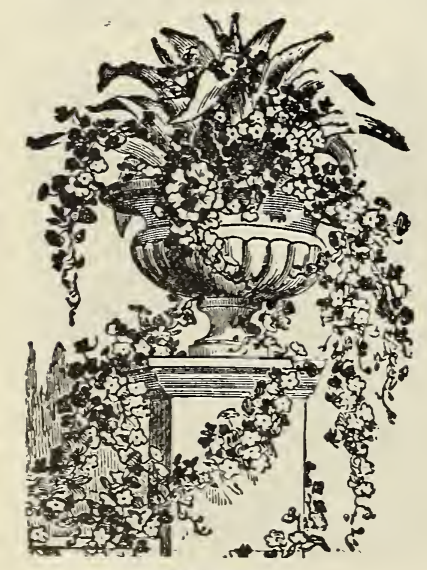

Vase Plants

\section{Genuine Oriental Flower Garden}

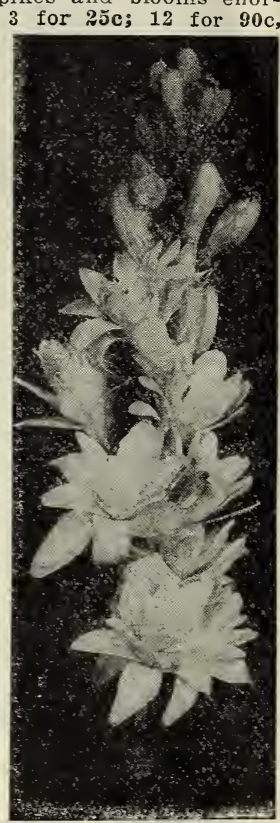

Tuberose

This is a special collection of Japanese and Chinese flower seeds; rare, scarce, curious, showy and most handsome varieties, entirely adapted to our climate. It is from Japan that we obtain many of our most beautiful flowers, such as Chrysanthemums, Irises, Lilies, Peonies, Oriental Poppies, etc., and many of our rarest, most curious, effective and showy varieties come from China. This Oriental Flower Garden contains a large assortment of varieties, all put up in one package. It would be expensive to buy them all in separate packets, as many of the varieties are very scarce, and not even offered by us in separate packets. Full directions for planting are sent with ment (1 package), 10c; 3 for 25 .

\section{Porch Box Plants}

PORCH BOX COLLECTIOY Yo, 1. Twelve plants, all different, our selection from the following list: Salvias, Geraniums, Wandering Jew, Ostrich Fern, Boston Fern, Vincas, Coleus, Petunias, Begonias, Verbenas, Hibiscus, etc. Price, collection, 12 plants, \$2.40.

PORCH BOX COLlectiox yo. 2. For box 8 inches wide by 3 feet long; 16 plants, our selection, from above list. Price, collection, 16 plants, \$3.20.

\section{Vase and Hanging Basket Collections}

VASE COLLECTION No. 1. Ten graceful, decorative plants of our selection such as Boston Fern, English Ivy. Lantana, Asparagus, Geranium, Petunias, Coleus, Variegated Vinca, etc. Price, \$2.20.

VASE COLLECTION No. 2. Same as above; 12 plants, our selection. Price, $\$ 2.40$

VASE COLLECTION No. 3 Same as above; 15 plants, our selection. Price, $\$ 3.00$. 


\section{Dwarf Fruit Plants for Pot Culture}

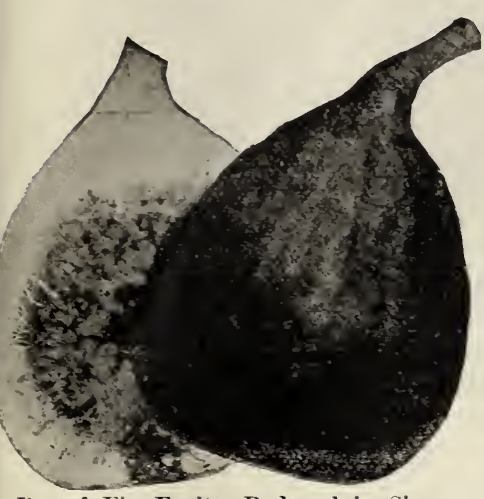

Dwarf Fig Fruits, Reduced in Size

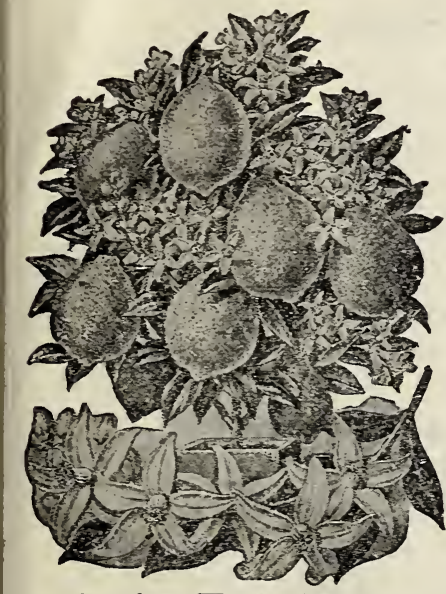

American Wonder Lemon

\section{DWARF FRUITING ORANGE A dwarf free-flowering}

is suitable for pot culture. While it will grow freely, it is not an uncommon thing to see little cutting plants five or six anges. The fruit at its best is not more than one-half the size of an ordinary orange, but it is very bright and beautiful in color and delicious in quality. Even though the fruits are fine, its beautiful flowers are what most strongly commend it for general cultivation. When it blooms it is
so full tliat it seems to be all flowers. The pure, waxy white blossoms emit a delicate yet powerful fragrance which is surpassed by no other plant. Plants, 30c each; 3 for 85c, postpaid.

\section{AMERICAN WONDER LEMON A}

be as easily grown in a pot as a Geranium and which produces fruit weigling from one to three pounds each. These enormous fruits are borne on lemonade and culinary purposes. Flowers are as fragrant as orange blossoms, which they somewhat resemble. The growth can be pruned to any size or shape; handsome as well as useful plants. Plants, 35 c each; 3 for 95e, postpaid.

IMPORTANT NOTICE Owing to quarantines, we do not ship Arizona, California, Florida, Georgia, Louisiana and Mississippi.

\section{Grow Figs in the North}

\section{Our Dwarf Fig is particularly adapted to pot} culture. As a pot or tub plant, it is extremely val uable either indoors or outdoors, and is an abundant safeiy in an ordinars cellar. or it can be ailowed to harden off with a few fall frosts and then be
brought indoors for growing during the winter. Our Dwarf Fig is a variety which fruits on the young wood, that is wood of the current year's growth, which makes desirable variety where the tops are likely to be frozen back. for if the top is frozen it can be gins growing, it will produce fruit on the new wood. It is for pot or tub culture that we particulariy recommend this Fig. but when grown in the open ground, it will develop a crop of fruit farther north than is true of other varieties. Plants bear the first year they are set and abundantly each year thereafter. The fruit is very sweet and delimeaty, and of very fine quality for making pre-
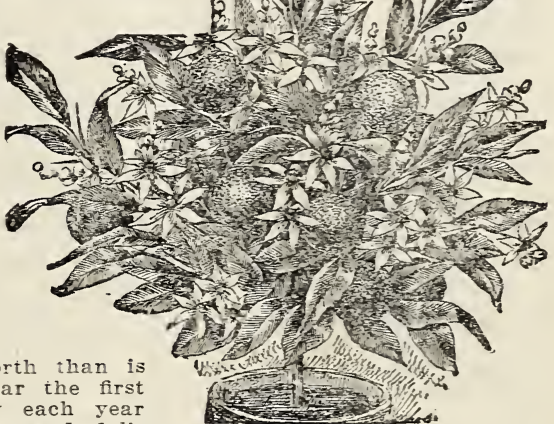

\section{SURPRISE OFFER} After Season Sales At the end of our selling season, we generally have surplus of all kinds of
piants, and rather than carry this stock over, we hold a clearance sale beginning June 1st, and make up surplus collections of miscellaneous plants at \$1.50 accepted any time before June 1st, and delivery will bo of plants. All must be strictly our selection. Orders state which you want-Fouse Plants, Hardy Perennials, or Shrubbery.

\section{IRIS (Flower-de-luce)}

The Iris is one of the most beautiful of hardy garden plants. Till grom almost anywhere, in out-of-the-way corners, among a well drained sunny position, barely covering the roots. Avoid fresh manure in preparing the bed. They require very little care, and will remain in the ground from year to year.

CELESTE. Light blue. Large flowers, 30 inches.

FLAVESCENS. Center petals light primrose; outer petals cream and rellow. 30 in.

HOXORABILIS. Golden vellow center; outer petals rich mahogany and gold. 18 in. KOCHII. Center deep blue; outer petals rich velvety dark purple; buds black. 2 feet. LORELEX. Center light yellow; outer petals blue, bordered with cream. 30 inches. MME. CHEREU. Pure white, daintily edged with light blue. 3 feet.

MRS. H. DARWIN. White, with faint violet markings. Finest white, 2 feet.

PALLDA DELMATICA. Enormous flowers of soft lavender; very fragrant. 4 feet.

PALLIDA SPECIOSA. Purple, with a slight touch of lavender and red. 30 inches. QUEEN OF MAY. Lovely soit lilac-pink. 30 inches.

FINE MIXED IRIS. Wonderful variety of colors, assorted, $\$ 1.00$ per doz.; 60c per half dozen, postpaid.

PRICES All named varieties of Iris, 25e each; 6 for $\$ 1.10 ; 12$ for 2.00 , postor more, $10 \mathrm{c}$ each.

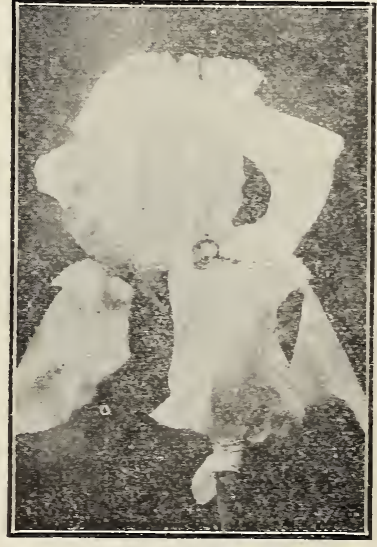

Mrs. H. Darwin Iris 


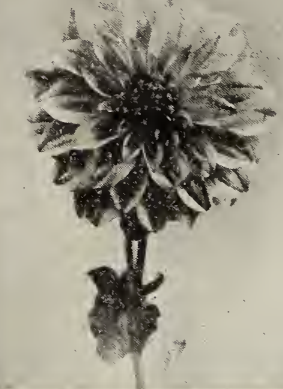

Decorative

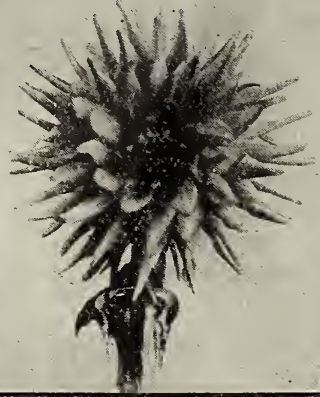

Cactus-Flowered

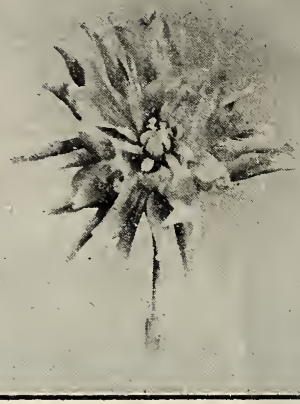

Hybrid Cactus

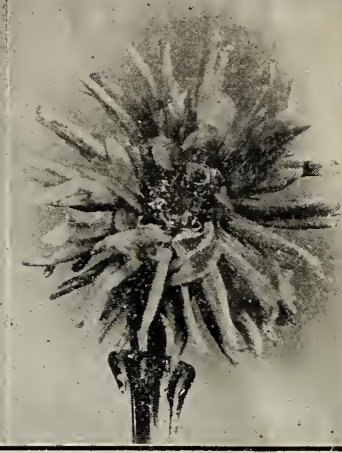

Peony-Flowered

\section{DAHLIAS}

\section{Decorative}

BONNIE BLCE. Unique in coloring, being one of the nearest blue shades ever produced in a dahlia. Each, 20c. DEE LIGHTED. One of the largest whites. It has an elongated center suggestive of the famous "Roosevelt Simile," whereby it gets its name. Each, 25c.

JACK ROSE. American Beauty shade of red; an old standard that can always be depended upon. Each, 15c.

JERSEY'S BEAUTY. Mammoth clear pink blooms produced on strong, rigid stems in great profusion. The petals are both broad and deep; lovely from every angle and considered by critics to be one of the best cut flower varieties. Each. $\$ 1.00$.

MRS. CARL SALBACH. Giant flowers of lovely mauvepink, shading lighter at the center and each petal outlined in deep mauve; fine for exhibition and cutting. Each, 50c. MRS. HARTONG. Fine flower of solid fawn color. Each, $30 \mathrm{c}$.

MRS. I. DE VER WARNER. A dahlia with few equals; enormous mauve-pink blooms on extra long, stout stems. Each, 75c.

PRIDE OF CALIFORNIA. Color crimson red with dark full center. Very fine flowers on extra good stems. Large. Each 35c.

MOROCCO. Large clear red, tipped white. Fine free bloomer. A variety that attracts attention anywhere. Each, 40c.

WHLLLAM REID BUTLER. Fine, large, wax white; petals of excellent texture. The plant often attains a great height and covered with large perfect blooms. Each, 25c.

SEABRIGHT. Shadings of apricot and buff. A tall and robust garden favorite. This large autumn colored dahlia is quite appropriate for fall decorations. Each, 25c.

ZCLU. Almost blue black. Each, 20c.

\section{Peony-Flowered} 35 c.

ADELE. Sulphur yellow; long stems and showy. Each,

CARNELLAN. Large cadmium-yellow, suffused pink. Each, 25c.

FOREST LOMA. Deep cerise-pink, blotched and streaked canary yellow at center. Very large. Each, 50c.

MAGICIAN. Large mauve-pink. Very free bloomer. Each, 35c.

MISS EDITH WALKER. Large primrose, tinted clear pink. Each, 25c.

PICADORE. White tinted lavender. Each, 20c.

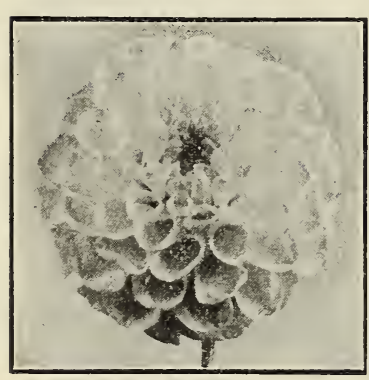

Show Dahlia

\section{Pompon Dahlias}

AMBER QUEEN. Amber tinted salmon-pink..Each, 15c BOBBY. A quite pleasing shade of plum......Each, 15c CHALLENGE Variegated white and maroon...Each, 15c GUIDING STAR. Pure white................. 15ach HIGHLAND MARY. Pink and white.................... 15c IILEIN DOMITEA. Bright golden terra cotta. Each, 15c MADELINE. Pale primrose edged rose purple.Each, 15c ZOE. Pure yellow ....................... 15ach

\section{Dahlia Bargains}

An assortment of Dahlias embracing all the types in a riot of colors, including many of the new ones and some of the best of the older kinds. The tubers we send out are strong and vigorous and are sure to bloom. This is your opportunity to secure Dahlias worth many tim s what they will cost you at our bargain

\section{Show}

ARABELLA. Sulphur-yellow, tipped pinkish-white. CALEB POWERS. White with lavender-rose shading. Cids are wide and reflex back to the stem. Each, 25c. MAUDE ADAMS. White suffused clear pink. This is without a doubt the best florists variety of the show type. his dahlia produces bloom in great profusion, Each, 25c.

QUEEN VICTORIA. One of the best show yellows.

\section{Cactus-Flowered}

COUNTESS OF LONSDALE. Salmon pink with golden FRANK GRAHAM. Large yellow ochre to salmon tip. J. H. JACKSON. Narrow incurved petals are of rich

Each, 30c

. GEO. WALTERs. One of the earliest to bloom. Each, 35̃c.

\section{Hybrid Cactus}

LIEL bloom of rose shaded suffusion. A MT. MORIAH. Massive size, deep buff shaded salmon pink. A dahlia of merit and distinction. Each, 75e.

CHAS. TURNER. Rank grower and profuse , Starts early and blooms

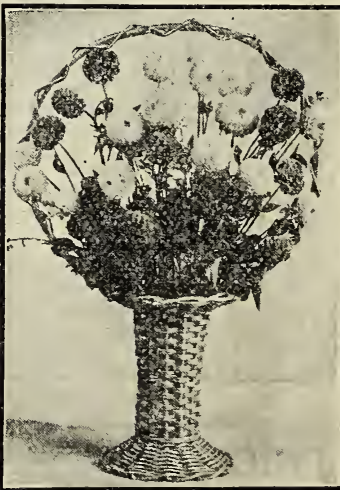

Pompon Dahlias 

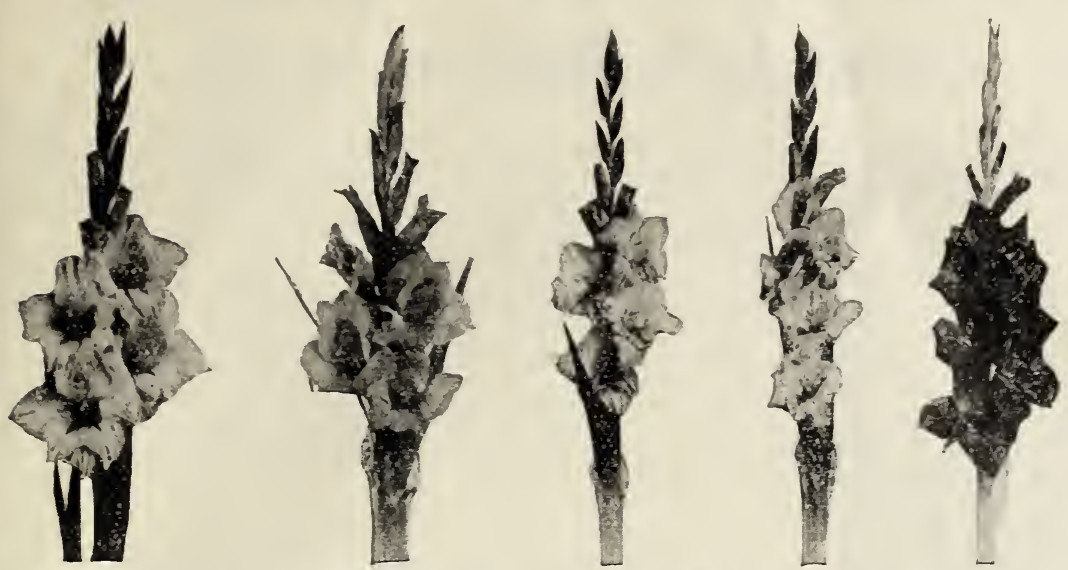

The ahove, left to right, are Rose Glory, Indian, Anthony B. Kunderd, Ruth Huntington and Lustre

\section{Choice Gladiolus}

The interest dereleped in the Gladiolus during the past fer years has been tremendous, and thousands of bulbs are now planted annually where dozens were used in the past. Their present popularity is sure to continue and increase, as they are. without doubt. the most attractive and useful of all summer-flowering bulbs. and, as a cut flower through the summer and autumn months, hold a place that cannot be taken by any other flower. Wonderful improvements are being made each year in size, color unless othitise stated. 25 or more at the 100 rate.

ALICE TIPLADY. Probably the most popular of the Primulinus species. Beautiful, large flowers of brilliant orange-saffron. Each, 10c; doz., 90c; per 100, \$6.00.

AMERIC. Soft lavender pink. Each, 5̈c; doz., 50c; per $100 . \$ 3.50$.

A.THOXY B. KCNDERD. Tall, large, intensely ruffied flower of delicate, deep cream color, overspread with the finest blush pink. The entire lower petals beautiful primrose-cream flushed pink at edges. Winner of many awards at the largest shows in the country. Ench, 20c: doz., \$2.00; per 100, \$13.75.

ACTIMT QCEEN. Color cream-yellow; upper petals suffused with peach-blossom pink; lower pe:a!s striped carmine red. Each, 8c; doz., 50 ; per 100, \$5.00.

BARON HCLOT. Deep indigo blue with fine hairlines of gold. Each, 10c; doz., 90c; per $100, \$ 6.00$.

BIRON L. SMITH. Beautiful delicate lavender-pink on a white ground; often spoken of as "Rivaling the Orchia.", Each, 15c; doz., \$1.25; per 100, \$8.00.

E.J. SHAILOR. Large rufied blooms of pure, deep rose-pink on tall, straight spikes. A worderful G!ad. Each, 15c: doz., \$1.25; per $100, \$ 8.00$.

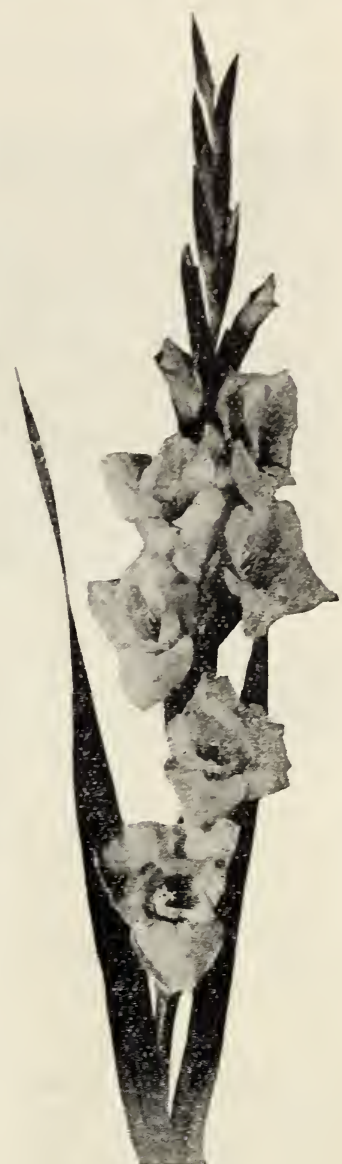

Los Angeles

HALLEX. Light sa!mon pink with cramy throat blotch striped with red. The earliest to bloom. Each, jc; doz., 50c; per 100, \$3.50.

IXDLAT. Strong plant, large well expanded flowers: many open at a time. Color, deep aniline or Indian-red. Each, 20c; doz., \$2.50; per $100, \$ 13.75$.

LE MARCHFL FOCH. Tery large flowers of a fine shade of rose pink. Each, 10c; doz. 90e; per 100 , $\$ 6.00$.

LCSTRE. Tall, large flowered, orange-vermilion. A grand flower. Each, 20c; doz., \$2.00; per 100, \$13.;5.

MAIDEXS BLLSH. Exquisite flowers of delicate pink, shading lighter at throat. Tall early Primulinus. Each, 10c; doz., 90c; per $100, \$ 6.00$.

MARY FEXXEL. Deep lilac, shading paler, with soft primrose rellow throat. Distinct. dainty and altogether lovely: Eacin, 10c: doz., \$1.00; per $100 . \$ 3.00$.

MARY PICKFORD. An extraordinary flower of delicate crimy wlite with a throat of softest sulphur yellow. Each, $15 \mathrm{c}$; doz., \$1.50; per $100, \$ 10.00$.

MRS. FRAXCIS FING. Long spike of immense flowers of light scarlet or flame red, shaded salmon. Each, 5c; doz., 50c; per $100, \$ 3.50$.

MRS. FRAXK PENDELTON. Tall, majestic spikes of rosa-pink blossoms bearing a giant blotch of richest, velvety carmine on lower petals. Each. 5c; doz., 50c: per 100. \$3.j0.

MRS. WATT. Briliant. glowing American Beauty red. Fin flowers of distinct color. Each, $10 \mathrm{c}$; doz., 90c; per 100 , \$6.00. IIR.A. Giant flowered Primulinus hybrid. Tellow with sa mon suffusion; throat, yellow with pink lines. The flowers are borne on lofty, graceful, siender stems. Each. 8c: doz., ijc; per 100. \$5.00.

PEACE. Extra tall spikes of pure white bloom with pale lilac featherings on lower petals. Large blossons. Each, 8c; doz., 75c; per 100 , \$5.00.

PRIMROSE BEACTY. Tall, strong, very large primrose-yellow. Each, 10c: doz., 90c: per 1no, s6.00.

ROSE GLOR:. A very large and splendidly ruffied flower of purest rose pink; deeper in the throat. Extra fine, Each, $15 \mathrm{c}$; doz., \$1.50; por $100, \$ 10.00$.

RCTH HCXTINGTOX. Beautiful violet-lilac with deeper lilac markings on lower petals. Strong plant; long spikes with finely ruffled flowers. Each, 25e: doz., \$2.50; per 100, \$17.50.

SCHWABEx. Large spikes of immense blooms of waxy yellow. Small brownish-red spot in throat. Each, 8e; doz., $75 \mathrm{c}$; per 100 , \$ร.00.

VIOLET BEACTY. Large ceriso-violet blooms with big red throat blotches. Tall spikes and good in every way. Each, 15c; doz., \$1.50; per 100 . $\$ 10.00$.

PRIZE MTTURE. This collection is made up of extra select varieties; sure to give satisfaction. All fine, large bulbs. One dozen, 60c; 2 doz., \$1.00; 50 for $\$ 2.00 ; 100$ for $\$ 3.50$, postpaid. By express not prepaid, \$13.00 per 500 ; or $\mathbf{8 2 5 . 0 0}$ per 1.000

BARGAT MINTCRE. Smaller bulbs than the Prize Collection, but all blooming size. 12 for 40 ; 36 for $\$ 1.00$; 80 for

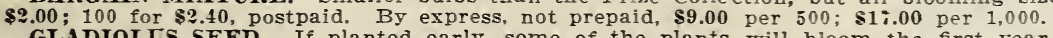

GLADIOLCS SEEn. If planted early. some of the plants will bloom the first year. Easily grown from seed. Fine mixture of colors. Pkt., 10c; 3 pkts., $25 c$. 


\section{Hardy Lilies}

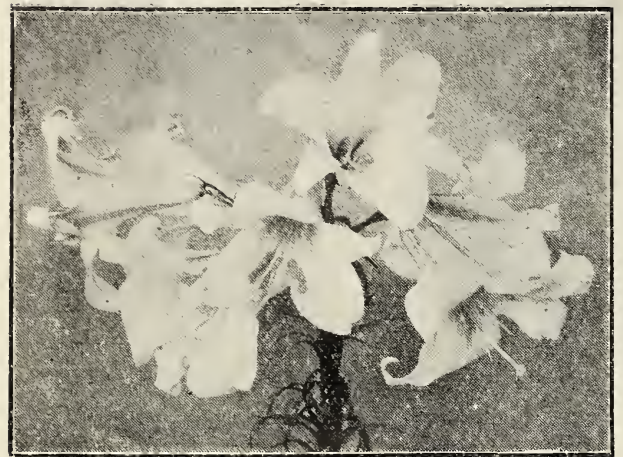

Regal Lily

Lilles are of the easiest culture, comparatively free from insect pests, and reed no dusting or spraying with poisons. The varieties listed below a re all perfectly hardy. After once being planted, they will increase in beauty and size with each succeeding year. Directions ior planting sent with all Lily bulbs.

REGAL LILY (Myriophylium). A recent introduction from northwestern China and one of the most beautiful of all Lilies. The flowers are white, slightly suffused with pinls; with a beautiful glow of canary yellow at center, which continues part way up the trumpet. They are borne in clusters and measure 4 to 6 inches in length, and are nearly as broad. Its perfume is excluisite; not oppressive like some types, but with the sweet refreshment of the Jasmine. In the garden it blooms profusely during July, continuing its glorious display well into August. Not only is it one of the hardiest and finest outdoor Lilies, but it is the one kind, above all others, that we can recommend to the amateur for forcing. As easy to grow as beets or carrots. 3 to 5 feet. $40 \mathrm{c}$ each; 3 for $\$ 1.10$. 12 for $\$ 3 . \tilde{0} 0$, postpaiã.

GOLD BANDEI) LTCY OF MAPAN (Auratum). Immense, fragrant fiowers, measuring nearly a foot in width when fully expanded, are produced in great profusion from July to September. Broad petals, gracefully recurved. White, thickiy studded with crimsonmaroon spots, with a wide gold band down the center of each petal. 3 to 6 feet. A woman in Towa writes that she had 75 blooms on one stalk and the stalk was 6 feet high. $35 c$ each; 3 for $\$ 1.00 ; 12$ for $\$ 3.25$, postpaid.

RED BANDED L"LY (Sneciosum Rubrum). No words can overstate the brilliant beauty of this famous Japanese Lily. Lerse for garden culture. 2 to 4 feet. August and September. 35e each; 3 for $\$ 1.00 ; 12$ for $\$ 3.25$, postpaid.

FIREFLA'E (F'egans सxtra Red). For a gorgenus display of rich coloring, very few flowers equal this improved type of Lilium Elegans. The brightest and most brilliant of all red Lilies. $11 / 2$ to 2 feet; blonm during June and July; large, erect flowers. The always dependable hardy red Lily. 40c each; 3 for $\$ 1.10 ; 12$ for $\$ 3 . \tilde{0}$, postpaid.

PINK PERFECTION (Krameri). Tnique for its color and grows from 2 to 4 feet high. The funnel-shaped, finely formed flowers are 6 inches or more in length and as much across, of a beautitul clear pink color, often shaded blush. 60c each; 3 tor $\$ 1.60 ; 12$ for $\$ 5.00$, postpaid.

GIANT TGER LILY. A grand Lily with large pyramids of orange-red flowers spotted with purplish black. August and Septembur. 4 to 5 feet. Cne $0:$ the hardiest and most easily grown. 25e each; 3 for roc; 12 for $\$ 2.2 \tilde{3}$, postpaid.

DOCBLE TIGER LILY. A double form of the popular Tiger Lily. Flowers are borne in large clusters during August and September. Very hardy, permanent, easily grown and exceedingly beautiful. 30c each; 3 for 85e; 12 for $\$ 2.75$, postpaid.

\section{Hardy Day Lilies}

BLU PLAYTAIY CILY (Funkia). Among the easiest ints to manage. Their broad massive foliage makes plants to manage. flower. They succed equally well in sun or shade. being ne of the few choice perennials which will accept a shady Incation without protest. Blue flowers in June. 35e eacli; for 90 ; 12 for $\$ 3.60$, postpaid.
LExIOY LIY (Hemerocallis Flava). Beautiful lemonyellow Howers in July and August: 3 to 4 inches in diameter, and delightílly fragrant. 3 feet. 25c each; 3 for $60 \mathrm{c} ; 12$ for $\$ 200$, postpaid.

GOLDEY LILY (Hemerocallis Fulva). Rich orange color with darker shading. 4 to 5 feet. June and July. 20c each; 3 for $\tilde{5} 0 \mathrm{c} ; 12$ for $\$ 1.60$, postpaid.

CINIJAMON VINE Beautiful, fragrant, easy growing, tuberous-rooted climber. Perfectly hardy, thrives quickly surround your windows. arbors and porches with a mass of vines, and protusion of small white flowers which perfume the air for a long aistance. 15e each; 2 for $25 \mathrm{c} ; 6$ for 60c; 12 for $\$ 1.09$; 30 for $\$ 2.00$, postpaid.

\section{PEONIES}

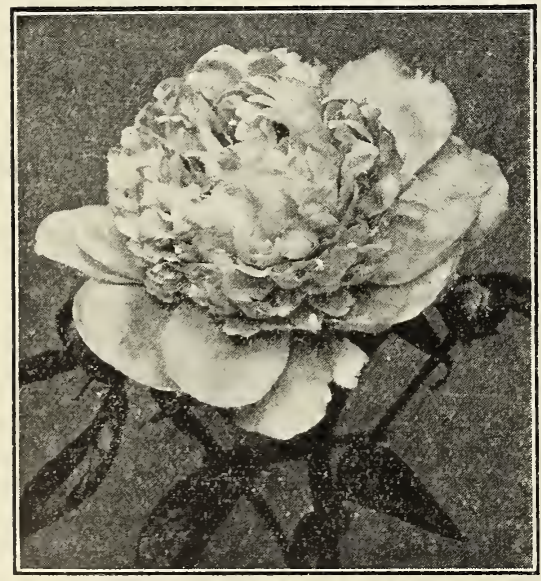

Edulis Superba
Chinese Pecnies are very desirable on account of their large size, fine colors and profuse blooming. They are perfectly hardy, and will succeed in any ground unless so wet the water stands on the surface in the winter and spring. May be planted either in the autumn or spring. Avoid planting too deeply. as this is often the cause of sly blooming; 2 inches of soil over the crown (eyes) being sufficient.

DUCHESS DE NEMOCRS. Fine early white variety. Strong grower and free bloomer; large double llowers; very iragrant. 60c each, postpaid.

EDULIS SCPERBA. The famous Decoration Day Peony; earliest variety; very fragrant; of upright growth: and one of the best. Large double blossoms; beautiful pink. 60c each, postpaid.

FESTIVA MAXIII. Large glnbular flowers. Pure white, with the center flecked crimson. Extra early, popular variety for cutting. 60c each, postpaid.

LEONE. Buds bright pink; flowers shell pink, changing to creamy white when fully open. A large beautiful flower. 60c each, postpaid.

COIIS VAN HOTTTEI. Rich deep crimson, with silvery tipped petals. Large round flowers; one of the best. F5e each, postpaid.

MLIE. VAILLANT. Outer petals creamy-white, blending to lemonyellow at the center. Very double and fragrant. 60c each, postpaid.

MEISSONIER. In some cut flower markets this Peony is known as the American Beauty on account of the resemblance in color to the rose of that name. Very brilliant crimson; full double flowers. A grand cut flower. Late. \%o each, postpaid.

CNNAMED PEONIES. Double White and Double Pink, 50c each; Double Red, 65c each. Three Peonies-one each of Red, Pink and Whitefor only $\$ 1.25 ; 3$ of each for $\$ 3.00$, postpaid. 


\section{Ornamental and Shade Trees}

BIRCH Cut-Lenred Weeping. Its tall, slender, yet vigorous growth vilage vresents a combination of attractive characteristics rarely met with in it single tree. Very popular for singte lawn specinlens or groups of three among the darker greens and browns une for \$\%.ov, or two or more at $\$ .25$ each, by parcel post, postpaid; by express, not prepaid, \$2.00 each or

EECHTEL'S CRAB Double Flowering. A fine, small flowering tree of being covered with delicut, pink roses. scenting the atmosphere for a long distance with a verfume surpassing the ragralice of the Tea Roses. The por the small jard. \$1.v0 each; 3 ivi \$\%.ub, uy parces post, postpailu.

CATALPA BUNGEII (Cmbrella Catalpa). Grafted on straight. top without pruning. Flourishes in all soils and climates. Leaves large. heart-shaped, deep green, lying like shingles on a rooi: always making symmetrical head. Tsually set in pairs on opposite sides of walk, entrance,
etc. One for $\$ 2.00$. Or two or more at $\$ 1.30$ eacli, by express. not yrepaic. Call not be sulit by parcel post.

CHINESE EIM As beatiful as the American Elm and has the adwhen it becomes bettr linown it will be the most popular of all shade trees. Grows as rapidly as the Cottonwood and the Poplars, and. being a tree without faults, is rapidly replacing other quick growing trees The picture below is from a photograph taken 6 years after planting, the trunk of the tree measurirg 34 inches in circumference 18 inches from the ground. If set at the same time as American Elms. the Chinese Elms will attain a lieight of 15 feet when the Americar Elms are groving only feet. In other words, you need not wait 15 to 20 rears for shade. as Chinese Elms will give luxurious shade in
5 to 6 years. With no other desirable tree can new homes enjoy the luxury

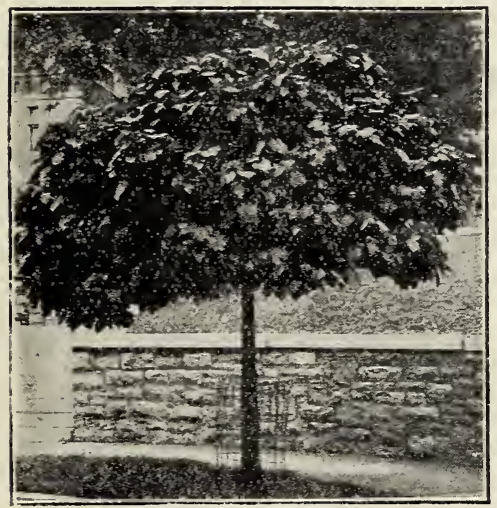

Catalpa Bungeii

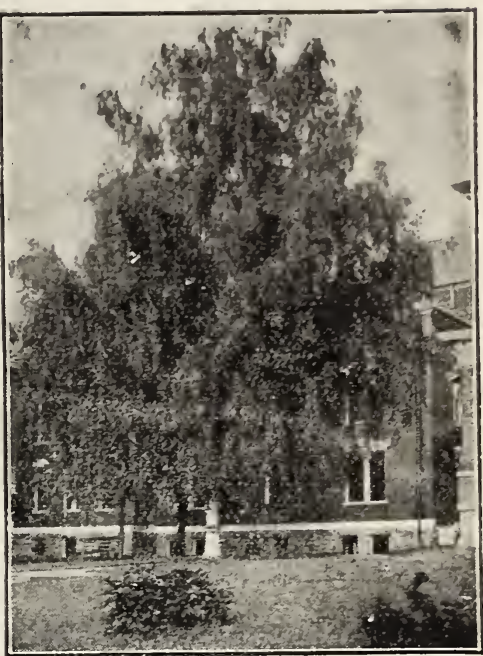

Cut-Leaved Weeping Birch windbreaks plant two or more rows with save ynur cherry crop as the birds prefer the Mulberries to clierries. For to the ground when planting so as to make them branch low. Mailing size plants, $30 \mathrm{c}$ each; 3 for $60 \mathrm{c} ; 7$ for $\$ 1.00$; 20 for $\$ 2.00$; 50 for $\$ 4.00$; or in lots of 100 or more at $7 \mathrm{c}$ each, postpaid.

\section{Bargains in Small Size Trees}

Small trees often transplant better than large ones, and mature into shade trees ncarly as soon. The trees we offer of the following varieties are real small sizes, the most of them running from 12 to 24 inches. It does not set them back to transplant them, like it does a larger tree. Large and small trees set at the same time will be almost identical in size at the end of a few years-never more than a year or two difference, and often the little trees will outgrow the large ones. Our young trees wiil make fine specimens, and what does an extra year or so mean in the growing of a nice tree for your lawn. This is your npportunity to get all the shade trees you want at very little cost. We deliver all these trees prepaid. Pick out what you want from the following list of varieties.

AILANTHTS (Tree of Hearen) ASH. American White BALM OF GILEAD

BEECH, American

BIRCH, White

CATALPA, Speciosa

ELI, American White

MAPLE, Silver or Soft

MAPLE, Hard

MAPLE, Ash-Leared (Box Elder)

IIII

IIOTTAIN ASH

MILPERRY. Russian

PERSIMION, American

POPLAT, Carolina

POPLAR, Lombardy.

RED PID (Judas Tree)

SYCAMORF. American

TCLIP TREE (Lirodendron)

WALNCT, Black

WALNCT, White (Butternut)

PRICES
Your choice of the above 20 kinds of trees, $30 \mathrm{c}$ each; 3 for $60 \mathrm{c}$; i for $\$ 1.00$, delivered to you by parcel post, postpaid.

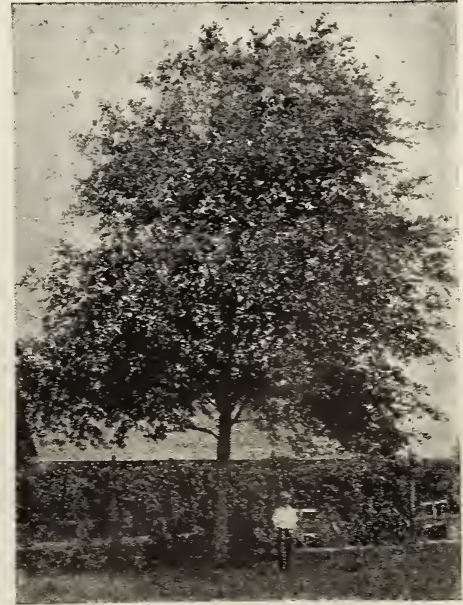

Chinese Elm

In April, 1927, Mir. George F. Luippold, Army Medical Center, Washington, D. C., purchased seven of our small size Lombardy Poplars, and on September 28, 1928, he wrote that three of them had made the remarkable growth of 12 feet. 


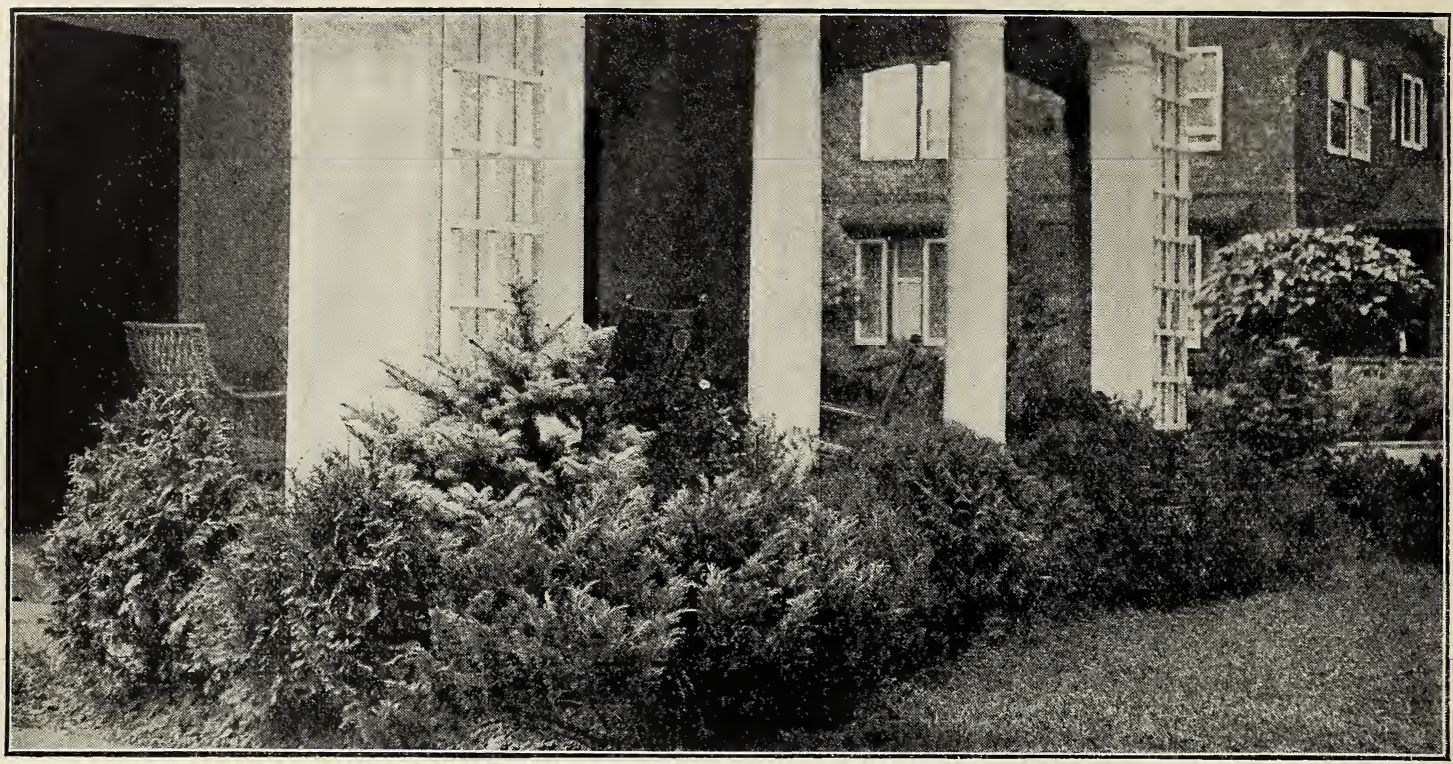

Foundation Planting of Evergreens

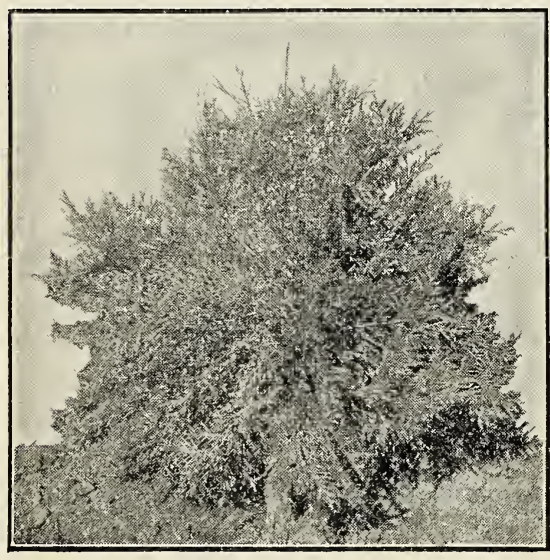

Golden Arbor Vitae

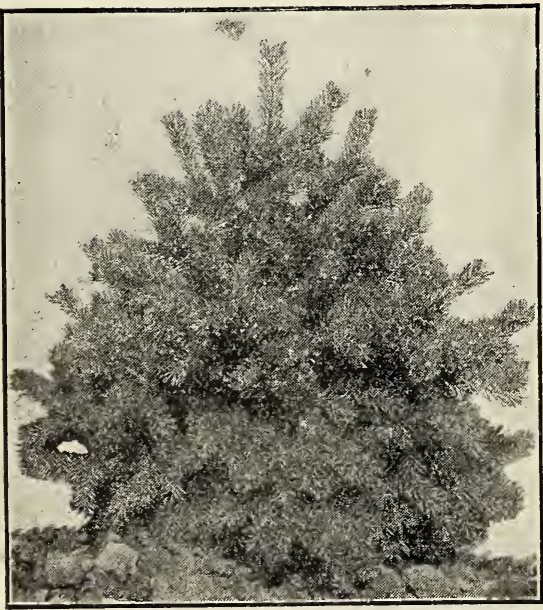

Scotch Pine

\section{Evergreen Trees}

Our Bargain Size Evergreens can be transplanted much more successfully than larger ones, and soon mature into the sizes you want for lawn specimens or foundation plantings. To purchase Evergreens of a large enough size for immediate effect, the cost would be considerable-often prohibitive. Large evergreens are very €xpensive. To persons who can not afford or do not wish to pay the high prices that are asked for large size Evergreen trees, we recommend our Bargain Size. In that way a pianting of Evergreens can be started NOW rather than to wait a year or two, or longer, to get the larger trees, and then purhaps n ver have then.

Our Bargain Evergreens are 3 to 5 years old and the different varieties will run from 8 to 15 inches in height. Evergreens of this size and age will transplant with fewer losses than those of any other age or size. Not only that, but they are just the right size and age to begin rapid growth and will often mature sooner than will much larger trees set at the same tims, and will develop into trees of nicer shape, and exactly as you want them. We will deliver them to you in good growing condition, and they will rapidly develop into fine and attractive specimens that you vill be proud of.

The best time to plant Evergreens is April and May. Evergreens can not be safely carried through the winter in storage, so can not be shipped until the frost is out of the ground in the spring. Some Southern planters have the mistaken idea that they should set out Evergreens earlier than the Northern planting season. This is true of most nursery stock, but not of Evergreens. Regardless of your climate, Evergreens should, for best results, be set out at the time the plants are in the proper transplanting condition. Our hardy, Northern grown Evergreens are the best for planting in either the South or North, and they are usually in the very best condition to transplant from about April 1st to May 20th. Send your order early. We will ship at the proper time for planting our Northern grown Evergreens in your locality.

Figures following specific names indicate approximately the height of the plant when approaching maturity. Grouping close together will have a tendency to keep them from growing large. The tall growing varieties can also be kept small by trimming. In other words, you can have trees of any size you want-4 feet or 60 feet-by trimming and by the proper grouping or massing.

ARBOR VITAE, American. 30 feet. A well known and valuable Evergreen for screens, windbreaks and hedg $s$ and as single specimens and landscape work. It has flat beautifuily carved foliage of deep green. Usually seen as a narrow, pyramidal tree 5 to $10 \mathrm{feet}$ high and half as wide, but will grow to be a large tree. It heads the list for Fvergreen hedge planting. For 3 to 4 foot hedge, plant 15 inches apart; 4 to 5 foot, 20 inches apart; 5 to 7 foot, 24 inches apart. 35e each; 5 for $\$ 1.25 ; 10$ for $\$ 2.25$, postpaid. 18c each in lots of 50 or niore, by express, not prepaid.

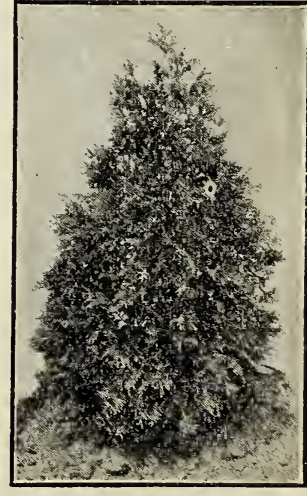

American Arbor Vitae 


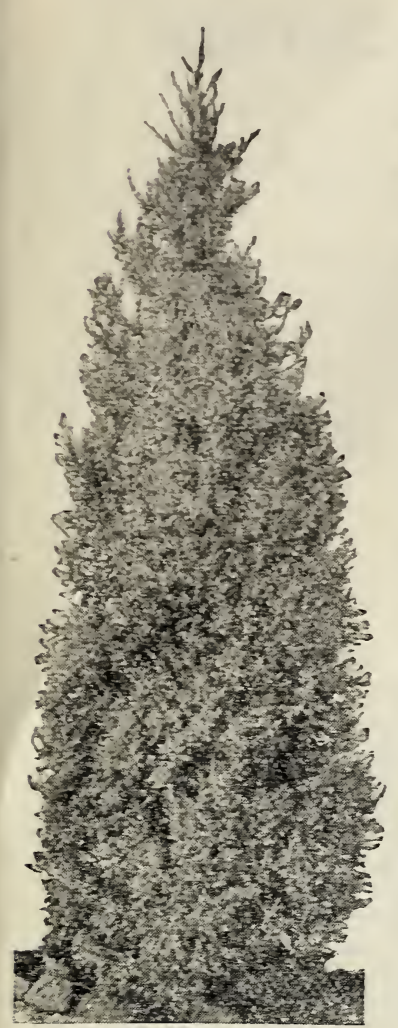

Juniper Virginiana

ARBOR VITAF, Globe.

foliage of a greyish cast. The neat globular out line adapts this Arbor Vitae for formal plantings, tub and wind Ev rgreen groups. ise euch: 3 for $\$ 2.00 ; 10$ for $\$ 6.00$, by parcel post, postpaid.

ARBOR VITAF, Goden. 15 fert. Foliage of a rery show goiden for there is nothing quite sn attractive in a group of Evergreens as a flash of \$6.00, by parcel post. postpaid.

ARBOR VIT.AE. Oriental or Chinese. 15 feet. A pyramidal growing evergren that

is green: dish inge, $45 \mathrm{c}$ each: 3 for $\$ 1.00 ; 10$ for $\$ 2.50$ by parcel post. postpaid. $20 \mathrm{r}$ more by express, not prepaid.

JIXIPFR. Irish. \& feet. Foliage bluish-green Very dene effect in landscape work. Makes â tall and Try narrow hedge. For a 3 to 4 foot hadge. plant 12 each; 3 for $\$ 1.50$ : 10 for \$4.00, by parcel jost. postpaid, $30 \mathrm{c}$ each in lots of 50 or more oy exprcs. not prepaid

JTIPER. Pfitzeriana. th and light bluish-green follag producing a beautiful. soft effect. Extreme! either shade or full exposure of the sin. Excel $\$ 2.50 ; 10$ for $\$ \mathbf{s . 0 0}$, b 5 parcel post, postpaid.

JUTPER, Tirginiana. 25 feet. Form tapering. symmetrical. Foliage varies from light green to grayish green and bluish green. color good at all times. but its bronzy appearance in fall and early winter is rerr attractive. Thrives well by parcel post. Dostpaid. 30c each in lots of 5 th

PINE. Scotch. 50 ieet, Here is where you $g$

all-round Evergreens to withstand extreme exposure and unfavorable conditions. Makes a big. broadshouldered tree highly resistant to wind or drought green needles. is rigorous in growth and maises a quick and attractive windor:ak. It is a handsome tree in its prime. and is used considerably bs land-
gs. 60 e each: 3 for $\$ 1.50: 10$ for $\$ 4.00$, by parcel post, postpaid 30 each in iors of 50 or more br express, not prepaid.

SPEICF Co bur Into this wonderful ornamental tree has been combind a silrery blue luster. periection ; and hardy characteristics that make it adaptable to nearly all climates. Ii can be used rery effectirely when planted indiridually. in groups by itself,

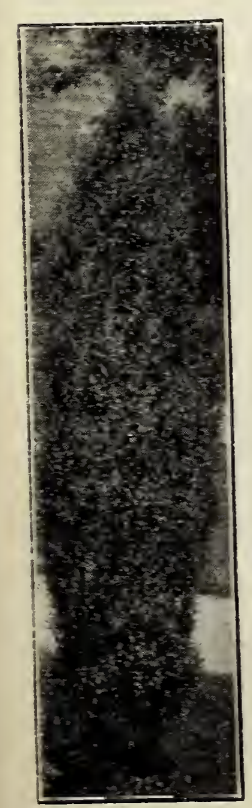

Irish Juniper display its coloring and form. In the spring of the year the Blue display its coloring and form. In thelanted will not regain their bluish color until they start to make a good growth. It is the new growth that brings out and renews the silvery luster, and i5e bluish tint b comes more in eridence bas parcel post, postpaid.

SPRTCE. Norwar. 50 feet. The Norway Spruce makes a large me looking tree. is the most rapid grower of the Spruces, thrives in a great variety of soils. is hardy everywhere. It stands close rlaning and serere pruning. It is the most popular tree for windbreaks and with its compact. buildings and grounds back of it. Fiedges 25 years old can be trimmed down to a height of four feet whereas the natural growth would be 50 to 60 feet. Foliage is dark green; needles short and stiff. In addition to its value as a windbreak and hedge plant it is orring to its beautiful form and foliage, probably more generally planted for landscape purpose than any of the other Spruces. For a 2 to 3 foot hedge, plant 15 inches apart; 3 to 4 foot. 20 inches - part; 5 to 6 foot, 2 feet apart: 6 to 5 foot, $21 / 2$ feet apart; $\$$ to 10 $\$ 1.25 ; 10$ for $\$ 2.25$, by parcel post, postpaid. $18 \mathrm{c}$ each in lots of 5 ?

\section{SPECIAL OFFER}

one each of the ten kinds of Evergreens offered on this page and page 60 . delivered to you. pre-
paid for only $\$ 4.00 ; 3$ of each for $\$ 10.00$.

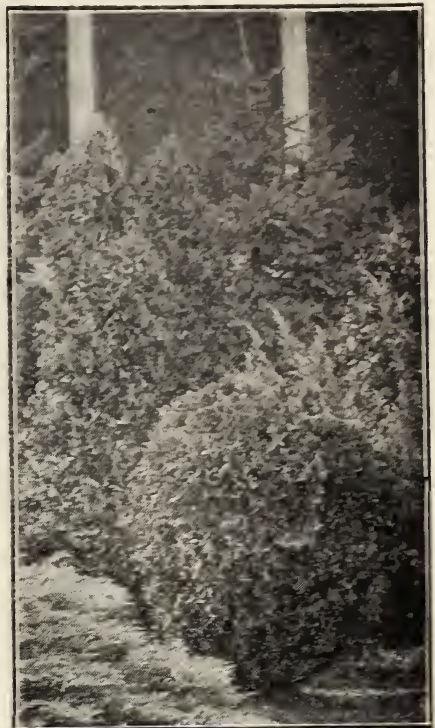

Globe Arbor Vitae with Oriental Arbor Vitae and Yorway Spruce in the background

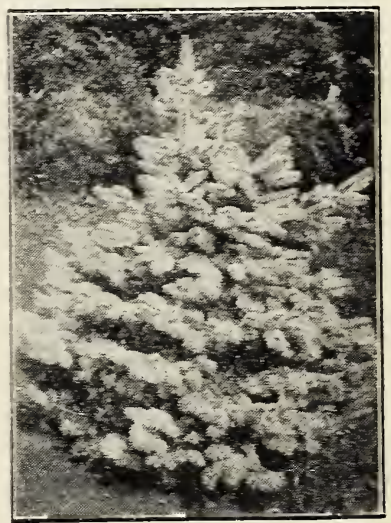

Colorado Blue Spruce

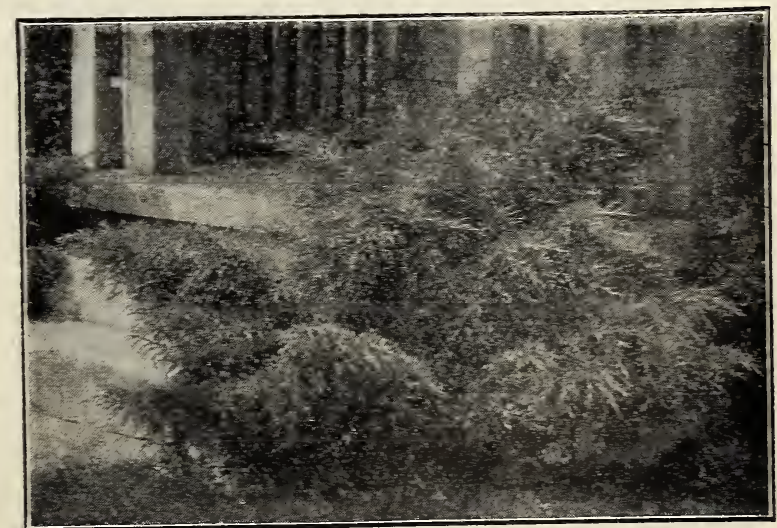

Juniper Pfitzeriana 


\section{Ornamental and Flowering Shrubs}

The shrubbery we offer is two and three years old; fine, tirifty, field grown plants which are sure to give the best of satisfaction. Due to the fact the average customer is not well informed on the correct way of trimning the various varieties of shrubs before setting them out, we are, this season, going to see that all shrubs are trimmed ready for planting before leaving our nursery. This is an added service which costs our customers nothing.

There are very few lawns which could not be improved in appearance by the addition of a few more shrubs, A small amount of money spent on shrubbery will beautify your home and greatly increase the value of your property. (A) denotes shrubs which attain 1 to 3 feet in height at maturity; (B), 4 to 6 feet; (C), 7 to 9 feet; (D), 10 to 12 feet; and (E), over 12 feet.

ALMOND (B). Early spring flowering shrub, gaily in full bloom before the leaves appear. with beautiful, double

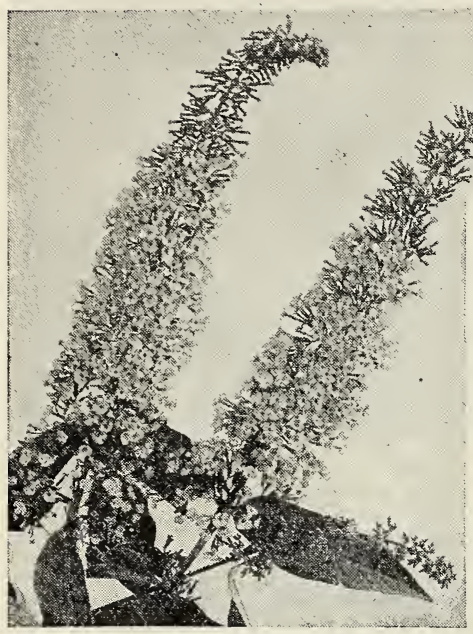

Butterfly Bush

CORNus ( Dog wood), Red Branched (C). Flowers creamywhite. Very conspicuous and ornamental in winter, when the bark is bright blood-red. 50c each; 3 for $\$ 1.25$.

Elegantiscima Tariegata (C). Purpish red branches and beautiful silvery variegated foliage. The most valuable variegated leav d shrub; capable of refined er mpact shape by pruning. A few of thes? set among the green-leaved shrubs produces a wonderful effect. Beautiful both summer and
ter. 85e each; 3 for $\$ 2.25$.

CYDONIA JAPONICA (Japamese Quince) (C). Tery ornamental. Double crimson flowers in great profusion early in the spring. 50c each; 3 for $\$ 1.25$.

\section{New Beauty Bush (Kolkwitzia Amabilis)}

An exceedingiy handsome ornamental shrub which has come to us from the wilderness of China. It grows 6 to 9 feet tall, with the inner stems erect or ascending and the outer ones arching to the ground, the whole plant forming a dome-shaped mass. The flowers are produced along the entire lingth of the branches in clusters at the ends of short leafy shoots. Thcy are tubular with a gaping mouth, deep pink without, stained with yellowbrown on the lower throat and lip. The pedicels and ovary are clad with spreading; white, bristle-like hairs which add to the attractiveness of the inflorescence. The flowers are borne in such profusion that the bush is on cloud of delicate pink. The graceful habit of the plant, its $y$ ar 'round beauty in foliage and habit, its free-flowering qualities and pleasing color. combined with perfect hardiness, malie this one of the most beautifui and useful shrubs. \$1.25 each; 3 for $\$ 3.00$.

\section{WE PAY EXPRESS CHARGES}

All Shrubs and Vines listed on this page are delivered prepaid by parcel post or express, to any part of the Lnited States.
Alwer (C). Bloom profusely in late sumare the color spots of fall as Lilacs and Weigelas are of spring. (C). $40 \mathrm{c}$ each; 3 for $\$ 1.00$.

ARALIA SPINOSA (E) Tall tree-like shrub of semi-tronical appearance. Broad handsomely cut leaves, often 3 or 4 feet long.

(B). Beautiful shrub of

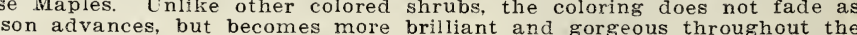
, and in the fall its foliage changes to vivid orange, scarlet and red the entire winter. in full exposure of lit brilliant coloring at all seasons is that it be ture pronounces it a true rust-resisting sport of the Japanese Barberry. 75e each; 6 for $\$ 4.00$; or 60 e each in lots of 12 or more.

BUTCERFCY BUSH (B). The most perpetual bloomer and one of the finest of all shrubs; flowers from carly summer until frost, and blooms the first season. Beautiful lilac-colored flowers borne on flower heads which frequently measure 10 inches in length. 50c each; 3 for $\$ 1.25$.

CAIICANTHUS FLORIDUS (Sweet Scented Shrub) (D). An interesting shrub, having a spicy, fragrant odor. Flowers of rare chocolate color; bloom in June and at intervals after. $75 \mathrm{c}$ each; 3 for $\$ 2.00$.

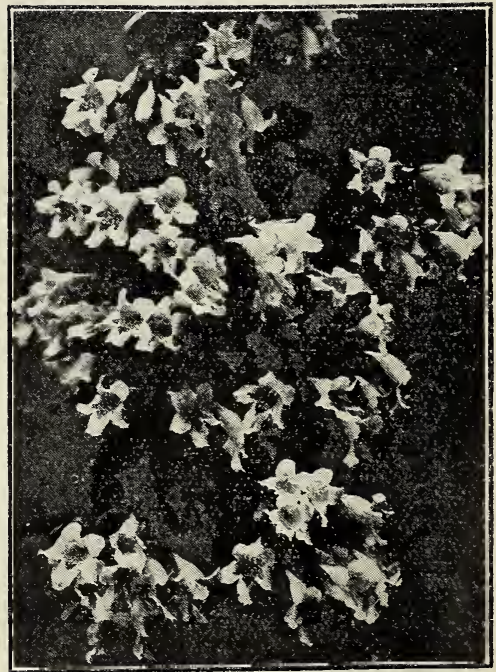

Beauty Bush, photo furnished us by Courtesy Arnold Arboretum, Harvard Cniversit 


\section{SHRUBBERY - Continued}

\section{CORAL BERFX (Srmphoricarpos Vulgaric) (B). Grace-} ul shrub; flow rs lint pink, oilowed ur c.usters of bright red berrifs, Which remain on the branches until
late in the winter. Very ornamental. 50c each; 3 for late in
$\$ 1.25$.

DETTZIA, Pride of Fochester (C). One of the most elegant shrubs ever produe dor t wicorous grower and oroduces its handsome thow $r$ in great profusin. Flowers White, with back

FORSTTHIA (Gnlden Bell), Fortuneii (C). Handsome shrub with gold
in :he suring.

ground is sti

house. 35c each; 3 for $90 \mathrm{c}$.

Intermeria ( $c)$. Tot so unright in gro

Suspensa (Weeping Forsthia) (C). Grace

lend $T$. droop... g lianchis.

for $\$ 1.25$.

FRINGE. Purple (Smoke Tree) (D). Conspicuous py mist-lile clouds of ting fotwers. The e billowing panicles of lighi lo.. nith give the impression ci smoke at

HONEYSTCKLE, Tartarian Pink (C). A large, handsom

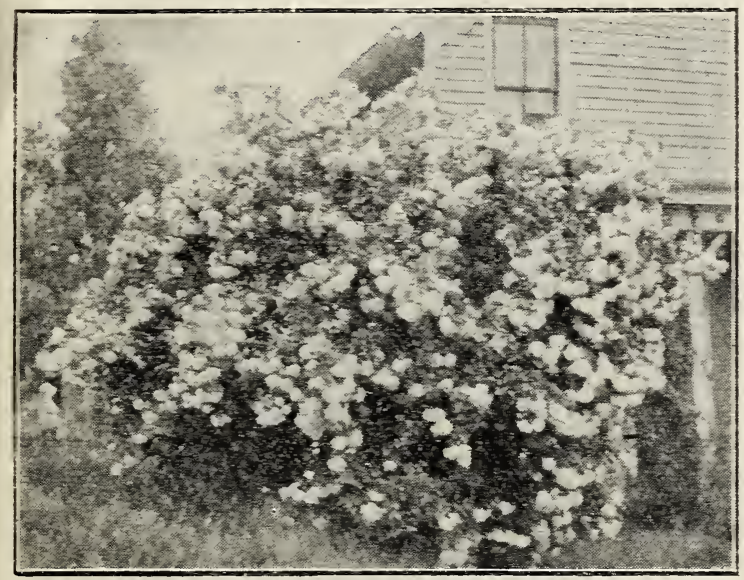

snowball fiotrets in

seen it deciar century. $\$ 1.00$ each: 3 for $\$ 2.50$.

Aurea (Golden Srringa) (B). Golden-rellow foliag

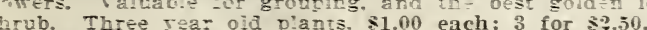

rub. Three yea: oid iful foliage; Will stand sh

Hultipies of. $13 \mathrm{c}$ each, by $\mathrm{e}^{-}$

Fern Leared Sumac) (D) turns to shades oi goiden yellow green, whicti in the lad, ciall effective if placed in the rear of lower shrubs. Flow作

icles, followed by Tud fruits thich are attractive in the autumn and winter. Extremely hardy: will thrive in any soil each: 3 for $\$ 1.25$.

SNOWHALL (Tiburnum Sterilis) (D). A well-known fa- ore shrub with globular clusters of pure white flowers the tor mat of XIsy. isc each: 3 for $\$ 2.00$.

\section{All Shrubs Delivered Prepaid}

A.! shrubs and rines listed on pages 62.63 and 64 are hardr, FIELD GROIN SIOCK, and not to be compared With the tincer grainhorise rooted plants of these rari.ties being offered at lower prices.

t'nless otherwise stated. all Shrubs and Vines are DELIVERED TRETIID at prices giren.

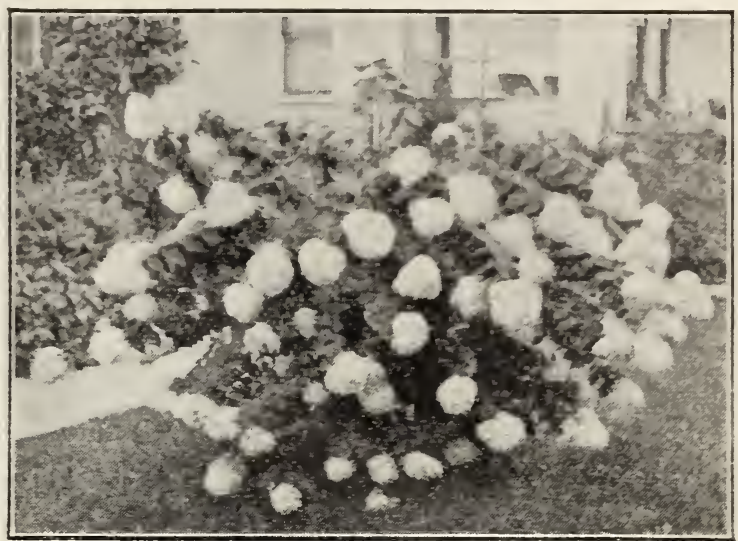

Hydrangea Paniculata Grand:flora 2 berries during 3 ic eacu; 3 for $90 \mathrm{c}$.

Tartarian White (C). White flowered variety of above. ¿ǰc each; 3 for $90 \mathrm{c}$

Morrowii (Japanese Bu-h Honersuckle) (B). A broad, each; 3 for $90 \mathrm{c}$.

HIDRANGEA. Fill of Snew (A). The rarliest bloom3 variery. Paniculata Grandiflora (C). One of the most magniffor $\$ 1.00$

LILAC. Persian Red (C). Tery graceful. Does not ire tacii; 3 for \$2.00. Purple (C). Dense panicles of purple flomers. The White (C). Pure white; Yory fragrant. 50c each. PHILADELPHTS (Srringa or Mock Orange). Coranarius ackgrounds. sortens.

for $\$ 1.00$.

Giant Flowered (D). Taller than Corararius: much Virginalis (Double srringa) (B). A magnificont new fall. One of the must desirable shruts. Many who have

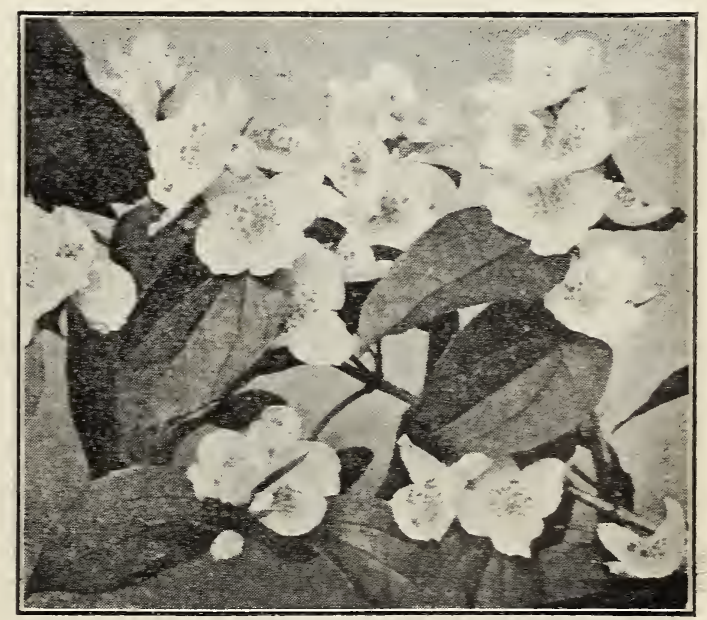

Philadelphus, Giant Flowered 


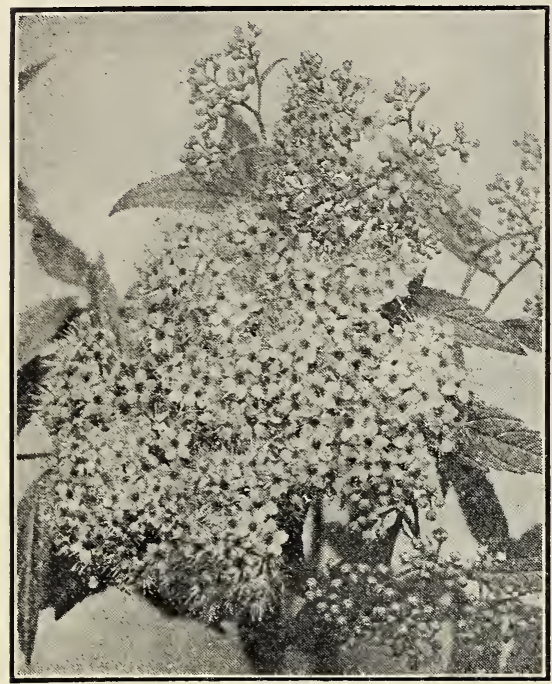

Spirea, Anthony Waterer

\section{SHRUBBERY - Continued}

SNOWBERRY (Symphoricarpos Racemosus) (B). A beautiful shrub with pinkish-white flowers in loose racemes, in summer, followed by clusters of snow-white berries, which remain on the branches until way
into the winter. 40c each; 3 for $\$ 1.00$.

SPIREA, Anthony Waterer (Perpetual Blooming Red) (A). Handsome round bush, $2 \frac{1}{2}$ to 3 feet in height and width. Begins to bloom in early summer, and if the dead blossoms are picked off, it will continue blooming until late in the fall. Bright red flowers in large clusters all over the bush. The most popular of all red flowered shrubs. 50c each; 3 for $\$ 1.25$.

Billardi (B). A grand shrub for planting in masses, and makes a wonderful cut flower. Spikes of beautiful pink flowers from July to October $40 \mathrm{c}$ each; 3 for $\$ 1.00$

Frobeli (Perpetual Blooming Pink) (A). Covered with clusters of beautiful pink flowers in june, and then blooms less abundantly throughout the remainder of the summer and fall. A handsome round shrub, about six inches taller than Spirea Anthony Waterer. 40c each; 3 for $\$ 1.00$.

Van Houttei (C). A leader among shrubs. and a beautiful ornament at all seasons. Sometimes called Bridal Wreath. A round and graceful bush with arching branches, covered with white flowers in the spring. No doubt one of the most useful of all shrubs. 30e each; 3 for i5c.

Aurea (Golden Spirea) (C). Of similar habit to Spirea Van Houttei; golden yellow foliage. One of the finest yellow-leaved shrubs. 50c each 3 for \$1.20.

TAMARIX (D). Fine feathery foliage like that of Juniper. Delicate pink flowers, borne profusely on graceful drooping branches, which have red bark. Hardy and will thrive in almost any situation; will do well in the poorest, dry, sandy soil. A beautiful shrub. 50c each; 3 for $\$ 1.25$.

WEIGELA, Rosea (B). Deep pink bell-shaped flowers in great profusion during June. An elegant and most popular shrub. 50c each; 3 for $\$ 1.25$.

Eva Rathke (B). An extremely showy variety; large, brilliant, crimson flowers completely cover the whole plant during early summer, and continues to bloom on the new growth through the summer and autumn months. One of the finest flowering shrubs. 85c each; 3 for $\$ 2.25$.

\section{We Pay the Postage or Express Charges on All Plants Listed on this Page}

\section{Hardy Climbing Vines}

(F) denotes vines that do extra well in shadry places. (G) denotes vines that do extra well in hot, sunny situations. ( $\mathrm{H}$ ) denotes vines that are especially suited for growing on north side of house. (I) denotes vines that are especially suited for growing on east side of house.

AMPELopsIS, Veitchii (Boston Ivy) (H). A grand hardy climbing vine for covering houses, churches, schools, etc. Clings firmly to the smoothest surface of rock or wood. The glossy leaves assume, in the autumn, the most beautiful tints of scarlet and crimson. The best vine in existence for growth on brick walls. Fine 2-year-old vines. 40c each; 3 for $\$ 1.00$.

Quinquefolia (Virginia Creeper). During the fall months it is the most beautiful of all hardy vines, the deeply cut leaves turning to a most vivid crimson color. Unsurpassed for covering trees, rocky slopes, fences, etc. $30 \mathrm{c}$ each; 3 for 75 c.

CELASTRCS SCANDENS (Climbing Bitter Sweet) (F). A most desirable climber; handsome, large leaves; yellow flowers in May and June and clusters of ornamental orange-capsuled fruit in Fine for late fall and winter decorations. $10 \mathrm{c}$ each; 3 for $\$ 1.00$.

CLeMATIS, Paniculata (Japanese Clematis) (G). The finest small flowered Clematis. Rapid grower; flowers pure white, fragrant, and produced very freely in large clusters. A very desirable vine. $40 \mathrm{c}$ each; 3 for $\$ 1.00$.

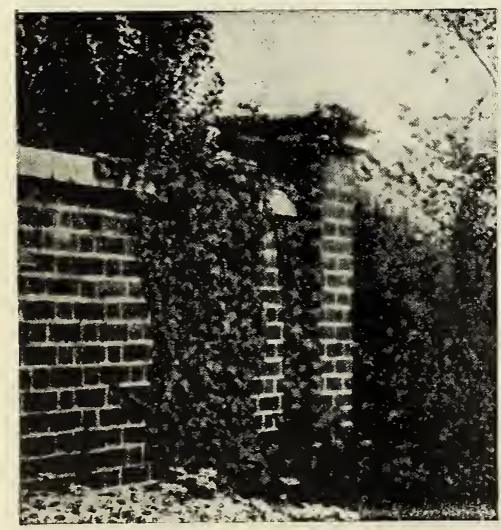

Boston Ivy on Brick Wall violet-purple. 90e each. crimson in color. 90e each. 3 for 60 c.

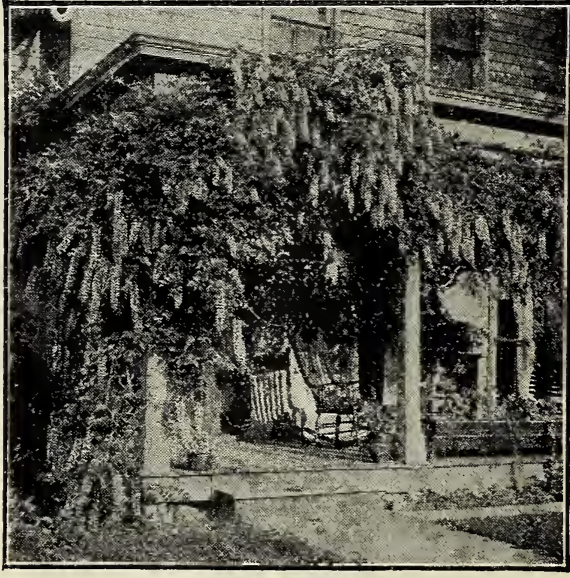

Wistaria

Henryii (H). Finest white Clematis. Flowers 4 to 6 inches in diameter. Blooms freely during summer and fall. Very hardy. 90e each.

Jackmanii (H). Same as Henryii, except that the flowers are a rich

Madame Andre $(\mathrm{H})$. Same as Henryii, except that the flowers are bright

DUTCHMAN'S PIPE (G). Brownish flowers, resembling a miniature pipe. An ideal vine for situations requiring dense shade: leaves deep green. very large, broad and closely laid; vines grow rapidly. 40c each; 3 for $\$ \mathbf{\$ 1 . 0 0}$.

HoNEYstCKLE, Japonica Halleana (Hall's Japanese) (F or G), Flowers white, changing to yellow. 35e each; 3 for $90 \mathrm{c}$.

MATRMIONX VINE (I). Handsome trailing vine, covered with scarlet fruit in autumn. 35 c each; 3 for 90 c.

TRUMPET VINE (G). Very hardy and rapid grower. Used for covering unsightly places, stumps, or wherever a showy flowering vine is desired. Produces clusters of trumpet-shaped, orange-scarlet flowers about 3 inches long. If tops are kept cut back it makes a beautiful bush for the lawn. 25c each;

IISTARIA, Chinese Purple (G or I). Strong. rapid grower, desirable for trellises, porches, etc. The light purple flowers are very showy, and are produced in long racemes. A large vine in bloom is a beautiful sight. Perfectly hardy, 50c each; 3 for \$1.25. 


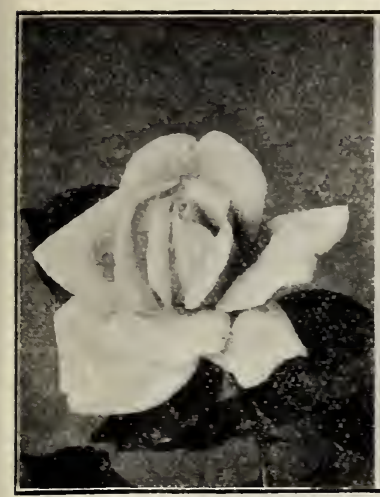

Mrs. A. K. Warldell

\section{Burgess' Select Roses}

house, for in most select rarieties of Roses. Our roses are grown in the greenof buding

and make more satisfoc

roots. Place your Rose order with an

\section{Everblooming Hybrid Austrian Brier Roses}

These three new Hybrid Austrian Brier Roses have created a sensation, taking highest awards here and abroad. The growth is exceptionally strong, throwing numerous sturdy blooming continually from early summer until fall.

LOS ANGELES. Bright pink. tinged with rcd and shading to rich yellow at the base. First size plants, i5c; 2 year, s? 00 , postpaid.

MADAME EDOCARD HERRIOT. Buds vivid orange-scarlet, opening to large flowers of light copper-red, paling to strawberry-pink with age. First size pants, ijc; 2 year, $\$ 2.00$, postpaid.

SOCVENIR DE CLACDICS PERNET. Yellow throughout at all stages from exquisite bud to full open flower. The only everblooming pure yellow rose. First size quisite bud to full open flower.
plants, ioc; 2 year, $\$ 2.00$, postpaid.

\section{Hardy Everblooming Hybrid-Tea Roses}

Thase roses are the result of crossing the tender everblooming Tea Roses with the hardy Hybrid Perpetuals or "June Roses." These roses are hardy and of vigorous growth. but should be given winter protection in the Northern States. They have the size of flower and exquisite fragrance of the "June Rose." combined with the corstant blooming qualities, delicate tints and rich bright colors of the "Taa" or Monthly Blooming Roses. In other words, they inherit the good points of both the Teas and Hybrid
Perp?tuals, and bloom continually from the beginning of summer until fall frosts s Perpituals, and bloom continually from the beginning of summer until fall frosts
in. Both our first size one-year and our two-ycar old plants, set out this spring, bloom this the

ATGCSTA VICTORIA. Pure white, lightly tinted with lemon toward the center. BESSIE BROWY. Creamy-white, flushed and ting d with pink. COLCMBIA. Deep peach pink, deepening into a glowing pink. Magnificent blossoms, often measuring six inches across; fra
less. First size, $40 \mathrm{c} ; 2$ vear, $\$ 1.00$, postpaid.

DUCHES OF WELLIXGTON. Soft golden yellow, veined and suffused with coppe nd $\mathrm{r}$ d. First size, 50c; 2 rear, $\$ 1.00$, postpaid.

ETOHE DE FRA.CE. Rich, velw ty crimson; flowers extremely large; long stems. FRAXCIS SCOTT KEX. Rich glowing scarlet with darker shadings; nothing finer. GENERAL MC ARTRCR. Bright scarlet-crimson. First size, 35c; 2 rear, i5c. HADLEX. Deep relvety crimson, retaining its brilliancy at all seasons of the year. First size, 35c: 2 rear, i5e, postpaid.
HOOSIER BEA sear, $75 \mathrm{c}$, postpaid.

IRISH FIREFI.AIE. Old gold, coppery-yellow or deep maddery-orangs flamed with ruddy crimson, the intense and varying color graduations spontaneously conveying the impression of a flame of fire.

JONKEER J. L. MOCK (Giant La France). Long, pointed buds and very touble, full flowers of deep imperial pinl:; one of the largest Everbloomers. KILLARNEY. Brilliant, sparkling pink; wax-like petals with silvery edges. MADAWE BLTTERFLY. Bright pink suffused with apricot and gold. First size, 50c; 2 vear, $\$ 1.00$, postpaid.

MRS. A.ARON WARD. Coppery orange in the bud, developing to golden-orange in the open flower. First size, 35c; 2 year, 750 , postpaid.

MRS. A. R. WADNELL. Buds of rosy-scarlet, opening coppery-salmon. OPHELIA. Brilliant salmon-flesh shaded with rose, with a heart of glowingpeach-pink. First size, 35c; 2 year, 750 , postpaid.

RADIAYCE. Carmine-rose with opal and coppery reflections.

RED RADIANCE. A magnificent shade of cerise-red; does not fade. SCNBCRST. Orange-copper and goiden yellow: extremely brilliant.

WHITE KULIARNEX. One of the most exquisite pure white roses.

PRICES All Roses in this catalog, except where otherwise noted, first postpaid. See page 67 for SPECLIL DISCOLIT on orders for four or more Rose plants.

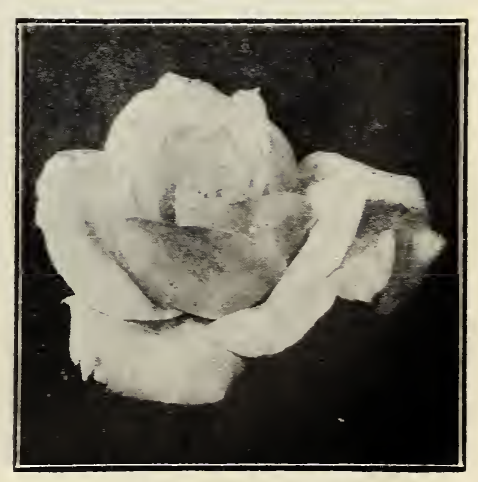

Madame Butterfly

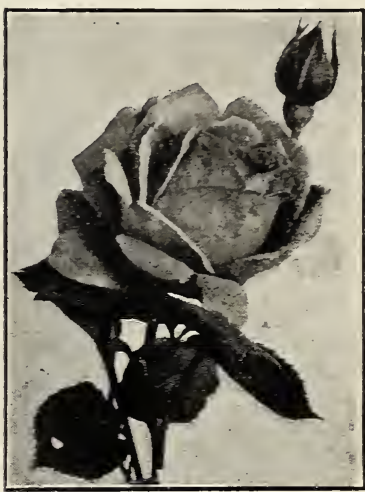

Red Radiance

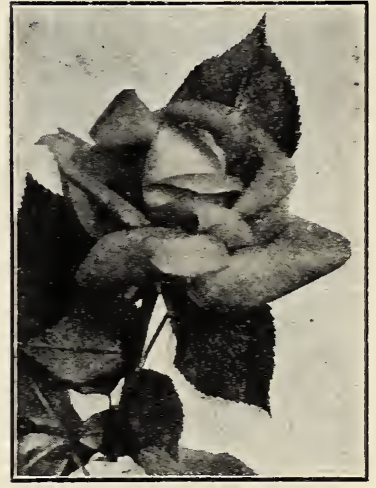

Etoile de France

Buttertiv 


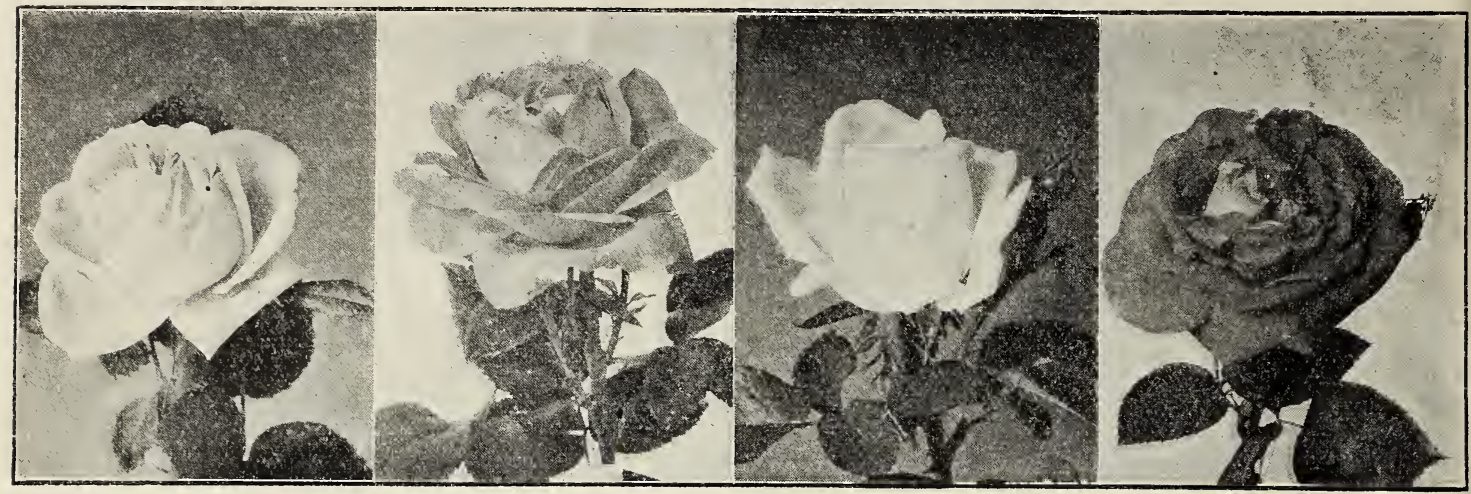

Jrs, John Laing

\section{Hybrid Perpetual Roses}

The Hybrid Perpetuals are hardier than the Hybrid Teas, and require but little care after once planted. Perhaps the most valuible of all hardy bushes for permanent pianting, people living in the Northern States think they cannot grow grown in ¿ny ciimate, provided the right kinds are planted. out the summer months.

AuERICAN BEACTY. The famous rich glowing crimon Rose. First size plants, 40 c each; 2 year, 8jc, postpaid. ANXA DE UIESBACH. A lovely shell pink; long pointec. buds, flowers very full and double; sweetly fragrant.

CAPTAIX CHRISTY. Delicate flesh-pink, deepening at center to rosy-crimson; aimost everblooming.

CAPTAIX HAYWARD. Bright, glowing scarlet.

GENERAL JACQUEMINOT. Brilliant, velvety crimson.

GLOIRE LYONNAISE. Rich creamy white, passing to

salmon-yellow, As iree blooming as a Hybrid Tea.

\section{Eskimo Beauties, the Hardiest of all Roses}

These Roses grow where no others will. They were produced by crossing the hardy $R$ ugosa Rose with the best of the double, everbiooming varieties. Esirimo Beauties grow, thrive and bloom anywhere. They are ideal cold climate Roses. They will grow in the South and in the Middle West; they will stand the winters of Minnesota, Wisconsin and the Dakotas without protection. In hariiness and vigor they are kindred to the Fir and Spruce. They make dense, sturdy, compact bushes, 4 to 6 feet high, and of about the same brealith. and are very ornamental. Once planted, they are permanent, no pruning or spraying; do well in the most trying places-seashore, mountains or anywhere. On account of the shapeliness of their growth and freedom from insects and disease, these Roses are especially valuable for use as lawn specimens, and will last for years and yild an abunclance of large double, fragrant, colorful blooms. Most lependable Roses inr very cold climates. That is why they are called Eslimo Beauties.

CONRAD F. MEYFR. Splendid, large, elegantly formed buls and flowers, $31 / 2$ to 4 inches across, perfectly double.

F. clear silvery-rose, intenseiy fragrant. First size plants, 35c each; 2 year, 70e, postpaid.

F. J. Gright crimson flowers in clusters, resembling First size plants, 70c each; 2 year, $\$ \mathbf{1 . 4 0}$, postpaíd.

NEW CENTCRY. Beautî́ul rosy-pink, in clusters of large, full and double flowers. First size plants, 3äe each. ;0e, postpaid. est double white Rose in its class; beautiful and constant in bloom. First size plants. 35c each; 2 year, j0c, jost paid.

\section{Hardy Polyantha or Baby Roses}

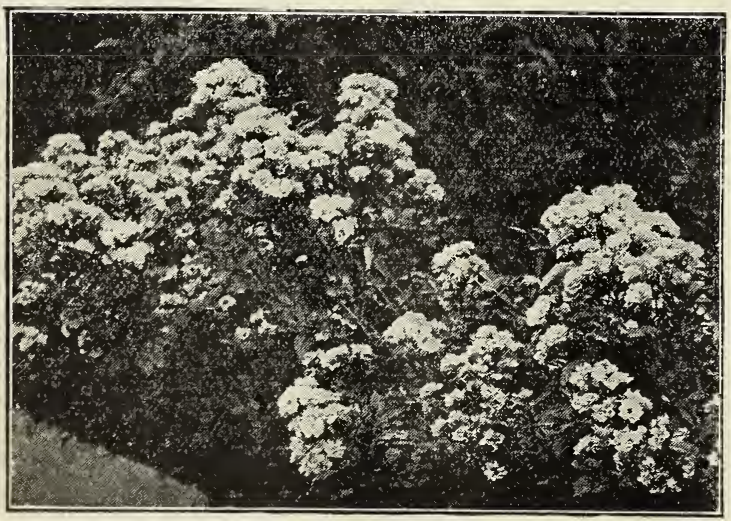

\section{Bloom from June until Frost}

Border your flower beds or garden walls with these delightful Roses and have a continuous mass of bloom from early spring until after frosts. The most proíuse bloomers of all Roses. The growth is rapid and symmetrical, although dwarf, which makes a most desirable combination for edgings and borders and are unsurpassed for cenietery planting. Being periectly hariy, low in growth and continuous bloomers, they are taking the place of Geraniuns to stay and increase in beauty yearly.

CHATILLON. Silvery crimson with whitish center.

ELLEN POLLSEY. Dark, brilliant pink; sweet-scent

GEO. FLGER (Yellow Baby). Dainty, clear yellow.

IDEAL. The brightest red Baby Rose.

KATHERINE ZEOIET (White Baby). Pure white.

ORLEAXs. Brilliant geranium-red, suffused rose. 


\section{Choice Tea Roses}

While not so lardy as the Ifybril Teas, they will. with protection, live through the winter ever:where except in the extreme forth. In the South they are unexcelied, whether planted in the open ground or used for pot culture. The fact that one year oid piants produce a profusion of flowers malies them indispensable to every rose lover.

ALEX.NDLR HILL GRil. The finest lemon yellow Tea Rose; does not fade; hardy. Awarded Gold Medal by the National Rose Society.

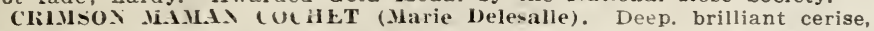
reverse of potuls slicked carmine; long shapely bucls with large petals.

L.ADY HILLINGDON. Deep apricot-yellow, shading to deep orange Gold Medal Xialiona l.ese society.

PINI MAMAX COCHFT. The best Pink Tea Rose. Hardy everywhere. WHITE MAMAN COCHET. The best white Tea Rose. Vigorous as an oak and hardy evervwhere.

W1LLIAM IR. SMIt. Flowers immense in size, deep, double and grandly formed: rose tiuts in the center of the flower, gradually shading into pale blush creamy-white. producing a color effect found in no other rose.

\section{Hardy Moss Roses}

CRIMSON GLOBE. Deen crimson. large and full; nicely mossed. MOCSSELINE. Very large: double: pure white. PRIXCESS ADFLAITE. Large: double; deop pin

\section{Gruss an Teplitz, ( The Creat Hybrid $)$}

roses for the lawn. Grows freely to a height of 4 or 5 feet: hardy in all sections: vivid. dazzling, fiery crimson; sweetly iragrant; and is in bloom all the time.

\section{Hardy Climbing Roses}

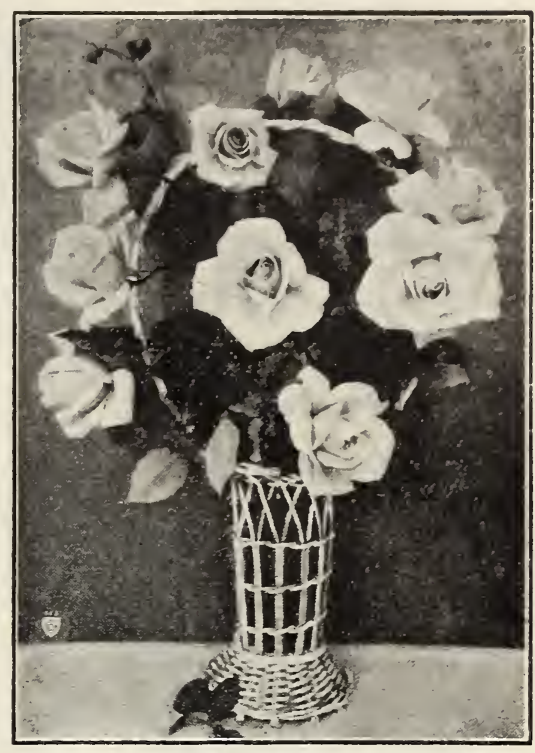

Tea Roses
These Roses aro necessary for the home. giving it a touch of beauty and calling forth more admiration than any other ormamental plants. They are used extensively for screening undesirable views of buildings and create most delighttul and refreshing shade when used on porches, verandas, pillars and fences. All are hardy everywhere and require very little care and attention to produce an aniazing profusion of exquisite hued blossoms.

ALIDA LOVETT. Bright shell pink with shadings of sulphur-yellow at the base of petals. Similar in size ancl iorm to Dr. Tan Fleet.

BESS LOVETT. Clear, bright crimson, double, and of notable lasting quality. Resembles Climoing Americau Beauty, but is brighter in color and more fragrant.

CLIMBING AMERICAY BEATTY. A sturdy. vigorous grower. absolutely hardy, throwing strong flowering canes in one season which are corered with dark. glossy foliage that is immune to disease and insects. The Rose are 3 to 4 inches in diameter, are produced on individual stems, vivid rosy-crimson in color, and with the sam deliciuus fragrance as the old American Bauty.

DR. TAN FLEFT. I,arge, double flower diameter, borlle on lung strong stems; delicate flesh pink, deepening to rosv-liesin in the center.

MARY LOVETT. The finest of all absolutely hardy white climbing roses. Could be appropriately described as a pure white Dr. Tan Fleet.

A Dr. Van Fleet production; clear ose pink with salmon at base of petals.

PACL'S SCARLET CLMBBER. Expert rose growers agree that this is the best and most valuable climbing red rose for home planting. The full, double, scarlet flowers cover

\section{Most Desirable $\$ 4.12$
Everblooming Roses $\$ 4.12$}

The memions of the Amorican Pose Sciety roted the tollowing as being the twelve most desirable
Everblooming Roses: Radiance, Ophelia. Red Radiance, Iuchess of Wellington, Los Angeles, Madame Butterfl. General McArtlur, Gruss an Teplitz, Columbia. Madane Edouard Herriot, Augusta Victoria and Irs. Aaron Ward.

This entire collection of twelve first size plants, if purchased singly, would cost you $\$ 5.15$; or $\$ 11.85$ in tlie 2 year size. By taking advantage of the $2 \mathrm{C}:$ discount we allow on orders for twelve or more, this entire collection in the first size would cost you only $\$ 4.12$; in the 2 year. $\$ 9.48$. If you would increase the order to twenty Rose plants. the discount would be the bottom of this nage.

\section{Rambler Roses}

You surely have a place for some of this class of climbing Poses. You can use them on porches, arbors, arches, pergolas. cloth.s-posts. iences and old stumps of trees. Hardy everywhere.

BLCE R.MBLER. Flowers rosy-lilac when opening and change to a metallic blue. Tery slowy.

DOROTHY PERIIIs. The finest of all pink ramblers. Flowers perfectly double and borne in immense ciusters.

RED DOFOTHY PERIIIS (Excelsa). The most popular red rambler. Flowers in large clusters of rich scarlet.

WHTE DOROTHY. A pure white sport of the well WHITE DOROTHI.
known Dorothy Perkins.
YELLOW RAMBLE:. A grand variety, quite similar to old Crimson Rambler. With the exception of color. kich yellow flowers, borne in large clusters; blooms prousely, and is as hardy as an oak.

TAUSENDSCHOEX (Thousand Beauties). A climbing Rose which produces on the same plant so many different colored flowers that it is impossible to describe the variations, hence the fitting name, "Thousand Beauties." Biooms profusely during June and Julv: double flowers in large cfusters. The colors run from tender rose through the intermediate shades of bright rose and carmine, with white and yellow tints showing. PRICES All Roses in this catalog. except where otherwise noted, first size one-rear plants, 30c each; two-
year o'd planis, 65e each. postpaid.

SPECIAL DISCOCNTS. $10 \%$ discount if you order 4 Rose plants; $15 \%$ if you order $8 ; 20 \%$ discount on 12 ; $30 \%$ on 20 or more. All must be shipped to one address in order to get these discounts. Take your choice of rarieties. You may assort your order to please yourself, and each plant will go to you prepaid and properly labeled as to variety: 


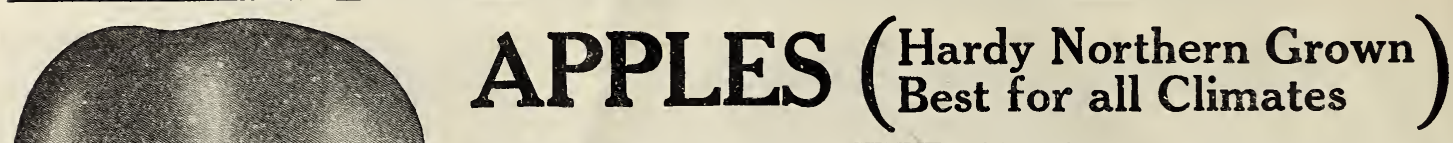
SCMNER APPLES

DUCHESS OF OLDENBCRG. Good size, pale yellow, streaked red; juicy, sour highiy esteemed tor hume use or market. Good crop when trees are 4 or 5 years old.

MARLY MARVEST. Fruit of medium size; bright straw color when fully ripe. Flesh of excellent quality; tender, crisp and juicy.

RED ASTRACHAx. Most attractive early red apple. Flesh white, crisp and juicy, with a pleasant acid flavor. One of the best early eating apples.

YELIOW TRANSPARENT. The earliest apple to bear; good crop when trees are four to five years of age. Skin pale yellow. Flesh white, crisp, juicy, mildly sub-acid. An excellent eating and cooking apple.

\section{FALL APPLES}

FAIT PIPPIN. Large, yellow, rich, aromatic. Fine eating apple and especially good for cooking.

IAIDEN BLUSH. Yellow with red cheek. Fruit medium to large; juicy, pleasintly sub-acid. Excellent for culinary use.

RAMBO. Medium; yellow, streaked red. Fine apple that does well nearly everywhere.

SNow APPLE (Famense). Red skin, white flesh; juicy, mild, spicy and very tender.

WFAYTHy, Rich dark red. Medium to large. Flesh white, sometimes stained with red. Fine grained, tender, juicy and of excellent quality. Trees mature early; bear when 4 years old and large crops every year.

\section{WTITER APPLES}

BALDWTy. Yellowish red, heavily shaded with deep red. Large, splendid keeper, guod cooiser, and one of the most popular varieties.

DEICiOUS. Large; nearly covered with brilliant dark red. Flesh fine grained, nder and flowing, over with rich, highly flavored juice. A splendid keeper. Tree matures early: unusually productive.

Gros GOLDEN. Rich, golden yellow skin, mild sub-acid flavor, tender and Grum

JoxATHA., Medium size, bright red apple; tender, crisp, very juicy, with a

MeIntosh

fine flavor. Cum into bearing rather young.
MerNTosf. Medium size, deep crimson, highest quality, juicy, sour. Comes into MeINTOSH. Medium
bearing ratier young.

YORTHERY SPY. Large, red striped, juicy, mild sub-acid, with a rich, delicious flavor. Extra long keeper. None better for cooking or eating out of hand.

NORTHWESTERY GREENTYG. Hardy, yellow, rich, of good size; an extra long ketper, which makes it a stand-by to finish the winter for cooking purposes. RHODE ISLAND GRIEENING. Large, greenish-yellow, juicy, with a rich acid flavor. Good keeper. One of the best cooking apples.

ROX RUSSET. The most popular russet apple; russet-brown skin; a remarisable keeper, commanding good prices in the spring.

STAYMAY WNESAP. Large; deep red skin; juicy, sour, pleasing flavor. An excellent keeper.

TOLMAN SW"Ex. Best sweet. Yellow, medium to large. Comes into bearing moderately young.

WTNTER BANANA. Large; clear pale yellow with beautiful pinkish red blush. Good dessert quality, but too mild to excel for culinary uses. Comes into bearing young.

HYsLor. Brilliant dark red overspread with thick blue bloom. The best and most reliable crab apple.

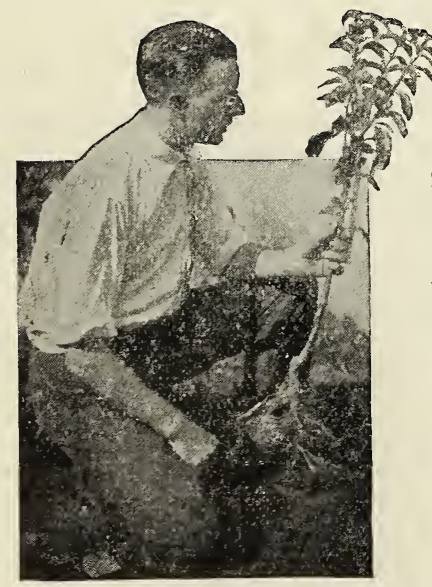

\section{SPECIAL OFFER}

\section{ONE-YEAR-OLD APPLE TREES}

We have severai thousand one-year apple trees of the following varieties: GRMIES GOLUEN. These are four of the most popular varieties of apples. the most popular varieties of apples. of 2-year old stock, we are sure these trees will please you. This is a bargain in clean, hralthy, Northern grown apple trees which you will profit by taking advantage of, and you will do well to place your order before this stock is all sold. These trees run from 2 to 3 feet in height, averaging one foot taller than those listed in the special offer on our catalog envelope. Order only Delicious, Jonathan, MrIntosh and Grimes Golden in this size. Trees sent by express, not prepaid, at these prices.

\section{6 for $\$ 1.00$}

25 for $\$ 3.50 ; 50$ for $\$ 6.00 ; 100$ for $\$ 11.00$

\section{Prices of Apple Trees}

We can supply all varieties of Apples listed in this catalog, in thrifty 2-year-old Northern grown stock, 4 to 6 feet in height, heavily branched, and too large to send by parcel post. These trees are shipped by express, not prepaid. Select the varieties you want at the following low prices: 75e each; 3 for \$2.00; 5 for $\$ 3.00 ; 10$ or more at $50 \mathrm{c}$ each; 20 or more at $45 \mathrm{c}$ each; or in lots of 50 or more at 35e each.

\section{DWARF APPLES}

Dwarf apple tres come into bearing much earlier than the standard trees, and are very productive. Their low, broad heads are within reach, so that the fruit call be easily picked. These trees are set 8 to 10 feet apart and take up so little room that they can be planted in the garden, or even on the lawn. and, with care, usually commence to bear the second year after planting, and will bear good crops within three or four years. Our dwarf trees bear large, full-sized fruit the same as standard trees.

We have only the following list of best varieties of Dwarf Apples to offer: Delicious, Jonathan, MeIntosh, Northern Spy, Yellow Transparent.

PRICES OF DWARF APPLE TREES, by express, not prepaid: 75e each; 3 for $\$ 2.00$; 5 for $\$ 3.00$; 10 or more at $50 \mathrm{c}$ each. 


\section{PEACHES}

We have picked out what we consider to be the best eight varieties of Peaches-those that have proven tlwir worth uncier the most unfavorable conditions and in all suils and climates. If you will limit your planting to these varietics you will be making no mistake.

BEILE OF GEORGIA. Tery large. white fleshed with red cheek; firm. juicy and excellent flavor. Very hardy and grows with equal succss in both North and south. Productive; early: stone semi-free to free. The most b autiful white peach grown.

CARMAX. One of the Carman's greatest assets is its rugged constitution which enables it to withstand trying climates, and to accommodate itself to a great variety of soils. Flesh white, rat the pit, juicy, rich and sweet. Stone nearly free. Early.

CRATFORD LATE. A grand, large, yellow freestone. One of the best late varieties.

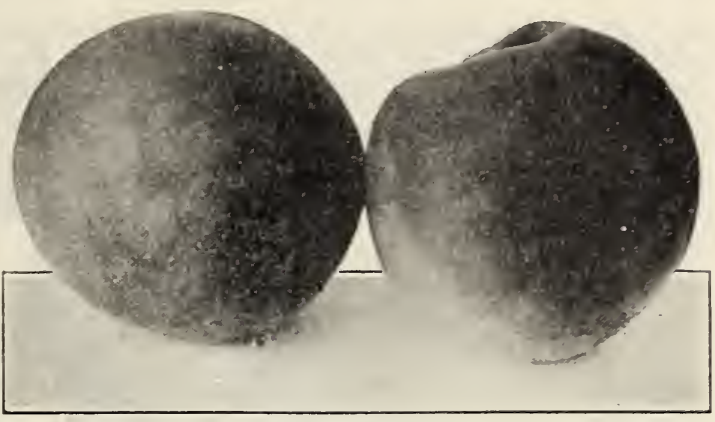

Elberta Peaches

ELBERT. The most popular peach grown. Large. yellow with red cheek: flesh yellow, firm, juicy. highly flaored, ricli and sweet; exceedingly prolific, sure bearer and hardy. An ideal mid-season variety. Freestone.

HALE. Beautiful golden yellow overlaid with bright carm:ne: larger than Elberta and ripens a week earlier. Gnod shipper and ketper, and on the market it commands the highest price. Freestune.

T.ALAMAZOO. A beautiful peach that will boar good crops of fruit when all other varieties fail. The surest cropnor f them all. and very hardy. Large, golden yellow with crimson cheek; yellow llesh, superb quality, small pit. Midseason. Freestone.

I.EYON FREE. Lemon-shaped and colored, large size, f-oestone immensely productive excellent quality One of thi best commercial peaches and the most popular lor cann.ng. Late.

ROCHFATER. In a class by itself because it is tho only gonr sized yellow freestone peach of fine quality ready for market from the 1ith to the middle of August in th. Northern states. Large, yellow with a most attractive red blush. juicy, delicivis inti leeps will. strong grower, good bearer and very hardy.

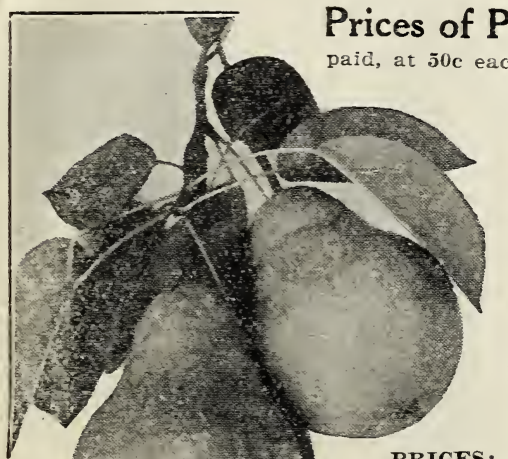

each Trees ist lived and the bsst for ail climates. By express, not pren lots of 50 or more at $25 \mathrm{c}$ each. Idaho, Oregon, Washington and Canada.

\section{PEARS}

BAITLETT. Popular everymere. Large, yellow, juicy pear. September.

CLAPP'S FAVORITE. Large; juicy, splendid flavor. August.

FLEMISH BFALTY. Large. juicy and melting. rich. sweet and excellent flavor. September and October.

KIEFFER. Its large size, handsome appearance and remarkable keeping and shipping qualities make it very profitable for market. Cotober and Norember.

SEFEL. Small, juicy, melting, tender. Fine for preserving and pickling. September and October.

PRICES: Large 4 to 6 feet trees. by express. not prepaid. at 85 e each; 3 for \$2.25; 5 for $\$ 3.50 ; 10$ or more at $65 \mathrm{c}$ each; 20 or more at $60 \mathrm{c}$ each; or 50 or more at $50 \mathrm{c} \in \mathrm{acl}$.

\section{Dwarf Pears}

The cultivation of Dwarf Pears is vert profitable. The trees are low-headed and come inco bearing usually the second or third year. Our dwarf trees bear large. full-sized fruit the same as standard trees. but a greater number can be planted in a given space and the crop is more easily gathered. There are very few of our customers who cannot find room ior a few dwarf trees in the garden, on the lawn or as a hedge. Pears are dwarfed by budding on quince roots. and the trees should be planted 3 inches below the union. We can supply only Bartlett and Clapp's Farorite in the dwarf trees. By express, not prepaid. 85e each; 3 for $\$ 2.25$; 5 for $\$ 3.50 ; 10$ or mure at túc each.

\section{SWEET CHERRIES}

BING. FeT sweet cherries equal Bing in size, attractireness and ouality Large; delicious: bears early and abundant.

BLACK TARTARIAX. A popular home garden sweet cherry; purplish-black; flesh tender, juicy and rich. Produces immense crops. Pipens earlier than Bing. GOVERYOR WOOD. Light yellow, marbled with red; very large; juics, rich and delicious. Exira ear

LAMBERT. A very sweet variety and one of the largest. Dark purplish red, turning almost jet b'ack when rive. Laier tlian Iing.

I.APOLEON. Fellow with bright red cheek; very large, meaty and sweet. Tery productive; bears joung.

PRICFS Large 4 to 6 feet trees, by express, not prepaid, at $\mathbf{8 1 . 0 0}$ each; 3 for or 5.75: 5 for \$4.25; 10 or more at 80c each; 20 or more at ise each;

\section{SOUR CHERRIES}

EARIY RICHMOND. A dependable variety which seldom misses a crop. Dark red. Best early sour cherry.

LARGE MONTMOREXCY. Large red cherry; larger than Early Richmond and fully ten days later. The leading commercial variets.

ENGLISH MORELLO. The standard late sour cherry. Very dark red, aimost black; excellent quality. A month later than Montmorency.

PRICFS Large 4 to 6 feet trees, by express, not prepaid, at 85c each; 3 for \$2.25; 5 for $\$ 3.50$; 10 or more at $65 \mathrm{c}$ each; 20 or more at $60 \mathrm{c}$ each: or 50 or more at $50 \mathrm{c}$ each.

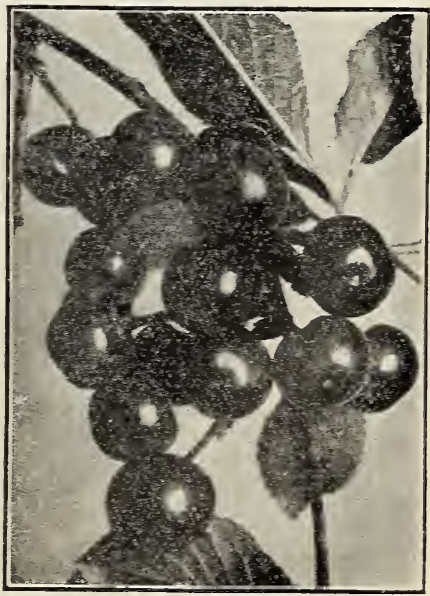

Bing Cherries 


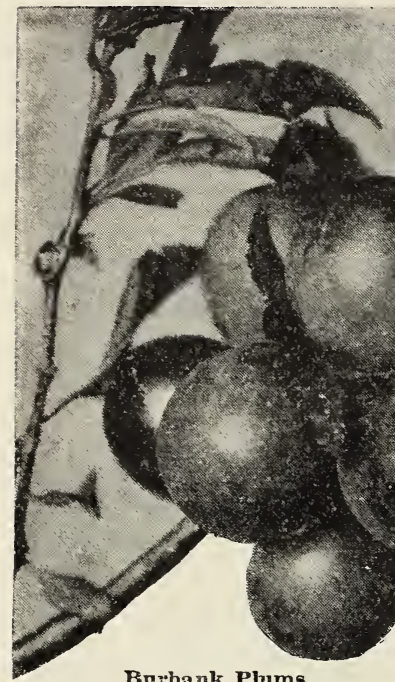

Barbank Plums

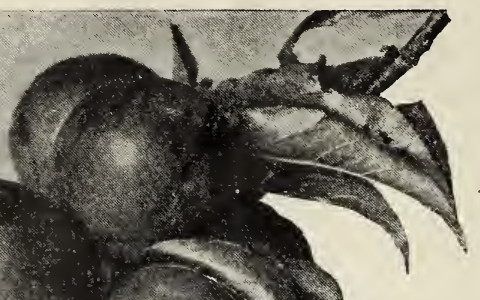

\section{PLUMS}

ABCNDANCE (Japan). Large, red, sweet, very juicy, tender and melting. Early.

BURBANK (Japan). Skin dark red over a yellow ground; juicy sweet. Good shipper; ripens a week later than Abundance. Large.

GERMAN PRTNE. Purplish-black, medium juicy, large. Good market variety; one of the most popular for canning, because of its sweetness.

IMPERIAL GAGE. Large, pale green, juicy, sweet, rich and excellent. Very popular.

LOMBARD. Medium size, red, juicy and sweet. Will grow anywhere and should be in every garden.

PRICES Large 4 to 6 feet trees. by express, not pre10 or more at 5aid, at $\mathbf{5 5 c}$ each; 3 for $\$ 2.00 ; 5$ for $\$ \mathbf{\$ 3 . 0 0}$; more at $40 \mathrm{c}$ each.

\section{QUINCE}

ORANGE. Fruit large, bright yellow, of excellent flavor; the best Quince for all sections of the country. Unsurpassed for preserves and jellies. Both fruit and flowers are quite fragrant, and the trees and bloom highly ornamental. Large plants, $75 c$ each; 3 for $\$ 2.00$; 5 for $\$ 3.00$; or 10 or more at 50 c each, by express, not prepaid.

\section{The Big Money Maker}

\section{$\$ 1000.00$ a Year per Acre with Lucretia Dewberries}

Dewberries are bringing big money and we are advising our customers to get started with them as soon as possible.

Lucretia Dewberries are larger than any blackberry, sweeter and milder in flavor, and of excellent quality for home use or market. They ripen a week or ten days ahead of common blacliberries, the bulk of the crop being harvested before otler blackberries start to ripen, so sell at very high prices.

The Dewberry belongs to the blackberry family, and the Lucretia is the best of them all. The large berries are incomparably better than any blackberry grown; of unequaled excellence; sweet and luscious throughout, and of bright glossy hlack color. They are very productive and the most profitable of all fruit crops to grow. The Lucretia has received the highest endorsement aud lighest praise from the best horticulturists in the country. Its trailing habit renders it less liable to winterkill. Propagates from the tips, like black raspb-rries; dous not spread or sucker.

There are two methods of growing the Dewberry. One is to set the plants 4 feet apart in the row, with rows 6 to 7 feet apart. Allow thein to grow along the row in their natural way, removing all the new growth until arter blooming time, and then allow only enough $\mathrm{n}$ w vines to grow to provide for the next crop, and at the same time shade the ripening fruit. In this way they will ripen earlier than they would tied up to wires or stakes, the whole crop being grown in Nature's own way down among the dewy leaves unexposed to strong rays of summar sun. Cortrolling the new growth each season does away with the necessity of stali $s$ or posts and wire.

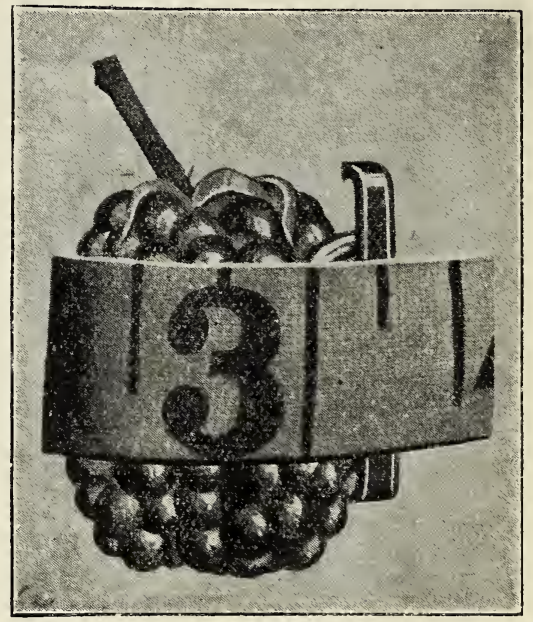

Lucretia Dewberry

The other method of growing is to use short posts and wire. Grown in this way, the fruit is much easier to pick, but is not quite as early. The posts need be only 30 to 36 inches high. Use one wire and in the spring tie all canes onto same. holding them off the ground. Let the new canes lie on the ground throughout the growing season, covering them slightly for winter protection in climates where the winters ar severe. Cut away old wood in spring and tie new canes on wire, or old wood can be removed soon after harvesting the crop.

We absolutely guarantee our plants to be the genuine large fruited Lucretia. About 1,700 plants are required to set an acre.

PRICES: 6 for 65e: 12 for $\$ 1.00 ; 25$ for $\$ 1.75$ : 50 for $\$ 3.00 ; 100$ for \$5.50. by parcel post, postpaid. By express, not prepaid, $\$ 4.00$ per $100 ; \$ 8.00$ per $250 ;$ or $\$ 26.00$ per 1,000 in lots of 500 or more.

\section{Family Orchard "Our Choice" 8 Varieties \\ $\$ 5.00$}

Three Apple Trees (one each of Summer, Fall and Winter varieties), 1 Peach, 1 Pear, 1 Plum, 1 Sour Cherry and 1 Sweet Cherry-all large 2-year old trees-these eight trees. our choice of varieties, by express, not pr.paid, for un!

\section{Family Berry Garden "Our Choice" 100 Plants

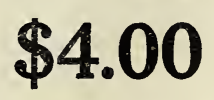

50 Strawberry, 12 Red Raspberry, 12 Black Raspberry, 12 Dewberry, 12 Blackberry and 2 Grape plants-100 plants in all-our choice of varieties, by parcel post. postpaid, for only $\$ \mathbf{4 . 0 0}$. 


\section{Victory Raspberry}

\section{The Bisgest Money Maker of all Red Raspberries}

\section{Oe all Pod Paspborries gromp. rictort takes a lons lead in nronuctivenese} and size of fruit. To give you an idea of the trementuus size of its crops. it has produced neariy wice as much fruit as Cuthbert. Tictory originated in Northern Jichigan and has withstood 30 degrees below zero withou of the characteristics of that grand old variety. We have discontinued the way. It is by far the best quality of any Red Raspberry, and mammoth in markable degree immune to all viant disesses. Tnequalled as a main

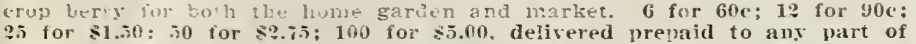
the Inited tates. Ry exprss, nut prejaid, $\$ 4.60$ per $100 ; \$ 8.00$ per 250; or $\$ 30.00$ per 1,000 in lots of 500 or more.

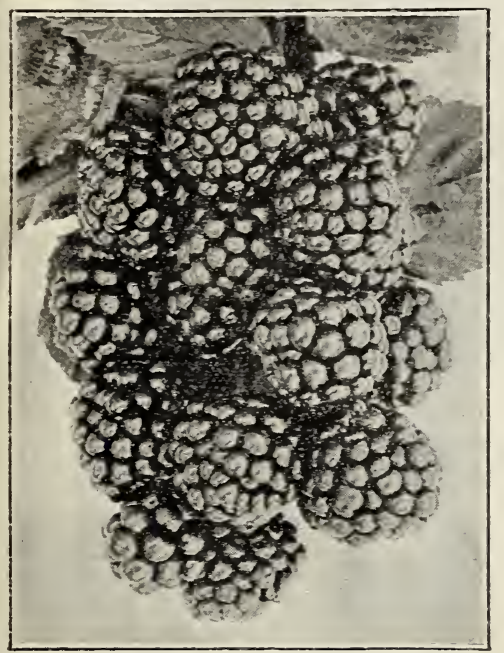

Eldorado Blackberrs

EARIT KING (red). The red raspberry. Growers all over the country are discarding other rarieties. owing to the big profits that can be made grotring the King. Extreme hardiness, Earliness, productireress. exceland bright co:or which holds until placed on the most distant market, together with the lact ous growers and remarkably free from disease. make it the most profitable early red raspberry to

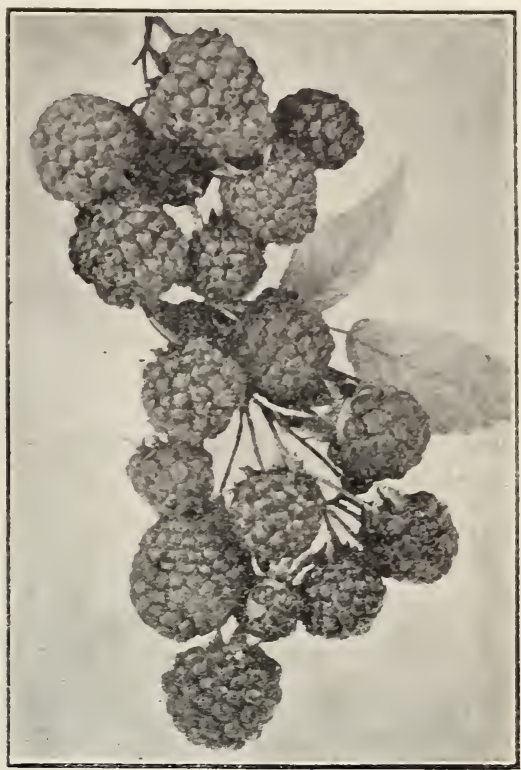

St. Regis Everbearilig

6 for 55c: 12 tor $85 x$; 25 for $\$ 1.45 ; 50$ for \$2.65; 100 for $\$ 4.75$, by parcel per 1,000 in lots of 500 or more.

ST. RFGIS EVERBEARING (red).

summer and fall, and until the berrie

As to quality of fruit. St. Regis has
large size, rich. sugary. and of the best

the canes enduring the sererest cold uning protinc. The near the ground, late in the fall. prevents the summer crop and has a tendency to make the fall crop more abundant. 6 for $60 \mathrm{e}$; 1 ? for $90 \mathrm{c} ; 25$ for \$2.i5: 100 for \$5.00 postlaid. Br evvress. not prepaid. $\$ 4,00$ CTMBERLAND (black).

Very hardy, and the most profitable market sort. Prices same as St. Regis. COLCMBIAN (purple). A cross between a black and red raspberry, the result of which is a purple berry. Do not sucker or spread from the roots like red varieties. This malies it a most desirable sort for the home garden. Berries large, rich and juicy, and better than red or black raspberries for canning. 6 for ijc; 12 for $\$ 1.25 ; 25$ for $\$ 2.00$; 50 for $33.55 ; 100$ for $\$ 7.00$, postpaid. By express, not prepald. $\$ 6.00$ per $100 ; \$ 12.00$ per 250 ; or $\$ 45.00$ per 1,000 in lots of 500 or more.

GOLDEX QTEEX (yellow). A beautiful, large, golden reliow raspberry. Many prefer this variety to any of the red or black sorts, owing to its sugary sweetness and unsurpassed flaror. Should be in every garden, its beauty and high quality placing it at the head for table use. The canes are hardy. of strongest for \$2.15: 50 for $\$ 5.00 ; 100$ for $\$ 9.00$, postpaid. By express, not prepaid, $\$ 8.00$ per 100 .

\section{Blackberries}

ELDORADO. The recommend this rariety ahead of all others. The berries are large in size, very sweet, and of delicious flavor and quality. It is one of the hardiest blackberries in cultivation and has never been known to winterkill. Tery productire, and never fails to ripen a crop. 6 for $65 \mathrm{c} ; 12$ for $\$ 1.00 ; 25$ for $\$ 1.75$; 50 for $\$ 3.00 ; 100$ for $\$ 5.50$, postpaid. By express, not prepaid, 44.50 per 100 ; $\$ 9.00$ per 250 ; or $\$ 34.00$ per 1,000 in lots of 500 or more.

ICEBERG. This is the white blackberry. It is not merely a curiosity, for in aodition to being a real noveltr it is a berry of extraordinary quality. These shining creamy-mhite berries, when mixed with jet-blach ones, make a most attractive dish. The bushes are good strong growers and very productive. For best results. this variety should be planted near other blackberries. Plants, 20c each; 3 for $50 \mathrm{c} ; 12$ for $\$ 1.50$; 25 for $\$ 2.55$; postpaid.

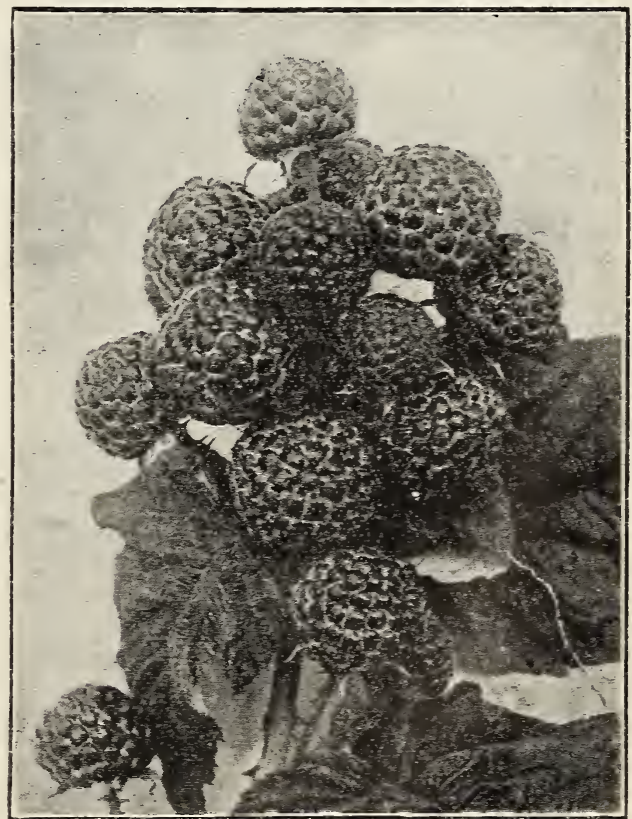

Cumberland Black Raspberry 


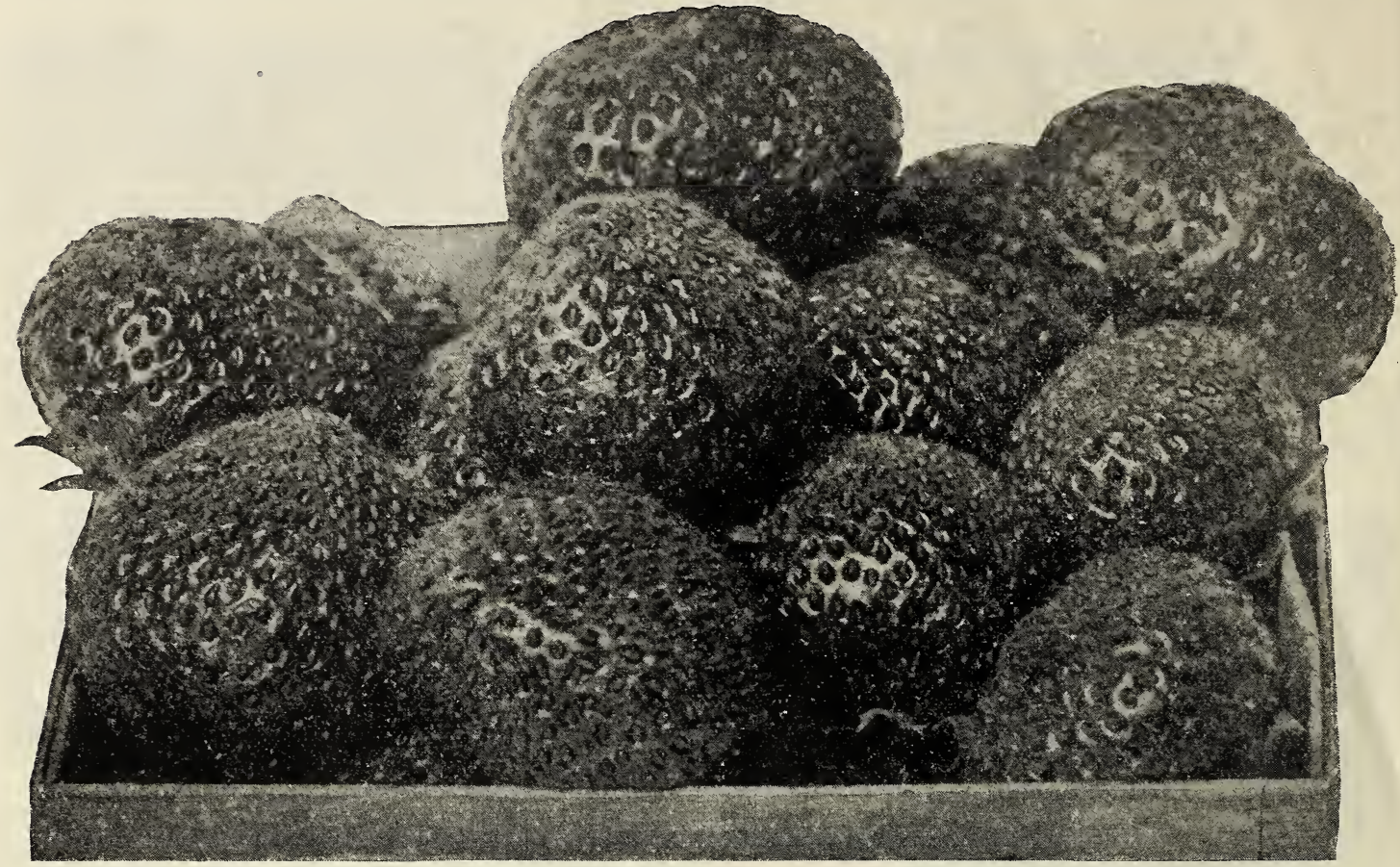

A Box of Number 999 Giant Everbearing Strawberries-Exact Size

\section{NEW GIANT EVERBEARING STRAWBERRY}

This wonderful berry is the resu't of vears of labor in breeding and was selected from eighty thousand seedlings by an experienced strawberry grower who spent the best years of his life in the work of originating and improving the Everbearing Strawberry. Berries of Number 999 Giant are mammoth in size, of ten measuring up to $5 \frac{1}{2}$ inches around. They have a beautiful bright red color and a flavor superior to that of any oth $r$ Everbearing Strawberry.
Number 999 Giant is a strong, vigorous plant; with clean, bright leaves of a peculiar bluish-green tinge, which co or we have found to be a great $h$ at and rust resister. Fields of Number 999 Giants stay bright and clean all through the hot, dry speils wh.n other varieties will rust and burn. It is also a splendid plant maker covering the ground in a single season when set $2 \frac{1 / 2}{2} 4$ feet. The root system grows deep into the ground. reaching from 12 to 15 inches and so
gits into the moist, damp soil, even during a very dry time.

\section{A Big Crop of Berries the Same Season Plants Are Set}

Plants set in the spring will produce a big crop of full size berries during the summer and fall of the same year, and, not only that, but the following spring will produce $\therefore$ nother big crop during the regular strawberry season. Why bother with common strawberries when you can grow this wonderful variety. This is without exception the most valuable variety of Stráwberry ever produced, being of so much better quality than the much advertised Mastodon that there is hardly a comparison. The Mastodons do not sell when the 999 Giant berries are in the market. We are not

\section{The Most Profitable Strawberry to Grow for Market}

The new 999 Giant is the Everbearing Strawberries, but it is the biggest money maker of them all. One grower in Iowa picked at the rate of 22.160 quarts from one acre of ground; another in North Carolina. 19.280 quarts to the acre, and many others report nearly as good as these.

Talking inte consideration the fact that the big bulk of the crop of the 999 Giant Strawberrits comes at a season of the year when berries bring high prices, such crops as these reported would pay the growers better than $\mathbf{\$ 5 , 0 0 0 . 0 0}$ per acre.

\section{Spring or June-Fruiting Strawberries}

To those who wish to purchase piants of varieties which iruit only during the usual Strawberry season, we recommend the three following varieties:

PREMIER. The earliest of all Strawberries; berries of large size, beautiful color and excellent flavor and quality. The most profitable extra-early variety.

COOPER. The iargest berries of any variety we have tried, and produces them in great abundance. A wonderful root system, being the most thrifty Strawberry grown. Unsurpassed for color, appearance, quality and flavor; mediumearly.

AkOMA. We consider this the finest of all the late varieties. Big, round, dark red berries; sweet and of the best eating quality. Brings big profits to growers everywhere.

Plices of Premier, Cooper and Aroma. 25 for $70 \mathrm{c} ; 50$ for $\$ 1.13 ; 100$ for $\$ 2.00$, postpaid. By express, not prepaid, 250 for $\$ 3.00 ; 500$ for $\$ \mathbf{5 0 . 5 0}$; or $\$ \mathbf{1 0 . 0 0}$ per 1,000 .

SPECIAL OFFER 100 plants, 25 each of 999 Giant Everbearing, Premier, Cooper and Aroma, for \$4.00, or only $\$ 10.00$. 


\section{ADCO ARTIFICIAL MANURE}

"t waste garden rubbish. Turn it into manure with ADCO.

ADCO is a powder which, when mixed with aimost any nonmoody regetable waste and kept moist, gradually converts the mass into real manure fully equal to the farmyard product in fertilizing power, but free from foul odor, tlies, weed seeds, etc. The process is perfectly simple and not at all laborious.

50 LBS. OF ADCO MAKES A TON OF MLITRE

Gardeners can now have plenty of manure at low cost and little trouble. Dy utilizing straw, corn stalks, leaves, cuttings, potato. bean secure their manure withou the expense and labor of maintaining lirestock

FOR HOWE GARDEXER An excellent method of treating garden refuse in the small garden is to use a crate. Into this the refuse is emptied das by day, and whenever it becomes an additional foot high it is compacted. Wetted thoroughly, and sprinkled with ADCO

A pound of $A D C O$ is enough for four cubic feet of refuse.

PRICEs: 25 lbs. br express, not prenaid, $\$ 2.00 ; 150$ lbs., by freight, not prepaid, $\$ 10.50$.
Atlas Von-Poisonous Weed Killer Duster Atlas Non-Poisonous Teed Tilertion in cluding poison ivy, Canada Thistle. Johnson grass, etc., without danger of poisoning humans or animals. Simpls shake powder from can on ans undesirable regetation. weeds, grass, etc. Especially recommended tennis courts and gutters.

DTSTER (kills 300 sq. feet weeds), $\$ 1.8$, each,

\section{Spray Plants with}

\section{EVER GREEN}

EFFECTIVF against most all kinds of plant pests, inBeetles, Plant Lice. Cabbag

Worms, Potaio Bugs, Squash Bugs. Red spiders, Rose

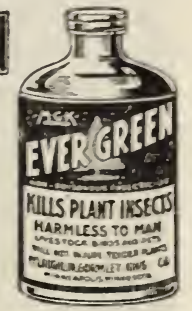
Le a f Hopp

SAFE-K

man, livestocl

Yox-INJTRIOT_Ever

EAST TO TSE-J

ECONOMCAL EVER -

TILL YOT GTI SPRAIERE- To bad $\in$ id cannot clog sprayers.

PRICES: Br parcel post, postpaid, one oz. bottle, $50 \mathrm{c} ; 6 \mathrm{oz} .$. \$1.25; $16 \mathrm{oz}$. \$2.25. By $\$ 3.50$; one ga.10L, \$13.00.

\section{Granulated Peat Moss}

bug ground, under the regetation. The pests eat the destrored. SNAROL will also kill Gophers and Ground Souirreis, if placed in their runways. SNAROL will not deteriorate from rain or sprinkling and is non-injurious to regetation when used according to simple direc-
tions. Should be used in erery garden. large or small. By express, not prepaid: 1-lb. package, 50c; 3-1b. package, \$1.00; 15-1b. package, \$3.75; $50-1 \mathrm{~b}$. bag, $\$ 10.00$.

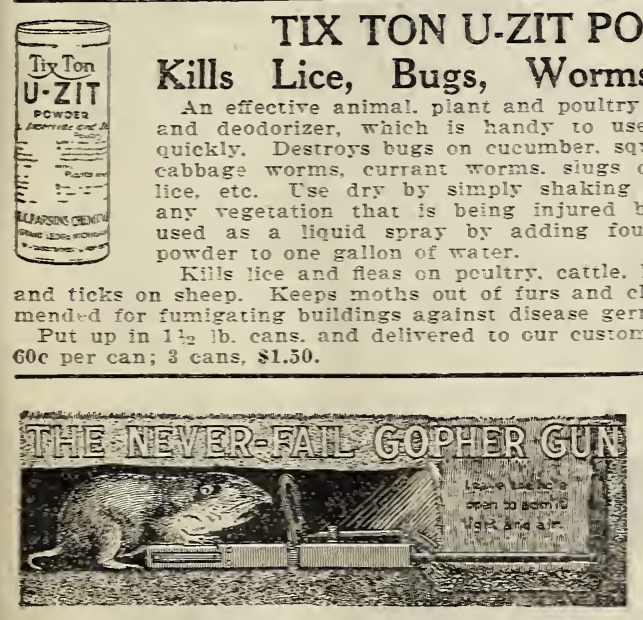

Shoots Blank Cartridges KILLS MOLES Gophers, Rats and all burrowing pests

Load gun with a $35 \mathrm{~s}$. \& $\pi$. Blan' Cartridge as sold by dealers everywhere and set in gopher tunnel. Within a few minutes the gopher will attempt to close the hole, setting off the gun. The concussion kills them evers time. For moles dig down to main run and set same way. It is
guaranteed to give satisfaction and sate rou mant dollars worth of damguaranteed to give satisfaction and sate rou mant dollars worth of dam-
age caused by these underground raiders. It nerer fails. Kills instantly and at a cost of only about one and one-half cents per rodent. One user writes that he killed orer 200 gophers and 30 moles in one. season with two of the Xerer-Fail Gopher Guns. \$2.00 each, postpaid.

PULVERIZED SHEEP MANTRE. One bag equals a whole wagon load of barn rard manure: absolutels no treed seed. BY freight. not prepaid: 100 lbs., $\$ 2.50 ; 500$ Jbs., $\$ 10.50 ; 1,000$ Ibs.. $\$ 20.50 ;$ ton, $\$ 40.00$. 

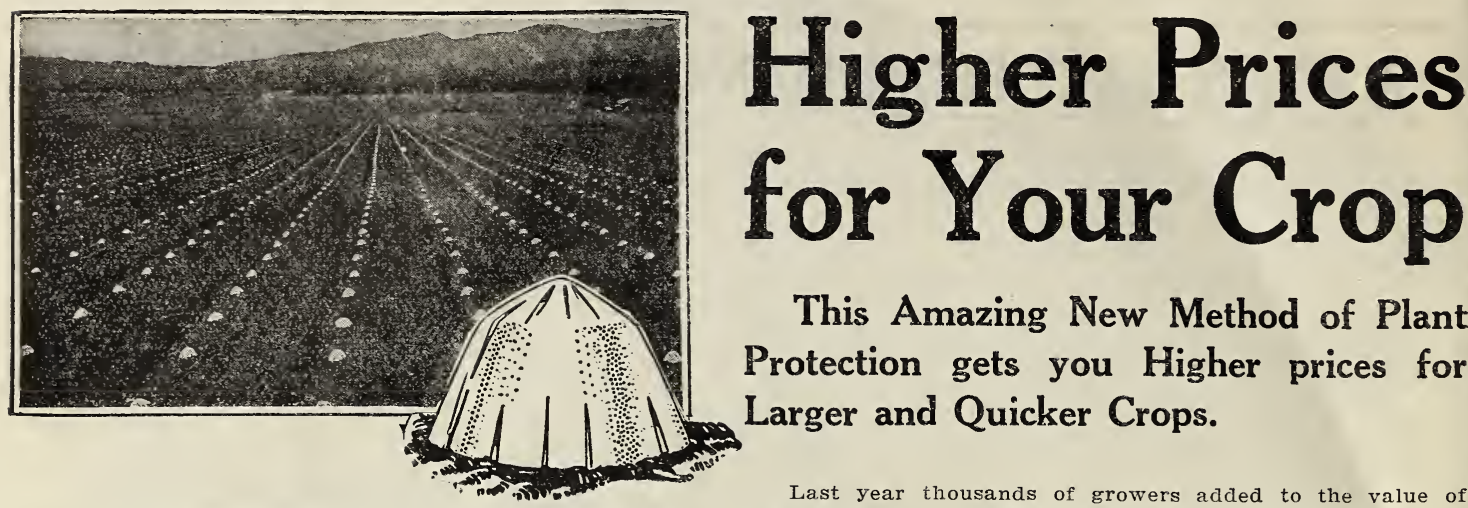

This Amazing New Method of Plant Protection gets you Higher prices for Larger and Quicker Crops.

"Hotkans" are considered by authorities as one of the greatest agricultural inventions in the past decade. Last year farmers and market gardeners in 48 states of the Union successfully used them for protecting their crops of melons, cucumbers, tomatoes, egg plant, peppers, squash, etc., against frost and for earlier crop maturity.

\section{Prices of "Hotkaps"}

50 for $\$ 1.25 ; 100$ for $\$ 2.00 ; 250$ for $\$ 4.00 ; 500$ for $\$ \% .50$, by parcel post, postpaid.

In even thousands, by express, not prepaid: 1,000 for \$11.50; 5,000 or more at $\$ 11.00$ per thousand.
Last year thousands of growers added to the value of their crops by using Germaco HOTKAPS-shown above. This remarkable invention consists of a scientifically constructed wax paper cone that you place over each plant. Thus they are miniature hot-houses that protect plants from frost, wind, rain, insects and ground crusting.

HOTKAPS not only protect plants. but make them grow hardier and faster. Thus you get a greater crop production to market earlier for higher prices!

You can add to your next year's profit with Hotkaps. They cost but a fraction over a penny each. One man can "set" 3,000 Hotkaps per day. They not only bring you higher prices, but are a method of crop insuranceagainst the danger of the elements.

"HOTKAP" SETIERS Where the Hotkaps are used in large quantities, the GERMACO HOTKAP SETTER will prove very helpful. It is a labor-saving device for setting Price, $\$ 2.50$ each, by express, not prepaid; or $\$ 3.00$, by parcel post, postpaid. We also have a more cheaply made, setter, known as the Garden Setter, which we do not recommend for the large user. It will do the same made setter, known as the Garden Setter, which we do not recommend for the small gardener to buy. We can supply the Garden Setters at Fo each, postpaid.

Special Offer 250 Hotkaps and one Garden Setter, by express, not prepaid, for $\$ 4.00$.

\section{An Odorless Fertilizer for all Growing Plants EASY TO USE IMMEDIATE RESULTS}

To get the best results from plants, either outdoors or in, you must feed them. Fertil- $X$ is a scientifically prepared, highly concentrated, complete plant food that is easy to use and sure to produce the desired results.

Fertil-X will make your flowering plants bloom earlier and hold their blossoms longer. It will make larger blossoms and more of them, and the plants more robust and thrifty.

Fertil-X will make your foliage plants quickly put on new growth; and the foliage will be of better and richer color.

Fertil-X will make vegetable crops, berry bushes and fruit trees increase production, and improve the quality of the fruits and vegetables. Fertil-X will transform your lawn from a patch of ordinary grass to a rich velvety green, and less water will be required to keep it in good condition.

good condition. for house plants, ferns, roses, and flower and vegetable gardens. Not only that, but it is odorless and has no obnoxious, messy characteristics. There is nothing disagreeable about using it.

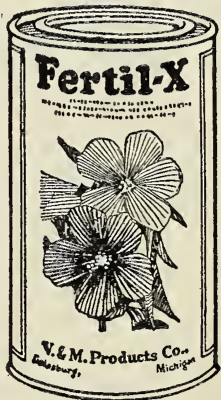

Fertil-X has a decided advantage over ordinary fertilizers in that it is so highly concentrated that only a little of it is required, thus saving the customer considerable in freight charges and time in applying. It also differs from many fertilizers in that it is not slow-acting. Fertil-X is correctly proportioned to produce satisfying results, and acts inmediately.

Unlike stable manure, Fertil-X does not carry weed seed into your soil. We might further compare it to manure with the following facts and figures:

PHOSPHORIC ACID-Fertil-X contains 300 times as much phosphorus as ordinary stable manure. Phosphorus in manures runs about onetenth of one per cent and as such is of little benefit.

POTASH-Fertil-X contains 75 times as much potash as ordinary manure. In manure the per-

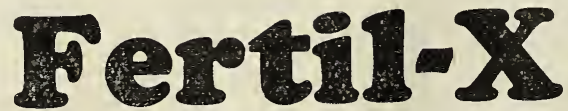

(FERTHLIZE EXTRACT) centage is about five-tenths of one per cent, which is hardly sufficient for any crop.

NITROGEN - Barnyard manure is usually composed to a large extent of straw. Straw, instead of adding nitrogen to the soil, will often take nitrogen

\section{Times as Strong as Barnyard Manure}

Garden Vegetables, 100 to $300 \mathrm{lbs}$. of Fertil-X is required per acre.

Wheat, Oats, Barley and Rye, 50 to $75 \mathrm{lbs}$. per acre.

Corn, 30 to 150 lbs. per acre.

Fruit Trees, 1 to 5 lbs. per tree.

Lawns, $1 \mathrm{lb}$. for each 250 square feet. from it. Straw in the process of decaying uses up the nitrogen that is already in the soil and leaves the soil more deficient in nitrogen than before. Fertil-X is 15 per cent pure nitrogen, which is immediately available as plant food.

Fertil-X has a guaranteed analysis of 15 per cent nitrogen, 15 per cent potash and 30 per cent phosphoric acid, all available. In other words Fertil-X is 60 per cent available and contains no filler or cheap inert matter.

PRICES OF FERTIL-X $1 / 2 \mathrm{lb}$. box (House Plant and Small Flower Garden Size). Enough for 30 to 125 10 Ib. bag (Small Lawn and Garden Size). \$3.50, delivered prepaid to any part of the United States. 


\section{Burgess' Evergreen Lawn Mixture}

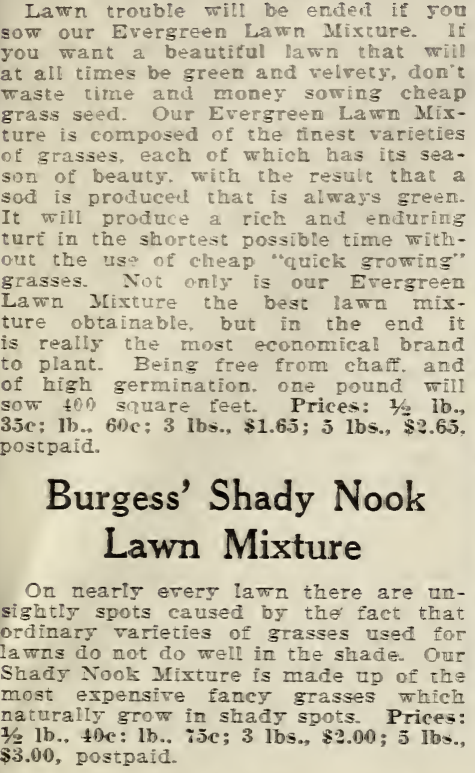

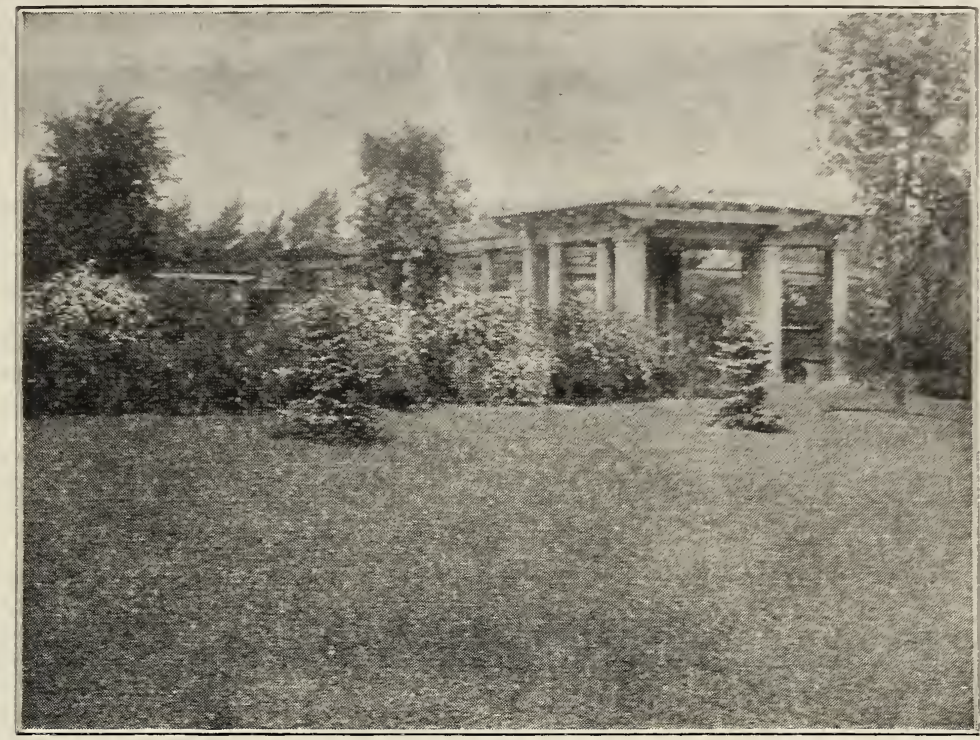

'Burges' Evergreen Lawn Mixture

\section{Burgess' Creeping Bent Grass Mixture}

\section{The Lawn Grass Which Discourages Weeds}

This is the most popular grass for golf courses and it is rapidi gaining in faror as a lawn grass, for the renson it likes an acid soil and can ba fed with acid reacting fertilizers, such as Ammonium Sulphate, the constant use of minich discourages weeds. Our Creeping Bent is a mixture of several Bent Grasses, including True Creeping
Bent, Velvet Bent and Rhode Island Bent. It is the best Bent Grass obtainable, and We consider that we are fortunate in being able to supply our customers with a sufeet. Prices: $1 / 2 \mathrm{lb}, 85 \mathrm{c} ; \mathrm{lb}, \$ 1.60 ; 3 \mathrm{lbs} ., \$ 4.65 ; 5$ lbs, $\$ \mathrm{i} .50$, postpaid.

\section{White Clover for Lawns}

We have an Extra Fancy Dwarf White Clover that is especially fine for sowing with lawn grass mixtures. This variety will retain its green appearance throughout the hottest summer, and forms a close herbage twich blends with the other grasses. For this purpose we recommend one ounce to each pound of grass seed. Pht., (about one ounce), $10 \mathrm{c} ; 1 / 4$ lb., $25 \mathrm{c} ; 1 / 2 \mathrm{lb} ., 45 \mathrm{c} ; \mathrm{lb} ., 85 \mathrm{c}$, postpaid.

Doo-Klip Fertilizer Sprayer

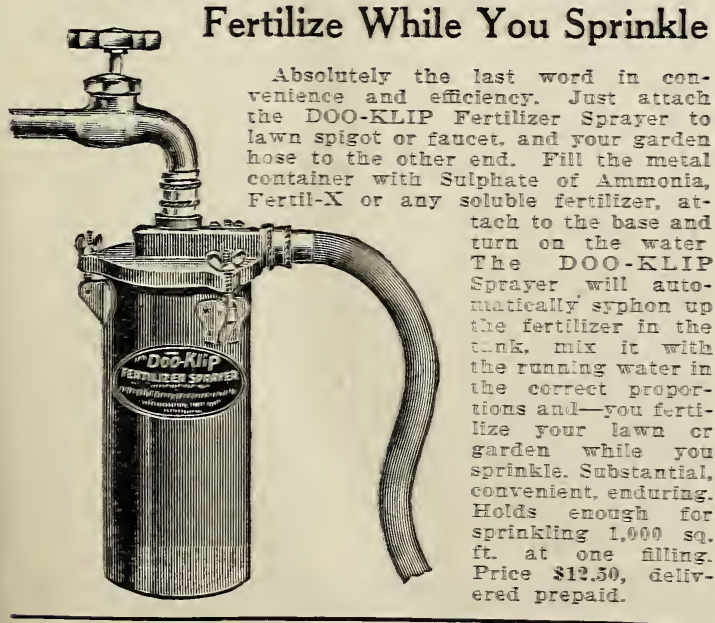

Everything in This Catalog Delivered Prepaid Cnless Otherwise Stated
Arcadian Sulphate of Ammonia

AFCIDIA STLPHATE OF AMMONIA

Which will increase the growrth of the grass so as to crom

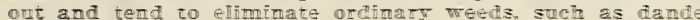

out and tend to
lion, crabgrass

use on the lawn will bring

to the growth of the grass and wath produce a

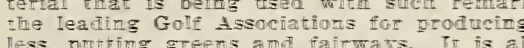

regetable and flo wer gardens, shrubs am

gen-hishlt

Arcadian contains a
manure. 10 Ibs. Wil

garden.

PRICE:

\$3.00, by express, not prepaio

SPECIAL OFFER

Targe mon th bas br treight

Wholesale Prices

For Wholesale Prices of Iamn grass page 7 .

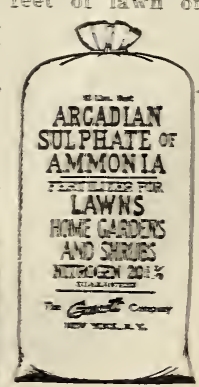




\section{Market Gardeners Wholesale Prices}

Our Market Gardeners' Wholesale Prices are very low. You can't get as good seeds anywhere for less money, or better seeds at any price. We will do our best to maintain these low prices throughout the entire season, but owing to a short crop of some varieties and possible fluctuation in prices due to an unsteady market, we can not absolutely guarantee that there will be no changes on any of the items before the season is over. Market Gardeners' Wholesale Prices are, therefore, subject to change, but we hope we will not have to change any of them, and will not unless it is absolutely necessary.

Our Market Gardeners' Wholesale Prices apply only on an order totaling ten pounds or more of seed. That does not mean that you must buy ten pounds bulk, entitles you to the Market Gardeners' Wholesale Prices given on this page and pages 77 and 78 . Don't ask us to make a shipment of less than ten pounds at these prices, as we absolutely can not do so. This is a rule that will be strictly adhered to.

Also REMEMBER, seeds sold at our Market Gardeners' Wholesale Prices are not delivered prepaid, but are sent by express, customer to pay the express charges. If it is your desire that shipment be made by parcel post, we can send that way if you will send extra for postage and packing, according to the rates on the schedule of Postage and Packing Charges as shown below. There will be no charge. however, for packing when seeds are sent by express. Only on very short hauls will there be any saving on parcel post shipments, as seeds go at second-class express rates, and with the possible exception of the lower peninsula of Michigan. northern Indiana, northern and western Ohio, northern Illinois and south-eastern Wisconsin, packages of seed weighing ten pounds or more usually go about as cheap or cheaper by express. We would almost always recommend express shipment on seeds shipped in Market Gardeners' Wholesale quantities.

\section{Postage and Packing Charges on PARCel post SHIPMENTS at}

Below we have arranged a schedule, according to States, of postage and packing charges on parcel post shipments of seeds ordered at the Market Gardeners' Wholesale Prices. This enables our customers to tell at a glance just how much it will cost them to have us send their seeds by parcel post.

\begin{tabular}{|c|c|c|c|}
\hline $\begin{array}{r}\text { Postage and } \\
\text { Packing Charge } \\
\text { per lb. }\end{array}$ & $\begin{array}{r}\text { Postage and } \\
\text { Packing Charge } \\
\text { per lb. }\end{array}$ & $\begin{array}{r}\text { Postage and } \\
\text { Packing Charge } \\
\text { per } \mathbf{l b} .\end{array}$ & $\begin{array}{r}\text { Postage and } \\
\text { Packing Charge } \\
\text { per Ib. }\end{array}$ \\
\hline Alabama ........8 $8 \mathrm{c}$ & Kansas. & Nevada & South Carolina \\
\hline Arizona $\ldots \ldots \ldots \ldots \ldots$ & Kentucky $\ldots \ldots \ldots \ldots 6$ c & New Hampshire & South Dakota. \\
\hline Arkansas $\ldots \ldots \ldots 8 c$ & Louisiana ......8 $8 \mathrm{c}$ & New Jersey .... & Tennessee ... \\
\hline California $\ldots \ldots \ldots 14 \mathrm{c}$ & Maine ........ 8c & New Mexico & Texas ...... \\
\hline Colorado $\ldots \ldots \ldots$....10 & Maryland $\ldots \ldots \ldots 6$ c & New York ..... & Utah ........ \\
\hline Connecticut $\ldots \ldots .8 \mathrm{c}$ & Massachusetts & North Carolina & Vermont $\ldots$. \\
\hline Delaware $\ldots \ldots \ldots 6$ c & Michigan ... & North Dakota. & Virginia $\ldots \ldots \ldots$ \\
\hline Florida $\ldots \ldots \ldots$ & Minnesota & Ohio ........ & $\begin{array}{l}\text { Washington ....... } \\
\text { West Virginia } \ldots \ldots 66 \mathrm{c}\end{array}$ \\
\hline Georgia $\ldots \ldots \ldots$ & Mississippi ... & Oklahoma $\ldots$. & $\begin{array}{l}\text { West Virginia } \ldots \ldots \ldots \\
\text { Wisconsin } \ldots . . . \ldots \ldots \\
\text {. }\end{array}$ \\
\hline $\begin{array}{l}\text { Idaho } \\
\text { Illinois } \ldots \ldots \ldots \ldots \ldots \ldots \text {. }\end{array}$ & Missouri $\ldots \ldots$ & Oregon ...... & Wyoming $\ldots \ldots \ldots 10 \mathrm{c}$ \\
\hline Indiana $\ldots \ldots \ldots .4 c$ & Montana .... & Pennsylvania & Canada ........15c \\
\hline wa $\ldots \ldots \ldots \ldots 6 c$ & Nebraska .......8 $8 \mathrm{c}$ & Rhode Island & \\
\hline
\end{tabular}

PEMEMMER the above charges are made only on seeds sold at Market Gardeners' Wholesale Prices and REMEMIER, sent by parcel post. There are no postage or packing charges on seeds sold at the regular retail prices quoted in this catalog.

BEAXs (Michigan Grown)

Burgess Everbearing, or Everbearing

$\mathrm{Ky}$, Tonder

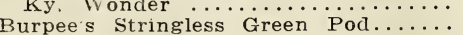

Davis White Wax ............

Early Woncier Wax......

Full Measure

Giant Stringless Green Pod...

Improved Golden Wax ..............

Improved Nichigan Pea or Navy .... .21

Pencil Pod Black Wax $\ldots \ldots \ldots \ldots \ldots . .28$

Prolific Black Wax ................26

Refugee or 1,000 to $1 \ldots \ldots \ldots \ldots \ldots$. .26

Scarlet Rumner ...................31

Wardell's Kidney Wax

Burpee's Improved Bush Lima ...

Fordhook Bush Lima

Henderson's Bush Lima

King ot the Garden Lima

Leviathan Lima

POP CORN (Hichigan Grown)

Australian Hulless

Black Beauty

Queen's Golden

White Rice
Lb. $10 \mathrm{lbs} .100 \mathrm{lbs}$.

\section{$2.20 \quad 20.00$}

$2.40 \quad 22.00$

$2.55 \quad 23.50$

2.50
3.00 23.00

3.70

$2.30 \quad 21.00$

$\begin{array}{ll}1.65 & 14.50\end{array}$

$2.40 \quad 22.00$

$2.20 \quad 20.00$

$2.20 \quad 20.00$

$2.70 \quad 25.00$

$2.70 \quad 25.00$

$2.70 \quad 25.00$

$\begin{array}{ll}2.70 & 25.00 \\ 3.20 & 30.00\end{array}$

$1.90 \quad 17.00$

$2.20 \quad 20.00$

$2.40 \quad 22.00$

$1.80 \quad 16.00$

$\begin{array}{ll}1.80 & 16.00\end{array}$

$1.80 \quad 16.00$

$1.55 \quad 13.50$
.
SWEET CORN (Michigan Grown)

De Lue's Golden Giant $\ldots \ldots \ldots \ldots \ldots \ldots . .22 \quad \begin{aligned} & 1.80 \\ & 16.00\end{aligned}$

Early Mayflower ....................... $\quad .21 \quad 1.70 \quad 15.00$

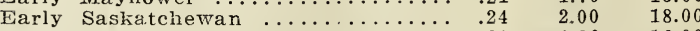

Golden Evergreen .................22 $1.80 \quad 16.00$

Golden Sunshine $\ldots \ldots \ldots \ldots \ldots \ldots \ldots \ldots, .31 \quad 2.70 \quad 25.00$

Improved Golden Bantan .............22 $.22 \quad 1.80 \quad 16.00$

Mammoth White Cory $\ldots \ldots \ldots \ldots \ldots \ldots, \quad .21 \quad 1.70 \quad 15.00$

Stowell's Evergreen ....................2 $\quad .21 \quad 1.70 \quad 15.00$

PEAS (Michigan Grown)

Alaska $\ldots \ldots \ldots \ldots \ldots \ldots \ldots \ldots \ldots \ldots, .21 \quad 1.70 \quad 15.00$

American Wonder

Burgess' Drought Proof $\ldots \ldots \ldots \ldots \ldots . .35 \quad 3.10 \quad 29.00$

Champion of England ............. .23 $\quad 1.90 \quad 17.00$

Dwarf Gray Sugar ...................26 $\quad 2.20 \quad 20.00$

Gradus .......................... $24 \quad 2.00 \quad 18.00$

Horsford's Market Garden ............. $24 \quad 24 \quad 2.00 \quad 18.00$

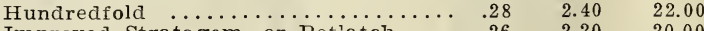

Improved Stratagem, or Potlatch $\ldots . .26 \quad .26 \quad 2.20 \quad 20.00$

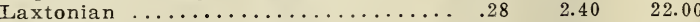

Little Marvel .......................... $\quad .26 \quad 26 \quad 2.20 \quad 20.00$

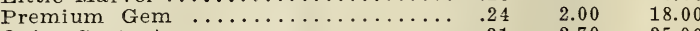

Quite Content $\ldots \ldots \ldots \ldots \ldots \ldots \ldots \ldots, .31 \quad 2.70 \quad 25.00$

Telephone $\ldots \ldots \ldots \ldots \ldots \ldots \ldots \ldots \ldots \ldots, .24 \quad 2.00 \quad 18.00$

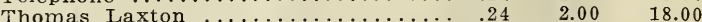

Don't Order at These Prices until you have read the above IMPORTANT NOTICE. You may order $5 \mathrm{lbs}$. or over at the $10-\mathrm{lb}$. rate; $25 \mathrm{lbs}$. or over at the $100-\mathrm{lb}$. rate. 
DO NOT ORDER at these prices until you have read the IMPORTANT NOTICE and the complete information given on page 76.

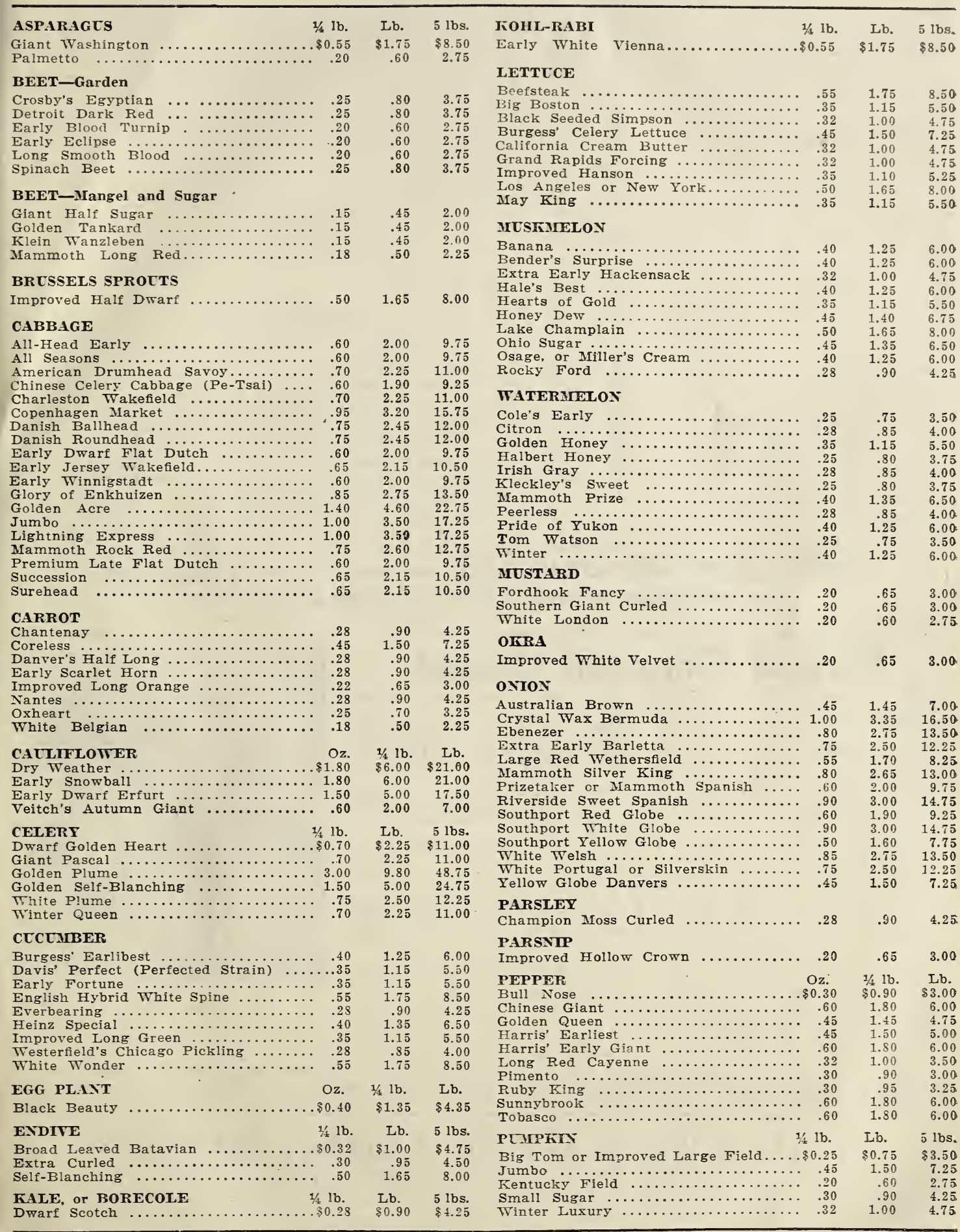

ABOVE PRICES ARE NOT PREPAID and are for quantity buyers only. See information on page 76 before ordering at these prices. 
DO NOT ORDER at these prices until you have read the IMPORTANT NOTICE and the complete information given on page 76.

\section{RADISH}

Crimson Giant

Early Bird

Early Long Scarlet Short Top

Early Scarlet Turnip

Early White Turnip

French Breakfast

Icicle

Long Black Spanish

Long White Strassburg

Saxa

Scarlet China

White Tipped Scarlet Turnip

Prize Mixture

SALSIFY

Mammoth Sandwich Island

SPINACH

Bloomscale

King of Denmark

Monstrous Viroflay

New Zealand

Victoria ...

SQUASH

Blue Hubbard

Chicago Warty Hubbard

Cocozelle

Delicious

Early White Bush

Giant Summer Crookneck

Golden Hubbard

Mammoth White Bush Scallop

True Hubbard ..........................

TOMATO (Our Select Stock)

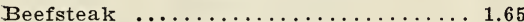

Bonny Best

Burgess' Earliest and Best

\begin{tabular}{|c|c|c|}
\hline $4 \mathrm{lb}$. & Lb. & 5 lbs. \\
\hline $\begin{array}{l}0.22 \\
. \quad .30\end{array}$ & $\begin{array}{r}90.100 \\
.90\end{array}$ & $\begin{array}{r}\$ 0.20 \\
4.25\end{array}$ \\
\hline .20 & .65 & 3.00 \\
\hline .20 & .65 & 3.00 \\
\hline .22 & .70 & 3.25 \\
\hline .20 & .65 & 3.00 \\
\hline .20 & .65 & 3.00 \\
\hline .25 & .75 & 3.50 \\
\hline .22 & .70 & 3.25 \\
\hline .35 & 1.05 & 5.00 \\
\hline .25 & .75 & 3.50 \\
\hline .22 & .70 & 3.25 \\
\hline .20 & .60 & 2.75 \\
\hline .60 & 2.00 & 9.75 \\
\hline .15 & .35 & 1.50 \\
\hline .15 & .40 & 1.75 \\
\hline .15 & .35 & 1.50 \\
\hline .25 & .75 & 3.50 \\
\hline .15 & .38 & 1.65 \\
\hline . 40 & 1.25 & 6.00 \\
\hline .40 & 1.25 & 6.00 \\
\hline .40 & 1.25 & 6.00 \\
\hline .45 & 1.40 & 6.75 \\
\hline .32 & 1.00 & 4.75 \\
\hline .32 & 1.00 & 4.75 \\
\hline .40 & 1.25 & 6.00 \\
\hline .30 & .95 & 4.50 \\
\hline .40 & 1.20 & 5.75 \\
\hline 1.6 & 5.50 & 27.25 \\
\hline .80 & 2.75 & 13.50 \\
\hline 1.00 & 3.50 & 17.25 \\
\hline
\end{tabular}

\begin{tabular}{|c|c|c|}
\hline & & \\
\hline Chalk's Early Jewel & $\$ 2.75$ & 13.50 \\
\hline Cooper's Special ... & 4.50 & 22.25 \\
\hline Dwarf Stone ... & 4.00 & 19.75 \\
\hline Earliana & & 13.50 \\
\hline en Queen & & \\
\hline June Pink & 4.50 & 22.75 \\
\hline Livingston's Globe & & 22.75 \\
\hline lobe & & \\
\hline n Wilt-Resistant ... & & \\
\hline . 1.65 & & \\
\hline … $\quad .75$ & & \\
\hline \multicolumn{3}{|l|}{ TURNIP } \\
\hline Amber Glo & 60 & \\
\hline Horn & 0 & \\
\hline Early Purple Top Milan & .80 & 75 \\
\hline y Purple Top Strap Leaf & 55 & 50 \\
\hline or Golden Ball. & 60 & 2.75 \\
\hline e Top White Globe & .60 & .75 \\
\hline White Egg & .60 & 2.75 \\
\hline \multicolumn{3}{|l|}{ RUTABAGA } \\
\hline ved Purple Top Yellow & & \\
\hline Elephant & .75 & \\
\hline Sweet Russia ........ & .65 & 3.00 \\
\hline \multicolumn{3}{|l|}{ SUNFLOWER } \\
\hline Mammoth Russian & .25 & 1.00 \\
\hline LAWN GRASS & $5 \mathrm{lb}$. & $10 \mathrm{lbs}$. \\
\hline Evergreen Lawr & $\$ 2.25$ & \\
\hline A Mixtur & 2.65 & 4.75 \\
\hline g Bent Mixture & 7.00 & 13.50 \\
\hline White Clover for Lawns ........ & 3.00 & 5.75 \\
\hline FLOWER SEEDS & $1 / 4 \mathrm{lb}$. & Lb. \\
\hline.$\$ 0.12$ & $\$ 0.35$ & $\$ 1.00$ \\
\hline Irtium, Tall Mixed & .28 & .85 \\
\hline Sweet Peas, Prize Spencer Mixed ...... $\quad .25$ & .75 & 2.50 \\
\hline Peas, Early Flo & & \\
\hline ed & & \\
\hline Sweet Peas, Standard Varieties Mixed & .28 & .8 \\
\hline
\end{tabular}

ABOVE PRICES ARE NOT PREPAID and are for quantity buyers only. See information on page 76 before ordering at these prices.

\section{Burgess' Gorgeous Cannas}

CITY OF PORTLAND. A glowing shade of pink; glossy green foliage. $3 \frac{1}{2}$ feet.

EUREKA. White flowers; rich green foliage. A beautiful variety. Height, 4 feet.

KING HUMBERT. Immense heads of orange-scarlet, Orchid-like flowers measuring 6 to 8 inches across. Large heart-shaped leaves of purple-madderbrown over bronze. Height, 5 feet.

LOUISIANA. Large Orchid-like flowers of vivid scarlet; foliage a glossy green, edged with purple. 7 feet.

MRS. A. F. COXARD. Exquisite salmon-pink flowers of the largest size; green foliage. 4 feet.

RICHARD WALLACE. Immense trusses of canary yellow flowers; bright green foliage. $4 \frac{1}{2}$ feet.

SHENANDOAH. Gorgeous, large trusses of pink flowers; foliage very beautiful, being of rich ruby red, exquisitely veined and tinted. $3 \frac{1 / 2}{2}$ feet.

THE PRESIDENT. Rich, glowing, cardinal scarlet blossoms of mammoth size; luxuriant green foliage. One of the most gorgeous of all Cannas. 5 feet. VENUS. Soft rosy-pink with a pretty mottled border of yellow. $3 \frac{1 / 2}{2}$ feet. WYOMING. Flowers a beautiful shade of deep orange; purple foliage. 7 feet.

YELLOW KING HUMBERT. Deep rich yellow, marked with contrasting crimson dots; green foliage. Very showy. 5 feet.

PRIZE MIXTURE OF CANNAS. A fine assortment of varieties in mixture at $\$ 1.50$ per dozen, postpaid.

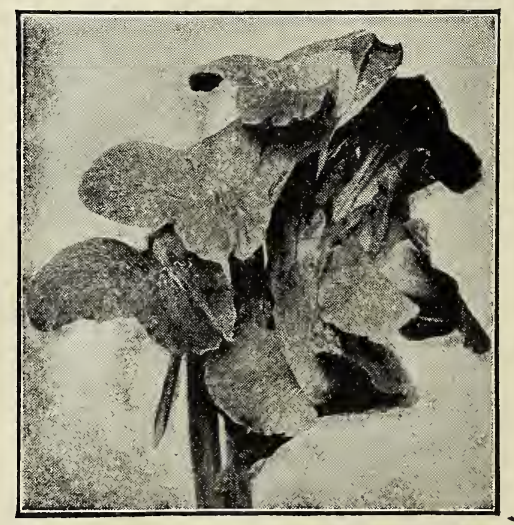

Yellow King Humbert Canna

PRICES OF CANNAS Your choice of the above-named varieties of Cannas, 25e each; 3 for 65c; 6 for $\$ 1.10$;

CANNA SEED GIANT FLOWERED MIXED. Bloom the first year from seed. Pkt., 10c.

DARK LEAVED SORTS. Finest mixture of the red and bronze-leaved varieties. Pkt., 10c.

\section{An Easy Way to Get Rid of Gophers and Moles}

One of our customers, Mrs. Earl J. Reed, South St. Paul, Minn., writes us as follows:

"It may interest you to know that last season, after having read in your catalog of planting Castor Oil Beans to keep moles out of garden, I tried them in one part of my garden which is infested with gophers of both varieties (pocket and striped). The part of the garden in which I planted Castor Oil Beans in various places had not a single gopher hill, while another lot only a short distance away was full of them. In both plots I had root vegetables planted. I

certainly intend to try this method in all my garden this year."
For further information and prices of Castor Oil Beans see page 15 of this catalog. We recommend the planting of Castor Oil Beans in vegetable and flower gardens, and the use of our Never-Fail Gopher Gun in your lawn. This Gopher and Mole Gun is described on page 73 . 


\section{INDEX TO CONTENTS}

Explanation of Table Below: Page numbers prefixed with S, Seeds; P, Plants, Bulbs or Roots.

PAGE

. S 29

Abrus

Acalypha

P $36, \$ 6$

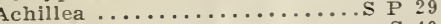

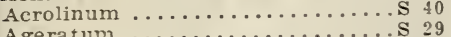

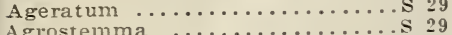

Ailanthus ................. 59

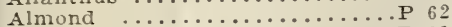

Althea .................. 62

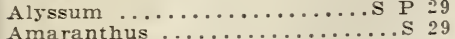

Amaranthus ....................... 62

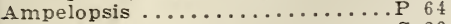

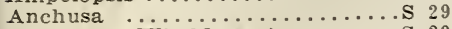

Anemone (Windflower) .......... 29

Anise ............................... 28

Anthemis (Hardy Marguerite) S P 29

Antirrhinum $\ldots \ldots \ldots \ldots \ldots \ldots$. 29

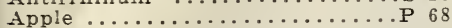

Apricot ......... Inside Front Cover

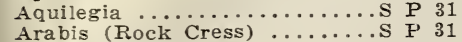

Aralia Spinosa .............. 62

Arbor Vitae ............P 60, 61

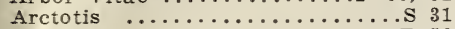

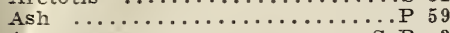

Asparagus $\ldots \ldots \ldots \ldots \ldots \ldots \ldots \ldots$ s $\mathrm{P} r$

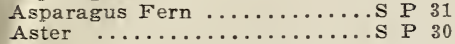

Baby's Breath (See Gypsophila) S P 41

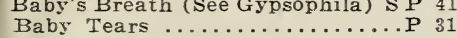
Bachelor's Button (See

Centaurea) $\ldots \ldots \ldots \ldots \ldots \ldots \ldots$. 35

Balm of Gilead ...........P 59

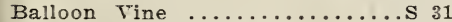

Balsam (Lady Slipper) ............. 31

Balsam Apple ................................. 31

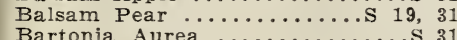

Bartonia Aurea ....................... 31

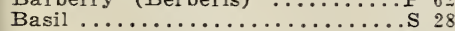

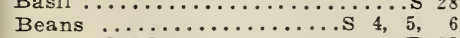

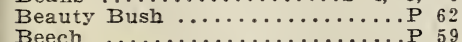

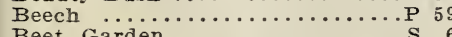

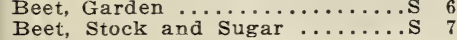

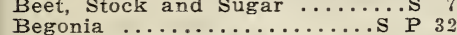

Begonia …................. P P 32

Birch ................... 59

Bittersweet (See Celastrus

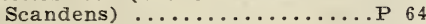

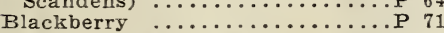

Blanket Flower (See

Gaillardia) .................. P P 40

Bleeding Heart (See Dicentra)..P 38

Blue Lace Flower .............. 31

Bocconia (See Plume Poppy)...S P 47

Boltonia ................. P 31

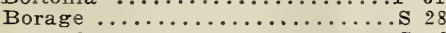

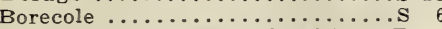

Boston Ivy (See Ampelopsis) ....P 64

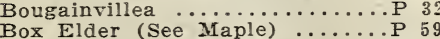

Box Elder (See Maple)
Brachycome (Swan River

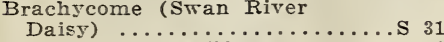

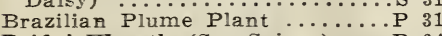

Bridal Wreath (See Spirea) ...P 64

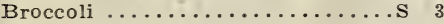

Brugmansia $\ldots \ldots \ldots \ldots \ldots \ldots \ldots \ldots \ldots . . \ldots \ldots$ P 32

Brussels sprouts .............. 6

Burning Bush (See K̈ochia) ..... 43

Buttercup (See Ranunculus) …P 48

Butterfly Bush ............ P 62

Cabbage ................... 8 ,

Cabbage $\ldots \ldots \ldots \ldots \ldots \ldots \ldots \ldots \ldots \ldots \ldots \ldots \ldots$
Cactus Caladium .............. B Back Cover

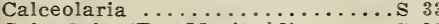

Calendula (Pot Marigold) ......... 33

Calicanthus (Sweet Scented

Shrub) $\ldots \ldots \ldots \ldots \ldots \ldots \ldots \ldots$ P 62

California Poppy ............... 39

Calliopsis $\ldots \ldots \ldots \ldots \ldots \ldots \ldots \ldots \ldots . . . \ldots \ldots$

Campanula $\ldots \ldots \ldots \ldots \ldots \ldots \ldots \ldots \ldots$. 33

Canary Bird Vine ............... 33

Candytuft $\ldots \ldots \ldots \ldots \ldots \ldots$. S 36

Canna

.S 33
PAGE

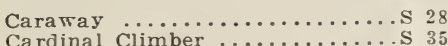

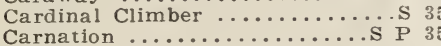

Carrot

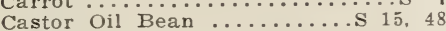

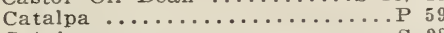

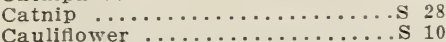

Celastrus Scandens ............. 64

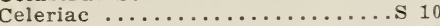

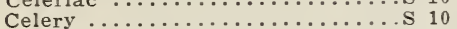

Celery-Asparagus ............. 7

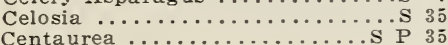

Cerastium ................ P P 39

Cherry

Chervil

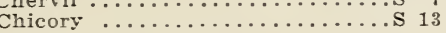

Chinese Lantern Plant .......... P P 33

Chinese Tool Flower

(See Celosia)

-S 35

Chives $\ldots . . . . . .$.

Cigar Plant

Cinnamon Vine

Cineraria

Clarkia

Cleome (Giant Spider Piant).... 35

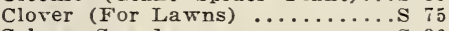

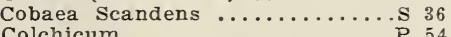

Colchicum $\ldots \ldots \ldots \ldots \ldots \ldots \ldots \ldots$. P 54

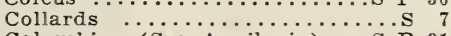

Columbine (See Aquilegia) ........................ ${ }^{7}$

Comet Plant (Acalypha

Sanderii)

Coral Berry

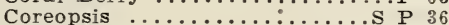

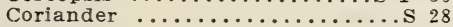

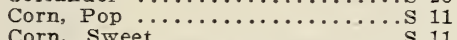

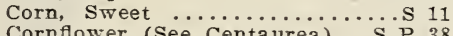

Cornflower (See Centaurea) ...S P 38

Corn Salad ........................... 10

Cosmos $\ldots \ldots \ldots \ldots \ldots \ldots \ldots \ldots \ldots \ldots$. 36

Cosmos Ornamental $\ldots \ldots \ldots \ldots \ldots$. 36 s 46

Coxcomb (See Celosia) .......... S 35

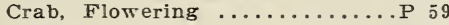

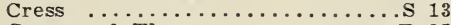

Crown of Thorns $\ldots \ldots \ldots \ldots \ldots \ldots$ P 35
Cucumber $\ldots \ldots \ldots \ldots \ldots \ldots \ldots$ s 12,13

Cucumber $\ldots \ldots \ldots \ldots \ldots \ldots \ldots \ldots$ s 12,13

Cydonia Japonica ............ 62

Cypress Vine ................. 37

Dahlia ................ 37, P 56

Daisy............. 31,39 , S P 38,48

Delphinium (Perennial Lark-

spur)

Desert Ferns

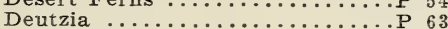

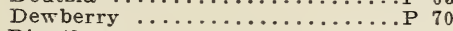

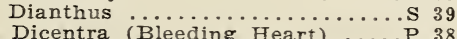

Dicentra (Bleeding Heart) ....P 38
Didiscus Coruleus (See Blue

Lace Flower) ................ 31

Digitalis ....................... P 38

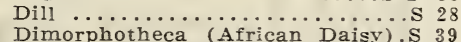

Dogrood (See Cornus) ........ P 69

Dolichos (See Hyacinth Bean).S 42

Dracaena ................. P 38

Dracocephalum (Dragon's Head)

. 39

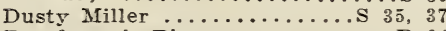

Dutchman's Pipe ............. 64

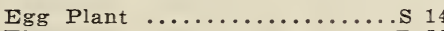

$\operatorname{Elm} \ldots \ldots \ldots \ldots \ldots \ldots \ldots \ldots \ldots \ldots \ldots$

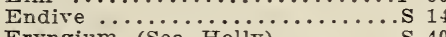

Eryngium (Sea Holly) .......... 40

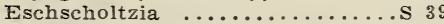

Euphorbia .................. 35 , s 50

Evening Primrose ............. 40

Evergreens ............. 60.61

Fennel

$\ldots \ldots \ldots$ S 14,28

Fertilizer $\ldots \ldots \ldots \ldots \ldots \ldots \ldots \ldots .73,74,7,75$

Fertilizer sprayer ............. 75

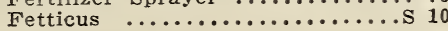

PAGE

Feverfew

Fig

Finocchio (Florence Fennel) ...P 55

Firecracker Plant ............ 39

Forget-Me-Not .............. P 44

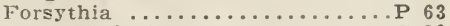

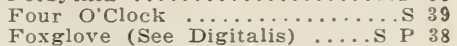

Fringe (See Digitalis)

Fuchsia

Funkia (Plantain Lily)

$\begin{array}{ll}P & 53 \\ P & 39\end{array}$

Gaillardia

Garden Heliotrope

P 58

Garden Huckleberry

Geranium

Giant Hyacinth

Ginseng

S P 40

S 14

P 41

P 11

Gladiolus ...................... 57

Globe Amaranth (Gomphrena)..S 40

Gloxinia $\ldots \ldots \ldots \ldots \ldots \ldots$. . P P 40

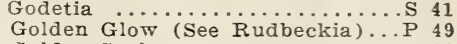

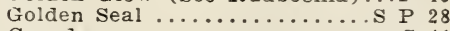

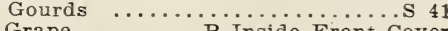

Grape .......... Inside Front Cover

Grass, For Lawns $\ldots \ldots \ldots \ldots \ldots . .$.
Grass, Ornamental $\ldots \ldots \ldots \ldots$.

Ground Almonds ............. 14

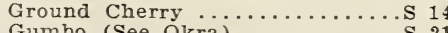

Gypsophila (Baby's Breath) ... P P 41

Helichrysum ............... 42

Heliotrope ................. P 42

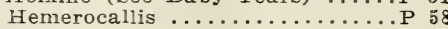

Herbs .................. ${ }^{\mathrm{P}}{ }_{28}^{58}$

Hesperis (Sweet Rocket) ........S P $P_{50}$

Hibiscus $\ldots \ldots \ldots \ldots \ldots \ldots \ldots . . \ldots$ S $\mathrm{P} 41$

Hollyhock $\ldots \ldots \ldots \ldots \ldots \ldots \ldots \ldots$. 63,64

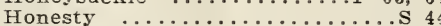

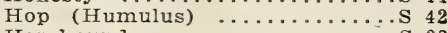

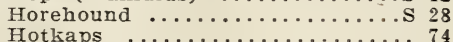

Hotkaps $\ldots \ldots \ldots \ldots \ldots \ldots \ldots \ldots \ldots . \ldots \ldots$

Hyacinthus Candicans ............. 41

Hydrangea, French or Porch....P 42

Hydrangea, Hardy $\ldots \ldots \ldots \ldots \ldots . . . \ldots \ldots$
Hyssop $\ldots \ldots \ldots \ldots \ldots \ldots$

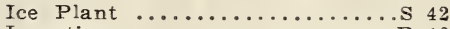

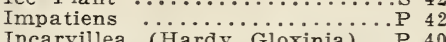

Incarvillea (Hardy Gloxinia)...P 40

Insecticides $\ldots \ldots \ldots \ldots \ldots \ldots \ldots \ldots \ldots \ldots{ }^{7}$

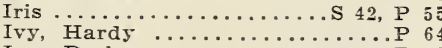

Ivy, Parlor

Japanese Quince (See Cydonia

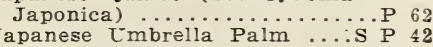

Jerusalem Cherry ............. P P 43

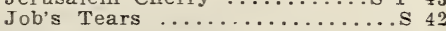

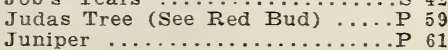

Kale (See Borecole) ............ 6

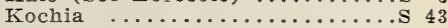

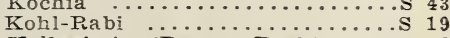

Kolkwitzia (Beauty Bush) ......P 62

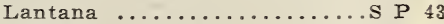

Larkspur, Annual ............. 43

Larlispur, Perennial (See

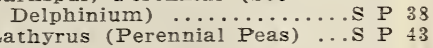

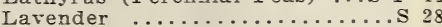

Leek ..................... 14

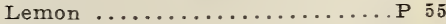

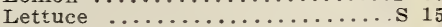

Lilac $\ldots \ldots \ldots \ldots \ldots \ldots \ldots \ldots \ldots . . \ldots \ldots$

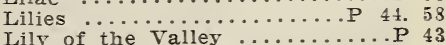

.

Linum .......................... 59

Lobelia ................. S P 43

Luffa

Lunaria

.S 44 
INDEX - Continued

\begin{tabular}{|c|c|c|c|}
\hline$P$ & $\therefore \mathrm{E}$ & \multicolumn{2}{|l|}{ PAGE: } \\
\hline Lupinus $\ldots \ldots \ldots \ldots \ldots \ldots \ldots$. 4 & & Petunia & \\
\hline Lychnis ................ P 4 & 43 & Philadelphus & \\
\hline Maderia Vine (Mignonette & & Philippine Copper Plant. & 46 \\
\hline Vine) $\ldots \ldots \ldots \ldots \ldots \ldots \ldots \ldots \ldots \ldots$ P 4 & 46 & Physalis Franchetti (See Chinese & \\
\hline Mallow Marvel $\ldots \ldots \ldots \ldots \ldots$................ 4 & 41 & Lantern Plant) $\ldots \ldots \ldots \ldots$ S $\mathbf{P} 3$ & 33 \\
\hline .......... Inside Back Cove & & Phlox $\ldots \ldots \ldots \ldots \ldots \ldots \ldots \ldots$ & 47 \\
\hline Malva (Musk Mallow) ........S 4 & 44 & Pine $\ldots \ldots \ldots \ldots \ldots \ldots \ldots \ldots \ldots$ & 61 \\
\hline $\begin{array}{l}\text { Mangel Wurzel } \ldots \ldots \ldots \ldots \ldots \ldots \text {. } \\
\text { Maple }\end{array}$ & 7 & Pinks (See Dianthus) $\ldots \ldots \ldots \ldots$ & 39 \\
\hline $\begin{array}{l}\text { Maple } \ldots \ldots \ldots \ldots \ldots \ldots \ldots \ldots \text { P } 59,8 \\
\text { Marguerite, Hardy }\end{array}$ & & Platycodon $\ldots \ldots \ldots \ldots \ldots \ldots \ldots$ s 4 & 48 \\
\hline $\begin{array}{c}\text { 1arguerite, Hardy (See } \\
\text { Anthemis) } \ldots \ldots \ldots \ldots \ldots \ldots \text {. P P } 2\end{array}$ & 29 & $\begin{array}{l}\text { Plum } \\
\text { Plume }\end{array}$ & $\begin{array}{l}70 \\
47\end{array}$ \\
\hline Marigold ................. & 44 & Poplar $\ldots \ldots \ldots \ldots \ldots \ldots \ldots \ldots \ldots$ & 59 \\
\hline 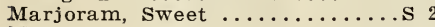 & 28 & Poppy $\ldots \ldots \ldots \ldots \ldots \ldots \ldots$ P 4 & 48 \\
\hline Marvel of Peru .............. 3 & 39 & Portulaca $\ldots \ldots \ldots \ldots \ldots \ldots \ldots \ldots \ldots \ldots$ & 46 \\
\hline Matrimony Vine $\ldots \ldots \ldots \ldots \ldots$ P 6 & 64 & Primrose $\ldots \ldots \ldots \ldots \ldots \ldots$. P 4 & 48 \\
\hline Matthiola (Evening Scented & & Privet $\ldots \ldots \ldots \ldots \ldots \ldots \ldots \ldots \ldots$ & 63 \\
\hline Stock) $\ldots \ldots \ldots \ldots \ldots \ldots \ldots$ & 44 & Prunus Pissardi $\ldots \ldots \ldots \ldots \ldots \ldots$ P 5 & 59 \\
\hline Mexican Fire Plant (Kochia)....S & 43 & Pumpkin $\ldots \ldots \ldots \ldots \ldots \ldots \ldots$ S 2 & 23 \\
\hline & 44 & Pyrethrum $\ldots \ldots \ldots \ldots \ldots \ldots$ S P 4 & 48 \\
\hline $\begin{array}{l}\text { Mimosa (Sensitive Rose) } \ldots \\
\text { Mock Orange (See }\end{array}$ & 49 & Quince $\quad \ldots$ & \\
\hline $\begin{array}{l}\text { Mock Orange (See } \\
\text { Philadelphus) }\end{array}$ & 63 & & 70 \\
\hline Mole Gun ................. & 73 & Radish & 24 \\
\hline fomordica $\ldots \ldots \ldots \ldots \ldots$ & 31 & Raspberry & 71 \\
\hline Moon Flower .............. & 44 & Ranunculus $\ldots \ldots \ldots \ldots \ldots$ P 4 & 48 \\
\hline Morning Glory ............. & 45 & $\ldots \ldots \ldots \ldots \ldots \ldots$ & 59 \\
\hline Mountain Ash ............P & 59 & Resurrection Plant ........ & 54 \\
\hline Mulberry $\quad \ldots \ldots \ldots \ldots \ldots \ldots \ldots$ & 59 & Rhubarb $\ldots \ldots \ldots \ldots \ldots \ldots$ S $\mathbf{P}_{2}$ & 25 \\
\hline Mushroom Spawn ......... & 1 & Rhus $\ldots \ldots \ldots \ldots \ldots \ldots \ldots \ldots \ldots \ldots$ & 63 \\
\hline Muskmelón $\ldots \ldots \ldots \ldots \ldots$. 16 & 17 & Ricinus $\ldots \ldots \ldots \ldots \ldots \ldots \ldots$ s 15,4 & 48 \\
\hline Mustard $\ldots \ldots \ldots \ldots \ldots \ldots$ & 19 & Rodanthe $\ldots \ldots \ldots \ldots \ldots \ldots \ldots$ & 40 \\
\hline 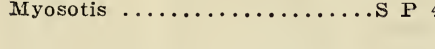 & 44 & $\begin{array}{l}\text { Roses } \ldots \ldots \ldots \ldots \ldots \ldots \text { S } 51, \text { P } 65,66,6 \\
\text { Rosemary } \ldots \ldots \ldots \ldots \ldots \ldots \ldots \ldots \ldots \text { S } 2\end{array}$ & $\begin{array}{l}67 \\
28\end{array}$ \\
\hline Nasturtium & 45 & Rose of Sharon (See Althea) ...P 6 & 62 \\
\hline Guinea Butter Vine. & 19 & Rose Tree of China......Front Co & \\
\hline icotiana $\ldots \ldots \ldots \ldots$. & 45 & Royal Purple Plant $\ldots \ldots \ldots \ldots$ P & \\
\hline Nigella & 46 & Rubber plant $\ldots \ldots \ldots \ldots \ldots$ & 48 \\
\hline Night Bloo & 42 & 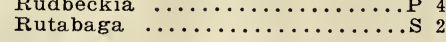 & $\begin{array}{l}49 \\
26\end{array}$ \\
\hline Oenothera (See Eve & & ..... & \\
\hline Primrose) & 4 & Salpiglossis . . & 50 \\
\hline$\ldots \ldots \ldots \ldots \ldots \ldots$ & 21 & Salsify $\ldots \ldots \ldots \ldots \ldots$ & 26 \\
\hline Oleander. & 4 & Salvia $\ldots \ldots \ldots \ldots \ldots$ & 49 \\
\hline Onion $\ldots \ldots \ldots \ldots \ldots \ldots$ s 20 , s & 21 & Scabiosa $\ldots \ldots \ldots \ldots$ & 9 \\
\hline$\because \ldots \ldots \ldots \ldots$ & 55 & Schizanthus ... & 49 \\
\hline Orange Sunberry $\ldots \ldots \ldots \ldots \ldots$ S & 21 & Sea Kale $\ldots \ldots \ldots \ldots \ldots \ldots \ldots$ & \\
\hline Oxalis $\ldots \ldots \ldots \ldots \ldots \ldots \ldots \ldots$ & & $\begin{array}{l}\text { Semesan } \\
\text { Sensitive Rose }\end{array}$ & 25 \\
\hline Palm & 47 & 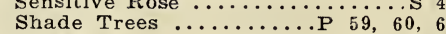 & $\begin{array}{l}49 \\
61\end{array}$ \\
\hline$\ldots \mathrm{S} \mathrm{P}$ & 46 & Shasta Daisy ... & 38 \\
\hline Parrot's Feather .......... & 46 & Shrubbery ......... & 64 \\
\hline Parsley $\quad \ldots \ldots \ldots \ldots \ldots \ldots \ldots \ldots$ & 23 & $\ldots \ldots \ldots$ s 5 & 50 \\
\hline Parsnip .... & 24 & Silk Oak Tree. & 49 \\
\hline$\ldots \ldots \ldots$ & 69 & $\ldots \ldots \ldots$ & 49 \\
\hline Peanut $\quad \ldots \ldots \ldots \ldots \ldots \ldots \ldots$. & 24 & Smoke Tree (See Fringe) $\ldots \ldots$ P 6 & 63 \\
\hline$\ldots \ldots \ldots \ldots \ldots \ldots \ldots \ldots, P$ & 69 & Snake Plant & 50 \\
\hline$\ldots \ldots \ldots \ldots \ldots \ldots \ldots \ldots \ldots$, & 22 & Snapdragon (See Antirrhinum)..S 2 & 29 \\
\hline Peat Moss $\ldots \ldots \ldots \ldots \ldots$ & 73 & $\ldots \ldots \ldots \ldots \ldots \ldots \ldots \ldots$ & 63 \\
\hline Pelargonium (Pansy Geranium) & 41 & Snowberry .. & 64 \\
\hline Peony & 58 & Snow on the Mountain & \\
\hline Pepper .... & 23 & $\ldots \ldots \ldots \ldots$ & 26 \\
\hline Periwinkle (See Vinca) ......S P & 52 & Spirea $\ldots \ldots \ldots \ldots \ldots \ldots \ldots \ldots$ P 6 & 64 \\
\hline Persimmon $\quad \ldots \ldots \ldots \ldots \ldots \ldots \ldots$ P & 59 & Spruce $\ldots \ldots \ldots \ldots \ldots \ldots \ldots \ldots$ P 6 & 61 \\
\hline
\end{tabular}

Pquash $\ldots \ldots \ldots \ldots \ldots \ldots \ldots \ldots \ldots \ldots \ldots \ldots$ PAGE

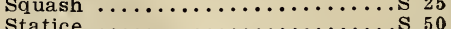

Statice $\ldots \ldots \ldots \ldots \ldots \ldots \ldots \ldots \ldots \ldots$
Stocks

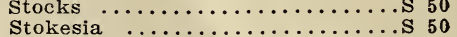

Strawflowers (See Helichrysum).S 42

Strawberry $\ldots \ldots \ldots \ldots \ldots \ldots \ldots$ P 72

Sumac (See Rhus) ........... 63

Summer Savory $\ldots \ldots \ldots \ldots \ldots \ldots \ldots \ldots \ldots \ldots \ldots \ldots$ s 28

Sweet Marjoram $\ldots \ldots \ldots \ldots \ldots \ldots \ldots$. 28

Sunflower $\ldots \ldots \ldots \ldots \ldots \ldots \ldots \ldots \ldots \ldots \ldots$ s 50

Sweet Peas ................. 51

Sweet Peas, Perennial (See

Lathyrus) $\ldots \ldots \ldots \ldots \ldots \ldots \ldots \ldots$ P 43

Sweet Rocket .............. S 50

Sweet Sultan (See Centaurea)..... 35 Sweet William $\ldots \ldots \ldots \ldots \ldots \ldots$ s $P$ P 50

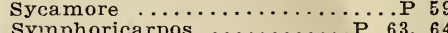
Syringa (See Philadelphus) ...P 63

Tamarix ................ 64 Thyme $\ldots \ldots \ldots \ldots \ldots \ldots \ldots \ldots \ldots \ldots \ldots$ S 28

Tobacco $\ldots \ldots \ldots \ldots \ldots \ldots \ldots \ldots$. 28 Tomato .....27, Inside Back Cover Tritoma (Torch Lily)..........S P 52 Trumpet Vine ............... 44 Tuberose $\ldots \ldots \ldots \ldots \ldots \ldots \ldots \ldots \ldots \ldots \ldots \ldots \ldots \ldots$ P 54 Tulip Tree ............... 59

Turnip ................. 26

Valeriana .................. 52 Vegetable Oyster (See Salsify)..S 26 Verbena Veronica $\ldots \ldots \ldots \ldots \ldots \ldots \ldots \ldots \ldots \ldots$ s P 52 Viburnum (See Snowball) ......... P 63 Vinca $\ldots \ldots \ldots \ldots \ldots \ldots \ldots$ S P 52 Vine Peach $\ldots \ldots \ldots \ldots \ldots \ldots \ldots$. S 17

Viola $\ldots \ldots \ldots \ldots \ldots \ldots \ldots \ldots \ldots$ s P 52

Violet $\ldots \ldots \ldots \ldots \ldots \ldots \ldots \ldots$ S P 52 Virginia Creeper (See

Ampelopsis) $\ldots \ldots \ldots \ldots \ldots \ldots$. P 64 Virginia Stocks $\ldots \ldots \ldots \ldots \ldots \ldots$. 52

Wallfiower $\ldots \ldots \ldots \ldots \ldots \ldots \ldots$. S 53 Walnut $\ldots \ldots \ldots \ldots \ldots \ldots \ldots \ldots$ P 59 Wandering Jew $\ldots \ldots \ldots \ldots \ldots \ldots$ P 52 Water Fern $\ldots \ldots \ldots \ldots \ldots \ldots \ldots \ldots, P$ P 54 Water Hyacinth $. \ldots \ldots \ldots \ldots \ldots \ldots . P$ P 53

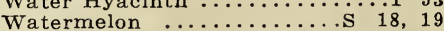
Inside Back Cover Wax Plant ................. P 53 Weather Plant (See Weed Killer $\ldots \ldots \ldots \ldots \ldots \ldots \ldots$ P 64

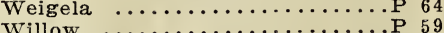

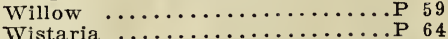
Wormwood $\ldots \ldots \ldots \ldots \ldots \ldots \ldots$. 28 Xeranthemum .............. s 40

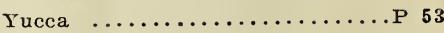

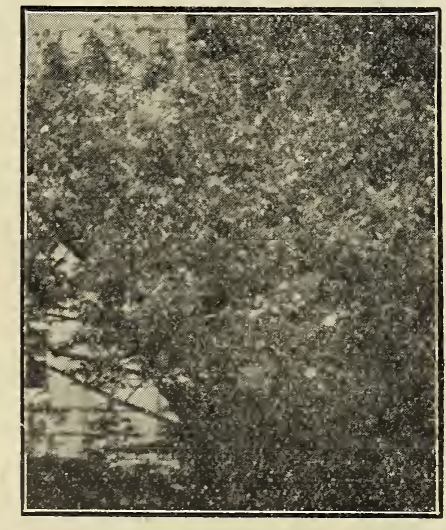

\section{Red-Leaved Japanese Maples}

\section{Rare Trees at Bargain Prices}

We have the genuine Blood Red Japanese Maples, which are so much sought after for specimen and group ornamental use. These trees are of dwarf habit, usually attaining a height of ten or twelve feet at maturity. The foliage is of the deepest rich blood red. They are very graceful and may be treated as small trees or clumped like shrubbery, and are most gorgeous when planted in combination with evergreens or other green foliage plants. Don't pay ten or fifteen dollars each for small sizes of these trees or twenty-five to fifty dollars for larger ones, when we can supply you with select plants, $1 \frac{1}{2}$ to 2 feet high, at only $\$ 6.00$ each, or in lots of three or more at $\$ 5.00$ each, delivered to you prepaid. 


\title{
Pride of Yukon
}

Ripe Watermelons in 65 Days

Not only is the Pride of Fukon the earliest Watermelon known, but it is unsurpassed for sweetness and yuality: entirely free from stringiness, and fairly melts in your mouth. Fruits are of at tractive appearance; medium in size, seldom exceed is to 20 pounds in 11 eight, averaging 10 to 15 pounds; flesh brigh scarlet. Hardy, vigorous and remaris ably productive. The best for extra early planting. especially adapted to Northern localities where the season is short. but does well in all sections the country and has created a sensation wherever grown. While it is not an extra good shipper. it is a wonderful melon for the home garden and a gold mine for the market gardener. Pkt. $10 \mathrm{c}$; oz., 15c; 1/4 lb., 45e; lb., \$1.50, postpaid.

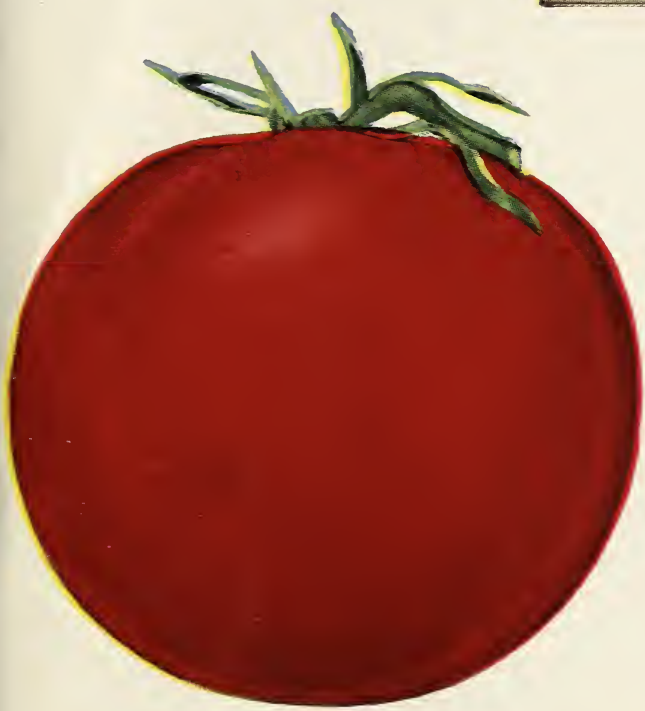

I'ride of Iukon

\section{Burgess' Earliest and Best} The Earliest and Best Tomato on Earth

\begin{abstract}
Burgess' Earliest and Best Tomato is the earliest and best variety grown. Not only will it produce large, beautiful solid shipping Tomatoes earlier than any other rariety, but it produces the most perfect High Crown Tomatoes ever grown, and entirely free from core. No cripples, no scalds, no blight, no cracked, no wrinkled, no one-sided, uneven, scarred fruit and when dead ripe they will not burst.

Not only is it the most beautiful bright red Tomato you ever saw, but it also has the finest flavor.

A marrelous stem setter; often ten fruits in first cluster, all solid and meaty, and with fewer seeds than most varieries.

It has just enough foliage- - will stand plenty of manuring without going to vine.

It is the most perfect shipping Tomato ever grown.

Being such a tremendous vielder, it can be gathered in onehalf the time of any other Tomato. and peelers can prepare three bushels to one bushel of any other rariety.

It is of the John Baer trpe, and might be termed an extra-early improved strain of that variets. On our Michigan seed farms it ripens fully two weeks earlier than the much advertised Burbank Tomato, and so much better that for quality there is no comparison. If you can grow but one variety, let that one be Burgess' Earliest and Best. Pkt., 10c; 3 pkts., 25c; $0 \mathrm{z} ., 50 \mathrm{c} ; 1 / \frac{\mathrm{k}}{\mathrm{k}} 1 \mathrm{~b} ., \$ 1.50 ; 1 \mathrm{~b} ., \$ 5.00$, postpaid.
\end{abstract}

Burgess' Earliest and Best Tomato

\section{Mammoth Mallow Marvels \$1.50}

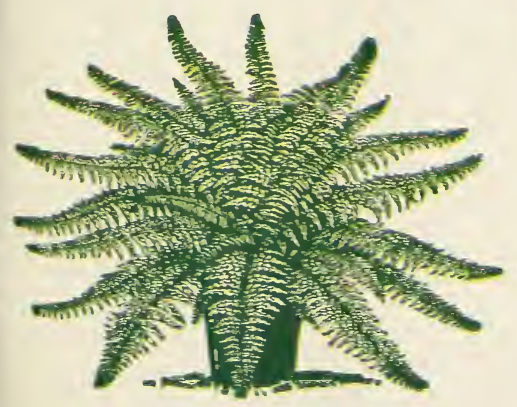

\section{Beautiful Ferns}

Nothing makes more desirable house plants than a few choice ferns and rare fern-leaf foliage plants. Send today for this grand collection of plants. Ferns need but little care, live indefinitely and grow larger and more beautiful each vear. Our collection contains the leading and most choice rarieties, such as Ostrich Plume, Rooserelt, Teddy Junior, Boston. Whitmanii. Asparagus Sprengeri (Emerald Feather). Asparagus Plumosus (Lace Fern), Sword, Staghorn, Maiden Hair, Sweet Fern, Moss Fern, etc.

Send 35c today and we will deliver to you by parcel post, postpaid, three choice plants, each different (our selection from the above varieties), and guarantee them to reach you in good growing condition.
Mallow Marrels are a wonderfully improved form of our greatly admired 12 inches in diameter, have been dereloped. A robust type of upright habit, growing from 4 to 7 abundance of flowers in all shades of crimson. pink and white. These plants can be highly recommended positions, having the same vigor in dry and wet ground and are as hardy as an oak. Bloom continually from July until October. Our field grown plants are blooming size (will blossom this year), and are mixture of colors we hare seen. 20c each; 3 for $50 \mathrm{c}$; 12 for $\$ 1.50$; postpaid.

READ OUR
GUARANTEE
ON PAGE 1

READ OUR GUARANTEE ON PAGE 1 

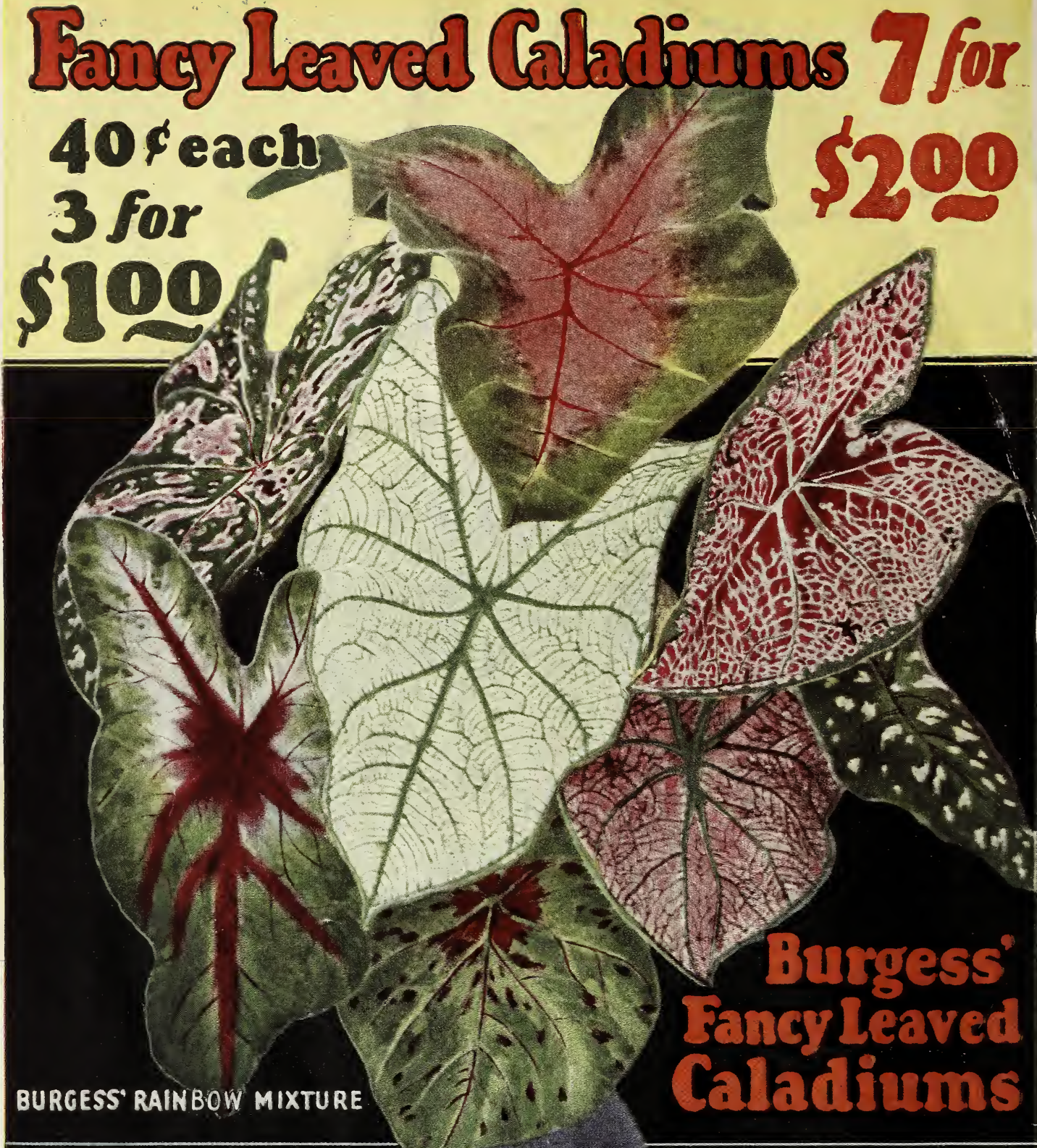

No other foliage plant equals the Fancy Leaved Caladiums in rich and gorgeous, yet soft coloring. Wherever high-class decorations are required, these plants are indispensable. When grown in pots, they may be used in the conservatory or the house with equal satisfaction. For table decorations, for window boxes, for jardinieres, and for enlivening groups of palms or ferns, they are most serviceable. They are quite as desirable for bedding purposes, and while they do their best in shady or semi-shady positions, they will do well in the sunniest situations if well watered and sheltered from strong winds.

Our collection consists of fifty varieties. The above photographic reproduction in natural colors shows eight of our fifty varieties. The other forty-two are just as beautiful as these.

\section{Burgess Seed and Plant Co., Galesbung.Nich.}

